\title{
A felsőoktatási mobilitást
}

akadályozó és

\section{ösztönző tényezők Magyarországon}

1. kötet

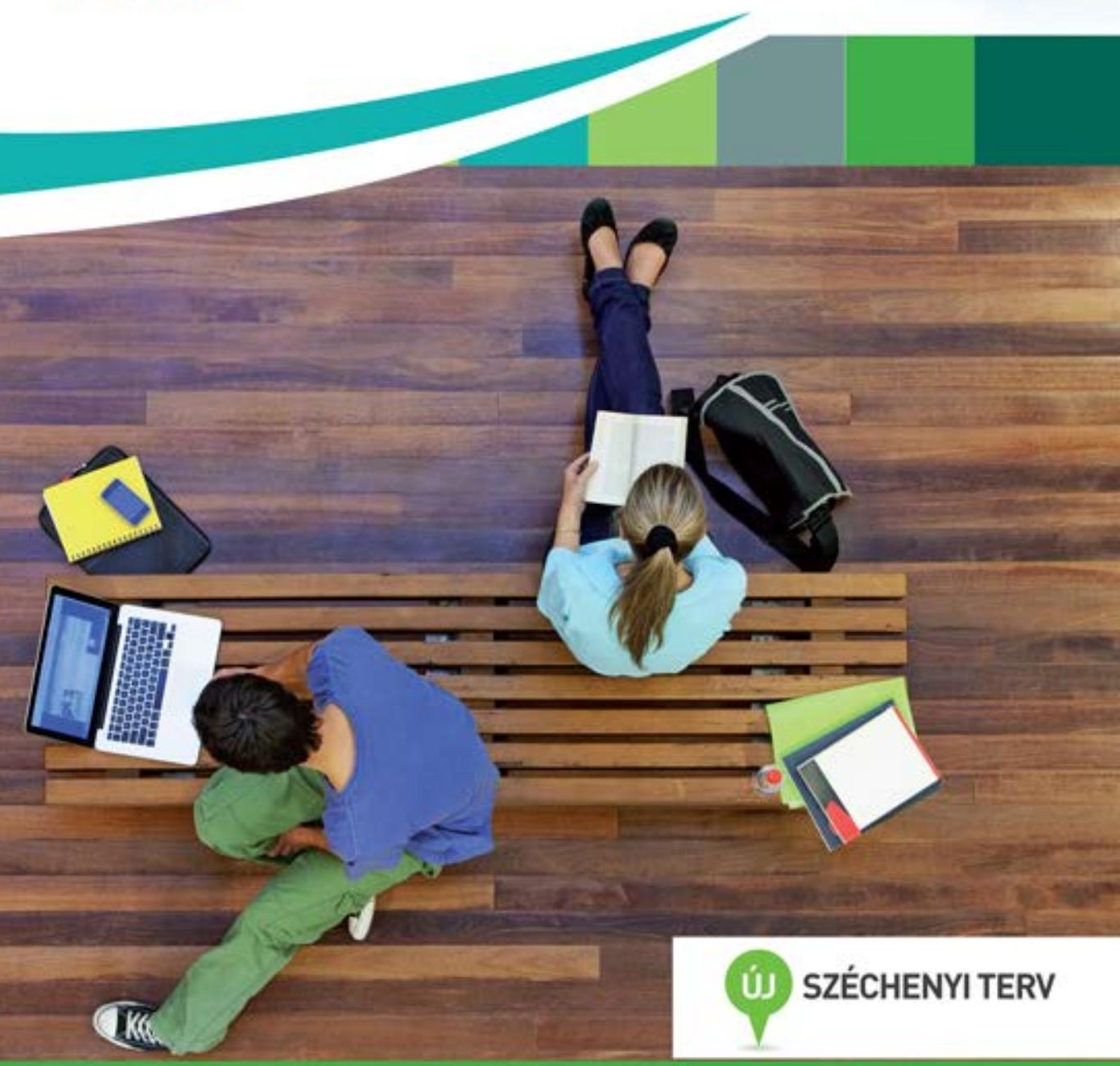





\section{Impresszum}

Felelös szerkesztö: Bokodi Szabolcs

Szerkesztők: Fekete Zsófia, Kisbáró Edina, Mester-Takács Tímea, Mészáros Gabriella

Kiadványszerkesztő: Csordás Kata

A kötet szerzói: Berács József egyetemi tanár, Bander Katalin PhD hallgató, Hubert József PhD hallgató, Nagy Gábor doktorjelölt, Temesi József egyetemi tanár

Kiadja: Tempus Közalapítvány, 2014

A kiadásért felel: Tordai Péter, igazgató

Nyomdai kivitelezés: Komáromi Nyomda és Kiadó Kft.

Tempus Közalapítvány

1093 Budapest, Lónyay u. 31.

Postacím: 1438 Budapest 70, Pf. 508.

Infóvonal: (061) 2371320

E-mail:info@tpf.hu

Internet: www.tka.hu

www.campuhungary.hu/tempus

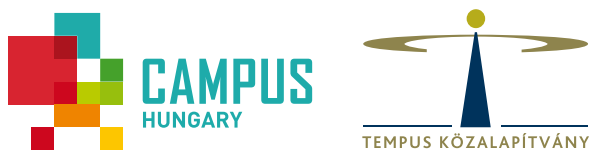




\section{Tartalomjegyzék}

ELŐSZÓ

A magyar felsőoktatás nemzetközi versenyképességének néhány tényezője a globális és regionális mobilitás tükrében

Mobilitást akadályozó és ösztönző intézményi tényezők 53

Kreditrendszerek és alkalmazásuk Európában és a felsőoktatás globális terében 115 


\section{ELŐSZÓ}

A Tempus Közalapítvány által kezelt európai, regionális és nemzeti felsőoktatási programok és az általa végrehajtott projektek szorosan kötődnek az Európai Unió Európa 2020 stratégiájához, a Felsőoktatás Modernizációs Agendájához, valamint az Európai Felsőoktatási Térség elmélyítéséhez, megvalósításához.

Tevékenységünk középpontjában a magyar felsőoktatás nemzetköziesedésének támogatása áll, és alapvetően három, egymással szorosan összefüggő szinten fejti ki a hatását: a szakpolitika, az intézmények és az egyének támogatása a következő programok segítségével: Erasmus+ (korábbi LLP/Erasmus, Erasmus Mundus, Tempus és Bologna tanácsadói hálózat), CEEPUS, valamint a Strukturális Alapokból finanszírozott Campus Hungary projektek. A programok többségét a Közalapítvány több mint egy évtizede koordinálja, míg a Campus Hungary projektek 2012-től egészítik ki a Közalapítvány nemzetköziesedést támogató tevékenységét.

A három szint közül az egyének támogatásának keretében a Közalapítvány elsősorban a hallgatók és doktoranduszok külföldi mobilitását (tanulmányi részképzését, szakmai gyakorlatát, nyári egyetemen, intenzív programon való részvételét) támogatja, mellyel hozzájárul a hallgatók kompetenciafejlesztéséhez, valamint a leendő diplomások foglalkoztathatóságához.

A hallgatókon, doktoranduszokon kívül a Közalapítvány ösztöndíjakat kínál az oktatóknak és a felsőoktatási intézmények alkalmazottainak is (oktatási tevékenységre, nemzetközi kapcsolatok bövitésére, tapasztalatszerzésre, projektek előkészitésére), mely a humánerőforrás-fejlesztésen túl nagymértékben hozzájárul az intézmények kapacitásának bővítéséhez, nemzetközi beágyazottságuk, valamint versenyképességük növeléséhez.

Az egyéni ösztöndíjak közvetetten hatással vannak a hazai intézmények fejlesztésére, hiszen a Közalapítvány által hagyományosan kezelt programok intézményekhez kötött, kétoldalú mobilitást folytatnak le, így a kiutazók helyére külföldi hallgatók, oktatók érkeznek, mellyel összefüggésben a hazai intézmények idegen nyelvü kurzusaik fejlesztésén túl, a hallgatói szolgáltatásokat, adminisztrációt is fejlesztik. Másrészt a visszatérő oktatók és felsőoktatási alkalmazottak oktatási-kutatási, irányítási, oktatásszervezési és szolgáltatásnyújtási innovációkat hoznak haza, melyek beépülhetnek a magyar intézmény működésébe. Hasonlóképpen fontos szerepe van az egyéni mobilitásnak abban, hogy a magyarországi jó példákat, innovációkat megosszák Európán belül és azon kívül is.

A Közalapítvány maga is részt vesz olyan felsőoktatási projektekben, amelyek a szektor modernizálását tűzték ki célul. Fókuszunk a hazai felsőoktatási intézmények regionális és Európán kívüli kapcsolatainak bővítése, így a hazai felsőoktatás láthatóságának javítása volt. Egyben a magyar egyetemek és főiskolák felkészítése a 2014-től kezdődő új programszakaszra, az Erasmus+ programra, melynek egyik fontos jellemzője a nyitás az Európán kívüli felsőoktatás felé.

Az egyéni mobilitáson és intézményfejlesztésen túl a Közalapítvány a programok megvalósításával kapcsolatos tapasztalataival, a fejlesztési területeket vizsgáló kutatásokkal és egy 57 országra kiterjedő szakértő hálózat magyar csoportjának működtetésével is támogatja a hazai és az európai szakpolitikák összekapcsolását.

A jelenlegi két kutatási kötet a fenti szempontok figyelembevételével folytatja a Tempus Közalapítvány kutatási tevékenységét és jól illeszkedik a 2008-ban megkezdett Bologna füzetek sorozathoz. A most megjelenő kötetek közül az első rendszerszinten vizsgálja a magyar felsőoktatás versenyképességét, illetve elemzi az egyik legjelentősebb mobilitást támogató rendszert, az ECTS-t. A második kötet már az intézményi tényezőket veszi vizsgálat alá, és egyéni ösztöndíjas szinten is kísérletet tesz a mobilitás alatt tapasztalható kompetenciafejlődésnek, valamint a mobilitással kapcsolatos elégedettségnek leírására. 


\section{A magyar felsőoktatás nemzetközi versenyképességének néhány tényezơje a globális és regionális mobilitás tükrében}

Kutatási tanulmány

\section{Készítette:}

Berács József egyetemi tanár, az MTA doktora, témavezető

Bander Katalin PhD hallgató

Hubert József PhD hallgató

Nagy Gábor doktorjelölt

Adatgyüjtésben közremüködött:

Bellér Anna MA hallgató

Budapesti Corvinus Egyetem Nemzetközi Felsőoktatási Kutatások Központja

A kutatás a TÁMOP-4.2.4.B/1-11/1-2012-0001 projekt keretében valósult meg.

„Összegző tanulmány és piackutatás a magyar felsőoktatás versenyképességéről, pozíciójáról a felsőoktatási mezőnyben" 2013. március, BCE-NFKK, Budapest címü, a Tempus Közalapítvány megbízásából készült tanulmány rövidített, szerkesztett változata. 


\section{Bevezetés és összefoglaló}

A 21. század a tudás és az információ százada, amikor a logisztikai, közlekedési rendszerek fejlettsége rendkívül vonzóvá és megvalósíthatóvá teszi a munkaerő és a diákok szabad áramlását. Ez utóbbi egyrészt nagy kockázat a befelé forduló felsőoktatási rendszerrel rendelkező országok számára, másrészt óriási lehetőség a világra nyitott, a globális versenyben is helytállni képes oktatási intézményeknek, illetve azok klasztereinek.

A fejlődő országok gazdasági átmenetével foglalkozó Európai Újjáépítési és Fejlesztési Bank (EBRD) által készített tanulmányok egyértelműen az exportfejlesztést (2010) és a határokon átívelő integrációt (2012) fogalmazták meg, mint az átmeneti országok stratégiai kitörési pontjait a válságból, amelyek a felzárkózást biztosító gazdasági növekedés elindítói lehetnek. Az oktatás és kiemelten a felsőoktatás önmagában véve is alanya lehet egy exportfejlesztési stratégiának, de ez a stratégia a világra nyitott, kimüvelt emberfők termelésével az egész gazdaság felzárkózásának egyetlen záloga, miként ezt a feltörekvő ázsiai országok vagy a fejlett skandináv államok példája bizonyítja.

A nemzetközi hallgatói áramlás sokoldalú bemutatásával amellett érvel a tanulmány, hogy a demográfiai csökkenés, a finanszírozási nehézségek és a külföldi egyetemek vonzereje miatt a 2012/13as tanévben még 310000 fős magyar egyetemi hallgatói létszám 2020-ra 270000 före fog csökkenni, akik közül szerencsés esetben 10 000, kevésbé szerencsés esetben 5000 magyar hallgató folyamatosan külföldön lesz részképzésen. A 2012/13-as tanévben a felsőoktatásba beiratkozott 330000 hallgatóból kb. 21000 külföldi hallgató tanul diplomáért, míg egyidejüleg kb. 2000 külföldi diák tanul részképzésen Magyarországon. Erőteljes kormányzati és intézményi stratégiai váltás következtében 2020-ban 60000 külföldi hallgató biztosítaná, hogy a magyar felsőoktatás, mint iparág megőrizze azt a szerepét, amelyet mindezidáig betöltött. Becslésünk szerint a javasolt létszámnövekedés 4000 új munkahelyet teremtene a felsőoktatásban (illetve tartana meg), és legalább 4000 új munkahelyet teremtene a kiszolgáló szektorban, az egyetemi városok munkaerőhelyzetében nem elhanyagolható nagyságrendet jelentve.

Az eddigi trend folytatása a 2011/12-es tanév 20000 körüli diplomát szerezni kívánó külföldi hallgatói létszámának 30000 főre történő emelkedését sejteti a vizsgált időszakban. Az EU célkitűzése, miszerint a végzett hallgatók $20 \%$-a rendelkezzen legalább egy félévnyi külföldön töltött tanulmányi idővel, a kölcsönösség alapján azt követelné meg, hogy 2020-ban legalább 10000 külföldi cserehallgató tanuljon Magyarországon egy időpontban.

A diák mobilitás nemzetközi trendjei azt mutatják, hogy a külföldi hallgatók száma 2010-ben elérte a 4 milliót, 10 év alatt megduplázódott (IIE becslés). A vezető fogadó ország továbbra is az USA, és az angolszász országok járnak az élen a külföldi hallgatók arányában. Ausztrália, Egyesült Királyság, Új-Zéland kormányai stratégiai ágazatnak tekintik a felsőoktatást és az abból származó jövedelmet. Említésre méltó, hogy Kína is bekerült a fogadó országok élmezőnyébe. A küldő országok között Kína és az ázsiai országok állnak az élen, különösen az új belépő hallgatók esetében. A magyar lehetőségek szempontjából is fontos trend Szaúd-Arábia, Vietnám és Törökország bekerülése a vezető 10 ország közé.

Ami a magyarországi trendeket illeti, a bejövő hallgatók 42\%-a még mindig a szomszédos országokból érkezik, de növekszik, és már egyötödöt tesz ki Ázsia aránya. Afrika csak 3,6\%-os részesedésében Nigéria szerepe meghatározó. A fizetős hallgatók döntő része az orvosi képzést választja, ahol a nyugat-európai (elsősorban német) hallgatók dominálnak, de sokan érkeznek Iránból és Izraelből is. Legnagyobb lemaradást a hatalmas kínai piac kiaknázatlansága jelenti, illetve a dinamikus vietnámi piacon lehetne megtöbbszörözni a részesedésünket, ha átfogó stratégia készülne.

A Campus Hungary program 2012-es meghirdetése, a megvalósíthatósági tanulmány elkészítése és az 5 milliárd forintos mobilitási, fejlesztési költségvetés (uniós forrásból) való biztosítása áttörést ígér a 
nemzetközivé válás terén. Ugyanakkor a felsőoktatási intézmények 2012-ben elkészített intézményfejlesztési terveinek (IFT) áttanulmányozása alapján arra a megállapításra jutottunk, hogy ezekben a dokumentumokban nem jelenik meg hatásosan, operativan a külföldi terjeszkedés, az ebból származó bevétel, illetve ennek minőségfejlesztő hatása. Még azok az intézmények is, amelyek élen járnak a külföldi fizetős hallgatók fogadásában (Debreceni Egyetem, Szegedi Tudományegyetem, Pécsi Tudományegyetem, Semmelweis Egyetem), egyetlen adatot sem közölnek arról, hogy mennyi bevétel származik exportból, illetve hogy ezt milyen régióból és milyen mértékben kívánják növelni. A Budapesti Műszaki és Gazdaságtudományi Egyetem honlapja (Tények és mutatószámok) tartalmaz egyedül adatot erre vonatkozóan, ahol 602 millióról 454 millió forintra csökkent 4 év alatt, 2011-re az idegen nyelven folyó képzés tandíjbevétele. Ezt a negatív trendet a brazil kormányprogram keretében érkező hallgatók tudják megfordítani.

Ahhoz, hogy a korábban jelzett stratégiai áttörés megvalósuljon, mind kormányzati, mind intézményi szinten összehangolt piaci, marketing akciókra van szükség. Más ágazatokhoz (pl. turizmus, agrárgazdaság, stb.) hasonlóan marketingstratégiát kell kidolgozni, amely megjelöli a növekedési potenciált hordozó országokat (lásd Kína, Vietnám, Szaúd-Arábia, Nigéria, Törökország, FÁK országok, stb.) és az elérésükhöz szükséges eszközöket. A nemzetközi diákvásárokon való részvétel, a külügyi és kulturális szervezetek bekapcsolása, a Bevándorlási Hivatal megfelelő tájékoztatása, egy hatékony ügynöki rendszer működtetése, a közösségi marketing eszközök bevetése (lásd pl. a DAAD gyakorlatát), megfelelő tájékoztató anyagok készítése, stb. csak akkor lehet hatékony, ha az intézmények küldetésükből fakadónak tekintik a nemzetközi piacra jutást is.

\section{Nemzetközi tendenciák}

\subsection{A nemzetközivé válás motivációi és a főbb regionális csoportok trendjei a külföldi hallgatók fogadásában}

Jogosan tehető fel a kérdés, hogy miért van szükség nemzetköziesedésre, kinek jó ez? Mindnyájunknak megvannak a válaszai, mint például a közgazdászoké, akik a nemzetközi kereskedelem komparatív előnyre építő stratégiája alapján a gazdasági növekedés forrását látják benne. A Nemzetközi Oktatás Európai Társaságának (EAIE) egyik kiadványa (Van Gaalen 2010), amely a minőségbiztosítást és a nemzetköziséget vizsgálta, táblázatba foglalta, hogy makro- és mikroszinten milyen célkitüzések fogalmazhatók meg. Miután a társaság kiemelten a diákok mobilitásával foglalkozik, ezért a célok megvalósítását szolgáló eszközök/stratégiák, valamint a nemzetköziesedés eredményei is ebben a relációban jelennek meg (2.1. táblázat). Feltételezzük, hogy az egyén és a társadalom is jobban jár, ha nemzetközi kitekintésre tesz szert. Természetesen ennek a nézetnek is vannak ellenzői és az a kérdés is felvethető, hogy van-e a nemzetközivé válásnak valamilyen optimális szintje, amely után már nem célszerű ezt tovább fokozni. Például az orvosképzésben már mind a négy magyar egyetemen meghaladja a külföldi hallgatók aránya az 50\%-ot. Kell-e ezt még tovább növelni? Választ a következő fejezetben adunk. 
1. táblázat: A nemzetközivé válás motivációi és stratégiái

\begin{tabular}{|l|l|l|l|}
\hline Szintjei & Célkitüzések & $\begin{array}{l}\text { Eszközök, } \\
\text { stratégiák }\end{array}$ & Eredmény/hatás \\
\hline Makro & Világbéke & Ösztöndíjak & $\begin{array}{l}\text { Társadalmi } \\
\text { integráció }\end{array}$ \\
\hline & Gazdasági növekedés & $\begin{array}{l}\text { Oktatási rendszerek } \\
\text { harmonizálása }\end{array}$ & $\begin{array}{l}\text { Versenyképes fel- } \\
\text { sőoktatási rendszer } \\
\text { a világpiacon }\end{array}$ \\
\hline Mikro & $\begin{array}{l}\text { Magas minőségü } \\
\text { munkaerő }\end{array}$ & $\begin{array}{l}\text { Nemzetközi } \\
\text { toborzás }\end{array}$ & $\begin{array}{l}\text { Képzett/vonzó } \\
\text { szakemberek }\end{array}$ \\
\hline & $\begin{array}{l}\text { Oktatási programok } \\
\text { minőségének növelése }\end{array}$ & $\begin{array}{l}\text { Nemzetközivé válás } \\
\text { otthon }\end{array}$ & $\begin{array}{l}\text { Hallgatói és munkál- } \\
\text { tatói elégedettség, } \\
\text { hírnév és hallgatói } \\
\text { létszám növelése }\end{array}$ \\
\hline & $\begin{array}{l}\text { Érdekes tanulási körül- } \\
\text { mények a hallgatóknak }\end{array}$ & $\begin{array}{l}\text { Külföldi tanulmá- } \\
\text { nyok és gyakorlatok }\end{array}$ & $\begin{array}{l}\text { Személyes gazdago- } \\
\text { dás és jobb elhelyez- } \\
\text { kedési lehetőség }\end{array}$ \\
\hline
\end{tabular}

Forrás: Van Gaalen (2010), 11.

A tanulmányi célú hallgatói migrációról nagyon alapos kutatást végzett Davis (2003) és L. Rédei (2009), míg a globális mobilitás koncepcionális megközelítéseit Mazzarol - Normann (2001) és Bhandari Laughlin (2009) könyvei tárgyalták részletesen. Az Európai Unió megbízásából Ulrich Teichler és munkatársai végeztek átfogó kutatást és trendelemzést az Európában megvalósuló mobilitás feltérképezésére (Teichler et al. 2011). Ebben a diplomaszerző diákmobilitás mellett a kreditszerző diákmobilitásra, illetve az oktatói mobilitásra helyezik a fő hangsúlyt. Az adatszolgáltatások megbízhatatlansága, illetve részlegessége miatt nem tárgyalják az egyes európai nemzetek külföldön, diplomaszerző programban tanuló hallgatóinak a létszámát, összetételét. ${ }^{1}$ Véleményünk szerint azonban szükség van a közgazdasági input-output elemzések logikája mentén is modellszerűen haladni, amelyhez adatok szerezhetők az OECD, illetve az UNESCO statisztikai kiadványaiból.

\footnotetext{
1A tanulmány részletesen foglalkozik azzal a migráció okozta problémával, hogy a külföldi státusú hallgatók (foreign students) nem azonosak a beérkező hallgatókkal (incoming mobile students), de a statisztika nem tesz közöttük különbséget. Németország esetében például a külföldi státusú hallgatók egynegyede nem „beérkező” diák, mert már a középiskoláit is Németországban végezte. Éppen ezért egyidejűleg tesznek javaslatot a mobilitási statisztikák jövőbeni fejlesztésére és a jelenlegi mobilitási szint emelésére. (A 32 országra kiterjedő vizsgálatban a 2006/07-es esztendőben a külföldi hallgatók beiskolázása 6,9\%-ot tett ki. A magyar adat a felsőoktatás egészére 3,9\%, de még a nappali képzésen is csak 5,0\%.)
} 
2. táblázat: A nemzetközi hallgatói mobilitás export-import alakulása és megoszlása, 2010

\begin{tabular}{|l|r|r|r|r|}
\hline Küldő / fogadó régiók & Bejövő, 2010 & Bejövő, \% & Kimenő, 2010 & Kimenő, \% \\
\hline Nyugat-Európa & 1259285 & $35,46 \%$ & 445999 & $14,36 \%$ \\
Észak-Amerika & 780304 & $21,97 \%$ & 96655 & $3,11 \%$ \\
Kelet-Ázsia és csendes-óceáni térség & 752253 & $21,18 \%$ & 1008732 & $32,48 \%$ \\
Közép- és Kelet-Európa & 321270 & $9,05 \%$ & 387245 & $12,47 \%$ \\
Arab államok & 219389 & $6,18 \%$ & 249277 & $8,03 \%$ \\
Fekete-Afrika & 89462 & $2,52 \%$ & 257099 & $8,28 \%$ \\
Latin-Amerika és Karib-térség & 68306 & $1,92 \%$ & 196888 & $6,34 \%$ \\
Közép-Ázsia & 43782 & $1,23 \%$ & 120795 & $3,89 \%$ \\
Dél- és Nyugat-Ázsia & 17629 & $0,50 \%$ & 343377 & $11,06 \%$ \\
\hline Összesen & 3551680 & $100 \%$ & 3106067 & $100 \%$ \\
\hline
\end{tabular}

Forrás: UNESCO (2012): 'Global Education Digest, 2012’

A nemzetközi hallgatói mobilitással kapcsolatos legfrissebb statisztikákat a 2.2. táblázat közli régiókra lebontva. A táblázatból jól látható, hogy a legtöbb bejövő nemzetközi hallgatót 2010-ben is Nyugat-Európa (1 259286 fö), Észak-Amerika (780 204 fö), illetve Kelet-Ázsia és a csendes óceáni térség (752 253 fö) fogadja. Ez a három régió együttesen a beérkező nemzetközi hallgatók közel $80 \%$-át felszívja, ami igen nagy koncentrációnak felel meg. A Magyarország szempontjából irányadó közép- és kelet-európai régió 9\%-kal (321 2\%0 fö) részesedik a nemzetközi hallgatók fogadásából, a feltörekvő piacok első helyét foglalva el.

Ami a küldő régiókat, azaz a kimenő hallgatókat illeti, Kelet-Ázsia és a csendes-óceáni térség (1 008 732) a meghatározó, melyet Nyugat-Európa valamint Közép- és Kelet-Európa követ (445 999 illetve 387245 fö). A dél- és nyugat-ázsiai régió a 11\%-os részesedésével a negyedik helyet foglalja el. A 2. táblázatból tehát egyértelműen kirajzolódik, hogy Nyugat-Európa és Észak-Amerika nettó tudás-exportőrként jelenik meg a nemzetközi felsőoktatási piacon, míg a többi régió a felsőfokú ismeretek és tudás importőreként van jelen a piacon. Az export és az import arányának különbsége a dél- és nyugat-ázsiai régiónál a legnagyobb. Az egyes régiók közötti különbségeket jól szemléleti a az 1. ábra. 
1. ábra: A nemzetközi hallgatói áramlás export-import alakulása (2010)

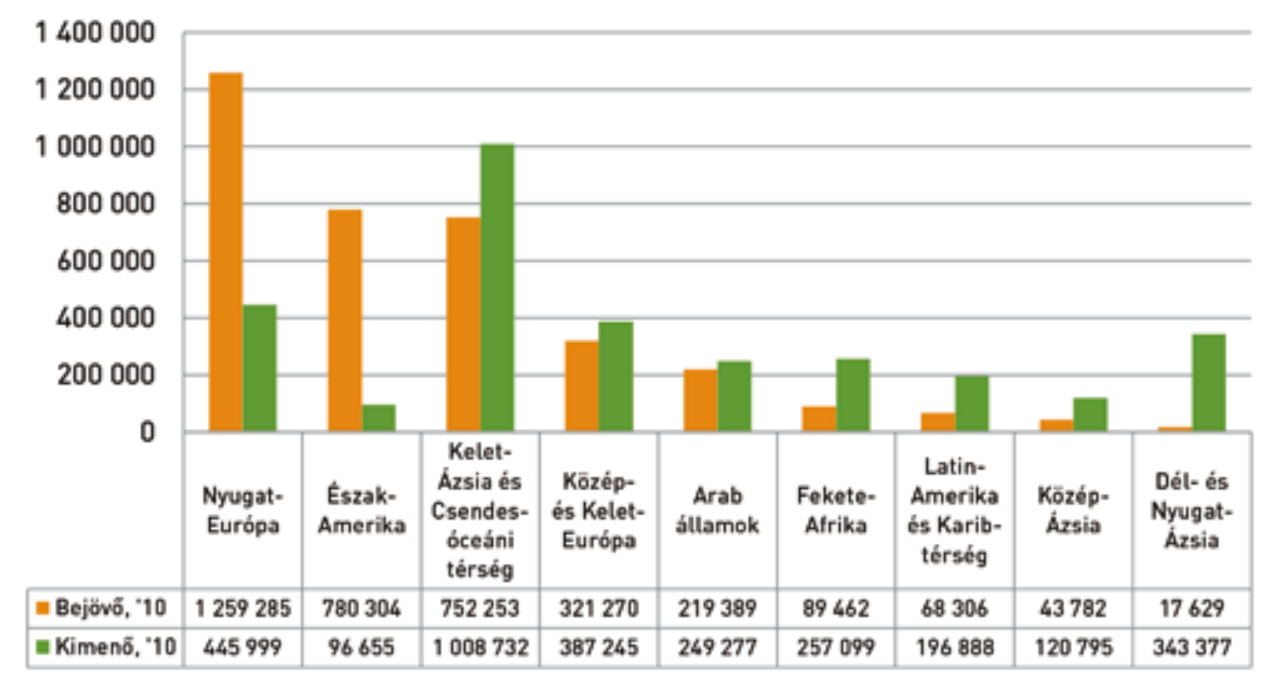

Forrás: UNESCO (2012): 'Global Education Digest, 2012'

Az egyes régiókban tapasztalható nemzetközi hallgatói áramlások átrendeződését két időszak összehasonlításával szemléltetjük. A 2., illetve 3. ábra az egyes régiókba beáramló hallgatók alapján kialakult piaci viszonyokat tükrözi a 2004-es és 2010-es években. Mindkét ábrán az $x$ tengelyre a bejövő hallgatók, míg az y tengelyre a kimenő hallgatók számát vittük fel. A buborékok mérete az egyes régiók beáramló hallgatókból való részesedését mutatja a globális piachoz viszonyítva (pl. a 2. ábra szerint Fekete-Afrikába 2004-ben a nemzetközi hallgatók 2,46\%-a érkezett). Az egyes régiók különböző stratégiai csoportokba sorolhatók attól függően, hogy - intézményi, földrajzi és kulturális adottságaiknak vagy jól felépített felsőoktatási ágazati stratégiájuknak köszönhetően - exportőrként vagy importőrként jelennek meg a nemzetközi felsőoktatási piacon. Az első stratégiai csoportba a piac meghatározó szereplői, NyugatEurópa és Észak-Amerika tartoznak. Ők ketten a bejövő hallgatók közel 70\%-át felszívják. Érdekes, hogy míg Észak-Amerikából relatíve kevés hallgató (42 241 fö) megy külföldre, addig Nyugat-Európában ez a szám is jelentős, 413352 fő 2004-ben. A második stratégiai csoport a 2. ábrán az origóhoz közel elhelyezkedő régiók csoportja (Dél- és Nyugat-Ázsia, Közép-Ázsia, Latin-Amerika és Karib-térség, FeketeAfrika, arab államok, valamint Közép- és Kelet-Európa). Az említett országcsoportok 2004-ben még inkább küldő országok voltak, mintsem olyan desztinációk, melyek kiemelkedő színvonalú egyetemekkel, jól kiépített kampuszokkal csábítanák a külföldön tanulni szándékozó hallgatókat. A harmadik stratégiai csoportot egy régió, a kelet-ázsiai és a csendes-óceáni térség országai adják. Ez a régió félúton halad a második csoportba sorolható (nettő importőr pozícióban levő országok) és a nettő exportőrök jelzővel illethető első csoport között. Ide számbelileg is több nemzetközi hallgató érkezik, és ez a szám nem marad el jelentősen a kimenő hallgatók számától. 


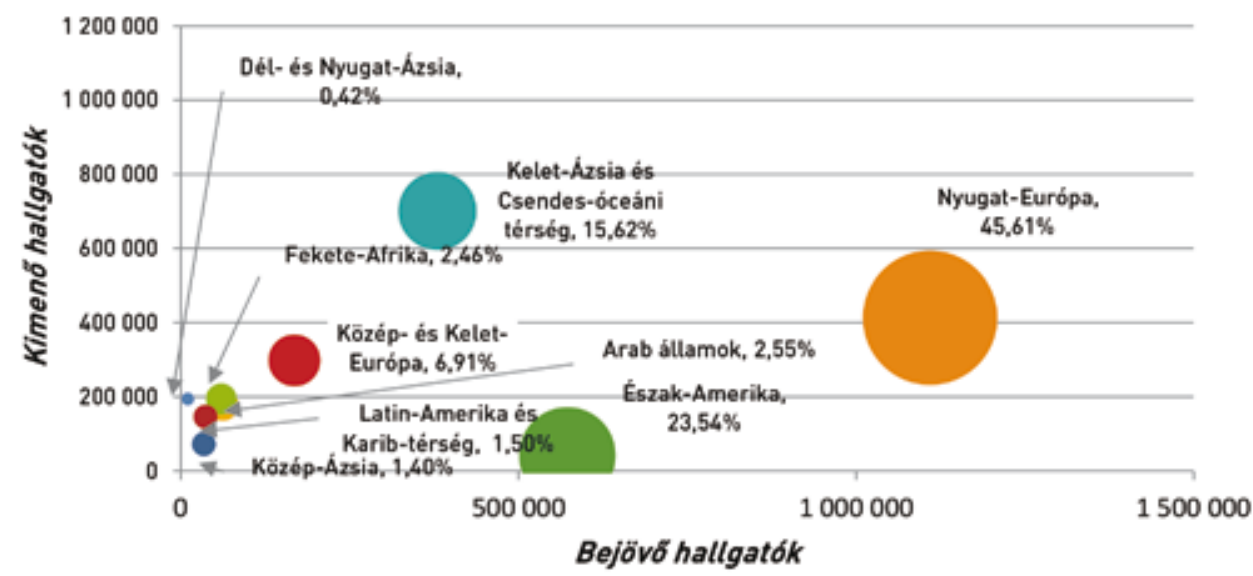

Forrás: UNESCO (2006): ‘Global Education Digest, 2006’

A 3. ábrán a vizsgált régiók viszonylatában a 2010-es állapotokat követhetjük nyomon. A buborékok mérete és elhelyezkedése alapján látható, hogy az első stratégiai csoportba sorolható régiók relatív piaci részesedése csökkent (5\%\%), és a piacvesztés a többi régió megerősödésének tudható be. A harmadik stratégiai csoportba sorolható kelet-ázsiai és csendes-óceáni térség például jelentősen növelte a bejövő hallgatók piacán tapasztalható relatív piacrészesedését, beérve Észak-Amerikát a beérkező hallgatók viszonylatában (22\% Észak-Amerika, 21\% Kelet-Ázsia és a csendes-óceáni térség), a kimenő hallgatók viszonylatában tovább növelve eddig is meglévő tetemes előnyét. A kisebb régiók (első stratégiai csoport) esetében is megfigyelhető némi elmozdulás. A korábban szorosan tömörülő régiók elválnak egymástól, követve saját logikájukat (stratégiai irányukat). Kiemelendő Közép- és Kelet-Európa (9\%-os), valamint az arab államok (6\%-os) piacrészesedésének növekedése, megteremtve az egyensúlyt a bejövő és kimenő hallgatók viszonylatában. A buborékok mérete és elmozdulása tükrözi, hogy a korábban meglévő stratégiai csoportok kezdenek felbomlani, és minden régió saját stratégiával jelenik meg a nemzetközi hallgatói piacon, hogy oktatási portfólióját és kínált szolgáltatásait az egyre nagyobb méreteket öltő globális fizetős felsőoktatási piacon értékesítse. 
3. ábra. A nemzetközi hallgatói áramlás mérlege, bejövő (2010)

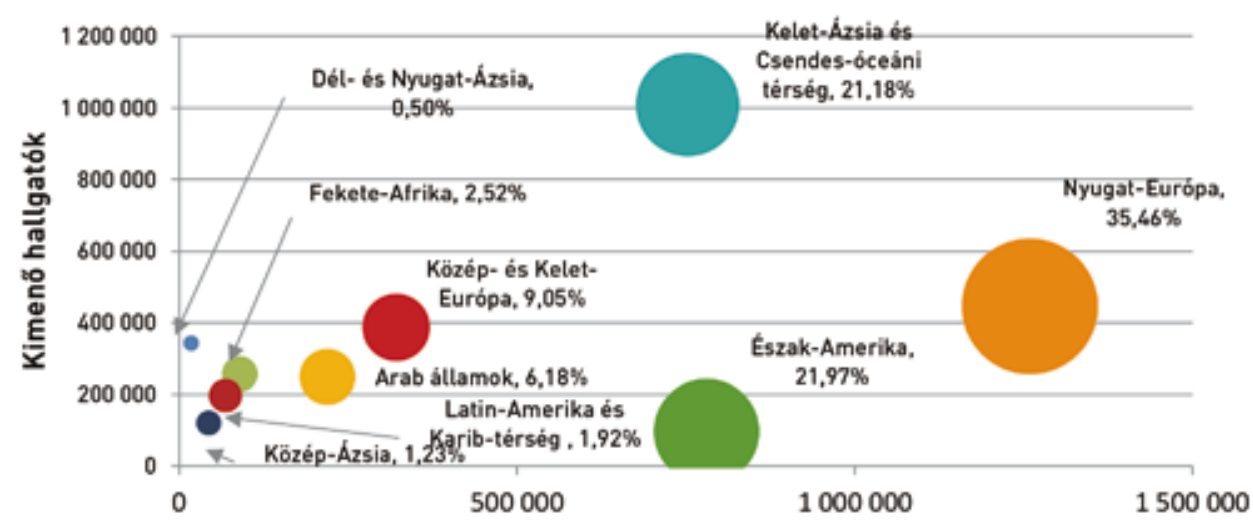

Forrás: UNESCO (2012): 'Global Education Digest, 2012'

A bejövő hallgatók regionális megoszlását 2010-ben a 4. ábra illusztrálja, ezzel egy másik oldalát érzékeltetve ugyanazon adatoknak.

4. ábra. Bejövő hallgatók globális megoszlása (2010): 3572840 fö

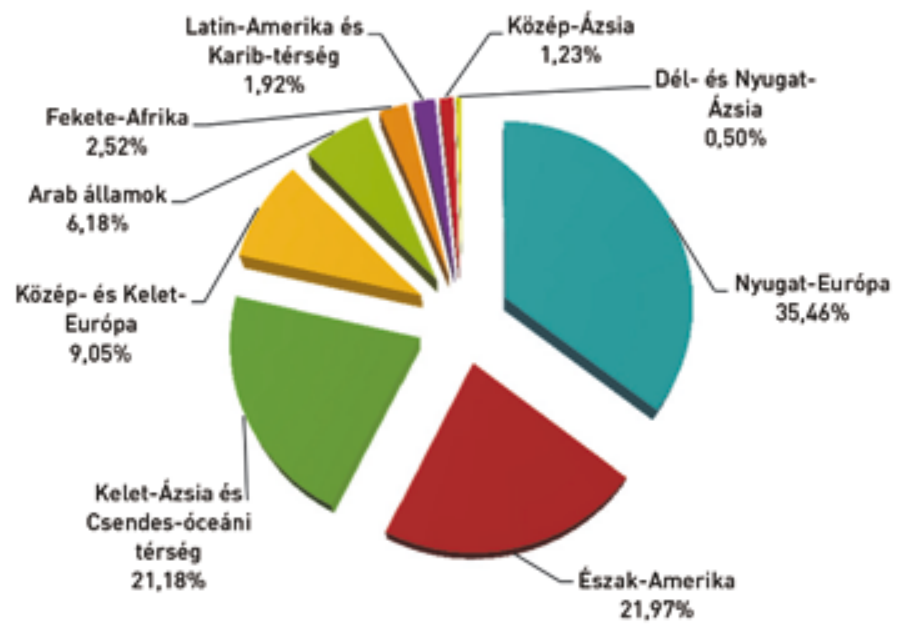

Forrás: UNESCO (2012): 'Global Education Digest, 2012’ 
A nemzetközi hallgatói áramlásokban megfigyelhető változásokat egy harmadik oldalról szemléleti az 5. ábrán felrajzolt görbe, amely a beérkező hallgatók régiók közötti megoszlását mutatja két időszak összehasonlításával.

5. ábra. A nemzetközi hallgatói áramlás mérlege, bejövö (2004/2010)

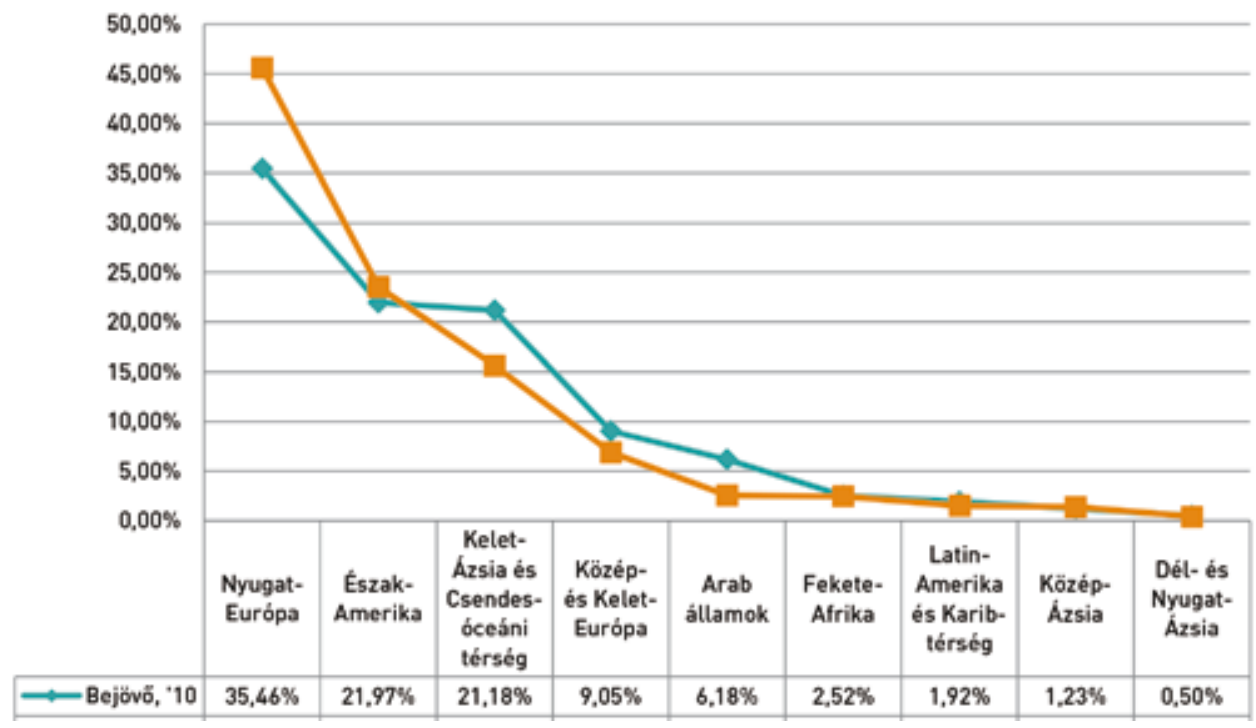

Forrás: UNESCO (2006): ‘Global Education Digest, 2006’; UNESCO (2012): 'Global Education Digest, 2012'

A beérkező hallgatók kapcsán megfigyelhető tendenciaváltozások mellett fontos követni a kimenő oldalon megfigyelhető eltolódásokat is. Ehhez nyújt segítséget a 6 . ábra. A görbék alakulásából jól látható, hogy a 2004-es kiinduló időszakhoz képest több diákot küldő régiók 2010-ben rendre a következők: Dél- és Nyugat-Ázsia (2,38 százalékpontos növekedés), Észak-Amerika (1,22 százalékpontos növekedés), Kelet-Ázsia és csendes-óceáni térség (1,16 százalékpontos növekedés), Közép-Ázsia (0,65 százalékpontos növekedés), valamint az arab államok (0,10 százalékpontos növekedés). A kimenő hallgatók tekintetében csökkenést regisztráló régiók a következők: Nyugat-Európa (4,11 százalékpontos csökkenés), Közép- és Kelet-Európa (0,85 százalékpontos csökkenés), Fekete-Afrika (0,38 százalékpontos csökkenés), valamint Latin-Amerika és Karib-térség ( 0,17 százalékpontos csökkenés). Az 5. és 6 . ábrán feltüntetett trendek alapján jól látható, hogy egyes régiók veszítenek népszerűségükből, míg más régiók egyre keresettebbé válnak a felsőfokú tanulmányaikat külföldön folytatni szándékozó hallgatók körében. Nyugat-Európa például, mind küldő, mind fogadó oldalon, arányaiban kevesebb hallgatót mozgat meg, míg Kelet-Ázsiát és a csendes-óceáni térséget, Dél- és Nyugat-Ázsiát, valamint az arab államokat a korábbinál több hallgató választja desztinációként, ugyanakkor e régiók egyre több hallgatót küldenek külföldre is. 
6. ábra: A nemzetközi hallgatói áramlás mérlege, kimenö (2004/2010)

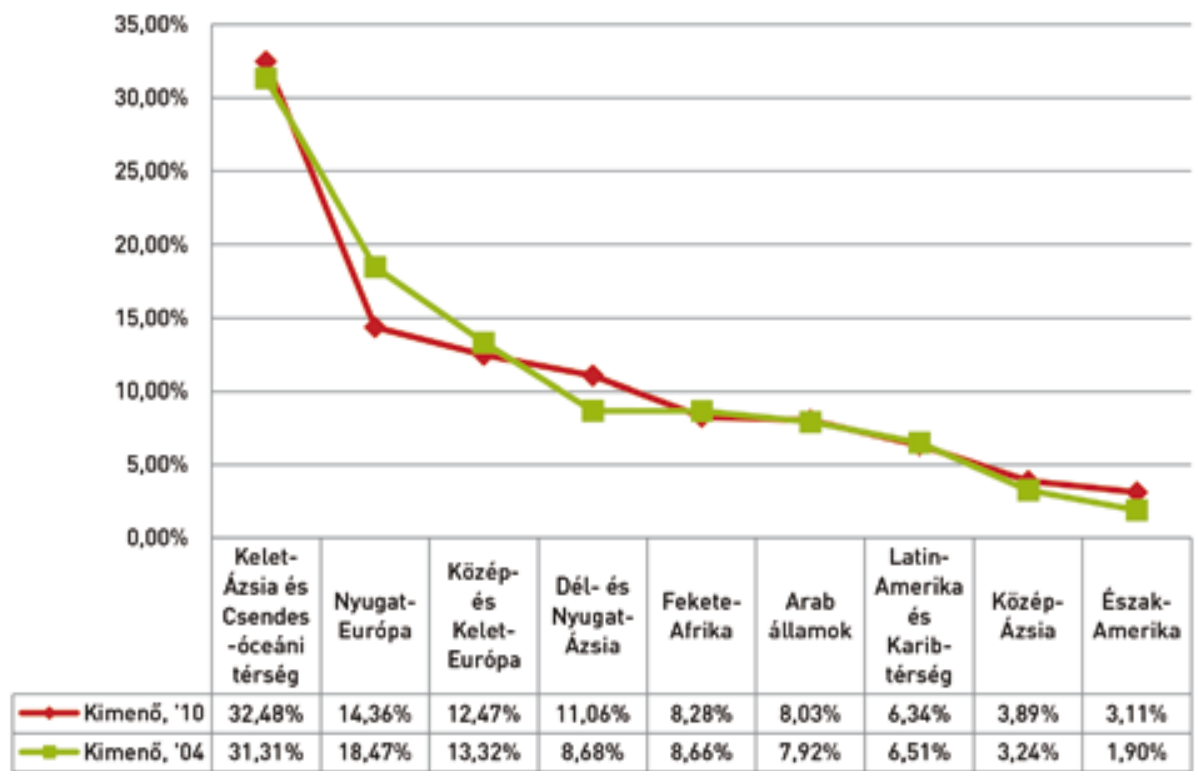

Forrás: UNESCO (2006): 'Global Education Digest, 2006'; UNESCO (2012): 'Global Education Digest, 2012'

Fontos megállapítani, hogy a különböző országcsoportok, régiók nagyobb kiegyensúlyozottságot mutatnak a kimenő hallgatók vizsgálatakor, mint amit a beérkező hallgatók fogadásában jeleskedő régiók megoszlásánál tapasztalhattunk. Ebből arra is lehet következtetni, hogy a különböző régiókban - a népességbeli számokban tapasztalható különbségek ellenére - hasonló mértékű igény mutatkozik más nemzetek kultúrájának megismerése, nemzetközi tapasztalatok gyüjtése és más országok állampolgáraival való kapcsolatok kiépítése iránt. Ez megfelelő táptalajt biztosít a globális felsőoktatási piac korábbinál nagyobb mértékű kiterjedéséhez.

\subsection{A nemzetközi diákmobilitás országok szerinti megoszlása és változása}

Az országok szerinti megoszlás vizsgálatánál alapvetően kétféle statisztikát érdemes elemezni. Egyrészt érdemes megnézni azt, hogy a felsőoktatásba bekerülő új hallgatók honnan érkeznek és hová mennek, másrészt, hogy milyen a teljes hallgatói állomány országok szerinti megoszlása.

Az újonnan belépő hallgatók származási helyek (küldő országok) szerinti megoszlását a 7. ábra adja meg a TOP 10 ország viszonylatában. A Project Atlas adatai alapján 2012-ben 764 495 új belépő hallgató került a globális felsőoktatási szektorba. A legnagyobb küldő ország továbbra is Kína, ám jelentősen növelte piaci részesedését (25\%) a 2001-es évhez képest. A második helyet India őrzi 13\%-os piaci részesedéssel, amit a harmadik helyre feljött Koreai Köztársaság követ 9,5\%-os piaci részesedéssel. Őket az újonnan bekerülő Szaúd-Arábia (4,5\%) követi, aki Thaiföldet szorította ki a TOP 10-ből. Érdekes, hogy 2012-ben a TOP 10 küldő ország már a piac 67\%-át lefedi, ami jelentős növekedés 2001-hez képest, ahol a koncentrációs mutató még csak $56 \%$ volt. 
7. ábra: Top 10 küldő ország, új belépő hallgatók (2012): 764495

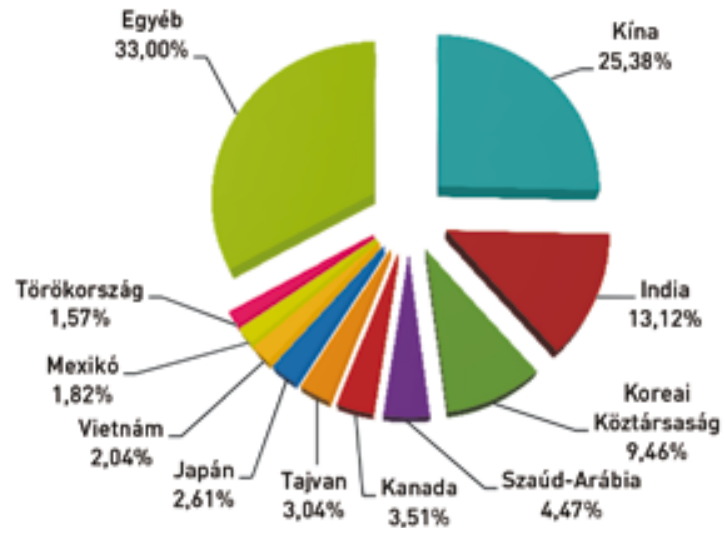

Forrás: Open Doors 2012 Data

Az UNESCO adatai alapján 2010-ben 3572840 diák folytatja felsőfokú tanulmányait külföldön, ami 2004hez képest 45,5\%-os piacbővülésnek felel meg (8. ábra). A TOP 10 országok rangsorát továbbra is Kína vezeti (16\%), amit India és a Koreai Köztársaság követ. Említésre méltó még Németország negyedik helyre lépése, ami jól tükrözi a német felsőoktatás nemzetköziesedésének előmozdítása érdekében tett kormányzati lépéseket. A nemzetközi tudományos konferenciákon egyre több német doktorandusszal, kutatóval találkozhatunk, akik a nemzetközi sztenderdeknek megfelelően magas színvonalú előadásokat tartanak. Fontos továbbá megemlíteni Görögországot, mely 2004-ben még a kilencedik helyen állt a TOP 10 küldő országok rangsorában, 2010-re azonban már kikerült onnan. Az elhúzódó gazdasági válság és az országot érintő strukturális reformok végrehajtása szembetűnő módon kihat az egész felsőoktatási ágazat működösére, és megnehezíti a kiutazáshoz szükséges pénzügyi források előteremtését.

8. ábra: Top 10 küldő ország (2010): 3572840

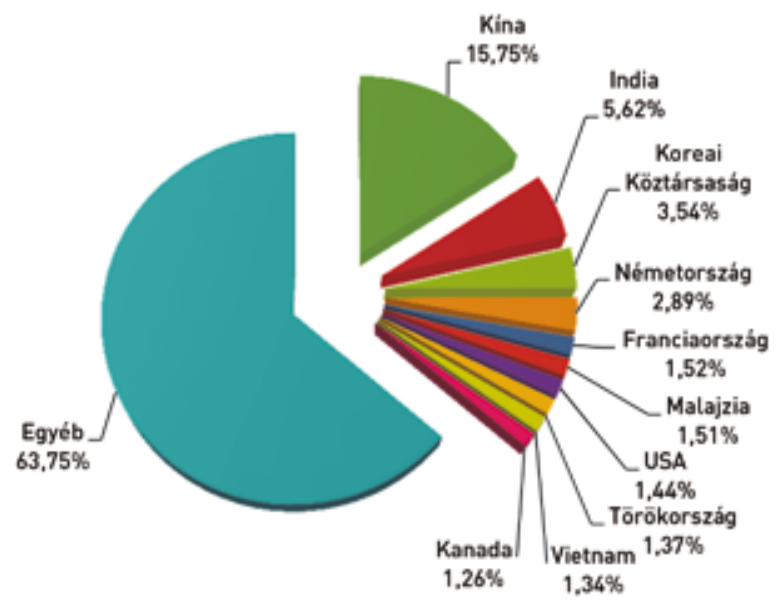

Forrás: UNESCO (2012): 'Global Education Digest, 2012 
Az UNESCO statisztikái alapján 2010-ben 3572841 diák folytatja felsőfokú tanulmányait külföldön (9. ábra). A legkedveltebb célország az USA 19\%-os piacrészesedéssel, a második helyen az Egyesült Királyság áll 11\%-kal, míg a harmadik helyet Ausztrália foglalja el. Az egyéb országok 35\%-ot tesznek ki. Összevetve a 2004-es adatokkal megállapítható, hogy a legtöbb vezető ország veszített piaci részesedéséből 2010-re (pl. USA 4,15; Egyesült Királyság 1,31; Németország 4,98; Franciaország részesedése 2,40 százalékponttal csökkent). Franciaország a százalékos csökkenés ellenére abszolút számokban növekedést regisztrált és megelőzte Németországot. Vannak azonban növekedést felmutatni képes országok is, mint pl. Ausztrália, Oroszország, Olaszország, és a 2010-ben új szereplőként is megjelenő Kína, 2,01\%os piacrészesedéssel. A kisebb országok számára pozitív jel, hogy az egyéb országok piaci részesedése 11,56\%-kal emelkedett, ami jelentős preferenciabeli eltolódást jelez. Itt jegyezzük meg, hogy ezzel ellentétes trendet jelez az IIE Atlas of Student Mobility jelentése, amelyben 2011-ben a 4,1 millió külföldi hallgató 7\%-a már Kínában tanult, amely ezzel a nagyságrenddel feljött a negyedik helyre.

9. ábra: Top 10 fogadó ország (2010): 3572840

Forrás: UNESCO (2012): 'Global Education Digest, 2012'

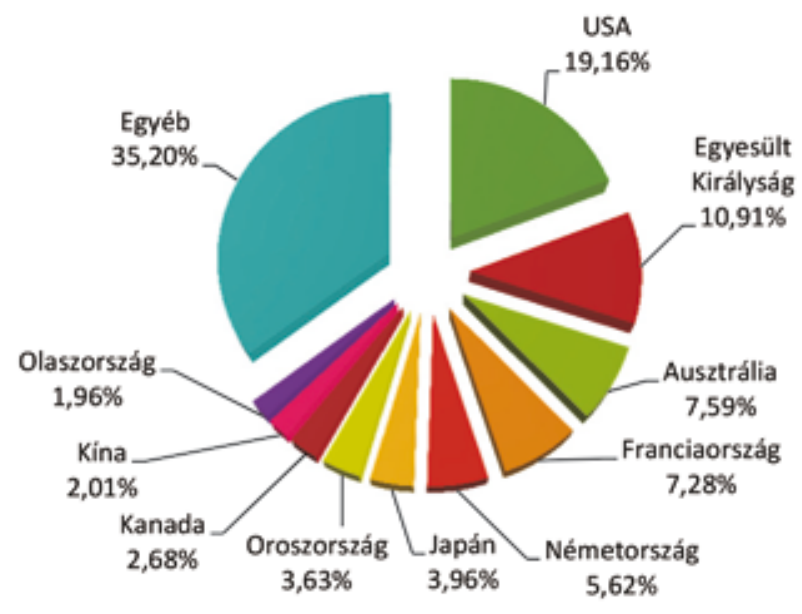

Az OECD legfrissebb elérhető statisztikája alapján (OECD, 2012) jelentős átrendeződés figyelhető meg a közép-európai felsőoktatási piacon az elmúlt 10 esztendőben a hallgatók fogadása és küldése viszonylatában. Ausztria 2010-ben 68619 nemzetközi hallgatót fogadott (117\%-os növekedés 2001-hez képest) Csehország 34992 hallgatóval feljött a második helyre (352\%-os növekedés), míg Magyarország elveszítve korábban őrzött regionális második helyét a negyedik helyre esett vissza (14 518 beérkező hallgató, 29\%-os növekedés). Lengyelország szintén növelte beérkező hallgatói számát 2001-hez képest (16 976 beérkező hallgató, 155\%-os növekedés). Szlovákiába is több külföldi hallgató érkezik (7 946 beérkező hallgató, 370\%-os növekedés), ám fontosabb a korábban látott nettó importőr pozíciójának jelentős erősödése (30 835 kimenő hallgató). Csehország nettő exportőr pozíciójának és Szlovákia nettó importőr pozíciónak megerősödése vélhetően összefügg, hiszen jelentős számú szlovák állampolgár tanul neves cseh felsőoktatási intézményekben (10. ábra). Ezt a tendenciát a nyelvi és kulturális hasonlóságok, valamint a két ország korábbi történelmi összefonódása is erősíti. Magyarország, 
mint fogadó ország regionális viszonylatban tapasztalható visszaesése vélhetően annak is köszönhető, hogy a 2000-es évek kezdetével fokozatosan beindultak a határon túli magyar képzést nyújtó felsőoktatási programok, autonóm oktatási intézmények jöttek létre, ahol a magyar ajkú kisebbség anyanyelvén folytathatja felsőfokú tanulmányait.

10. ábra: Bejövő hallgatók száma a bejövö és kimenö hallgatók arányában, 2010 Forrás: OECD (2012): 'Education at a Glance', 2012

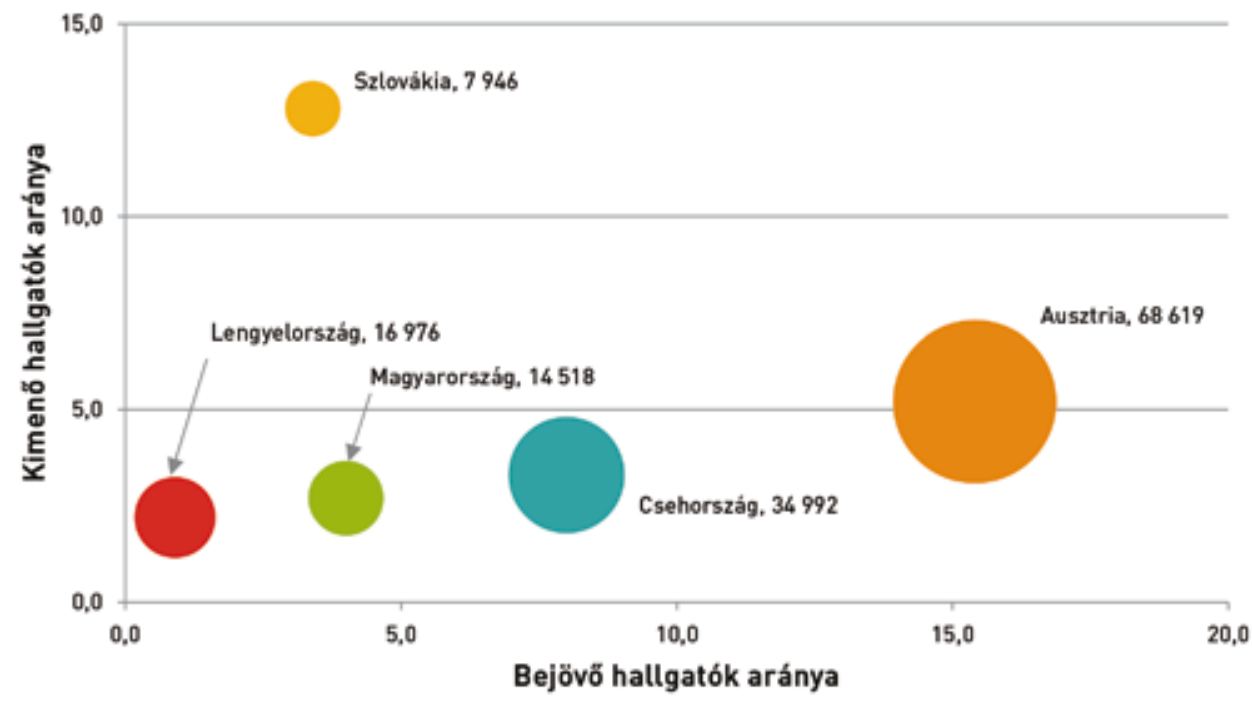

\section{Hazai helyzetkép a külföldi hallgatók fogadásában}

A magyar felsőoktatásban tanulók számának 15 éven át tapasztalt dinamikus növekedése, a felsőoktatás tömegessé válása, majd az elmúlt 7 évben tapasztalt (részben demográfiai okokra visszavezethető) csökkenése, viszonylagosan is megnöveli a külföldi hallgatók jelentőségét. Miként a 11. ábrából kiderül, a külföldi hallgatók aránya viszonylag keskeny, de növekvő csíkot jelöl (ez különösen igaz a nappali munkarendben tanuló hallgatókra). 
11. ábra: Külföldi hallgatók a magyar felsőoktatásban, összes munkarend (2001-2011)

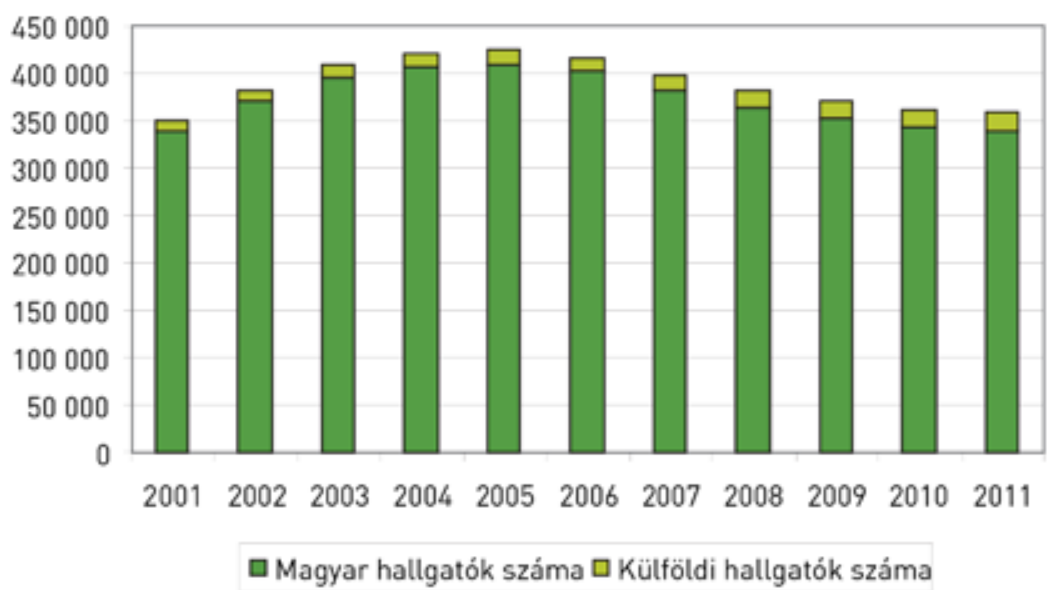

Forrás: Emberi Erőforrások Minisztériuma, felsőoktatási statisztikai adatok alapján saját szerkesztés

A külföldi hallgatók regionális megoszlása (3. táblázat) sok tartalékot rejt magában, ha figyelembe veszszük a korábban tárgyalt nemzetközi trendeket. Így például az USA-ban és a többi angolszász országban a külföldi hallgatók többsége Ázsiából származik, és ez az arány várhatóan nem változik. Tudatos stratégiával lényegesen növelni lehetne hazánkban is az ázsiai és afrikai diákok számát (Bhandari - Laughlin 2009).

3. táblázat: A magyar felsőoktatásban tanuló külföldi hallgatók száma és megoszlása régiónként (2009/2010, 2011/2012)

\begin{tabular}{|l|l|l|l|l|}
\hline \multirow{2}{*}{ Régió } & \multicolumn{2}{l}{$2009 / 2010$} & \multicolumn{2}{l|}{$2011 / 2012$} \\
\cline { 2 - 6 } & Létszám & Arány & Létszám & Arány \\
\hline \multirow{2}{*}{ Afrika } & 524 & $2,89 \%$ & 721 & $3,57 \%$ \\
\hline Ázsia & 3548 & $19,54 \%$ & 4200 & $20,82 \%$ \\
\hline Észak- és Dél-Amerika & 530 & $2,92 \%$ & 690 & $3,42 \%$ \\
\hline Európa & 13536 & $74,56 \%$ & 14547 & $72,10 \%$ \\
\hline Óceánia & 16 & $0,09 \%$ & 18 & $0,09 \%$ \\
\hline Összesen & 18154 & $100,00 \%$ & 20176 & $100,00 \%$ \\
\hline
\end{tabular}

Forrás: Emberi Erőforrások Minisztériuma, felsőoktatási statisztikai adatok alapján saját szerkesztés 


\subsection{Külföldi hallgatók a diplomaszerző képzésben Magyarországon}

Az elmúlt évtizedben töretlenül nött a magyar felsőoktatásban tanuló külföldi hallgatók száma. 2001 őszén még 11783 külföldi hallgató folytatott tanulmányokat hazánkban diplomaszerzés céljából, a 2011/12-es tanévben pedig már 71\%-kal több, azaz 20176 fö. Mindez azt eredményezte, hogy megnőtt az összes hallgató között a külföldiek aránya, a 2001 és 2005 közötti időszakban stabil 3,4\%-ról 5,6 \%-ra (4. táblázat). Az abszolút növekedés lényegesen alatta marad a globálisan mért 90\%-os növekedésnek, ami azt is jelzi, hogy az aránynövekedés ellenére a világban betöltött szerepünk csökkent.

4. táblázat: Magyar és külföldi hallgatók a magyar felsőoktatásban

\begin{tabular}{|l|r|r|r|r|r|r|}
\hline & $\mathbf{2 0 0 5 / 2 0 0 6}$ & $\mathbf{2 0 0 6 / 2 0 0 \%}$ & $\mathbf{2 0 0 8 / 2 0 0 9}$ & $\mathbf{2 0 0 9 / 2 0 1 0}$ & $\mathbf{2 0 1 0 / 2 0 1 1}$ & $\mathbf{2 0 1 1 / 2 0 1 2}$ \\
\hline Összes hallgató & 424161 & 397704 & 381033 & 370331 & 361347 & 359824 \\
\hline $\begin{array}{l}\text { Ebből külföldi } \\
\text { hallgató }\end{array}$ & 14491 & 15459 & 16916 & 18154 & 18850 & 20176 \\
\hline $\begin{array}{l}\text { Külföldi hall- } \\
\text { gató \% }\end{array}$ & $\mathbf{3 , 4 0 \%}$ & $\mathbf{3 , 9 0 \%}$ & $\mathbf{4 , 4 0 \%}$ & $\mathbf{4 , 9 0 \%}$ & $\mathbf{5 , 2 0 \%}$ & $\mathbf{5 , 6 0 \%}$ \\
\hline $\begin{array}{l}\text { Nappali hall- } \\
\text { gató }\end{array}$ & 231482 & 242893 & 242928 & 242701 & 240727 & 241614 \\
\hline $\begin{array}{l}\text { Ebből külföldi } \\
\text { hallgató }\end{array}$ & 10974 & 12212 & 13681 & 15035 & 15889 & 17112 \\
\hline $\begin{array}{l}\text { Külföldi hall- } \\
\text { gató \% }\end{array}$ & $\mathbf{4 , 7 0 \%}$ & $\mathbf{5 , 0 0 \%}$ & $\mathbf{5 , 6 0 \%}$ & $\mathbf{6 , 2 0 \%}$ & $\mathbf{6 , 6 0 \%}$ & $\mathbf{7 , 1 0 \%}$ \\
\hline
\end{tabular}

Forrás: Emberi Erőforrások Minisztériuma, felsőoktatási statisztikai adatok alapján saját szerkesztés

A külföldi hallgatók többsége $(84,8 \%)$ a nappali munkarendben tanul, ahol az átlagnál magasabb és szintén emelkedő arányban vannak jelen. Arányuk hat év alatt 4,7\%-ról 7,1\%-ra nőtt, ami azért is örvendetes, mert a nappali hallgatók abszolút száma sem csökkent ebben az időszakban. A képzési tagozatok szerinti megoszlást (5. táblázat) vizsgálva megállapítható, hogy a magyar hallgatók esetében tapasztalt trend jelent meg a külföldi hallgatóknál is. Az esti képzés és a távoktatás aránya jelentősen visszaesett, ahol az utóbbi azért is meglepő, mert az internetes, online technológia megjelenése a felsőoktatásban azt az ígéretet hordozta, hogy egyetemeink ezen az értékesítési úton hozzáférhetőbbé válnak a külföldi hallgatók számára. De nem ez történt. A levelező képzésben részt vevő külföldi hallgatók száma a korábbi stagnálás után abszolút értékben nőtt ugyan a legutóbbi vizsgált tanévben, de a képzési forma jelentősége relatíve még így is csökkent.

5. táblázat: Külföldi hallgatók száma a magyar felsőoktatásban képzési tagozatonként

\begin{tabular}{|l|r|r|r|r|r|r|}
\hline $\begin{array}{l}\text { Képzési } \\
\text { tagozat }\end{array}$ & $\mathbf{2 0 0 5 / 2 0 0 6}$ & $\mathbf{2 0 0 6 / 2 0 0 7}$ & $\mathbf{2 0 0 8 / 2 0 0 9}$ & $\mathbf{2 0 0 9 / 2 0 1 0}$ & $\mathbf{2 0 1 0 / 2 0 1 1}$ & 2011/2012 \\
\hline Nappali & 10974 & 12212 & 13681 & 15035 & 15889 & 17112 \\
\hline Esti & 231 & 166 & 134 & 136 & 98 & 87 \\
\hline Levelező & 2654 & 2602 & 2706 & 2745 & 2692 & 2857 \\
\hline
\end{tabular}




\begin{tabular}{|l|r|r|r|r|r|r|}
\hline Távoktatás & 632 & 479 & 395 & 238 & 171 & 120 \\
\hline Összesen & 14491 & 15459 & 16916 & 18154 & 18850 & 20176 \\
\hline
\end{tabular}

Forrás: Emberi Erőforrások Minisztériuma, felsőoktatási statisztikai adatok alapján saját szerkesztés

Földrajzi és tartalmi szempontból is nagy jelentősége van annak, hogy milyen stratégiai országcsoportokat hozunk létre a külföldi hallgatókból. Célunknak leginkább egy hármas csoportosítás felel meg: szomszédos országok - egyéb európai országok - más földrészek. A 2011/2012-es tanévben a világ 127 országából érkeztek Magyarországra külföldi hallgatók, de ezek közül csak 30 ország volt, ahonnan 100-nál több főt fogadtunk, ezeknek az adatait tartalmazza a 6. táblázat. A C30 koncentrációs mutató - amely a legnagyobb küldő országok összes küldőn belüli súlyát mutatja - értéke 93,1\%, a korábbi évekhez képest nem változott jelentősen.

6. táblázat: A 100 fönél több hallgatót küldő 30 ország hallgatói a 2011/2012-es tanévben, fö stratégiai csoportonként

\begin{tabular}{|c|c|c|c|c|c|}
\hline $\begin{array}{l}\text { Szomszédos } \\
\text { ország }\end{array}$ & Fő & Európa & Fö & Más földrész & Fö \\
\hline 1. Románia & 2736 & 1. Németország & 2342 & 1. Irán & 979 \\
\hline 2. Szlovákia & 2533 & 2. Norvégia & 812 & 2. Izrael & 743 \\
\hline 3. Szerbia & 1646 & 3. Svédország & 440 & 3. Törökország & 520 \\
\hline 4. Ukrajna & 1328 & 4. Spanyolország & 328 & 4. Nigéria & 483 \\
\hline 5. Ausztria & 140 & 5. Franciaország & 302 & 5. USA & 426 \\
\hline \multirow[t]{8}{*}{ 6. Horvátország } & 135 & 6. Nagy-Britannia & 261 & 6. Kína & 290 \\
\hline & & 7. Ciprus & 232 & 7. Koreai Köztársaság & 259 \\
\hline & & 8. Olaszország & 232 & 8. Vietnám & 227 \\
\hline & & 9. Írország & 194 & 9. Szaúd-Arábia & 223 \\
\hline & & 10. Görögország & 185 & 10. Japán & 215 \\
\hline & & 11. Oroszország & 147 & 11. Kanada & 186 \\
\hline & & 12. Lengyelország & 131 & & \\
\hline & & 13. Portugália & 103 & & \\
\hline Összesen & 8518 & Összesen & 5709 & Összesen & 4551 \\
\hline Ország csoport \% & $42,2 \%$ & Ország csoport \% & $28,3 \%$ & Ország csoport \% & $22,6 \%$ \\
\hline
\end{tabular}

Forrás: Emberi Erőforrások Minisztériuma, felsőoktatási statisztikai adatok alapján saját szerkesztés Megjegyzés: Az előző évhez képest csökkenést regisztráló országokat dőlt betűvel szedtük

Az első csoportba azokat soroljuk, akik a szomszédos országokból jöttek és döntően magyar nyelven tanulnak. Róluk gyakran még az egyetemi vezetők, dékánok sem tudják, hogy külföldiek, nem jelennek meg külön entitásként, elkeverednek a magyar állampolgárságú hallgatók között. A kettős állampolgárság még inkább felerősítheti ezt a helyzetet. Számuk lassan, de még mindig növekszik, 
annak ellenére, hogy számarányuk csökken az összes külföldi hallgatón belül. 2007-ben 54\%-ot tett ki az arányuk, 2011-ben pedig még mindig magas, de már csak 42,2\% volt. Ez 11,8 százalékpontos részesedés-csökkenést jelent négy év alatt.

A szomszédos országok között Románia vezeti a rangsort, abszolút értelemben véve a korábbi években csökkenő, de 2011-ben enyhe növekedést mutató 2736 fős hallgatói létszámmal. A csökkenés valószínűleg két okra vezethető vissza. Egyrészt az uniós tagság miatt a romániai magyar fiatalok számára is megnyílt az út Nyugat-Európa egyetemei felé, és többen választják ezt az irányt. (Németországban és Franciaországban például határozottan megnőtt a romániai diákok száma, miként az USA-ban is.) Másrészt az elmúlt években emelkedett az erdélyi egyetemek magyar nyelvü programjain tanuló hallgatók száma. A Babes-Bolyai Egyetemen a 37000 román hallgató mellett 10600 magyar nemzetiségü hallgató is tanul, közülük 7336 fö a magyar nyelvü tagozaton (Marga 2010)². A másfél milliós erdélyi magyar lakosságot tekintve a Babes-Bolyai Egyetem 7,1 magyar hallgatót produkált 1000 magyar lakosra vetítve.

A Magyarországon tanuló 2736 romániai hallgató nagy része magyar anyanyelvü, azaz megközelítőleg 2 Magyarországon tanuló hallgató jut 1000 magyar nemzetiségű román lakosra. Sok ez vagy kevés? Mekkora lehetőséget rejt a magyar felsőoktatás számára ez a terület? Magyarországon 2011-ben a felsőoktatási intézményekben tanuló hallgatók 1000 lakosra jutó száma 36 fő volt. Ennek megfelelő aránnyal számolva Romániában 52000 magyar anyanyelvü hallgatót kellene regisztrálni, ha nem lenne mobilitás és a magyar arányok lennének érvényesek az erdélyi magyarokra is (1500x36=52 500). Pontos számmal azonban nem rendelkezünk a romániai felsőoktatásban tanuló magyar nemzetiségü hallgatók létszámát illetően. A kisebbségi lét hátrányos helyzete mindaddig fennáll, amíg nem tudunk elszámolni azzal, hogy miért nem kerül be ennyi romániai magyar hallgató a felsőoktatásba. Ha így nézzük, akkor a 2730 Magyarországon tanuló romániai magyar diák csak 5,25\%-át adja a potenciális piacnak (2736:52 000=0,0525). Ez egyáltalán nem nagy szám és senkinek sem lehet érdeke, hogy csökkenjen. Inkább az, hogy növekedjen, különösen akkor, ha növekedne a Magyarországról Romániába utazó magyar hallgatók száma is.

A szomszédos országok közül Szlovákiából enyhén csökkenő, míg Szerbiából enyhén növekvő számú hallgató érkezett továbbra is. Ha az 1000 magyar nemzetiségű lakosra vetítjük az itt tanulók számát, akkor rendre 5,1 főt és 4,9 főt kapunk a korábbi módszertan alapján. Ukrajnából kevesebb, míg Horvátországból több hallgató érkezett, mint a megelőző évben, és 6 főre tehető az 1000 lakosra jutó hallgatók száma. A számok egyértelműen tükrözik, hogy minél kisebb a magyar lakosság száma, annál inkább szükség van az anyaország támogatására. Másrészt, ha ezeket a számokat is a 36 fős magyar értékhez viszonyítjuk, akkor nem látunk okot a csökkenésre, különösen, ha megfontoljuk, hogy a magyar nyelvű képzés lehetőségei ezekben az országokban korlátozottabbak, mint Romániában.

Stratégiai szempontból viszont fel kell vetni két aszimmetriát a szomszédos országok viszonylatában. Egyrészt nagyon kevés magyarországi diák tanul a szomszédos országokban, másrészt nagyon kevés román, szlovák, szerb, ukrán anyanyelvü tanul nálunk. Célként merülhet fel a magyar hallgatók ösztönzése arra, hogy Kolozsváron, Nagyváradon, Csíkszeredán, Temesváron, Pozsonyban, Kassán, Révkomáromban, Szabadkán, Újvidéken, Ungváron, stb. a magyar nyelvü képzésen tanuljanak. ${ }^{3}$ Másrészt a határon túl lévő magyar nyelven is tanító egyetemeknek, főiskoláknak Magyarországra is ki lehetne terjeszteni a marketing, hallgató toborzási tevékenységüket. Ebből a szempontból 2013 janu-

2 Ezt a pozitív változást az erdélyi magyar felsőoktatás kálváriájáról írott könyvükben a Balázs S. - Bodó B. - Csetri E. - Gaál Gy. - Kónya-Hamar S. -Somai J. (2009) szerzőcsapat is elismeri és számokkal igazolja. Ez persze nem homályosíthatja el azok véleményét, akik továbbra is a független magyar Bolyai Egyetem létrehozásán fáradoznak.

3 Ebből a szempontból példa értékű lehet a Babes-Bolyai Egyetem, ahol 1093 külföldi hallgató tanult 2009-ben. Ebből 421 fő román etnikai származású (pl. Moldovai Köztársaságból). Növekvő, de még mindig csak 83 fő jött Magyarországról (pl. pszichológiai diplomát szerezni). Miért csak ennyi, kérdezhetnénk? Hiszen Moldova sokkal távolabb van Kolozsvártól, mint a Nagy Alföld. Valószínűleg a „fejekben” kell rendet teremteni és komolyan venni, hogy a határok légiesülnek (Marga 2010). 
árjában úttörő szerepre vállalkozott a Babes-Bolyai Egyetem Gazdálkodástudományi Karának Magyar Intézete, amikor kiállítóként jelent meg az Educatio diákvásáron.

Ami a román, szlovák, szerb és ukrán hallgatók magyarországi tanulmányait illeti, itt a nyelvi korlátok dominálnak. Ennek leküzdésére szolgál, hogy a magyar egyetemek több nyelven (angol, német, francia) kínáljanak vonzó programot számukra, és hogy a nemzetköziség érezhető legyen a magyar egyetemeken, ne érezze magát senki elszigetelve. Ehhez persze szükség van arra, hogy a külföldi hallgatók száma országos szinten is megtöbbszöröződjön.

A második csoportba a többi európai országot soroljuk. Ezt a kategóriát Németország vezeti egyre növekvő hallgatói létszámmal (2011/2012-ben 2342 német hallgató tanult nálunk). Ezt követi Norvégia és Svédország évek óta stabil második és harmadik helyezéssel. A korábban előkelő helyen szereplő Ciprus, Oroszország és Görögország hátrébb sorolódott a spanyol, francia és az angol diákok nagyobb száma miatt. A táblázatban csak a 100 főnél nagyobb hallgatói létszámot tüntettük fel. Nagy kérdés, hogy miben tudunk versenyképesek lenni a fejlett országok felsőoktatásához képest? Az alacsony ár (tandíj) fontos tényező, de nem meghatározó, hiszen sok helyen ingyenes az oktatás. Elsősorban az akadémiai tartalom határozza meg a vonzerőt. Az orvosi képzés rendelkezik ezzel, valamint azzal a stratégiai előnnyel is, hogy korlátozott a bejutásra jogosult hallgatók száma az anyaországban. A legnagyobb kihívás a magyar felsőoktatás számára, hogy más diszciplínák esetében is tudjon versenyképes programot, megfelelő szolgáltatást nyújtani.

A harmadik csoportba 22,6\%-kal a más földrészekről érkező hallgatók kerültek. A nemzetközi mobilitási trendektől eltérően (Open Doors 2006, IIE publikációi, NAFSA és EAIE konferenciák) itt kisebb\%-os emelkedés következett be, mint az európai régióban. Irán stabilizálta az első helyét 979 hallgatóval, akik döntő többsége az orvosi képzésben tanul. (Csak összehasonlításként, kb. ennyi magyar hallgató tanul az USA-ban, de jóval változatosabb képzési programokban.) A korábbi években még vezető Izrael stabil, de csökkenő hallgatószámot (743) jelent továbbra is. 2007-hez képest Nigéria, egy afrikai ország került az 5.-ről a 4. helyre, Törökország pedig a 7.-ről a 3. helyre. Ez utóbbi esetében igen rövid időszak alatt 100\%-os növekedés, egyfajta „áttörés” következett be és az 520 fö már tiszteletet parancsoló szám.

Örömteli, hogy Vietnám a 2007-es év (208 fö) után csökkenésnek induló hallgatószámát sikerült megfordítani, és ismét növekvő létszámmal, 227 fővel képviselteti magát. Nagyon lassú a legnagyobb potenciált hordozó kinai diákok számának a növekedése. A 290 fó és az országok rangsorában elfoglalt 13. hely azt jelzi, hogy a magyar egyetemek még nem teljsen értik ennek a piacnak a sajátosságait. Annak ellenére, hogy az elmúlt esztendőben miniszterelnöki látogatásokra került sor, illetve a magyar miniszterelnök stratégiai partnernek tekinti a Távol-Keletet. Itt lenne lehetőség az orvosi mellett más tudományterületeken is hallgatókat toborozni. Kína erőteljesen fejleszti a felsőoktatását, de ennek ellenére nem csökken a külföldön tanuló kínai diákok száma, sőt 2011-ben rekordnagyságot ért el a számuk (Project Atlas 2011). A Koreai Köztársaságból és Szaúd-Arábiából érkező hallgatók száma két év alatt megduplázódott, míg Japánból is majdnem ugyanennyi diák jött Magyarországra tanulni.

Nagy potenciál van Afrika és Ázsia más országaiban is a jövőre nézve. Ennek néhány jelét már most is tapasztalhatjuk, ha a 100 fő alatti létszámú külföldi hallgatót adó országok trendjeit vizsgáljuk. Láttuk, hogy Nigéria a más földrészen található küldő országok között a 4. helyre került. Ígéretes Kamerun, ahonnan 10 éve még egyetlen hallgató sem jött, ma pedig már 70 fö tanul hazánkban (csak viszonyításként, Németországban Kamerun több mint 5000 diákkal vezeti az afrikai országok listáját). Mongólia (59 fö), Kazahsztán (32 fö), vagy Azerbajdzsán (22 fó) jelentős potenciális piac lehet, ha egy-egy egyetem, vagy a kormányzat célzott marketingstratégiát követ. A következő ábrák (12., 13. és 14.) az elmúlt 5 esztendőben dinamikus változást mutató országok, országcsoportok helyzetét mutatják, ahol a körök a hallgatószámot és annak változását reprezentálják. 
12. ábra: A 2006-ban 100 fönél kevesebb, de 2011-ben már ennél több hallgatót küldö, dinamikus növekedést mutató országokból érkező hallgatók számának alakulása (2006-2011)

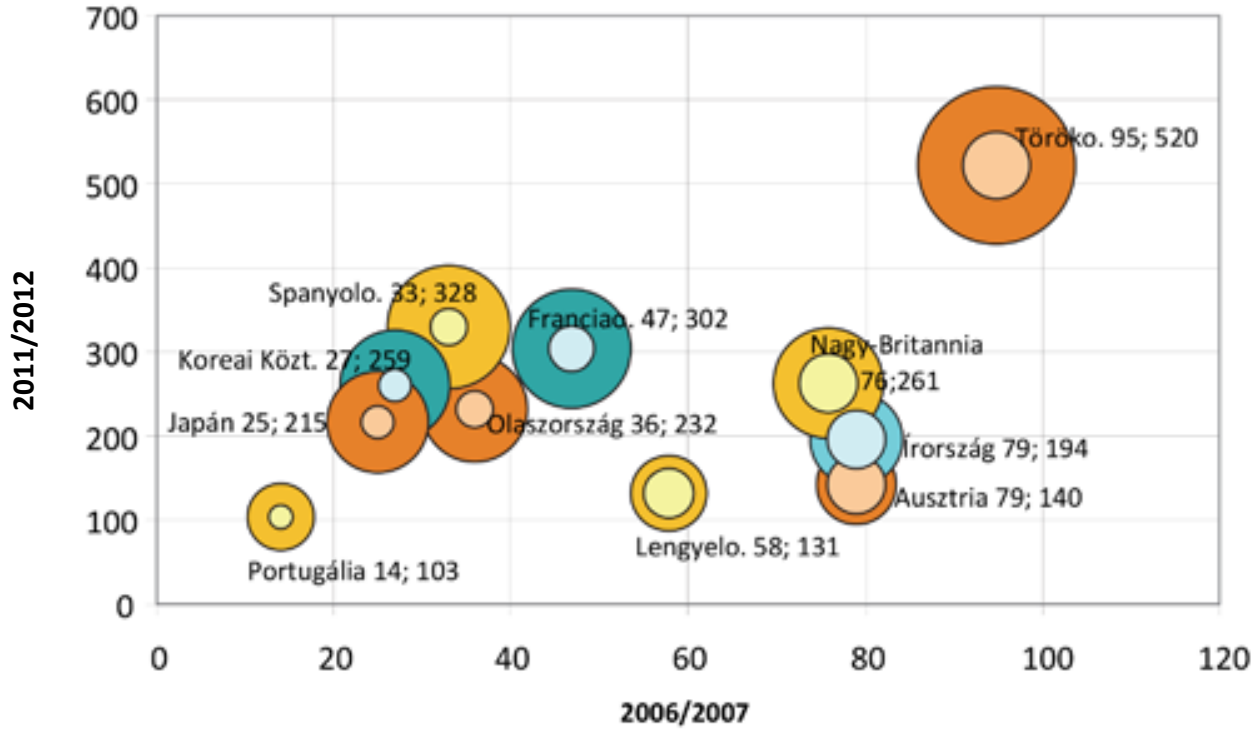

Forrás: Emberi Erőforrások Minisztériuma, felsőoktatási statisztikai adatok alapján saját szerkesztés

13. ábra: A 2006-ban és 2011-ben is 100 fönél kevesebb hallgatót küldő, dinamikusan növekvö európai országokból érkező hallgatók létszáma (2006-2011)

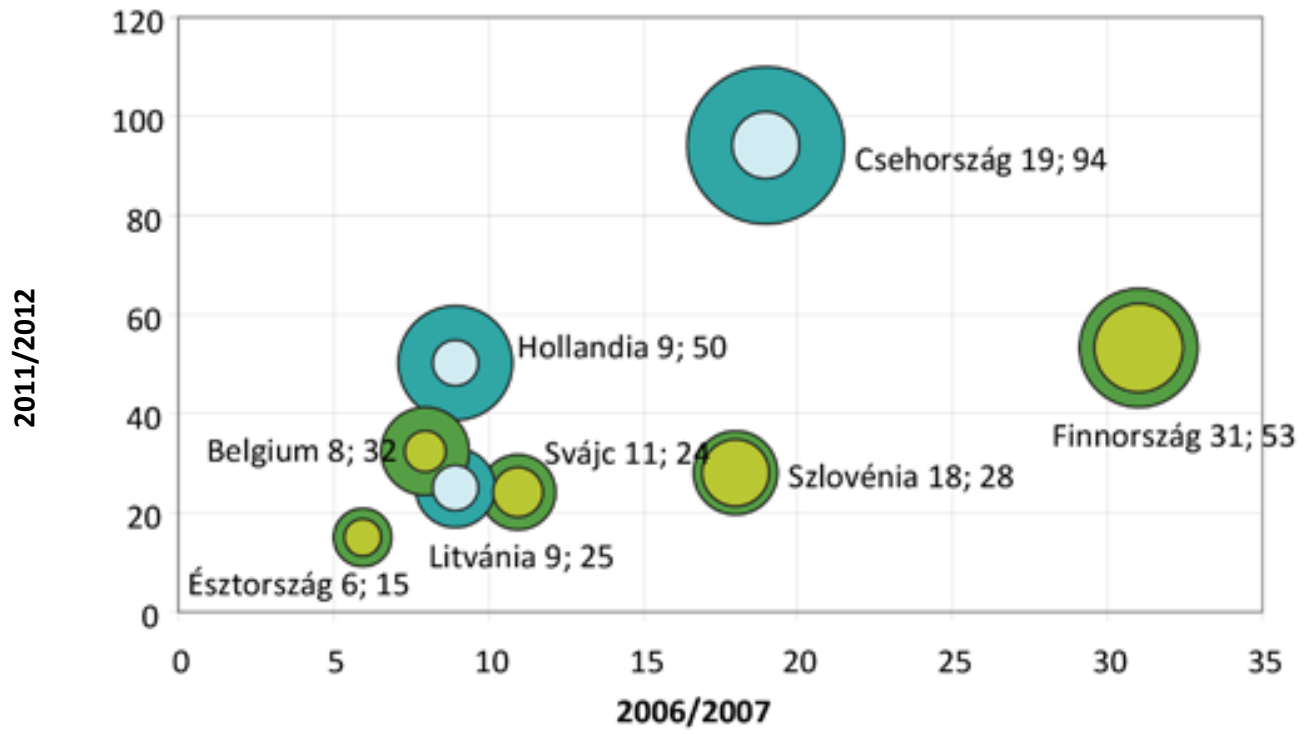

Forrás: Emberi Erőforrások Minisztériuma, felsőoktatási statisztikai adatok alapján saját szerkesztés 
14. ábra: A 2006-ban és 2011-ben is 100 fönél kevesebb hallgatót küldő, dinamikusan növekvö nem európai országokból érkező hallgatók létszáma (2006-2011)

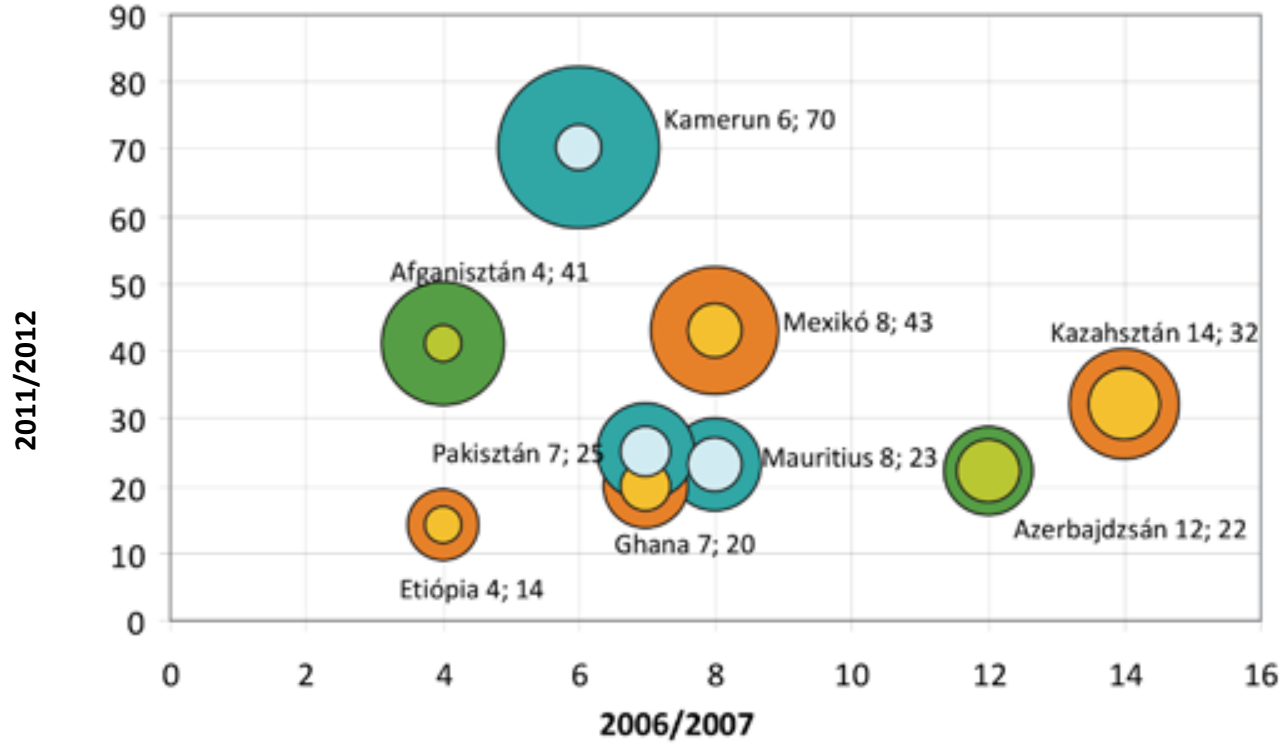

Forrás: Emberi Erőforrások Minisztériuma, felsőoktatási statisztikai adatok alapján saját szerkesztés

15. ábra: A Magyarországon tanuló külföldi hallgatók arányának alakulása, állampolgárság szerint, top 10 ország (2011/2012)

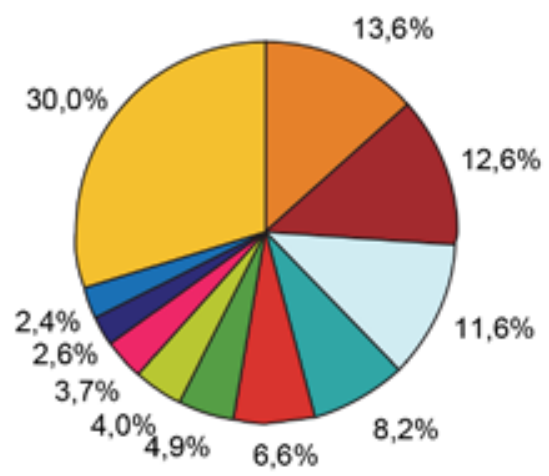

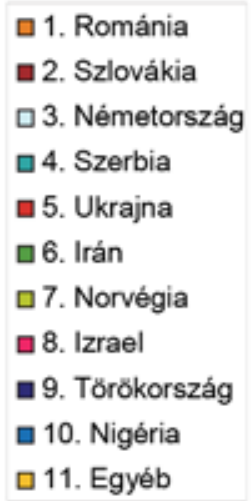

Forrás: Emberi Erőforrások Minisztériuma, felsőoktatási statisztikai adatok alapján saját szerkesztés 


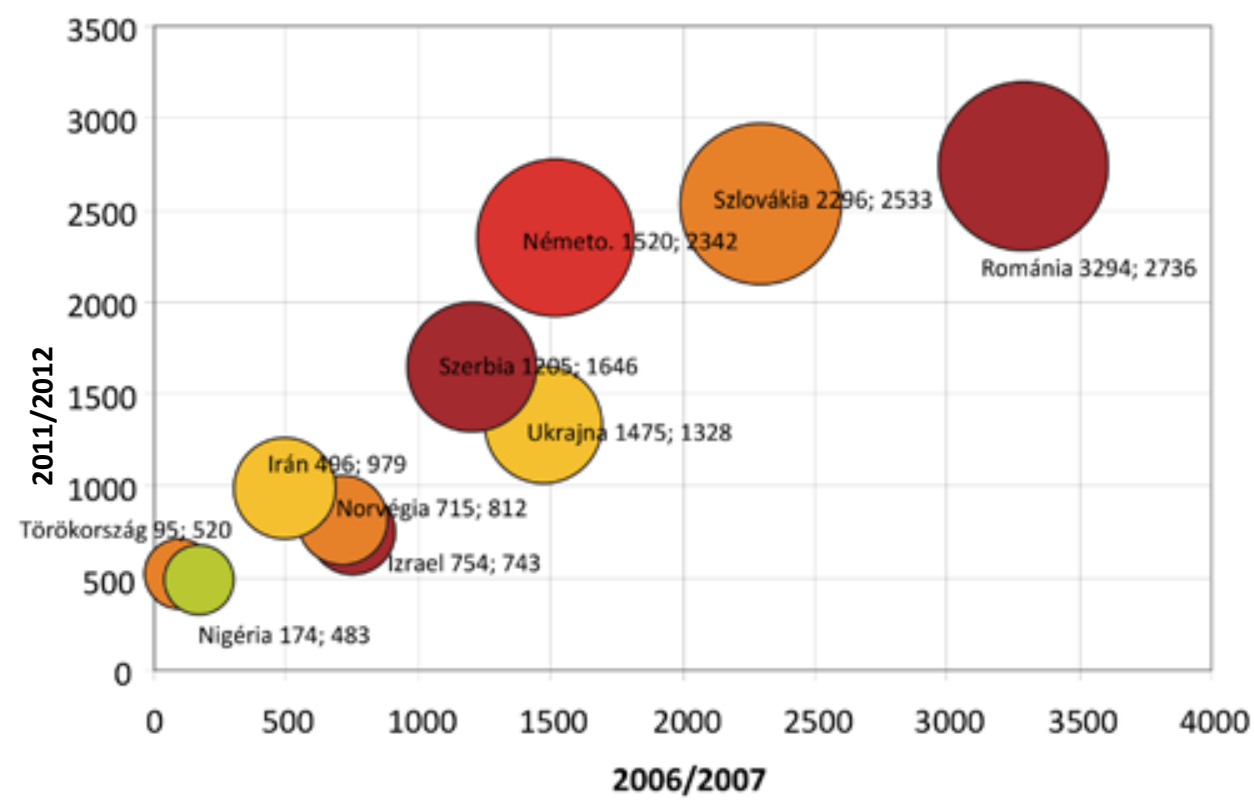

Forrás: Emberi Erőforrások Minisztériuma, felsőoktatási statisztikai adatok alapján saját szerkesztés

Ha a külföldi hallgatók országok szerinti koncentrációját nézzük, akkor először is azt állapíthatjuk meg, hogy ez fokozatosan csökken. A rangsor első 10 helyét elfoglaló országok részesedése a piacból, az ún. C-10 koncentrációs mutató 2006-ban még 81,6\% volt, 2011-re viszont 70\%-ra csökkent (15. ábra). 2006 és 2011 között a top 10 ország kettő kivételével változatlan maradt (16. ábra). 2009-től Nigériának sikerült leszorítania a tábláról Ciprust és belépnie a „300-asok” klubjába. 2011-től pedig Törökországnak sikerült kiszorítania Svédországot, de már az „500-asok” klubjába való belépéssel. Az első 5 ország továbbra is stabilan tartja a helyét, hiszen Ukrajna 349 fővel előzi meg a 6. helyen következő Iránt. Az első 5 ország koncentrációja 2011ben, a C-5 mutató 52,5\% volt, a 2006-os 64,9\%-hoz képest 12,4 százalékponttal alacsonyabb. Más szóval ez azt jelenti, hogy egyfajta kiegyenlítődés indult meg a 6-10. és az alacsonyabb helyen álló országok javára.

Az országok szerinti ilyen mértékü koncentráció azt is indukálja, hogy mind az egyetemek, mind a kormányzat rendelkezzen szegmentált piaci stratégiával ezekben az irányokban. A korábbi egyetemi intézményfejlesztési tervekben (Berács - Hubert - Nagy 2009) nem láttuk ennek nyomait.

\subsection{Külföldi hallgatók az egyes képzési szinteken és képzési formákban}

A Bologna-folyamat eredményeként még mindig egyfajta átmeneti időszakot élünk, azaz egyidejűleg létezik a régi főiskolai és egyetemi szintű képzés, valamint az új alap- és mesterképzés, ez utóbbiak részarányának növekedésével (7. táblázat). Az osztatlan képzés elsősorban az orvosi képzést jelenti a külföldi hallgatók esetében. A mesterképzés fokozatosan veszi át az egyetemi képzés szerepét. A főiskolai szintű képzést már majdnem teljesen átvevő alapképzésben tanul a hallgatók legnagyobb csoportja, $41,4 \%-\mathrm{kal}^{4}$

4 A Bologna-folyamat eredményeként ezt a szintet éri a legtöbb kritika az egyetemek oldaláról, miszerint nincs igazán pozícionálva, nem tudni, hogy a gyakorlatra vagy a továbbtanulásra készít fel. Ez kockázati tényezőt jelent a jövőre nézve, elsősorban a fizetős programoknál. 
A képzési szinteket tekintve, a hallgatók több mint fele tanult az ún. bolognai szisztéma szerint a 2011/2012-es tanévben, míg az OECD 33 tagállamában ez az arány 2010-ben 75\% volt. A szakirányú továbbképzés és a felsőfokú szakképzés csak abban az esetben fog nagyobb szerephez jutni, ha a föiskolák, egyetemek újragondolják és újrapozícionálják a szerepüket, miként azt az új felsőoktatási törvény is sugallja. A felsőfokú szakképzésben a főiskolák, míg a szakirányú továbbképzésben az egyetemek tudnának nagyobb piaci részesedéshez jutni. Ehhez azonban a világ vezető iskoláihoz hasonlóan új, vonzó termékekkel kellene megjelenni. Ugyancsak erre van szükség ahhoz, hogy a mesterképzés aránya (24\%) az alapképzéshez viszonyítva továbbra is emelkedjen. A doktori képzésben a korábbi évek visszaesése után emelkedés következett be, és a 2,7 \%-os részesedéssel már értékelhető nagyságrendű a hazánkban tanuló külföldi hallgatók aránya.

7. táblázat: Külföldi hallgatók a magyar felsőoktatásban, képzési szintek és képzési tagozatok szerint, 2011/2012 tanév

\begin{tabular}{|l|l|l|l|l|l|l|l|l|l|}
\hline Tagozat & $\begin{array}{l}\text { Felsőfokú } \\
\text { szakképzés }\end{array}$ & $\begin{array}{l}\text { Fóiskolai } \\
\text { szintü } \\
\text { képzés }\end{array}$ & $\begin{array}{l}\text { Egyetemi } \\
\text { szintü } \\
\text { képzés }\end{array}$ & $\begin{array}{l}\text { Alap- } \\
\text { képzés }\end{array}$ & $\begin{array}{l}\text { Mester- } \\
\text { képzés }\end{array}$ & $\begin{array}{l}\text { Osz- } \\
\text { tatlan } \\
\text { képzés }\end{array}$ & $\begin{array}{l}\text { Szakirányú } \\
\text { továbbkép- } \\
\text { zés }\end{array}$ & $\begin{array}{l}\text { PhD, } \\
\text { DLA } \\
\text { képzés }\end{array}$ & $\begin{array}{l}\text { Össz. } \\
\text { Nappali }\end{array}$ \\
\hline 192 & 39 & 598 & 6273 & 1607 & 7933 & 52 & 418 & 17112 \\
\hline Esti & 4 & 3 & 1 & 42 & 16 & 1 & 19 & 1 & 87 \\
\hline Levelező & 31 & 35 & 14 & 1964 & 399 & 152 & 140 & 122 & 2857 \\
\hline $\begin{array}{l}\text { Távokta- } \\
\text { tás }\end{array}$ & 0 & 30 & 0 & 83 & 0 & 0 & 7 & 0 & 120 \\
\hline \\
Össz.
\end{tabular}

Forrás: Emberi Erőforrások Minisztériuma, felsőoktatási statisztikai adatok alapján saját szerkesztés

Tanulságos a többi képzési szinteken tanuló hallgatók országok szerinti koncentrációja is. A szomszédos Románia, Szlovákia, Ukrajna és Szerbia hallgatói nagyrészt az alapképzésben vesznek részt. Ha ide veszszük a még főiskolai képzésben szereplő hallgatókat, valamint szembeállítjuk őket az egyetemi szintű, mester és osztatlan képzési szinteken tanuló hallgatók csoportjával, akkor azt látjuk, hogy az első szintű képzésben kb. háromszor annyian vannak, mint a második szintű képzésben. Ennek a megtartása külön stratégiát igényel.

A doktori képzésben tanuló külföldi hallgatók küldő országok szerinti megoszlásában Románia, Szlovákia, Szerbia és Ukrajna vezeti a rangsort, de sokkal nagyobb, jóllehet csökkenő koncentrációval (a C-4 koncentrációs mutató 63,2\%) mint amit az összes hallgatónál tapasztaltunk. További 5 országból érkezett 10-nél több PhD hallgató (Németországból, Iránból, Oroszországból, Olaszországból, Lengyelországból), jelezve, hogy kevés országban van jelentős hírneve a magyar tudósképzésnek. Mindezek az információk segítenek abban, hogy az egyes doktori iskolák kijelöljék a potenciális piacaikat, mert jelenleg eléggé véletlenszerü, hogy honnan jönnek a hallgatók. Az 541 külföldi doktori hallgatóból 494 jött a 100-nál több külföldi hallgatót adó 30 országból. A C-30 koncentrációs muta- 
tó értéke az összes hallgatóra vetítve 93,1\%, amitől a doktori hallgatók C-30-as értéke alig marad el $91,3 \%$-kal.

\subsection{Az Erasmus program keretében megvalósuló magyar diák-, tanár- és személyzeti mobilitás bemutatása}

A diplomát nyújtó képzések mellett nagyon sok hallgató részképzésen tanul külföldön. Ez történhet egyéni alapon, egyetemközi csere és nemzetközi konzorciumok, pl. az Erasmus+ és a CEEPUS révén. A legrészletesebb adatokkal az Erasmus program keretében történő hallgatói, tanári és adminisztratív dolgozói mobilitást illetően rendelkezünk. Ez az a terület, amelyet a programban résztvevő országok miniszterei a Bologna-folyamat keretében 2020-ra megfogalmazott stratégiai célok között számszerűsítve is megjelentettek.

„Felhívunk minden országot a mobilitás növelésére, biztosítva annak magas minőségét, illetve változatosabbá téve a mobilitás típusait és szélesítve hatókörét. 2020-ban az Európai Felsőoktatási Térség végzős hallgatói legkevesebb 20 százalékának kell külföldi tanulmányi vagy képzési tapasztalatokkal rendelkeznie."

(Európa felsőoktatásért felelős minisztereinek nyilatkozata. Leuven és Louvain-la-Neuve, 2009. április 28-29.)

A magyar felsőoktatásban végzetteknek 2010-ben már közel 10\%-a töltött el legalább egy félévet külföldön, így reális célkitűzés ennek megduplázása 2020-ra.

Az Erasmus csereprogram 1987-ben indult Európában, Magyarország 1998-ban csatlakozott hozzá. A 2010/2011-es tanévig bezárólag 2,5 millióan vettek benne részt, közöttük 34210 magyar diák (1,3\%). Miután a diákok többsége egy szemesztert tölt külföldön, ezért a 34210 félévet a 6 féléves alapképzésre átszámítva azt is mondhatjuk, hogy mindezidáig 5 \%16 alapdiplomával egyenértékü képzéshez jutottunk az Erasmus révén.

Ezen a területen Magyarország tartósan külkereskedelmi deficitet mutat fel. A 2010/2011-es tanévben 4140 magyar hallgató tanult külföldön és 3211 külföldi hallgató vett részt magyarországi programokon: az egyenleg -929 fö. Miután az Erasmus programban általában egy félévet töltenek külföldön a hallgatók, ezért ezt a számot osztani kell kettővel, hogy a tanév egészére vonatkozó, teljes idős (full time equivalent) cserehallgató-egyenleget azaz - 465 főt megkapjuk. Ez nem csökkenti jelentősen az export-egyenlegünket, de azért makroszinten is erőfeszítéseket kell tenni a „deficites” külkereskedelmi forgalom kiegyenlítésére. Emiatt is érdekes azt vizsgálni, hogy miként állunk az alábbi szempontok szerint a cserehallgatók tekintetében:

- országok,

- tudományterületek,

- intézmények. 


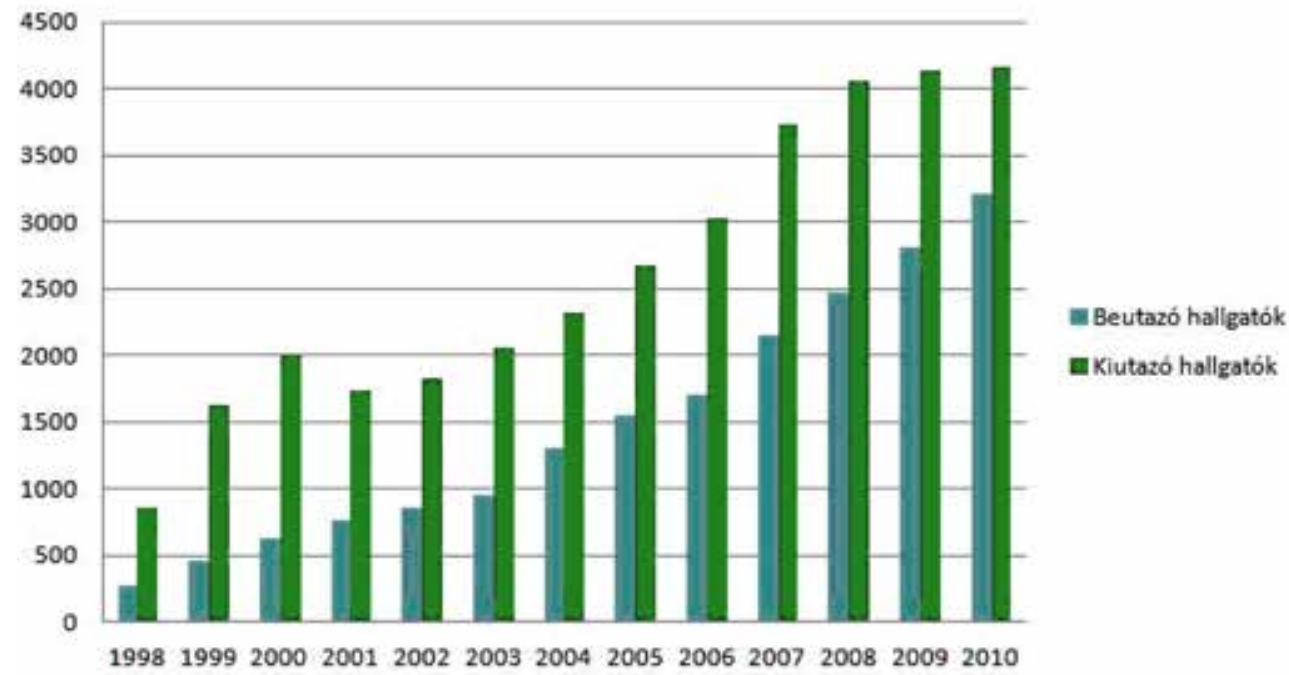

Forrás: http://www.tpf.hu/document.php?doc_name=LLP/Erasmus/Statisztikak/sm_beutazo_orszagonkent1998_2010.jpg

Az 1998-ban induló hallgatói mobilitásban az első években csak a harmadát fogadtuk a kiutazó hallgatóknak (17. ábra), jelezve, hogy nem voltunk eléggé ismertek a külföldi hallgatók számára. Az évtized végére azonban szűkült az olló, részben az angol nyelven kínált programok számának növekedése révén; így a beutazó hallgatók egyenletesen növekedő aránya már elérte a kiutazó hallgatók számának kétharmadát. A 2010/2011-es tanévben kiutazó 4164 hallgató (átlagosan egy szemeszteres kinttartózkodást feltételezve) 2082 hallgató-évnyi oktatási szolgáltatást vett igénybe külföldön.

Az oktatói mobilitás terén (18. ábra) kiegyensúlyozott forgalom valósult meg, érvényesült a kölcsönösség az utóbbi két esztendő magyar kiutazói többletével. Az évi 1080 fős létszám egy hetes átlagos oktatási időtartamból kiindulva, 15 hetes szemesztereket feltételezve, évente már 36 tanár-év oktatási teljesítményt végeznek magyar tanárok külföldön. A kapcsolatépítés szempontjából természetesen ennek sokkal nagyobb a hatása. Az itt tanuló külföldi Erasmus-hallgatók közel 50\%-a jelezte egy kérdőíves kutatásban (Berács - Malota - Zsótér 2010), hogy a tanáraik biztatására választották az adott külföldi országot, egyetemet. Ez a biztatás pedig sokkal erősebb abban az esetben, ha a külföldi tanárok is eljönnek Magyarországra.

Az Erasmus személyzeti mobilitás (19. ábra) később indult és alacsonyabb intenzitású, mint a diák és a tanár kiutazás. A 2010/2011-es tanévben kiutazó 395 fő 46 hetes éves munkaidejével számolva kb. 8 személyzet-év munkaidőt töltött külföldön. 
18. ábra: Erasmus oktatói mobilitás 2000-2010

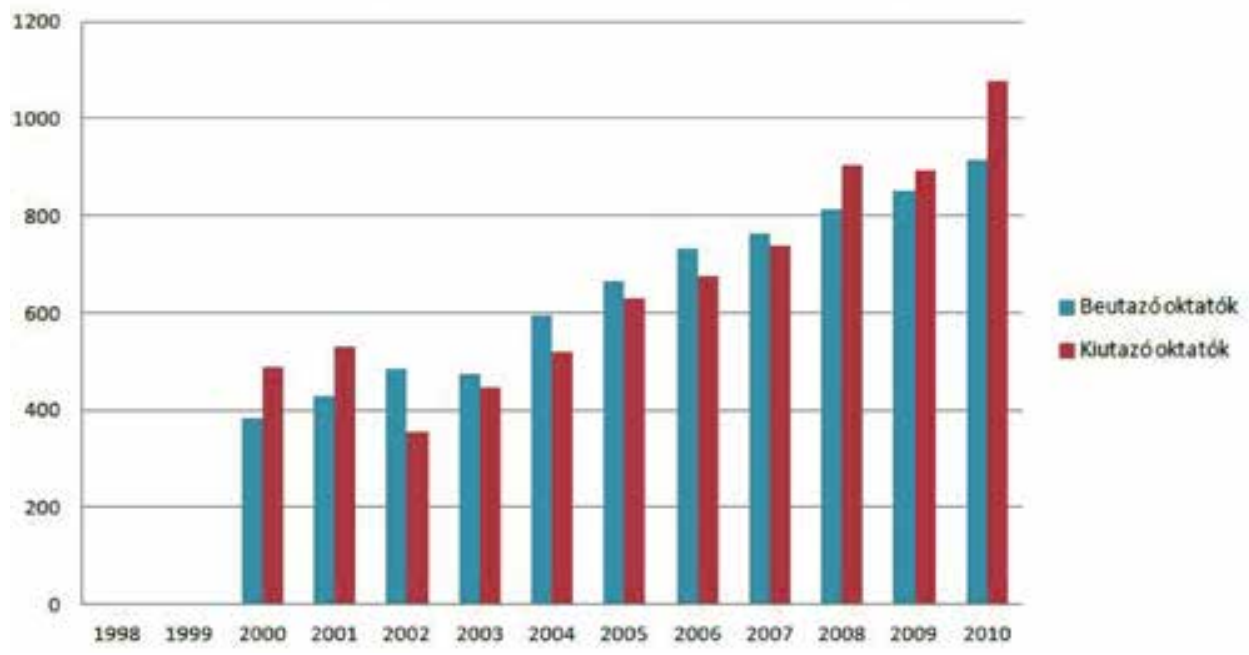

Forrás: http://www.tpf.hu/document.php?doc_name=LLP/Erasmus/Statisztikak/sta_mobilitas_ki be_1998_2010.jpg

19. ábra: Erasmus személyzeti mobilitás 2007-2010

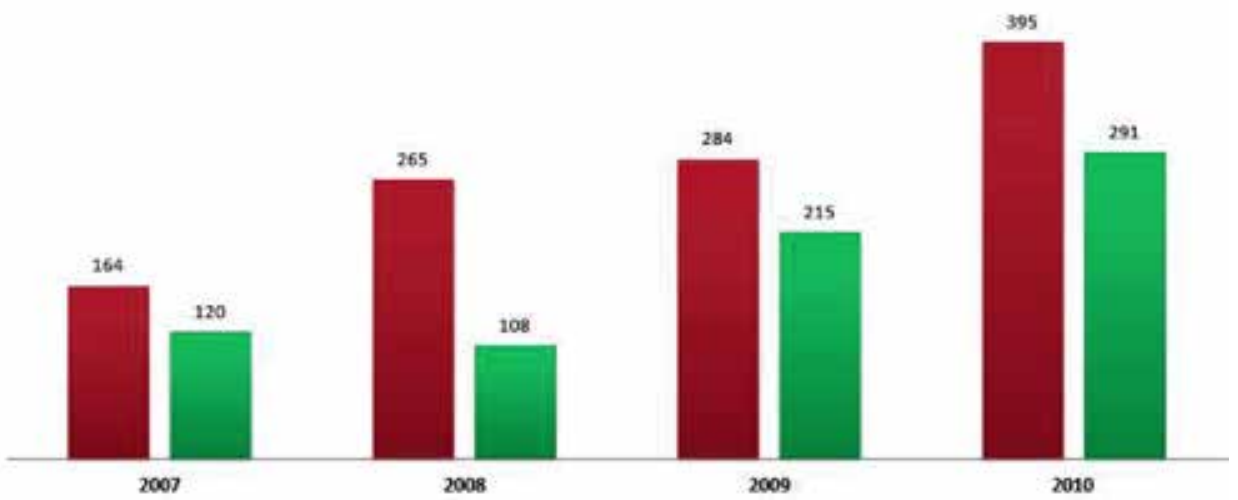

Forrás: http://www.tpf.hu/document.php?doc_name=LLP/Erasmus/Statisztikak/stt_kiutazok_beutazok_2007_2010.jpg 
Annak megítéléséhez, hogy a fenti számok magasak vagy alacsonyak, a foállásban foglalkoztatott létszámadatok arányában való kifejezéssel (az U-Map filozófiát is követve) lehet közelebb jutni. Ezt az arányszámot nevezhetjük az Erasmus programok nemzetközi kitettség mutatójának (a bankszektorban használatos „deviza-kitettségi” mutató mintájára). Mindezt a hallgatókra vonatkoztatva, a teljes időben tanuló hallgatói létszámot kell először meghatározni. A 2009/2010-es tanévben tanuló 242701 nappali hallgatóhoz a 127630 részidős létszám felét hozzáadva (a pénzügyi normatíváknál használatos logikát követve, (Polónyi 2009 alapján is) jutunk a 306516 fös képzett teljes idős (nappali hallgatókkal ekvivalens) létszámhoz. ${ }^{5} \mathrm{Az}$ Erasmus hallgatókra számított nemzetközi kitettség mutató értéke $1 \%$ alatt van, ami azt jelenti, hogy a felsőoktatásban a hallgatók által teljesített kreditek kevesebb, mint 1\%-át teljesítették külföldön, Erasmus keretében.Ugyanilyen logika alapján számolható az oktatói és az alkalmazotti mobilitási kitettségi mutató, amelyre most nem térünk ki.

8. táblázat: Erasmus kiutazó hallgatók 1998-2010 között, a 10 legnagyobb célország szerint (fö)

\begin{tabular}{|c|c|c|c|c|c|}
\hline Sorrend & Célország & $2000 / 2001$ & $2009 / 2010$ & $2010 / 2011$ & $\begin{array}{l}1998 / 1999- \\
2010 / 2011\end{array}$ \\
\hline 1. & Németország & 536 & 930 & 908 & 8491 \\
\hline 2. & Franciaország & 275 & 358 & 336 & 3734 \\
\hline 3. & Olaszország & 205 & 359 & 314 & 3110 \\
\hline 4. & Finnország & 199 & 221 & 198 & 2574 \\
\hline 5. & Spanyolország & 91 & 344 & 398 & 2395 \\
\hline 6. & Hollandia & 145 & 268 & 249 & 2265 \\
\hline 7. & Ausztria & 92 & 242 & 244 & 1908 \\
\hline 8. & $\begin{array}{l}\text { Egyesült } \\
\text { Királyság }\end{array}$ & 135 & 202 & 218 & 1885 \\
\hline 9. & Belgium & 113 & 216 & 223 & 1812 \\
\hline 10. & Dánia & 57 & 96 & 99 & 906 \\
\hline
\end{tabular}

5 Itt nem részletezett durva számítás alapján (Jobbágy 2009 BME-re készített számítását is alapul véve) a felsőoktatásban dolgozó tanárok és személyzet létszámát becsüljük egyaránt 20-20 ezer före. Ez alapján a hallgatók, tanárok, személyzet Erasmus nemzetközi-kitettségi mutatója rendre: $(2082: 306516)=0,675 \%,(36: 20000)=0,18 \%,(8: 20000)=0,04 \%$. Ha nem rendelünk ezekhez a feladatokhoz stratégiai szempontból kiemelt célokat, akkor a normál ügymenet szempontjából ilyen arányú időráfordítást várhatunk el átlagosan az érintettektől. 


\begin{tabular}{|l|l|l|l|l|l|}
\hline $1-10$. & Együtt & 1818 & 3236 & 3187 & 29080 \\
\hline 11-30. & Együtt & 183 & 904 & 977 & 5130 \\
\hline $1-30$ & Összesen & 2001 & 4140 & 4164 & 34210 \\
\hline
\end{tabular}

Forrás: Tempus Közalapítvány honlapján található adatok alapján saját szerkesztés

http://www.tpf.hu/document.php?doc_name=LLP/Erasmus/Statisztikak/sm_celorszagok_2007_2010.jpg

Milyen stratégiai célok rendelhetők az Erasmus program által biztosított nemzetköziesedéshez? Például az, hogy bizonyos országok felé tereljük a magyar hallgatókat, illetve bizonyos országokból ösztönözzük a beutazást. A 8. táblázatban foglaltuk össze az egész időszak alapján legnagyobb 10 célországot. Ugyanakkor azt is látjuk, hogy az elmúlt néhány esztendőben új irányzatok is kezdenek kialakulni. Így pl. megnött Lengyelország, Portugália, Törökország és Svédország vonzereje. Miután a periódus elejéhez képest megduplázódott az érintett országok száma, ezért a 10 országot átfogó koncentrációs mutató a 2000/2001-es tanév 90\%-os értékéről az egész időszakra vetítve 84\%-ra módosult. Vizsgálható lenne, hogy ezek az arányok milyen mértékben vannak összhangban a gazdasági, kulturális, politikai, tudományos, technológiai és egyéb külföldi kapcsolatokkal.

9. táblázat: Erasmus beutazó hallgatók 1998-2010 között,a 10 legnagyobb küldő ország szerint (fó)

\begin{tabular}{|l|l|l|l|l|l|}
\hline Sorrend & Küldö ország & $\mathbf{2 0 0 0 / 2 0 0 1}$ & $\mathbf{2 0 0 9 / 2 0 1 0}$ & $\mathbf{2 0 1 0 / 2 0 1 1}$ & $\begin{array}{l}\mathbf{1 9 9 8 / 1 9 9 9 -} \\
\mathbf{2 0 1 0 / 2 0 1 1}\end{array}$ \\
\hline 1. & Németország & 91 & 425 & 461 & 3239 \\
\hline 2. & Franciaország & 102 & 348 & 397 & 2734 \\
\hline 3. & Olaszország & 88 & 180 & 186 & 1644 \\
\hline 4. & Spanyolország & 45 & 276 & 329 & 1592 \\
\hline 5. & Finnország & 120 & 106 & 107 & 1505 \\
\hline 6. & Törökország & 0 & 333 & 394 & 1435 \\
\hline 7. & Lengyelország & 0 & 233 & 244 & 1028 \\
\hline 8. & Hollandia & 37 & 111 & 139 & 908 \\
\hline 9. & Portugália & 19 & 78 & 96 & 883 \\
\hline 10. & Belgium & & & & \\
\hline
\end{tabular}




\begin{tabular}{|l|l|l|l|l|l|}
\hline $1-10$. & Együtt & 519 & 2207 & 2491 & 15618 \\
\hline $11-30$. & Együtt & 105 & 597 & 720 & 3509 \\
\hline $1-30$. & Összesen & 624 & 2804 & 3211 & 19127 \\
\hline
\end{tabular}

Forrás: Tempus Közalapítvány honlapján található adatok alapján saját szerkesztés

http://www.tpf.hu/document.php?doc_name=LLP/Erasmus/Statisztikak/sm_beutazo_orszagonkent1998_2010.jpg

A Magyarországra érkező hallgatók országok szerinti megoszlását vizsgálva (9. táblázat) azt tapasztaljuk, hogy az első három ország megegyezik a kiutazó hallgatók (8. táblázat) rangsorával. Ezután azonban nagyobb változatosságot tapasztalhatunk az időszak egészére, de különösen az elmúlt évekre vonatkozóan. A legszembetűnőbb különbség az, hogy a fejlődő vagy a közepesen fejlett országokból, illetve a szomszédos országokból is megindult az Erasmus hallgatók beáramlása. Törökország mutatja a legdinamikusabb változást. A 2010/2011-es tanévben már 394 török diák érkezett hozzánk (ezzel Németország és Franciaország után a 3. legnagyobb küldő ország lett) több mint négyszer annyian, mint ahány magyar hallgató választotta Törökországot. Milyen stratégiai célok rendelhetők ehhez a tényhez? Egyrészt törekedhetnénk kiegyensúlyozottságra, azzal a céllal, hogy a kölcsönösen magas diákcsere egy intenzívebb gazdasági kapcsolatnak teremthesse meg a szakemberellátását. Másrészt viszont ismerve azt, hogy a török diákok nagy arányban tanulnak külföldön diplomát nyújtó képzéseken (nálunk is 402 török diák tanult a jelzett tanévben, amellyel a 4. helyet foglalták el Irán, Izrael és Nigéria után a nem európai küldő országok rangsorában), pozitív szinergiára van lehetőség. Az a török hallgató, aki egy félévet töltött az alapképzés során Erasmus program keretében Magyarországon, visszajöhet később a mesterképzésre teljes diplomáért.

Az Erasmus programban különböző mértékben vesznek részt a magyar felsőoktatási intézmények. Az Erasmus nemzetközi-kitettségi mutató nagy szórást mutatna, ha kiszámolnánk mind a 65 intézményre, amely részt vesz a programban. Ez azonban már túlmutat jelen tanulmányunk terjedelmén. Az elemzés számára a 10. táblázatban rangsoroltuk a 15 legnagyobb küldő intézményt.

A felsőoktatási intézmények tudományos teljesítménye alapján besorolt kutatóegyetemek (Eötvös Loránd Tudományegyetem, Szegedi Tudományegyetem, Debreceni Egyetem, Budapesti Műszaki és Gazdaságtudományi Egyetem, Semmelweis Egyetem) ebben a rangsorban rendre az 1., 4., 5., 7., és a 11. helyet foglalják el. A kiváló egyetemi besorolást kapott intézmények (Pécsi Tudományegyetem, Budapesti Corvinus Egyetem, Szent István Egyetem, Pannon Egyetem, Miskolci Egyetem) a rangsorban rendre a 2., 3., 8., 12. és 14. helyhez jutottak. A rangszámok alapján itt is a kutató egyetemek mutatnak jobb helyezést, jóllehet szórással. Az egyetemek közé csupán egy főiskola tudott beintegrálódni, a 6. helyre sorolt Budapesti Gazdasági Főiskola. 
10. táblázat: Kiutazó Erasmus hallgatók számának intézményi rangsora az 1998-2010-esévek alapján (fó)

\begin{tabular}{|c|c|c|c|c|c|}
\hline Rangsor & Intézmény & $2000 / 2001$ & $2009 / 2010$ & $2010 / 2011$ & $\begin{array}{l}\text { 1998/1999- } \\
2010 / 2011\end{array}$ \\
\hline 1. & ELTE & 212 & 516 & 510 & 4083 \\
\hline 2. & PTE & 284 & 377 & 376 & 3629 \\
\hline 3. & $\mathrm{BCE}$ & 132 & 459 & 475 & 3404 \\
\hline 4. & SZTE & 149 & 343 & 307 & 2896 \\
\hline 5. & $\mathrm{DE}$ & 186 & 308 & 227 & 2477 \\
\hline 6. & BGF & $15^{r}$ & 238 & 234 & 2157 \\
\hline 7. & $\mathrm{BME}$ & 119 & 255 & 310 & 2143 \\
\hline 8. & SZIE & 130 & 124 & 137 & 1247 \\
\hline 9. & PPKE & 49 & 158 & 171 & 1150 \\
\hline 10. & Óbudai Egyetem & 69 & 103 & 116 & 986 \\
\hline 11. & Semmelweis Egyetem & 58 & 106 & 125 & 907 \\
\hline 12. & Pannon Egyetem & 74 & 86 & 79 & 852 \\
\hline 13. & $\begin{array}{l}\text { Moholy-Nagy Művészeti } \\
\text { Egyetem }\end{array}$ & 74 & 68 & 55 & 798 \\
\hline 14. & Miskolci Egyetem & 46 & 106 & 99 & 768 \\
\hline 15. & Széchenyi István Egyetem & 35 & 61 & 61 & 595 \\
\hline $1-15$. & Együtt & 1774 & 3408 & 3282 & 28092 \\
\hline $16-65$. & Együtt & 227 & 732 & 882 & 6122 \\
\hline $1-65$. & Összesen & 2001 & 4140 & 4164 & 34214 \\
\hline
\end{tabular}

Forrás: Tempus Közalapítvány honlapján található adatok alapján saját szerkesztés

http://www.tpf.hu/document.php?doc_name=LLP/Erasmus/Statisztikak/sm_kiutazok_intezmenyenkent_98_2011.pdf 
A számok mögé nézve az a kérdés is felmerül, hogy milyen szakterületek vannak nagyobb arányban reprezentálva a diákcserében? Miként a 20. ábrából látszik, a 2010/11-es tanévben a társadalomtudományok, az üzleti és jogi képzési terület $48 \%$-ot fed le. Ez a szakterületi arány magyarázatot ad arra is, hogy miért a BGF és a KJF főiskolák kerültek be a legutóbbi tanévben a top 15-be. A népszerü turizmus szakok hallgatói számára követelményként is elő lehetne írni a külföldi tanulmányokat. A második helyen a bölcsészettudományok és a művészetek állnak, és csak ezt követik a műszaki tudományok. Az egészségügyi ágazatok alacsony aránya (5,2\%) talán azért meglepő, mert az orvosi képzések adják a fizetős külföldi hallgatók 80\%-át. Az egyetemek bevételre koncentráló stratégiája azonban nem engedi érvényesülni a nemzetköziesedés szempontjából kiaknázható szinergiákat.

20. ábra: Hallgatói kiutazó mobilitás szakterület szerint (2010/2011)
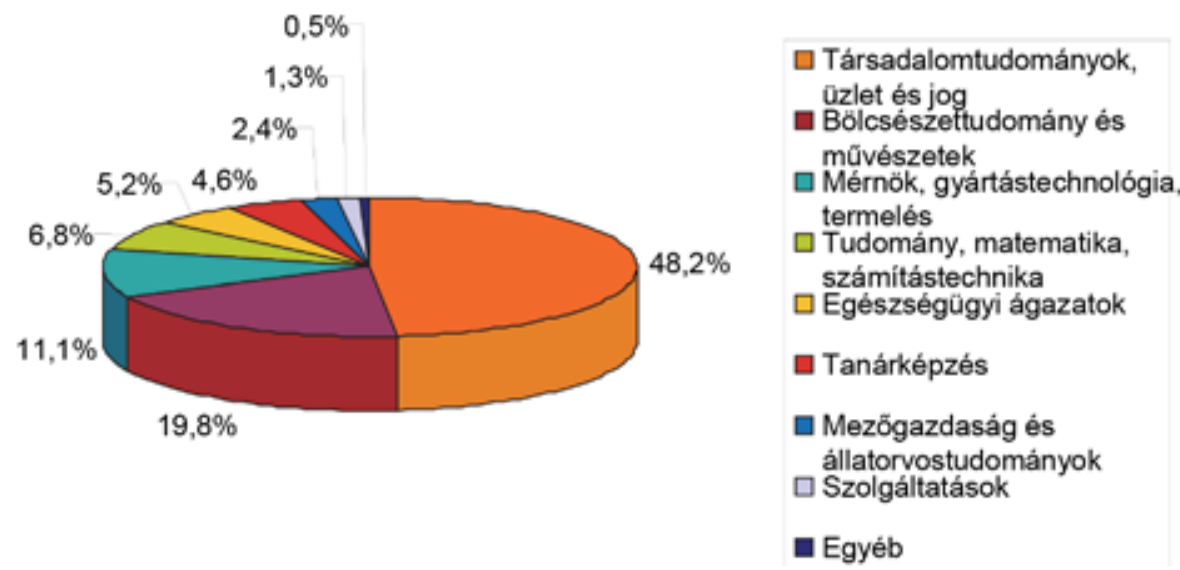

Forrás: Tempus Közalapítvány honlapján található adatok alapján saját szerkesztés

http://www.tpf.hu/document.php?doc_name=LLP/Erasmus/Statisztikak/sm_kiutazok_szakterulet_nem_2007_2010.pdf

Az egyetemi tanulmányok mellett az Erasmus program lehetőséget nyújt arra is, hogy a hallgatók szakmai gyakorlatot szerezzenek külföldön. A 2010/2011-es tanévben mintegy 600 fö dolgozott 15 országban ilyen konstrukcióban. Elsősorban Németországba, Spanyolországba, az Egyesült Királyságba, Görögországba, Ausztriába és Olaszországba utaztak ilyen céllal hallgatóink.

\subsection{Külföldi hallgatók véleménye Magyarországi tartózkodásukról}

Sajnálatos módon nem készül rendszeresen, azonos módszertanra támaszkodva felmérés arról, hogy a külföldi hallgatók miként szereztek információt Magyarországról, az egyetemekről, a programokról. Hogyan vannak megelégedve az itt kapott szolgáltatással, milyen hírünket viszik a világba? Ezen a helyzeten is próbált változtatni a Tempus Közalapítvány és a Bologna sorozat 8. köteteként megjelent tanulmány (Berács - Malota - Zsótér 2011). Egy korábbi hasonló vizsgálattal is összehasonlítva (Berács - Malota 2011) egyértelműen kiderült, hogy akik keveset tudtak előzetesen Magyarországról, azok nagyobb arányban nem választanák újra Magyarországot, mint azok, akik előzetesen sokat tudtak az országról (11. táblázat). 
11. táblázat: Az elözetes információk szerepe abban, hogy a hallgató újraválasztaná-e hazánkat (százalék)

\begin{tabular}{|l|l|l|l|l|l|l|}
\hline \multirow{2}{*}{ Előzetes informáltság/újraválasztás } & \multicolumn{2}{l}{$\begin{array}{l}\text { Újra Ma- } \\
\text { gyarországot } \\
\text { választaná }\end{array}$} & $\begin{array}{l}\text { Lehetséges, hogy } \\
\text { Magyarországot } \\
\text { választaná }\end{array}$ & \multicolumn{2}{l|}{$\begin{array}{l}\text { Nem választaná } \\
\text { úja } \\
\text { Magyarországot }\end{array}$} \\
\cline { 2 - 9 } & 2004 & 2010 & 2004 & 2010 & 2004 & 2010 \\
\hline Előzetesen sokat tudott az országról & $\mathbf{5 7}$ & $\mathbf{7 y}$ & 40 & 21 & 3 & 2 \\
\hline Valamit tudott az országról, de nem sokat & 50 & 54 & 40 & 35 & 10 & 11 \\
\hline Nagyon keveset tudott az országról & 29 & 54 & 59 & 33 & 12 & 12 \\
\hline
\end{tabular}

Forrás: Berács - Malota 2011, 229. o.

Megjegyzés: 2004-ben a minta 43\%-a 2010-ben a minta 58\%-a választaná újra Magyarországot

A kérdőív egyik leglényegesebb, szintetizáló jellegü kérdését illetően azt az eredményt kaptuk, hogy 2010-ben a megkérdezett külföldi diákok jelentős hányada (58\%) ha ismét választania kellene, újra Magyarországot választaná a célból, hogy itt tanuljon reguláris, illetve csereprogram keretében. 32\% talán ismét ide jönne tanulni, és mindössze $10 \%$ gondolja úgy, hogy a választása nem esne Magyarországra.

2004-ben a hazánkat biztosan újraválasztók aránya jóval alacsonyabb volt (43\%), a 2010-es adatokhoz hasonlóan $10 \%$ volt biztos abban, hogy nem jönne újból hozzánk tanulni, a bizonytalanok aránya pedig $47 \%$-os volt.

Mivel magyarázható ez az elmúlt hat év alatt tapasztalt javuló tendencia?

A kutatásunkban 13 tényező (indikátor) alapján vizsgáltuk a hallgatók elégedettségét. A 21. ábra egyértelműen mutatja, hogy az elégedettségi skálán minden egyes tényező esetében magasabb átlagértéket adtak a 2010-es felmérés résztvevői a 2004-es felmérés megkérdezetteihez képest. A másik szembetűnő jelenség, hogy a tényezők relatív megítélése nem sokat változott a 6 év alatt. Szinte mindig szignifikáns kapcsolatot találtunk az elégedettséget mérő skálák és az újból Magyarországon tanulást választók aránya között. Minél elégedettebb a hallgató a közlekedési feltételekkel, vásárlási és szálláslehetőségekkel, a tandíj összegével, az egyetemi/főiskolai ügyintézéssel, az egyetemi könyvtárral és infrastruktúrával, a tanáraival és diáktársaival, tanárai angoltudásával valamint az oktatás módszereivel és színvonalával (ez utóbbi két változó csak a 2010-es felmérésben szerepelt), annál nagyobb a valószínűsége, hogy újból hozzánk jönne tanulni. 
21. ábra: Az egyes lehetöségekkel/szolgáltatásokkal való elégedettség a 2004-es és a 2010-es felmérés eredményei alapján (átlag ötös skálán)

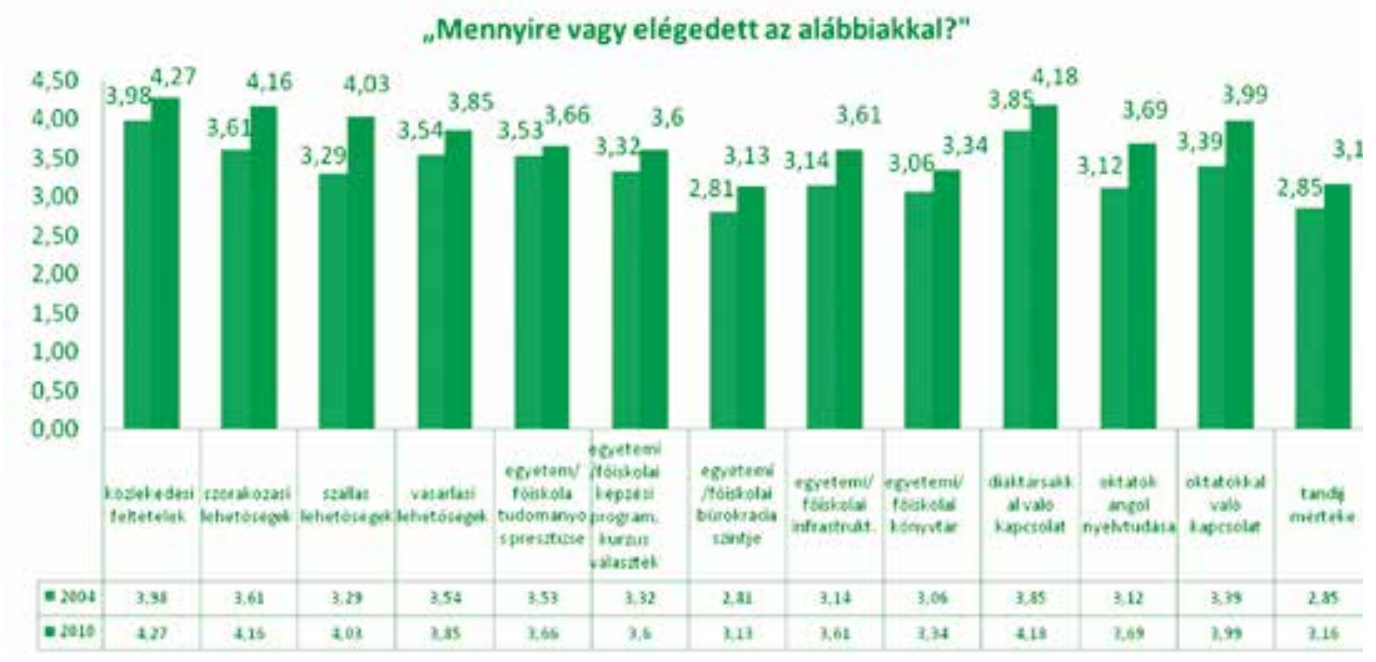

Forrás: Berács - Malota 2011, 223.

A 2010-es felmérés adatai alapján a külföldi hallgatók továbbra is leginkább a közlekedési feltételekkel elégedettek országunkban (4,27-es átlag ötös skálán mérve), a válaszadók 83\%-a az inkább elégedett vagy nagyon elégedett kategóriát jelölte meg. A kollégisták a legelégedetlenebbek a közlekedési feltételeket illetően (3,97), a bérelt lakásban vagy házban élők pedig a leginkább elégedettek (4,40 és 4,60). A 2004-es adatok szintén ezt mutatják, a kollégiumban/diákszállón lakók szignifikánsan felülreprezentáltak voltak a nagyon elégedetlenek között. E véleményekben valószínűleg az tükröződik vissza, hogy míg a bérelt lakhelyeket közlekedési szempontok alapján is választják, a kollégium helyszíne adott, és sok esetben nem felel meg maradéktalanul ezen elvárásoknak. A kollégiumokban jórészt (a mintát illetően 88\%-ban) cserediákok laknak, így a diákszállások helyszínének kiválasztása és színvonalának növelése e célcsoport szempontjából lényegesebb.

2010-ben a szórakozási lehetőségek elégedettségi mutatója szintén magas, a megkérdezettek mintegy 79\%-a a közepesnél elégedettebbnek vallja magát, a szálláslehetőségekkel pedig a válaszadók háromnegyede elégedett vagy inkább elégedett. A vásárlási lehetôségekkel elégedett a megkérdezettek $68 \%$-a. Legkevésbé a sportolási lehetőségeket tartják kedvezönek a hallgatók, 46\%-uk csak közepesen vagy a közepesnél kevésbé elégedett.

A budapesti hallgatók tartják legkedvezőbbnek a közlekedési feltételeket, a szórakozási és vásárlási lehetőségeket, a vidékiek viszont elégedettebbnek érzik magukat a szállás- és sportolási lehetőségeket illetően.

Ország-fejlettségi kategóriánként nézve az átlagokat, szembetűnő, hogy a vásárlási lehetőségekkel a fejletlenebb országokból származó diákok elégedettebbek, a sportolási lehetőségeket legkevésbé a legfejlettebb országokból érkezők tartják megfelelőnek.

Leginkább azok választanák újra hazánkat, akik a legelégedettebbnek vallják magukat a szállás-, a vásárlási, a közlekedési és a sportolási lehetőségeket illetően, mindkét felmérés során statisztikailag szignifikáns kapcsolat mutatható ki e változók között. 


\section{Lehetőségek és tervek a külföldi hallgatók vonzására}

A külföldi hallgatók Magyarországra vonzásának alapvető feltétele, ha a szomszédos országok magyar anyanyelvü állampolgáraitól eltekintünk, hogy az akadémiai programokat idegen nyelven is hozzáférhetővé tegyük. A felsőoktatásért felelős kormányzati szervek időről időre megjelentetnek kiadványokat az elérhető programokról, de nincs olyan kiadvány, amely katalógusszerűen, évről évre beszámolna a programokról. Ennek hiányában, a 2012-ben az állami felsőoktatási intézményekben elkészített intézményfejlesztési tervek (IFT) szolgálnak forrásként. Ebből tudhatjuk meg, hogy a magyar egyetemek miként közelítik meg az olyan további stratégiai kérdéseket, mint a nemzetközi hálózatok felhasználása, országstratégiák kidolgozása, bilaterális és multilaterális kapcsolatok fejlesztése, stb. Az IFT készítése hatalmas szellemi munka, amely nagy része sajnos kevésbé hasznosul, illetve mivel döntően központi megrendelésre készült, ezért kevésbé hatja/hatotta át az intézmények mindennapi életét. A rendelkezésre álló adattáblákból, illetve a több ezer oldalt kitevő szöveges értékelésekből ${ }^{6}$ elsősorban a nemzetközi területre vonatkozó információkat elemezzük, a tanulmányunk terjedelme és témaköre által meghatározott kereteken belül.

\section{1. Idegen nyelvű képzések és szakok a magyar felsőoktatási intézményekben}

Az idegen nyelvű képzés nem csupán a külföldi, hanem a magyar hallgatók számára is fontos. Egyrészt azért, mert előkészíti a külföldi utat, másrészt azok számára, akik nem fognak kijutni külföldre, belföldön teremti meg a nemzetközi környezetet. A vizsgált 27 intézmény adatai alapján, akikre vonatkozóan rendelkeztünk intézményfejlesztési tervekkel, illetve az IFT mellékletét képező statisztikákkal, megállapítható, hogy a domináns nyelv az angol. 2011-ben kb. négy és félszer annyian tanultak angol nyelven, mint a második helyen szereplő német nyelven (22. ábra). Minden további nyelv stagnált az elmúlt két évben. Néhány egyetem speciális kapcsolatok, vagy egyéb személyes indíttatás révén hirdet meg francia vagy más nyelven tantárgyakat vagy teljes programot. A Szegedi Tudományegyetemen egyedi, 100 millió forintos kormánytámogatással öt év alatt kell felépíteni egy „francia egyetemet”, hasonlóan az Andrássy Gyula Német Nyelvü egyetemhez.

A vizsgált 27 egyetem közül az Intézményfejlesztési Tervében 6 intézmény nem számolt be egyetlen idegen nyelven meghirdetett szakról sem. Az ötnél kevesebb idegen nyelvű szakot elindító 10 egyetem adja a legnagyobb csoportot. A 22. ábrán feltüntetett további 11 intézményből 6 egyetem rendelkezett 20nál is több idegen nyelven müködő szakkal. A két legtöbb idegen nyelvü szakot működtető intézmény a Szegedi Tudományegyetem (38 szak), illetve a Liszt Ferenc Zeneművészeti Egyetem (47 szak). A müvészeti egyetemeken megfigyelhető kis létszámú szakok az SZTE érintett karain is megjelennek, ezáltal biztosítva az előkelő második helyet a rangsorban.?

6 Az Intézményfejlesztési Terv kidolgozásához az intézmények megkapták az Oktatáskutató és Fejlesztő Intézet megbízásából, az IFUA Horváth \& Partners Vezetési és Informatikai Tanácsadó Kft által készített, „Stratégiaalkotás a felsőoktatásban: Módszertani kézikönyv" című 266 oldalas dokumentumot. Emellett megkapták az Excelben kitöltendő táblázatok listáját. Ily módon volt olyan intézmény, ahol 1500 oldalt tett ki a teljes IFT dokumentum. Mindezidáig nem készült az IFT-kről átfogó, publikus elemzés, jóllehet a minisztérium értékelte őket és ezeket is felhasználva döntött a „,kiemelt intézmény”, a „kutatóegyetem, kutató kar”, illetve az „alkalmazott kutatások főiskolája” cím odaítéléséről. A fenntartó minisztérium által elkészített „Kézikönyv az Intézményfejlesztési Tervek értékeléséhez" címü 62 oldalas dokumentum szerint készített szakértői jelentések és pontszámok (mint egyfajta audit) is hasznos forrásul szolgálhatnának a kutatók és az intézmények számára.

7 A Diplomás Pályakövetési Rendszer 2011. évi felmérése szerint, 46000 hallgató válasza alapján legalább alapszintű nyelvtudásról a következő arányban számoltak be: angol (91\%), német (64\%), francia (14\%), olasz (11,5\%), orosz (10,6\%), spanyol (9,4\%). A külföldi tanulmányokon átlagosan a megkérdezettek 5,6\%-a vett részt, legmagasabb arányban a művészeti képzési terület (17,7\%) és a pedagógusképzés $(12,6 \%)$, legalacsonyabb arányban a természettudományi (2,7\%) és a műszaki képzési terület (2,8\%) hallgatói. http:// www.felvi.hu/hallgatoknak/tanulas/kevesen_tanulnak_kulfoldon?itemNo2 
Az idegen nyelvű szakok lehetőséget teremtenek külföldi egyetemekkel közös képzésekre, közös diplomák, oklevelek kiadására. Jóllehet több uniós irányelv is ösztönzi a „joint degree” kiadását, ez csak nagyon vontatottan halad az intézményi és nemzeti szabályozások miatt. Az IFT-kben sem sikerült ezt pontosan körülírni, és erre is visszavezethető, hogy a 24. ábrán nagyon nagy eltéréseket találunk. Az első helyen szereplő BCE 21 ,joint degree jellegü" együttműködése azt jelentené, hogy egy kivételével minden meghirdetett idegen nyelvű szak (23. ábra) ilyen rendszerben működik, ami nem valószínű, illetve értelmezési problémára vezethető vissza. Ugyanakkor a magas számok kifejezik a szándékot a szorosabb együttműködésre a külföldi partnerekkel. Az Erasmus szerződések kiindulópontjai lehetnek a tartós kapcsolat ilyen irányú fejlesztésének.

22. ábra: Idegen nyelvü képzésben részt vevő hallgatók létszáma

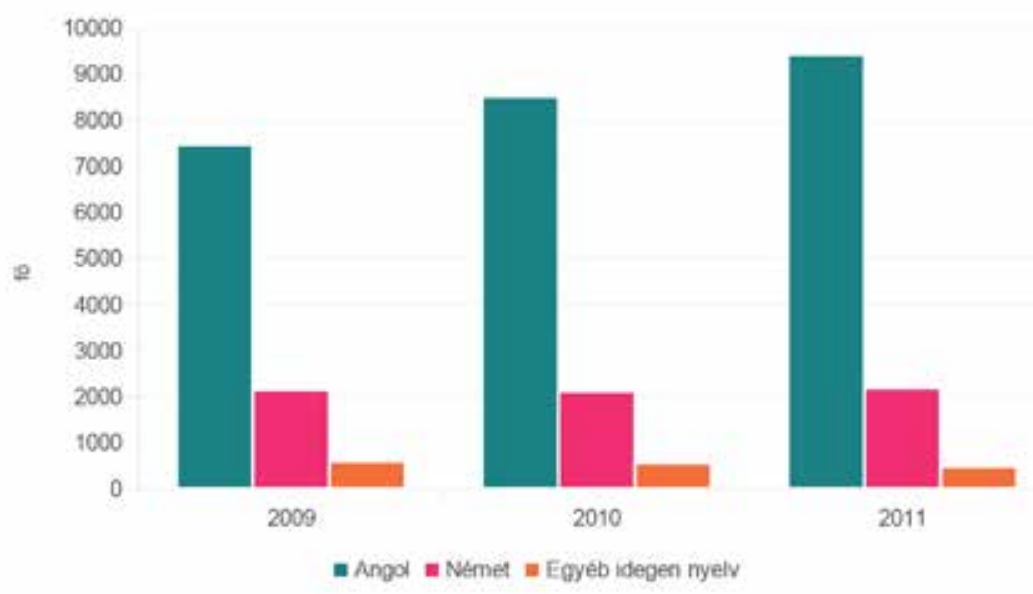

Forrás: femip.hu oldalon elérhető 27 állami felsőoktatási intézmény IFT-je. TABL_11

23. ábra: Ötnél több idegen nyelvü szakot meghirdetett egyetemeken a meghirdetett idegen nyelvü szakok száma (2011)

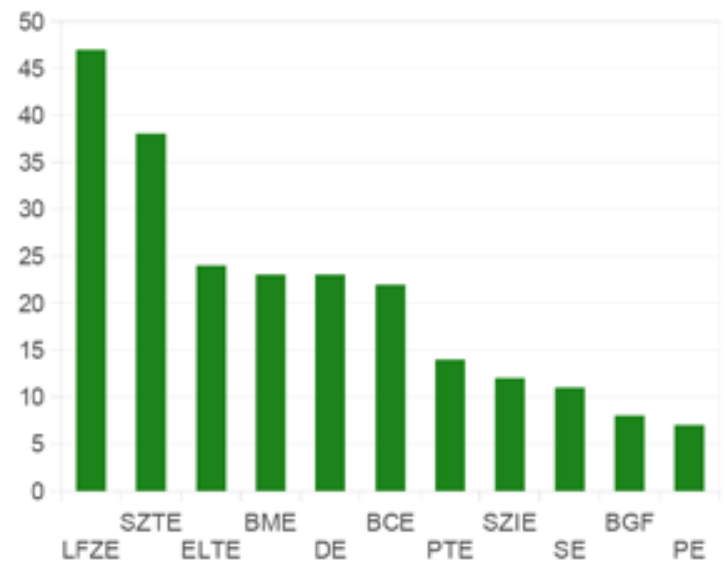

Forrás: femip.hu oldalon elérhető 27 állami felsőoktatási intézmény IFT-je. TABL_17 
24. ábra: Joint degree jellegü, közös képzési együttmüködések száma (2011)

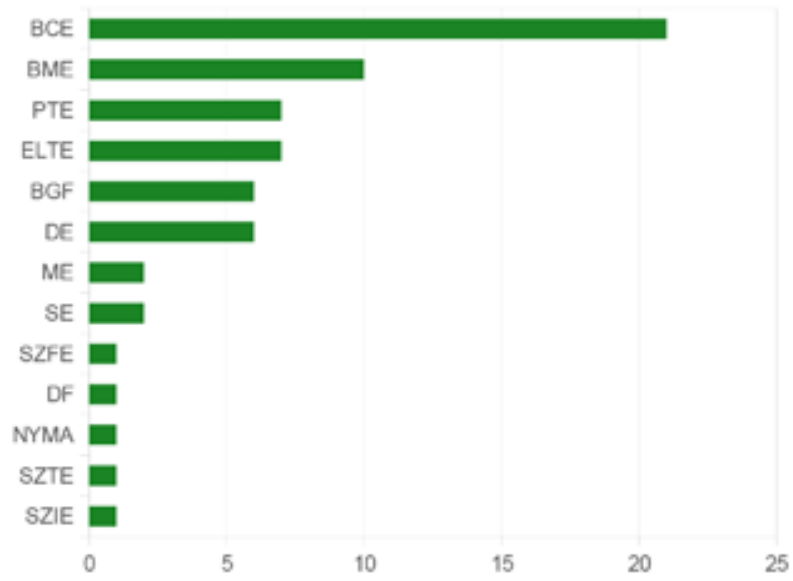

Forrás: femip.hu oldalon elérhető 27 állami felsőoktatási intézmény IFT-je. TABL_17

25. ábra: Angol nyelvü képzésben részt vevő hallgatók létszámának változása a vizsgált intézményekben

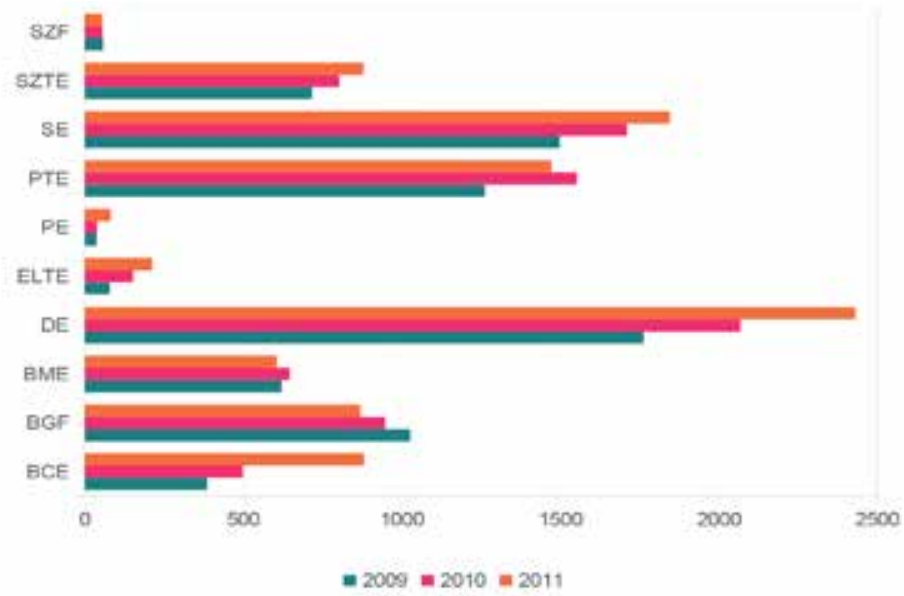

Forrás: femip.hu oldalon elérhető 27 állami felsőoktatási intézmény IFT-je. TABL_11

$\mathrm{Az}$ angol nyelv szinte minden mást félresöprő dominanciája a szakokat illetően a vizsgált, rövidnek nevezhető hároméves időintervallumon is számottevően (73\%-ról 78\%-ra) emelkedett. Az angol nyelvű képzésekben - azoknál az egyetemeknél, amelyek ilyen jellegű képzést nyújtanak - szinte kivétel nélkül a hallgatói létszám növekedése jellemző a 2009-2011 közötti időszakban. 2009-ről 2010-re és 2010-ről 2011-re csupán a BGF számolhatott be csökkenésről, ezen kívül két intézménynél volt még az egyik évben visszaesés tapasztalható, a többi egyetemen azonban kifejezetten magas növekedésről beszélhetünk (25. ábra). Ennek fényében nem meglepő, hogy a vizsgált időszakban az angol nyelvű 
képzésekben részt vevők száma dinamikusan nőtt: 2009-ben 7 474, 2010-ben 8 512, míg 2011-ben már 9418 hallgató tanult angol nyelvű szakokon (22. ábra). Ez két év alatt összesen 26\%-os bővülésnek felel meg.

A következő vizsgált kérdés az angol nyelvü képzésben részt vevő hallgatók finanszírozási forma szerinti megoszlása. Ebbe a vizsgálatba csak azokat az egyetemeket vettük be, ahol legalább egy angol nyelvü szakot sikerrel el tudtak indítani. A 4.5. ábrán az angol nyelvű képzésben részt vevő hallgatók finanszírozási forma szerinti megoszlását az önköltséges hallgatók arányával jellemeztük. Hat intézményben szinte kizárólag (a Debreceni Egyetemnél 99\%-ban) önköltséges formában tanultak a hallgatók angol nyelven. A másik példa a Pannon Egyetem, ahol 2011-re jelentősen visszaesett az államilag finanszírozott hallgatók aránya. Ebben az esetben a képet némileg árnyalja az angol nyelvű képzésben részt vevők alacsony létszáma (2009: 38 fó, 2010: 39 fo, 2011: 83 fó), ám külön aláhúzandó, hogy az adatok alapján 2009-ről 2011-re az idegen nyelvű hallgatók létszáma 218\%-kal emelkedett, és ez a növekedés szinte kizárólag az önköltséges hallgatók létszámbeli emelkedésének tudható be. Ellentétes trendet egyedül a Müszaki Egyetem esetében figyelhetünk meg.

Gyakori probléma, hogy a külföldön tanuló hallgató tantárgyait az ekvivalencia hiánya miatt a küldő intézmény tanárai, illetve a kreditátviteli bizottság tagjai nem ismerik el. Nem mindenki azonosul azzal a liberálisabb állásponttal, hogy "mindegy, hogy mit, de színvonalas tárgyat” tanuljon külföldön a diák. A 27. ábrán a kreditelismert tanulmányok száma szerepel, ami összhangban áll a korábban tárgyalt Erasmus kiutazásokkal, jóllehet nem sikerült a fogalmat pontosan meghatározni. Általános cél, hogy a külföldön teljesített kurzusokat teljes értékű kreditként fogadja el a küldő intézmény.

26. ábra: Önköltséges hallgatók aránya az angol nyelvü képzésben (2011)

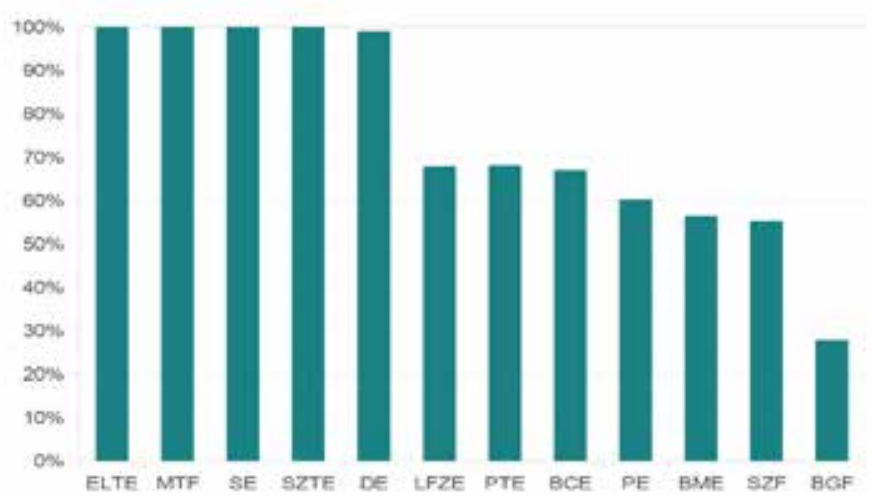

Forrás: femip.hu oldalon elérhető 27 állami felsőoktatási intézmény IFT-je. TABL_11 


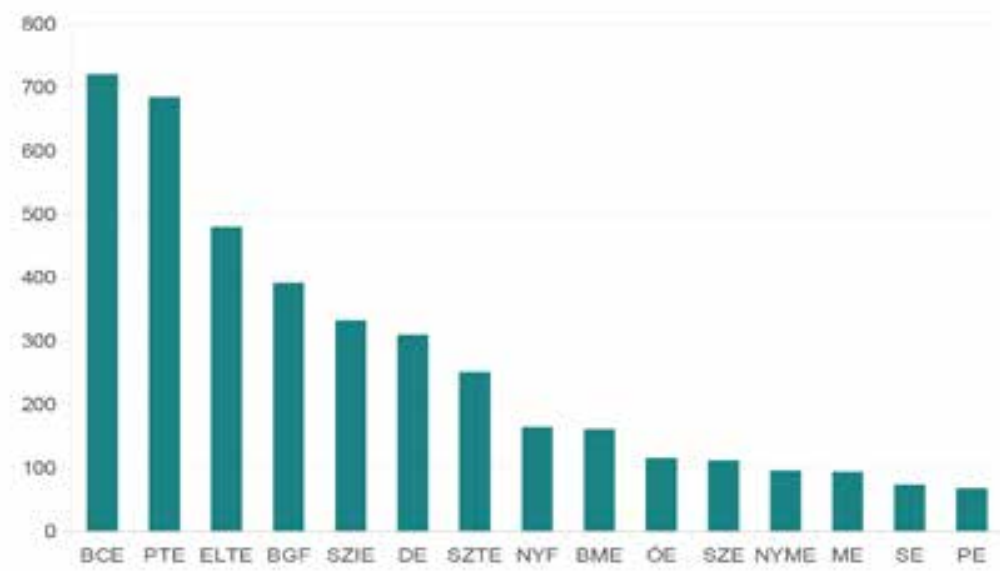

Forrás: femip.hu oldalon elérhető 27 állami felsőoktatási intézmény IFT-je. TABL_17

\subsection{Forgatókönyvek a külföldi hallgatók számának 2020-ig várható alakulására}

Mi várható 2020-ra? Ha az elmúlt évtized növekedése folytatódik, akkor lineáris trendet feltételezve évente 800 fővel fog nőni a külföldi hallgatók száma, így 2020-ra elérheti a 27000 főt. Amennyiben optimista feltételezéssel élünk, és azt gondoljuk, hogy:

a) a globalizáció és az EU erőteljesebb nemzetköziesedést diktál, (ez jelent meg a célokban és a deklarációkban)

b) az oktatási kormányzat stratégiai kérdésnek tekinti ezt az ügyet

c) az egyetemek és főiskolák a túlélésük és a nemzetközi versenyképességük érdekében kiemelten kezelik ezt a témát, (szórványosan vannak rá példák, ha az orvosi képzéstől eltekintünk),

akkor reális lehetőség van 2020-ra megduplázni, azaz 40000 före emelni a külföldi hallgatók számát. Optimistább forgatókönyvek is készíthetők, ha nagy gazdasági makro összefüggésekbe helyezzük a témát, és egy igazi felzárkózást biztosító gazdasági növekedést vizionálunk egymillió új munkahellyel 2020-ra. Ekkor a felsőoktatás stratégiai szerepét tekintve húzóágazat lehet, és a kb. 260000 főre apadó magyar hallgatói kör mellett akár 60000 fö is lehet külföldi. (Emlékezzünk, ez kb. annyi amennyi külföldi hallgató tanult Ausztriában 15 esztendővel korábban. ${ }^{8}$ ) Egyidejűleg azonban legalább 30000 magyar állampolgárságú diák tanulhat külföldön. (2013-ban a számuk kb. 14000 főre tehető).

A kutatói és hallgatói migráció (L. Rédei 2011) a globalizáció hatására fokozódni látszik, és ebben Magyarország a hallgatói fogadás oldaláról az élen jár. 2006-ban a világ országai között a külföldi hallgatók abszolút száma alapján képzett rangsorban az előkelő 23. helyet foglaltuk el (Open Doors 2006), a GDP

8 Ezzel „csak” egy 15 éves lemaradást konzerválnánk a szomszédos Ausztriához képest, vagy felvennénk a globális növekedés ritmusát, ami egy nyitott ország számára elsősorban a „nemzeti” iparágak számára elengedhetetlen. Példák bőségesen vannak nagy ugrásokra. Rajika Bhandari, az IIE kutatási igazgatója sok példát hoz az ilyen „szokatlanul” nagy célértékekre. Pl. Japán 120000 főrő 2025 -re 1 millióra kívánja emelni a külföldi hallgatók számát. Impozáns növekedést tűzött ki célul Jordánia, Kína, Malajzia és Szingapúr is (Bhandari 2009). 
alapján számított helyezésnél kedvezőbb pozíciót. 60000 külföldi hallgató kiszolgálása háromszor annyi munkaerőt jelent, mint a mostani közel 24500 fóé. Ha a 35000 új diák kiszolgálásának teljes költségét, munkaerőigényét nézzük, akkor 20 före egy-egy oktatót és egyéb szolgáltatót számítva, csak a felsőoktatásban 4000 új munkahely teremtődhet, vagy őrződhet meg. Ehhez már a kormány a KKV-k számára az Új Széchenyi Tervben nyújtott támogatáshoz hasonló összeget nyújthatna a felsőoktatási intézmények számára is. Természetesen ez kis szám a megcélzott egymillió új munkahelyhez képest, de tovagyürűző hatását tekintve egyáltalán nem elhanyagolható. Ugyanis a külföldi hallgatók költési szerkezete olyan, hogy minden 1 forint tandíjhoz legalább 1 forint egyéb költés társul, az itt tartózkodásra, megélhetésre, lakásra, stb. Ez alapján további 4000 új munkahely teremtődhet az országban külföldi piaci forrásból. A 12. táblázatban, a demográfiai változásokat is figyelembe véve, három lehetséges forgatókönyvet vázolunk fel a külföldi hallgatók számára vonatkozóan.

12. táblázat: Külföldi hallgatók fogadásának forgatókönyvei 2020-ra (Hallgatói létszám alternatívák az adott esztendő októberében, különböző stratégiai erőfeszitések mellett)

\begin{tabular}{|l|l|l|l|l|l|}
\hline $\begin{array}{l}\text { Időszak } \\
\text { Stratégiai } \\
\text { erőfeszítés }\end{array}$ & $\begin{array}{l}\text { Diplomaszerző } \\
\text { külföldi hallga- } \\
\text { tók száma }\end{array}$ & $\begin{array}{l}\text { Csere- } \\
\text { hallgatók } \\
\text { száma }\end{array}$ & $\begin{array}{l}\text { Összes } \\
\text { külföldi } \\
\text { hallgató } \\
\text { száma }\end{array}$ & $\begin{array}{l}\text { Magyar- } \\
\text { országi } \\
\text { hallgatók } \\
\text { száma }\end{array}$ & $\begin{array}{l}\text { Összes } \\
\text { hallgató a } \\
\text { felsőoktatásban }\end{array}$ \\
\hline $2011 / 12$ & 20176 & 2500 & 22676 & 337000 & 360000 \\
\hline $2012 / 13$ & 21000 & 3000 & 24000 & 306000 & 330000 \\
\hline $\begin{array}{l}\text { 2020/21 } \\
\text { Trend } \\
\text { extrapoláció }\end{array}$ & 30000 & 5000 & 35000 & 260000 & 295000 \\
\hline $\begin{array}{l}2020 / 21 \\
\text { Közepes } \\
\text { erőfeszítés }\end{array}$ & 40000 & 7000 & 47000 & 260000 & 307000 \\
\hline $\begin{array}{l}\text { 2020/21 } \\
\text { Nagy } \\
\text { erőfeszítés }\end{array}$ & 50000 & 10000 & 60000 & 260000 & 320000 \\
\hline
\end{tabular}

1. A tanévben előforduló cserehallgatók száma kétszerese a táblázatban szereplőnek

2. Külföldön tanuló magyar hallgatók száma 2020-ban: diplomaszerző: 20 000, cserehallgató: 10000. Mindösszesen 280000 före becsüljük a felsőoktatásban tanuló magyar hallgatók számát, mert a cserehallgatókat egyszer vesszük számításba. 


\section{Fejlesztési területek}

\subsection{Stratégiai irányok, programfejlesztési lehetőségek}

A tanulmány előző fejezeteiben felvonultatott információk és érvek alapján kívánjuk megfogalmazni a fejlesztési területekre vonatkozó javaslatainkat. Így például az orvosi képzés, ahol már minden második hallgató külföldi, valószínűleg 2020-ig eléri befogadó képességének maximális határát. A fejlett országokban legnépszerűbb gazdasági, üzleti, bölcsész képzés területén azonban még nagyon sok lehetőség van a programok fejlesztésére. A viszonylag élen járó Budapesti Corvinus Egyetem is megtöbbszörözheti külföldi tandíjas hallgatóinak számát, miként az ELTE is. A Miskolci Egyetem, a Pécsi Tudományegyetem vagy a Pannon Egyetem közgazdasági, üzleti karain pedig 10-szeres növekedésre lehet, kell számítani, ha fel akarnak zárkózni az intézmények a nemzetközi élmezőnyhöz. Ehhez az intézmények falai közé be kell vinni a piackutatást és a marketing tevékenységet. Az intézmények felkészitése konkrét akciótervet igényel, amelyben nem csupán a külföldi, hanem a hazai tapasztalatokra is célszerü támaszkodni.

A Debreceni Egyetem érte el az elmúlt 7 esztendőben a legnagyobb növekedést a külföldi hallgatók vonzásában. 2011 decemberében már 3300 külföldi hallgató tanult a cívis városban. Ez háromszor több mint 2004-ben volt. Országos rekorderként már nemzetközi szinten is figyelemre méltó eredményt mutat. Véleményünk szerint a következő 7 évben országos szinten is megismétlődhet a debreceni példa, és a 2005ös ausztriai adatokhoz hasonlóan Magyarország is fogadhat 60000 külföldi hallgatót 2020-ban. A negatív demográfiai trend, valamint a költségtérítéses képzések kiterjesztése innovatívabb tevékenységet követel a felsőoktatás vezetőitől ahhoz, hogy a felsőoktatási kapacitásokat kihasználják, és a foglalkoztatást továbbra is biztosítsák. Ezért van szükség a korábban tárgyalt mutatószámokra, piaci indikátorokra, viszonyszámokra, amelyek a nemzetközi piacorientációt szolgálják, és egyben kiutat mutatnak a költségvetési megszorításban élő, de saját erejére támaszkodni szándékozó felsőoktatási intézményeknek.

Ilyen horderejü változás nem képzelhető el jelentős állami szerepvállalás nélkül. Az egyetemek arculatát megváltoztató külföldi hallgatók nem élhetnek izoláltan. A magyar hallgatók idegen nyelvtudását, miként az oktatókét, sokkal magasabb szintre kell helyezni. A tanulmány végén szereplő feladattervben igyekszünk az előző fejezetekben meghatározott nemzetköziesedési indikátorok célértékeihez igazodó teendőket felvázolni. Így pl. nem elég (de nagyon fontos) az egyetemre bekerülő hallgatók nyelvvizsgára való felkészültségének folyamatos nyomon követése, hanem szükség van az idegen nyelven hallgatott tárgyak kreditértékeinek növelésére. Ha kitűztük, hogy a végzett diákok 20\%-a töltsön el legalább egy félévet külföldön, akkor ki kell tűzni például, hogy a végzett diákok 80\%-a tanuljon legalább egy tárgyat idegen nyelven, vagy $40 \%$ szerezzen az egyetemén legalább 30 kreditet idegen nyelven. Ezek a számok szakonként és egyetemenként természetesen változhatnak. A turizmus szakokon sokkal magasabb célértéket kell kitűzni, illetve megkövetelni a kormányzati szándékok alapján is az outputra jobban koncentráló nemzeti akkreditációnál.

További szempont, hogy a nemzetközi rangsorokban (AWRU, Financial Times, THES, Webometrics, $\mathrm{CHE)} \mathrm{kedvezőbb} \mathrm{helyet} \mathrm{foglaljanak} \mathrm{el} \mathrm{a} \mathrm{hazai} \mathrm{felsőoktatási} \mathrm{intézmények.} \mathrm{Ezekben} \mathrm{a} \mathrm{rangsorokban} \mathrm{álta-}$ lában figyelembe vesznek olyan paramétereket, mint külföldi hallgatói, vagy külföldi oktatói arány. Az ezeknek való megfelelés az intézményi vezetéstől komoly erőfeszítéseket követel. Annak ellenére, hogy sok kritika éri ezeket a rangsorokat (Török 2006), egyre nagyobb szerepet töltenek be az intézmények életében, egyre több intézmény használja ezeket a versenyben elfoglalt pozíciójának illusztrálására.

A felsőoktatás sokféleségével foglalkozó kutatás az európai U-Map modell, az egyetemek csoportosítását egy széleskörű indikátorrendszerre alapozva kívánja elvégezni (Hrubos 2012). A kutatók beemelték a nemzetközi orientációt, mint önálló dimenziót a felsőoktatási intézmények feltérképezési rend- 
szerébe. Ezzel az oktatás, a kutatás, a tudástranszfer, és a regionális elkötelezettség mellett megjelent a nemzetköziség is, mint az intézmények tevékenységének egyik fontos eleme. Remélhető, hogy ez hozzájárulhat ahhoz, hogy a nemzeti oktatási kormányzatok és a felsőoktatási intézmények nagyobb figyelmet fordítsanak a nemzetközi orientáció kérdésére, és gazdagodni fog a témával kapcsolatos rendszeres adatgyüjtés (európai szinten is).

Az U-Map modellben az intézmények tevékenységének egy-egy dimenzióját néhány kiemelt mutatóval írják le, olyanokkal, amelyek egyfelől tömören jellemzik az adott dimenziót, másfelől az adatok is rendelkezésre állnak. A magyar modellben a következő indikátorok szerepelnek, amelyeknél feltüntettük a Magyarországra vonatkozó 2010-es adatokat is:

\begin{tabular}{|l|l|}
\hline E/1 A külföldi, fokozatszerző hallgatók aránya az összes hallgatón belül, nappali tagozat (\%) & $7,5 \%$ \\
\hline $\begin{array}{l}\text { E/2 A csereprogramok keretében beérkezö hallgatók aránya az összes hallgatón belül, nap- } \\
\text { pali tagozat (\%) }\end{array}$ & $0,6 \%$ \\
\hline $\begin{array}{l}\text { E/3 A csereprogramok keretében kiutazó hallgatók aránya az összes hallgatón belül, nappali } \\
\text { tagozat (\%) }\end{array}$ & $1,1 \%$ \\
\hline E/4 Külföldön tartózkodók aránya az akadémiai stábban (\%) & $0,4 \%$ \\
\hline \begin{tabular}{l} 
E/5 Külföldi állampolgárok aránya az akadémiai stábban (\%) \\
\hline E/6 A nemzetközi bevételek aránya a teljes K+F bevételen belül (\%)
\end{tabular} & $1,5 \%$ \\
\hline
\end{tabular}

Ezek elsősorban arányszámok, amelyek mellett nagyon sok információ rejtve marad. Első ránézésre is nyilvánvaló, hogy ágazati szinten egyedül a külföldi fokozatszerző hallgatók nappali tagozaton belüli 7,5\%-os aránya ébreszthet figyelmet. A többi érték az „ingerküszöb”alatt van, ráadásul nagy szórással. A külföldről származó $\mathrm{K}+\mathrm{F}$ bevételek $80 \%$-a két intézményhez, a Budapesti Műszaki Egyetemhez és a Debreceni Egyetemhez kötődött (Polónyi 2009). A nemzetközi egyetemi klasztert két, idegen nyelven oktató magán intézmény, a Közép-európai Egyetem (CEU) és az Andrássy Gyula Német Nyelvű Egyetem jeleníti meg.

Az U-Map első fázisa az egyetemek fenti dimenzióinak tartalmi és mérési problémáira összpontosított és elsősorban osztályozási, csoportosítási célt szolgált. Az EU által finanszírozott és 2013. január 31-én elindított második szakaszában az U-Multirank már a jelentkező 500 egyetemet rangsorolni is kívánja. Fontos lenne több magyar egyetemnek is felkerülni erre a listára, amelyet először 2014-ben publikálnak.

\subsection{Marketing, piackutatás}

Komplex marketingstratégia kidolgozására van szükség miként pl. a turizmus, a mezőgazdasági termékek, illetve a borok esetében. A jelenlegi értékesítési adatokból indirekt módon következtethetünk a hallgatói szükségletekre, igényekre, keresletre. Ez azonban nem elégséges a jövőbeli ígéretes piacok feltárásához. Szükség van az itt tanuló hallgatók véleményének rendszeres megkérdezésére, a szolgáltatással való elégedettség és elégedetlenség okainak feltárására. Mindezek segítenek a termék, az oktatási 
tevékenység továbbfejlesztésében, a kommunikációs eszközök alkalmazásában, a tandíjak és költségtérítések nagyságának meghatározásában, az értékesítés, mint pl. az ügynöki rendszer fejlesztésében, egy szóval a marketing-mix kidolgozásában.

A szokványos marketing tevékenységek mellett nagy jelentősége van a külföldi egyetemekkel kiépített stratégiai kapcsolatoknak azokban az országokban, ahonnan nagyobb számú hallgatót kívánunk toborozni. Magyarország neve kevésbé ismert, miként az egyetemeké, ezért bizalmat kell építeni, amit a jelenlét növelésével lehet elérni. Ennek sokféle formája lehet. Szaúd-Arábia esetében például megfigyelhető az erős kormányzati kapcsolat, kölcsönös miniszterelnöki, miniszteri látogatás, amely során a felsőoktatás és a kutatás kiemelt szerepet kapott. A szaúdi kormányzat 2012-ben az éves költségvetésének 24,9\%át fordította oktatásra, az emberi tőke képzésére, 21\%-kal többet, mint az előző évben. Az Abdullah Király Ösztöndíj Program (KASP), amely a második 5 éves szakaszába lépett, olyan társadalmat segít felépíteni, amelyben a tudás és az információ jelenti a gazdasági növekedés fö motorját. Jelenleg a KASP ösztöndíj segítségével több mint 125000 szaúdi diák folytat felsőoktatási tanulmányokat a világ legjobb egyetemein. A szaúdi Felsőoktatási Minisztérium 2010-ben rendezte meg először a Felsőoktatási Nemzetközi Kiállítást és Konferenciát, amely három év múlva az egyik legjelentősebb felsőoktatási eseménnyé nőtte ki magát, mind méretében, tartalmában és globális kiterjedésében. 2012-ben már 486 élenjáró egyetem vett részt rajta 39 országból, 42\%-uk Európából érkezett. A rendezvény vízióját, küldetését és célkitűzéseit olvasva, nem kétséges, hogy a magyar egyetemek egy részének is érdemes részt vennie.

A marketingstratégia kialakításánál a nemzetközi piacra lépés fejlődési modelljét érdemes figyelembe venni. Az első és a leggyakrabban alkalmazott módszer a külföldi hallgatók idevonzása, az ún. egyszerü export. A külföldi hallgatók többsége így tanul Magyarországon. Ebben a formában nagy jelentősége van az ügynöki rendszernek, hiszen autentikus módon kell megnyerni egy izraeli vagy nigériai diákot, hogy a világ sok országának több ezer egyeteme közül éppen minket válasszon. A magyar egyetemek nagyon eltérő gyakorlatot követnek abból a szempontból, hogy mennyire nyitottak az ügynökeik megnevezését, a velük kapcsolatos információk megosztását illetően. A BME például az angol nyelvű katalógusában felsorolja az összes (42) ügynökének a nevét és elérhetőségét, míg más egyetemeken még központilag sem rendelkeznek ilyen címlistával. Vannak országok (pl. Kína) ahol a nagykövetségek ajánlást adnak azon ügynökök számára, akiket megbízhatónak tartanak, ezzel könnyítve meg az adott országban partnert kereső egyetemek feladatát. Ez a kérdés más országban is vitatott, miként az Angliában vezető University of Nottingham példája mutatja, akik a teljes nyitottságot választották, még azt is közölve, hogy átlagosan az egy éves tandíj $10 \%$-át fizetik ki ügynöki jutalékként, amivel piacszabályozó szerepet is betöltenek.

A fejlődés második szakaszába sorolhatjuk azokat a változatos megoldásokat, amikor az egyetem egy külföldi országban található egyetemmel oktatási, kutatási szerződést köt, kihelyezett tagozatot szervez, franchising megállapodást hoz létre, diploma elismerési megállapodást köt, közös online kurzust szervez, illetve bármilyen további formában a tanárok, kutatók, adminisztratív alkalmazottak export jellegü tevékenységét helyezi a középpontba, ahol a munkavégzés telephelye már áttevődhet külföldre is.

A fejlődés harmadik, legmagasabb szakaszában az oktatás teljes mértékben külföldre települ, a külföldi egyetem (campus) alapítására kerül sor. A Nottinghami Egyetem angliai telephelye (campusa) mellett, ahol több mint 7000 külföldi hallgató tanul, az első külföldi egyetemét Malajziában hozta létre, ahol már 6000 diák végez tanulmányokat. Ennél is ambiciózusabb terv alapján 2003-ban Kínában elsőként hoztak létre egy teljesen külföldi egyetemet, a „University of Nottingham Ningbo, China” intézményt. Már a következő tanévben, 2004-ben 254 hallgatót fogadtak, majd egy évvel később felépült a 4000 hallgató fogadására alkalmas infrastruktúra, amelyet négy év múlva, a 2008/2009-es tanévben már 90\%-ban sikerült feltölteni. Egy ilyen vállalkozás nagyon céltudatos stratégiát igényel, a helyi (kínai) viszonyok alapos ismeretét, megbízható üzleti partnert, valamint együttműködést az állami intézményekkel (Ennew-Fujia 2009). Mindez 
azonban nyitva áll a magyar egyetemek számára is, azzal a különbséggel, hogy még tudatosabb előzetes piaci felmérésre van szükség, még inkább fontos az állami szerepvállalás, hiszen a magyar egyetemek más helyzetben vannak az emberi erőforrások tekintetében és a pénzügyi lehetőségek terén. Ez is indokolja, hogy együtt tárgyaljuk az intézményi felkészítést és az állami szerepvállalást, amely Vietnámban majdnem elvezetett a Budapesti Corvinus Egyetem és Magyarország első ázsiai campusának a megszületéséhez.

\subsection{Intézményi felkészítés és állami szerepvállalás}

A felsőoktatási intézmények vezetőinek, beosztott munkatársainak, ha nemzetközi versenyképességre törekednek, úgy kell dolgozniuk, mint a multinacionális cégek vagy a diplomáciai testületek munkatársainak. Nem véletlen, hogy Ausztrália vagy Szingapúr egyetemein volt nagyköveteket, sikeres vállalati menedzsereket is találunk az egyetemi vezető pozíciókban, mint dékán vagy nemzetközi igazgató. Értelemszerűen hasonlóan vonzó fizetésekkel, munkakörülményekkel. Magyarországon a Magyar Tudományos Akadémia úttörő szerepet játszik abban, hogy tehetséges fiatal kutatókat kiemelt bérezéssel kutatócsoport megalapításához segít („Lendület program”). Ugyancsak egyedi törekvés, hogy évente 4-5 nemzetközi hírü kutatót hív meg, kiemelt juttatást, költségtérítést fizet, hogy hónapokig nálunk dolgozzanak. A 2013-ban itt dolgozó kutatók havi költsége átlagosan 2,5 millió forint, sok egy egyetemi professzori fizetéshez képest, de megéri a kutatóintézet számára. Hasonló programokat a magyar egyetemek is indíthatnának, állami szerepvállalással, bármilyen pozíció kapcsán (vezető, kutató), ahol ennek eredménye a külföldi hallgatók számának növekedésében is megjelenne.

A humánerőforrás növelését szolgálhatja az a lehetőség, amit a DAAD nyújt a nyugdíjkorhatárt elért professzorok számára, akik szívesen dolgoznának tovább fejlődő országok egyetemein. ${ }^{9}$ Néhány hónapos vagy féléves oktatásra, kutatásra nyílik így lehetőség német professzorok számára pl. Magyarországon is, a fogadó intézmény számára ingyenesen. „Csupán” helyet és vonzó akadémiai környezetet kell nyújtani. Ennek mintájára egy ösztöndíjprogram támogathatná a nyugdíjkorhatárt elért professzorokat abban, hogy a nyugdíj mellett külföldi egyetemeken tanítsanak és kutassanak, azokon a külföldi egyetemeken, amelyekkel a magyar egyetemeknek stratégiai szövetségük van, és amely országgal a kapcsolat kiemelten fejlesztendő. Kínai, vietnámi, nigériai, török, iráni, szaúd-arábiai, stb. egyetemekkel lehetne például ily módon rövid időn belül intenzívebbé tenni a kapcsolatot. Az oktatók, alkalmazottak és a diákok számára a Campus Hungary által meghirdetett ösztöndíjak egy részét célzottan, országra és intézményre kellene kiírni.

A Nottinghami Egyetemhez hasonlóan a Budapesti Corvinus Egyetem Nemzetközi Oktatási Központja (ISC) 2005-ben, működésének 15. esztendejében készen állt arra, hogy campust hozzon létre Vietnámban. Az intézményi és az állami szerepvállalást, valamint az egyéb szervezetek, mint ügynökségek fontosságát jól illusztrálja az a két éves megelőző folyamat, amely 2002 novembere és 2004 decembere között lezajlott, és amelynek a fontosabb lépcsőit tartalmazza a következő leírás. ${ }^{10}$

9 A Budapesti Corvinus Egyetem így fogadott egy fél évre egy nemzetközi hírű német agrárközgazdász professzort a Kieli Egyetemről. Más logika és finanszírozás alapján, de a Harvardi Egyetem 75 éves koráig foglalkoztatta Kornai János professzort minden évben fél éves időtartamra. Most 85 évesen, tiszteletbeli emeritus professzorként a BCE foglalkoztatja. A határon túli egyetemek magyar nyelvű programjait is hatékonyan tudná segíteni egy ilyen program.

10 Sajnálatos módon a BCE vietnámi campusa nem jött létre, miként a BME kihelyezett MBA programja sem, de tanulságul szolgálhat egy újabb akcióhoz. 
14. táblázat: A vietnámi piac megdolgozásának fontosabb eseményei 2002-2004. Budapesti Corvinus Egyetem, International Studies Center (ISC)

\begin{tabular}{|c|c|}
\hline $\begin{array}{l}2002 . \\
\text { november }\end{array}$ & $\begin{array}{l}\text { Vietnam Educational Consultants Association (VIECA) Diákvásáron való részvé- } \\
\text { tel Hanoi, HCMC, } \\
\text { DIPLOMÁCIAI MEGBESZÉLÉSEK } \\
\text { Dr. Bohár Ernő nagykövet úr által szervezett Öregdiák találkozón való részvétel } \\
\text { Találkozó Dr. Váraljai Márton konzul úrral } \\
\text { A vietnámi látogatás eredménye: } 5 \text { ügynökségi szerződés megkötése }\end{array}$ \\
\hline 2003. április & Magyarországon végzett kb. 700 öregdiákkal levélben kapcsolatfelvétel \\
\hline $\begin{array}{l}2003 . \\
\text { szeptember }\end{array}$ & 15 vietnámi hallgató tanul a BCE-ISC-ben \\
\hline 2003. október & $\begin{array}{l}\text { ÜGYNÖKSÉGI TALÁLKOZÓK, DIREKT HALLGATÓTOBORZÁS } \\
\text { VIECA diákvásár, HCMC - Vietnam Centre Point } \\
\text { DIPLOMÁCIAI MEGBESZÉLÉSEK } \\
\text { Magyar Nagykövetség, Hanoi - Dr. Szász Dénes nagykövet úr } \\
\text { Magyar Főkonzulátus, HCMC - Dr. Nyerki József főkonzul úr } \\
\text { Oktatási és Továbbképzési Minisztérium - Prof. Dr. Tran Van Nhung oktatási mi- } \\
\text { niszterhelyettes és } 5 \text { munkatársa } \\
\text { EGYETEMI KAPCSOLATÉPÍTÉS } \\
\text { RMIT - HCMC Michael Mann igazgató, Nemzeti Közgazdaságtudományi Egyetem } \\
\text { meglátogatása - Prof. Dr. Nguyen Van Thuong rektor úr és } 6 \text { munkatársa }\end{array}$ \\
\hline 2004. március & $\begin{array}{l}\text { HALLGATÓTOBORZÁS, International Campus Day (Vietnam Centre Point } \\
\text { szervezésében) } \\
\text { Négy középiskola meglátogatása } \\
\text { EGYETEMI KAPCSOLATOK ÉPÍTÉSE Academy of Finance Sub-Institute } \\
\text { - HCMC, Can Tho Város Okatási Központ, Can Tho Közgazdasági Egyetem } \\
\text { Közgazdasági Kar, University of Economics - HCMC } \\
\text { MAGYARORSZÁGON VÉGZETTEKKEL VALÓ TALÁLKOZÁS } \\
\text { Vietnámi Magyar Baráti Társaság és Saigoni tagozata } \\
\text { DIPLOMÁCIAI MEGBESZÉLÉS } \\
\text { Magyar Főkonzulátus, HCMC - Dr. Nyerki József főkonzul úr }\end{array}$ \\
\hline 2004. április & $\begin{array}{l}\text { Ngo Thoi Nhiem Private High School, the Academy of Finance and the BCE-ISC } \\
\text { együttműködési szerződés aláírása Budapesten } \\
\text { Találkozás Gilyán György államtitkár úrral a vietnámi kapcsolatépítés ügyében }\end{array}$ \\
\hline 2004. május & $\begin{array}{l}\text { Oktatási együttműködési munkaterv keretében a BCE-ISC meghirdet a 2005/06 } \\
\text { tanévtől egy vietnámi fó részére egy Master ösztöndíjat }\end{array}$ \\
\hline 2004.jún & Syminisztériumi főosztályv \\
\hline
\end{tabular}


BCE rektor vezette delegáció vietnámi látogatása, együttműködési szerződé2004. október sek aláírása négy vezető egyetemmel: University of Economics (HCMC), Hue University (Hue), National University of Economics (Hanoi), Finance Academy, Ministry of Finance (Hanoi)

Forrás: Berács József (2005): ISC stratégiai terv, 2005-2020, Budapesti Corvinus Egyetem, 2005. január, kézirat, 29-30.

Az intézmények felkészítése a külföldi hallgatók fogadására az idegen, elsősorban angol nyelvű programok összeállításával kezdődik. Ezt célszerü intézményi katalógusba foglalni, amely nyomtatva és elektronikusan is elérhető. Az Erasmus és más csereprogramok céljait is szolgáló ECTS katalógusok megléte esetén ezeket kell továbbfejleszteni. A katalógus tartalmazza mindazokat az információkat, amit egy külföldi hallgatónak tudnia kell ahhoz, hogy elkezdhesse tanulmányait. Az intézmény vezetésének egyértelmű célokat kell megfogalmazni rövid és hosszú távon, hogy honnan, mennyi hallgatót szeretnének toborozni, milyen bevételi terveik vannak, és milyen költségeket vállalnak ennek érdekében. A költségterv egyben a tevékenységek felsorolását is jelenti. Harmadsorban a rendelkezésre álló és szükséges munkaerőigényt kell meghatározni, mind oktatói, kutatói, mind adminisztratív területen. Jelenleg az intézmények többsége nem tudja megmondani, hogy fóállású egyenértékben (FTE) hány fó és milyen kategóriában vesz részt az export tevékenységben.

Ami az állami szerepvállalást illeti, ugyanezt a három területet emeljük ki. El kell készíteni és aktualizálni az angol nyelvü programok országos kataszterét/katalógusát/tájékoztatóját. Egyértelmü célokat kell megfogalmazni, miként korábban javasoltuk, a külföldi hallgatók számára, országok és szakterületek szerinti megoszlására vonatkozóan. Ha a cél Kinából és Vietnámból a közgazdasági üzleti képzésre tízszer annyi hallgató vonzása, akkor el kell dönteni, hogy ezt milyen erőforrással és milyen intézményi támogatással lehet elősegíteni. A külképviseletnél ez milyen munkát generál, hol kell konzulátust nyitni vagy megtartani, hol kell a kulturális kapcsolatokban a tudományt fokozottabban előtérbe helyezni, a kormányközi bizottságok munkájában hol lehet megjeleníteni. A magyar egyetemek, városok többsége számára külön kihivást jelentenek a felmerülö kulturális különbségek. Még egy nyugat-magyarországi kisváros, mint Sopron, Győr, vagy Veszprém számára is külön felkészülést igényel az, hogy megfelelően integrálja a mindennapi életbe a más kultúrából érkező diákokat. A Bevándorlási Hivatal, a Rendőrség, az önkormányzat, a turisztikai hivatal, az orvosi rendelők, stb. csak néhány olyan szervezet, amelyek felkészítését az államnak kellene elősegíteni.

\subsection{Egy lehetséges feladatterv a fejlesztésben érintettek számára}

A tanulmány eddigi fejezeteiben, a tények bemutatása kapcsán számos gyakorlati javaslatot fogalmaztunk meg, amelyek alkalmazása növelheti az egyes intézmények és az egész magyar felsőoktatás nemzetközi versenyképességét, javíthatja nemzetközi pozícióját. Egy olyan egyszerű kijelentés, hogy el kell készíteni az angol nyelvü programok katalógusát vagy egy országismertetőt, számos részfeladatot jelent. A külföldi hallgatók számának megduplázása, mint cél megfogalmazása, ismét elég egyértelműen indít el egy egész láncreakciót a feladatokat illetően. A részfeladatokra vonatkozóan pedig további kutatásokra van szükség. A következő, összegző táblázatban négy érintett körre, a felsőoktatási intézményekre, a kormányzati szervekre, valamint a Balassi Intézetre és a Tempus Közalapítványra vonatkozóan, négy átfogó terület kapcsán fogalmazunk meg lehetséges feladatokat.

Először is szükség van a stratégiai irányok kijelölésére, konkrét számok megfogalmazására. A 
szolgáltatás tárgyát jelentő programok kidolgozása, továbbfejlesztése jelenti a feladatok második körét. Harmadszor az eröforrások, költségek hozzárendelése a programokhoz, célpiacokhoz adja meg az útmutatást minden érintett számára, hogy mennyire komolyan lehet venni az elhatározásokat. Végül a piaci sikert biztosító intézményi és közösségi marketing stratégiák elkészítése, egyes elemeinek kiemelése szerepel a feladattervben.

15. táblázat: Egy lehetséges feladatterv a külföldi hallgatók létszámának növelésére, kiemelt szereplők számára

\begin{tabular}{|c|c|c|c|c|}
\hline Feladatokirányai & $\begin{array}{l}\text { Felsőoktatási } \\
\text { intézmények }\end{array}$ & $\begin{array}{l}\text { Kormányzati } \\
\text { szervek (EMMI, } \\
\text { KM, KIM) }\end{array}$ & Balassi Intézet & $\begin{array}{l}\text { Tempus } \\
\text { Közalapítvány }\end{array}$ \\
\hline $\begin{array}{l}\text { 1. Stratégiai } \\
\text { irányok, célok, } \\
\text { országok, régiók } \\
\text { kijelölése }\end{array}$ & $\begin{array}{l}\text { Az országokat } \\
\text { lefedő márka- } \\
\text { térképek meg- } \\
\text { rajzolása, 2020- } \\
\text { ratervezett } \\
\text { meghatározása. }\end{array}$ & $\begin{array}{l}\text { Agazdasági, diplo- } \\
\text { máciai és kulturális } \\
\text { kapcsolatokban } \\
\text { a felsőoktatás- } \\
\text { nak szánt szerep } \\
\text { meghatározása. }\end{array}$ & $\begin{array}{l}\text { A külföldi magyar } \\
\text { intézetek tudatos } \\
\text { együttműkö- } \\
\text { dése a külföldi } \\
\text { felsőoktatási } \\
\text { intézményekkel. }\end{array}$ & $\begin{array}{l}\text { AzErasmus+, } \\
\text { CEEPUS és más } \\
\text { csereprogramok } \\
\text { révén a 2020-as } \\
\text { mobilitási bench- } \\
\text { mark elérése. } \\
\text { Beutazók létszámá- } \\
\text { nak növelése. }\end{array}$ \\
\hline $\begin{array}{l}\text { 2.Programfej- } \\
\text { lesztések }\end{array}$ & $\begin{array}{l}\text { Szakok, karok } \\
\text { idegen nyelvü } \\
\text { programjainak } \\
\text { fejlesztése } \\
\text { a fenti célok } \\
\text { érdekében. } \\
\text { Nemzetközi iro- } \\
\text { dák fejlesztése. }\end{array}$ & $\begin{array}{l}\text { Nemzetköziesítést } \\
\text { támogató jogsza- } \\
\text { bályi feltételek, } \\
\text { idegen nyelvű kép- } \\
\text { zések fejlesztése. }\end{array}$ & $\begin{array}{l}\text { Kulturális } \\
\text { diplomácia } \\
\text { eszköztárának } \\
\text { felhasználása az } \\
\text { országközi kap- } \\
\text { csolatok fejlesz- } \\
\text { tése érdekében. }\end{array}$ & $\begin{array}{l}\text { Az egyetemek nem- } \\
\text { zetközivé válását } \\
\text { szolgáló képzések, } \\
\text { nemzetköziesítést } \\
\text { támogató intézmé- } \\
\text { nyi szolgáltatások, } \\
\text { külföldi vásárok és } \\
\text { szakmai hálózatok. }\end{array}$ \\
\hline $\begin{array}{l}\text { 3. Eröforrások, } \\
\text { költségek } \\
\text { hozzárendelése }\end{array}$ & $\begin{array}{l}\text { AzIFT kiegészí- } \\
\text { tése a nemzet- } \\
\text { közi mobilitás } \\
\text { költség és mun- } \\
\text { kaerő igényével, } \\
\text { bevételi tervvel. }\end{array}$ & $\begin{array}{l}\text { A minisztériumok } \\
\text { és az EU 2014-2020 } \\
\text { hazai költségveté- } \\
\text { sében meghatároz- } \\
\text { ni azt a hányadot, } \\
\text { ami a felsőoktatás } \\
\text { nemzetközivé válá- } \\
\text { sát szolgálja. }\end{array}$ & $\begin{array}{l}\text { Növekvő } \\
\text { állami források } \\
\text { tervezése a } \\
\text { kulturális diplo- } \\
\text { mácia fejlesztése } \\
\text { érdekében. }\end{array}$ & $\begin{array}{l}\text { Ösztöndíjazásra és } \\
\text { nemzetközi szol- } \\
\text { gáltatásfejlesztésre } \\
\text { fordítható Európai } \\
\text { Uniós és hazai } \\
\text { források közötti } \\
\text { szinergia erősítése. }\end{array}$ \\
\hline
\end{tabular}




\begin{tabular}{|c|c|c|c|c|}
\hline $\begin{array}{l}\text { 4. Marketing, pi- } \\
\text { ackutatás, közös- } \\
\text { ségi marketing }\end{array}$ & $\begin{array}{l}\text { Stratégiai } \\
\text { partnerségek } \\
\text { kialakítása, } \\
\text { kapcsolódás } \\
\text { nemzetközi } \\
\text { szakmai } \\
\text { hálózatokhoz. }\end{array}$ & $\begin{array}{l}\text { Nemzetközi megje- } \\
\text { lenésre fordítható } \\
\text { források hosszú } \\
\text { távú tervezése, } \\
\text { regionális fókusz- } \\
\text { pontok kijelölése. } \\
\text { Európai felsőok- } \\
\text { tatási térségbe } \\
\text { való beágyazódás } \\
\text { elősegítése. }\end{array}$ & $\begin{array}{l}\text { Hazai és nemzet- } \\
\text { közi kulturális } \\
\text { események, } \\
\text { országpromóció a } \\
\text { magyar felsőok- } \\
\text { tatás népszerűsí- } \\
\text { tése érdekében. }\end{array}$ & $\begin{array}{l}\text { Mobilitási tren- } \\
\text { dek és tendenciák } \\
\text { nyomon követése, } \\
\text { elemzése, célzott } \\
\text { és rendszeres } \\
\text { nemzetközi megje- } \\
\text { lenések koordiná- } \\
\text { lása felsőoktatási } \\
\text { vásárokon. }\end{array}$ \\
\hline
\end{tabular}

\section{Felhasznált irodalom}

A kormány 1668/2012. (XII. 21.) Korm. határozata a magyar felsőoktatás megújításáról, Magyar Közlöny 2012. évi 176. szám, 29760.

Balázs S. - Bodó B. - Csetri E. - Gaál Gy. - Kónya-Hamar S. -Somai J. (2009): Fehér könyv az erdélyi magyar felsőoktatás kálváriájáról, Bolyai Egyetem Barátainak Egyesülete, Kolozsvár

Bander Katalin (2011): Vállalt küldetések az intézményi honlapok alapján, in: Hrubos (szerk.): Mühelytanulmányok, NFKK Füzetek 8, 58-88.

Barakonyi Károly (2010): A felsőoktatás versenyképességéről, Vezetéstudomány, 41(12), 4-19.

Berács József (2002): Piacorientáció: közgazdasági és marketing megközelítés, Kézirat, MTA doktori értekezés, Budapest

Berács József (2008): Tudásexport a felsőoktatásban: egy hierarchikus megközelítés, Competitio, 7(2), $35-48$.

Berács József (2011): „Knowledge Export in Higher Education: A hierarchic approach, Economic Review/Ekonomické Rozhlady, Vol. 40, No. 2,147-162.

Berács J. - Hrubos I. - Temesi J. (szerk. 2011): „Magyar Felsőoktatás 2010” Konferencia előadások, NFKK Füzetek 6, 2011. március

Berács J.- Hubert J.- Nagy G. (2009): A magyar felsőoktatás nemzetköziesedésének folyamata 1, Bologna Füzetek 3, TKA, Budapest

Berács J. - Malota E.- Zsótér (2011): A magyar felsőoktatás nemzetköziesedésének folyamata 2, Bologna Füzetek 8, TKA, Budapest

Berács József - Malota Erzsébet (2011): Megéri hozzánk jönni tanulni?, Educatio, 20. évf., 2. szám, 220-234.

Bhandari, Rajika (2009): Trends in Student Global Mobility: Perspectives from Open Doors \& Project Atlas, Presentation in IIE, May 6, 2009, Washington D. C.

Bhandari, Rajika - Laughlin, Sheperd (2009): Higher Education on the Move: New Developments of Global Mobility, Institute of International Education, New York

Chikán Attila (2011) szerk.: A multinacionális vállalatok szerepe a hazai KKV-ék versenyképességének a növelésében, BCE Versenyképességkutató Központ

Cadogan, J.W. - Diamatopoulos, A. - Mortanges, Ch. P. (2009): Export Market-Oriented Behavior 
and Export Performance: Quadratic and Moderating Effects Under Differing Degrees of Market Dynamism and Internationalization, Journal of International Marketing, 17(4), 71-89.

Davis, Todd, M. (2003): Atlas of Student Mobility, Institute of International Education, New York

Ennew, Christine T. - Fujia, Yang (2009): Foreign Universities in China: a case study, European Journal of Education, 44(1), 21-36.

Hrubos Ildikó (2011): Intézményi sokféleség a felsőoktatásban, in: Hrubos, Ildikó (Szerk.) NFKK Füzetek 8., Mühelytanulmányok, 9-30.

Hrubos Ildikó (2012) szerk.: Elefántcsonttoronyból világítótorony - A felsőoktatási intézmények misszióinak bövülése, átalakulása, Aula Kiadó, Budapest

Jobbágy Ákos (2009): Tömegképzés és elitképzés a magyar felsőoktatásban, in: : Berács-Hrubos-Temesi (2009): „Magyar Felsőoktatás 2008” Konferencia Előadások, BCE-NFKK Füzetek 1., 88-112. Budapest

Kirca, A.H. - Jayachandran, S. - Bearden, W.O. (2005): Market Orientation: A Metaanalytic Review and Assessment of its Antecedents and Impact on Performance, Journal of Marketing, Vol. 69, April, 24-41.

Kornai János (2011): Gondolatok a kapitalizmusról, Akadémiai Kiadó, Budapest

L. Rédei Mária (2009): A tanulmányi célú mozgás, REG-INFO Kft, Budapest

Mazzarol, T. S. - Normann, G. (2001): The Global Market for Higher Education, Sustainable competitive strategies for the new millenium, Edward Elgar, Chettenham, U.K.

Marga, Andrei (2010): Quality and Excellence, The strategy for excellence of Babes-Bolyai University, in: Berács-Hrubos-Temesi (2010), 73-88.

Nagy-Palánkai-Miklós-Endrődi-Baranyi (2011): Internationalisation (Transnationalisation) of the Enterprise Sector. Working Paper, Corvinus University of Budapest

Nagy Gábor - Berács József (2011): A felsőoktatás mint export:A magyar felsőoktatási intézmények export piaci orientációjának előzményei és teljesítményre kifejtett hatása, in: Hrubos I. (2011) (Szerk.): NFKK Füzetek 8., Mühelytanulmányok, BCE-NFKK, Budapest, 141-160.

OECD Statistics, Tertiary Education (ISCED 5 and 6) International Flows of mobile students,2009, www.uis.unesco.org/Education/Documents/Ooutbound\%20Mobility_EN_static_20110817.xls

OECD (2012): Education at a Glance 2012: OECD Indicators, OECD Publishing. http://dx.doi. org/10.1787/eag-2012-en

Opendoors 2006, Report on international educational exchange, Institute of International Education, USA

Polónyi István (2009): A magyar felsőoktatás finanszírozása a korai 2000-es években, in: BerácsHrubos-Temesi (2009): „Magyar Felsőoktatás 2008” Konferencia Előadások, BCE-NFKK Füzetek 1., 88-112. Budapest

Porter, Michael (1998): The Competitive Advantage of Nations, New edition with updates in an Introduction by the author, MacMillan Business

Project Atlas: Trends and Global Data 2011, Institute of International Education,

Sadlac, J. - Liu Nian Caj (eds.)(2007): The World-Class University and Ranking:Aiming Beyond Status. Cluj University Press

Statisztikai Tájékoztató, Oktatási Évkönyv 2011/2012, Emberi Erőforrások Minisztériuma, Budapest, 2012

Teichler, U. - Ferencz, I. - Waechter, B. (Eds.)(2011): Mapping Mobility in European higher education, Volume I: Overview and trends, A study produced for the Directorate General for Education and Culture (DG EAC), of the European Commission, Brussels, June 2011

Temesi József (2012) szerk.: Felsőoktatás-finanszírozás: Nemzetközi tendenciák és a hazai helyzet, Aula Kiadó, Budapest 
Temesi József - Hrubos Ildikó - Berács József (2013): Magyar Felsőoktatás 2012 - Stratégiai helyzetértékelés, BCE - Nemzetközi Felsőoktatási Kutatások Központja, Budapest, Kézirat, 17.

Török Ádám (2006): Az európai felsőoktatás versenyképessége és a lisszaboni célkitűzések. Mennyire hihetünk a nemzetközi egyetemi rangsoroknak? Közgazdasági Szemle, 53(4), 310-329

Török Ádám - Kovács Bernadett (2011): A nemzetközi felsőoktatási verseny mérési problémáiról, in: Berács-Hrubos-Temesi (szerk.), 9-23.

Transition Report 2010, Recovery and Reform, European Bank for Reconstruction and Development Transition Report 2012, Integration across borders, European Bank for Reconstruction and Development Schmidt, Helmut (2004): Die Maechte der Zukunft, Gewinner und Verlierer in der Welt von morgen, Siedler Verlag, München

U-Multirank: a multi-dimensional global university ranking, www.u-multirank.eu

Van Galen, Adinda (Ed. 2010): Internationalisation and Quality Assurance, EAIE Professional Development Series for International Educators 4, EAIE, Amsterdam 


\section{Mobilitást akadályozó és ösztönző intézményi tényezők}

Szakértői interjúk és dokumentumok elemzése

\section{Készítette:}

Berács József, egyetemi tanár, kutatásvezető

ISC Alapítvány

A kutatás a TÁMOP-4.2.4.B/2-11/1-2012-0001 projekt keretében valósult meg.

2013. augusztus 31 . 


\title{
1. A mobilitást ösztönző és akadályozó intézményi tényezők koncepcionális megközelítése, a kutatás tervezése
}

A Campus Hungary program keretében a Tempus Közalapítvány által a „Mobilitást ösztönző és akadályozó tényezők Magyarországon” címmel meghirdetett kutatási tendert az ISC Alapítvány nyerte el. A kutatás két nagy feladatcsoportra összpontosított.

Az 1. feladat (TÁMOP 4.2.4.B/1-11/1 projekt) két tanulmányt foglal magában:

a. Helyzetfeltáró tanulmány készítése a meglévő és a szükséges kreditelismerési egyezményekről, az ECTS és más hasonló kreditrendszerek működéséről, a szükséges fejlesztésekről

b. Tanulmány az idegenrendészeti és mobilitás szervezési ügyek felsőoktatási intézmények számára adódó kapcsolatáról
A 2. feladat (TÁMOP 4.2.4.B/2-11/1 projekt) négy tanulmányt foglal magában. Ezek:
a. Mobilitást akadályozó és ösztönző intézményi tényezők (jelen tanulmány)
b. Hallgatói attitüdök, interkulturális készségeik, felkészültségük a külföldi tanulmányokra (belföldi hallgatók)
c. Külföldi hallgatók közötti igény és véleményfelmérés
d. Felmérés a hallgatók „nemzetköziesítését” célzó kurzusokról

\begin{abstract}
A kutatások megtervezésénél, valamint a konkrét feladatok meghatározásánál kiemelt cél volt, hogy támaszkodjunk a Balassi Intézet és a Tempus Közalapítvány által korábban készített kutatásokra. Ez részben az érintett tanulmányok (részletes felsorolásukat lásd a felhasznált irodalom címszó alatt) előzetes olvasását jelentette. Másrészt a Megbízó, a Tempus Közalapítvány munkatársaival való folyamatos konzultációt a vizsgálat tárgyának a meghatározásában, a kutatási kérdőívek, interjú vezérfonalak kidolgozásában. A 2. feladat elvégzése elsősorban megkérdezésekre, mélyinterjúkra támaszkodik, különböző célcsoportokat választva ki, ugyanazokra a témakörökre vonatkozóan.

A tágan értelmezett mobilitást a nemzetközivé válás fontos indikátoraként fogjuk fel ${ }^{1}$. Az intézményi cserekapcsolatokon túl beleértünk minden tanulmányi, kutatási, oktatási, tapasztalatszerzési célból megvalósuló külföldi utat, migrációt, legyen szó beutazásról vagy kiutazásról. Egy más megközelítésben a nemzetközi kitettség mérése kapcsán (Berács 2012) a mobilitáshoz tapadó emberi erőforrások időigénye, illetve az azt kísérő pénzmozgások, éves nemzetközi költések teljes költségvetéshez viszonyított arányával is lehet jellemezni az intézmény külkapcsolatainak nagyságát. Ebből a szempontból is tanulságos az Erasmus támogatások felosztása különböző részterületekre, mobilitási alanyokra és adminisztrációra (1. táblázat). A 2013/14-es tanévben csökkenő, de 10 és fél millió eurót meghaladó keretből tízszer annyi kerül tanulmányi célú hallgatói, mint oktatói mobilitásra. A legnagyobb tételt jelentő hallgatói mobilitáson belül növekvő arányt jelent a szakmai gyakorlati célú kiutazás a tanulmányi célú kiutazással szemben.
\end{abstract}

\footnotetext{
1 Jelen tanulmányban nem kívánunk elméleti fejtegetésekbe bocsátkozni a nemzetköziesítés és a mobilitás fogalmait illetően. A Balassi Intézet 2013. március 21-én tartott konzultációján a „Mobilitási adattár és elemző központ” című kutatásban javasolt fogalmi meghatározás - véleményünk szerint - szűken határozza meg mindkét fogalmat. „Felsőoktatás nemzetköziesítése: a felsőoktatási intézmények ágazati és intézményi szintű nemzetközi kapcsolatainak, kapcsolódásainak összessége, amelynek egy része lehet mobilitási kapcsolat. Mobilitás: hallgatói, oktatói, munkatársi cserekapcsolat felsőoktatási intézmények között.”
} 
1. táblázat: A 2012-ben és 2013-ban megitélt Erasmus támogatások összege és a 2011/12-es esztendö tényei

\begin{tabular}{|l|l|l|l|}
\hline Tanév & 2011/2012 & 2012/2013 & 2013/2014 \\
\hline Hallgatói mobilitás & 6968942 & 7440267 & 7000000 \\
\hline Szakmai gyakorlat & 1245334 & 1776440 & 1681250 \\
\hline Oktatói mobilitás & 644018 & 699998 & 700000 \\
\hline Személyzeti mobilitás & 308439 & 400001 & 400030 \\
\hline & & 797340 & 772750 \\
\hline Mobilitás szervezés & 660391 & 11114046 & 10554030 \\
\hline Összesen megítélt (EUR) & 9827124 & & \\
\hline
\end{tabular}

Forrás: TKA adatközlés

\subsection{Központi és konvergencia régiók összehasonlítása}

A kevésbé fejlett európai országok felzárkózása a fejlett országokhoz csak úgy valósulhat meg, ha a vizsgált országok különböző régiói nem a leszakadás, hanem az erőteljesebb fejlődés jeleit mutatják. Magyarország gazdasági fejlettség szempontjából legelmaradottabb régiója Észak-Magyarország, a legújabb Eurostat jelentések szerint az EU 8. legszegényebb régiója az egy före jutó GDP alapján. Anélkül, hogy részletes elemzésbe bocsátkoznánk, meglepő, hogy az Erasmus támogatás befogadási képessége a szegényebb régiókban alacsonyabb, mint amit a GDP termelés alapján várhatnánk (2. táblázat). A szakmai gyakorlati célú mobilitásban különösen nagy az elmaradás az Észak-Magyarország régióban.

2. táblázat: Gazdasági teljesitmény az érintett régiókban (2009) és a 2013/2014-es Erasmus támogatás egyes elemei

\begin{tabular}{|l|l|l|l|l|l|l|}
\hline Terület & $\begin{array}{l}\text { Lakosság } \\
\text { fö }\end{array}$ & $\begin{array}{l}\text { GDP } \\
\text { (milli- } \\
\text { árd Ft) }\end{array}$ & $\begin{array}{l}\text { Egy före } \\
\text { jutó GDP } \\
\text { (1000 Ft) }\end{array}$ & $\begin{array}{l}\text { Összes } \\
\text { Erasmus } \\
\text { támogatás } \\
\text { (euró) }\end{array}$ & $\begin{array}{l}\text { Tanulmányi } \\
\text { célú hallga- } \\
\text { tói mobilitás } \\
\text { (euró) }\end{array}$ & $\begin{array}{l}\text { Szakmai } \\
\text { gyakorlat } \\
\text { mobilitás } \\
\text { (euró) }\end{array}$ \\
\hline $\begin{array}{l}\text { Közép-Magyar- } \\
\text { ország }\end{array}$ & 2938396 & 12608,7 & 4291 & 6248600 & 4302580 & 1024900 \\
\hline $\begin{array}{l}\text { Közép-Dunán- } \\
\text { túl }\end{array}$ & 1100910 & 2340,0 & 2126 & 702500 & 407380 & 152950 \\
\hline $\begin{array}{l}\text { Nyugat-Du- } \\
\text { nántúl }\end{array}$ & 997169 & 2377,2 & 2384 & 500140 & 323090 & 80400 \\
\hline
\end{tabular}




\begin{tabular}{|l|l|l|l|l|l|l|}
\hline Dél-Dunántúl & 950579 & 1674,9 & 1762 & 814180 & 519460 & 133700 \\
\hline $\begin{array}{l}\text { Észak- } \\
\text { Magyarország }\end{array}$ & 1216471 & 1900,1 & 1562 & 496410 & 326120 & 43850 \\
\hline Észak-Alföld & 1497408 & 2484,2 & 1659 & 839170 & 511910 & 147700 \\
\hline Dél-Alföld & 1322207 & 2237,2 & 1692 & 953030 & 609460 & 97750 \\
\hline \multicolumn{1}{|c|}{ Együtt: } & 10023140 & 25622,9 & 2556 & 10554030 & 7000000 & 1681250 \\
\hline
\end{tabular}

Forrás: Intézményfejlesztési Tervek, femip.hu, Tabl_01 és EMMI, TKA adatközlés

Az egyes régiók nem lakosság, illetve GDP arányosan részesednek a hallgatók számából, a felsőoktatásra fordított erőforrásokból. A regionális elkötelezettségről és a Közép-Magyarország képzési régió jellemzőiről, Veroszta (2012) számol be részletesen. Jelen kutatásban az egyes régiókban található felsőoktatási intézmények állnak a vizsgálat fókuszában. A Közép-Magyarország régióból négy, míg minden konvergencia régióból két-két intézményt választottunk ki, így mindösszesen 16 intézmény jelenti a kutatás terepét.

Mobilitás szempontjából a kiutazó Erasmus hallgatók száma, valamint az adott évi hallgatói létszámhoz viszonyított aránya (3. táblázat) szemléletesen mutatja az erőviszonyokat, illetve azt, hogy a mobilitásnak milyen szerepe van az egyes intézmények stratégiájában. Már most leszögezhetjük azt az általános meglátásunkat, hogy nem elsősorban a régió maga, hanem a régióban található felsőoktatási intézmények kategóriája, típusa (nagysága, stratégiája, stb.) a meghatározó a mobilitás szempontjából. Általában igaz, hogy a nagy egyetemek élen járnak a mobilitásban, de mindig vannak kivételek. Például a Debreceni Egyetemen országos átlag alatti az Erasmus hallgatók aránya az adott évi hallgatói létszámhoz képest (0,7\%), miközben vezető szerepet töltenek be sok más területen a nemzetközivé válásban (Berács:2012).

3. táblázat: Az Erasmus hallgatók aránya a hallgatók létszámához képest a kiválasztott 16 intézményben, 2009-2011

\begin{tabular}{|l|l|l|l|l|l|l|}
\hline & $\begin{array}{l}\text { Kiutazó } \\
\text { Erasmus } \\
\text { hallgatók } \\
\mathbf{2 0 0 9 / 1 0}\end{array}$ & $\begin{array}{l}\text { Erasmus } \\
\text { hallgatók } \\
\text { aránya az } \\
\text { adott évi } \\
\text { hallgatói } \\
\text { létszám- } \\
\text { hoz képest }\end{array}$ & $\begin{array}{l}\text { Kiutazó } \\
\text { Erasmus } \\
\text { hall- } \\
\text { gatók } \\
\mathbf{2 0 1 0 / 1 1}\end{array}$ & $\begin{array}{l}\text { Erasmus } \\
\text { hallgatók } \\
\text { aránya az } \\
\text { adott évi } \\
\text { hallgatói } \\
\text { létszám- } \\
\text { hoz képest }\end{array}$ & $\begin{array}{l}\text { Kriutazó } \\
\text { Erasmus } \\
\text { hallgatók } \\
\mathbf{2 0 1 1 / 1 2}\end{array}$ & $\begin{array}{l}\text { Erasmus } \\
\text { hallgatók } \\
\text { aránya az } \\
\text { adott évi } \\
\text { hallgatói } \\
\text { létszámhoz } \\
\text { képest }\end{array}$ \\
\hline $\begin{array}{l}\text { Budapesti Múszaki } \\
\text { és Gazdaságtudo- } \\
\text { mányi Egyetem }\end{array}$ & 255 & $1,18 \%$ & 310 & $1,44 \%$ & 330 & $1,51 \%$ \\
\hline Debreceni Egyetem & 308 & $1,02 \%$ & 227 & $0,74 \%$ & 226 & $0,70 \%$ \\
\hline
\end{tabular}




\begin{tabular}{|c|c|c|c|c|c|c|}
\hline $\begin{array}{l}\text { Dunaújvárosi } \\
\text { Főiskola }\end{array}$ & 13 & $0,28 \%$ & 18 & $0,42 \%$ & 15 & $0,40 \%$ \\
\hline $\begin{array}{l}\text { Eötvös Loránd } \\
\text { Tudományegyetem }\end{array}$ & 516 & $1,70 \%$ & 510 & $1,66 \%$ & 518 & $1,74 \%$ \\
\hline $\begin{array}{l}\text { Eszterházy Károly } \\
\text { Főiskola }\end{array}$ & 33 & $0,39 \%$ & 39 & $0,47 \%$ & 50 & $0,59 \%$ \\
\hline Kaposvári Egyetem & 14 & $0,40 \%$ & 21 & $0,65 \%$ & 23 & $0,76 \%$ \\
\hline $\begin{array}{l}\text { Kecskeméti } \\
\text { Főiskola }\end{array}$ & 29 & $0,60 \%$ & 22 & $0,45 \%$ & 23 & $0,49 \%$ \\
\hline $\begin{array}{l}\text { Kodolányi János } \\
\text { Főiskola }\end{array}$ & 102 & $1,74 \%$ & 123 & $2,09 \%$ & 129 & $2,47 \%$ \\
\hline $\begin{array}{l}\text { Közép-európai } \\
\text { Egyetem }\end{array}$ & 10 & $2,82 \%$ & 10 & $2,44 \%$ & 13 & $5,35 \%$ \\
\hline Miskolci Egyetem & 106 & $0,78 \%$ & 99 & $0,71 \%$ & 88 & $0,67 \%$ \\
\hline $\begin{array}{l}\text { Nyíregyházi } \\
\text { Főiskola }\end{array}$ & 49 & $0,49 \%$ & 46 & $0,52 \%$ & 43 & $0,59 \%$ \\
\hline $\begin{array}{l}\text { Nyugat-magyaror- } \\
\text { szági Egyetem }\end{array}$ & 122 & $0,79 \%$ & 146 & $1,03 \%$ & 144 & $1,09 \%$ \\
\hline $\begin{array}{l}\text { Pázmány Péter } \\
\text { Katolikus Egyetem }\end{array}$ & 158 & $1,67 \%$ & 171 & $1,91 \%$ & 171 & $2,11 \%$ \\
\hline $\begin{array}{l}\text { Pécsi } \\
\text { Tudományegyetem }\end{array}$ & 377 & $1,23 \%$ & 376 & $1,30 \%$ & 318 & $1,19 \%$ \\
\hline $\begin{array}{l}\text { Széchenyi István } \\
\text { Egyetem }\end{array}$ & 61 & $0,62 \%$ & 61 & $0,62 \%$ & 56 & $0,53 \%$ \\
\hline $\begin{array}{l}\text { Szegedi } \\
\text { Tudományegyetem }\end{array}$ & 343 & $1,22 \%$ & 307 & $1,14 \%$ & 369 & $1,39 \%$ \\
\hline
\end{tabular}

\section{Forrás: TKA adatközlés}

A Magyarországon bejegyzett felsőoktatási intézmények fő típusainak meghatározását Hrubos-Horváth (2012) végezte el az európai felsőoktatási intézmények klasszifikációs projektje, az ún. U-Map módszertani útmutatásai alapján. Eredményként, a sokféleség átláthatóbbá vált és a vizsgált 69 intézményt 
nyolc típusba, csoportba, klaszterbe sorolták. A kutatásunkban szereplő 16 intézmény négy klaszterben található (4. táblázat). Teljesen lefedtük a legnagyobb létszámú ún. „klasszikus egyetemek” klasztert. Témánk szempontjából érdekes „nemzetközi egyetem” klaszter két magánintézményt foglal magába, amelyek mind Budapesten találhatók, és közülük a CEU került be a mintánkba. A hat konvergencia régióból háromban található nagy, univerzális egyetem, amely emiatt meghatározza a régió profilját is.

4. táblázat: A vizsgált intézmények elhelyezkedése a U-Map klaszterekben

\begin{tabular}{|c|c|c|c|c|c|c|c|}
\hline $\begin{array}{l}\text { Klaszterek } \\
\text { megneve- } \\
\text { zése (in- } \\
\text { tézmények } \\
\text { száma) }\end{array}$ & $\begin{array}{l}\text { Dél- } \\
\text { Dunánúl }\end{array}$ & $\begin{array}{l}\text { Közép- } \\
\text { Dunántúl }\end{array}$ & $\begin{array}{l}\text { Nyugat- } \\
\text { Dunántúl }\end{array}$ & $\begin{array}{l}\text { Dél- } \\
\text { Alföld }\end{array}$ & $\begin{array}{l}\text { Észak- } \\
\text { Alföld }\end{array}$ & $\begin{array}{l}\text { Észak- } \\
\text { Magyar- } \\
\text { ország }\end{array}$ & $\begin{array}{l}\text { Közép- } \\
\text { Magyar } \\
\text { ország }\end{array}$ \\
\hline $\begin{array}{l}\text { 3. Klaszter } \\
\text { Nagyobb } \\
\text { hallgatói } \\
\text { létszámú, } \\
\text { szélesebb } \\
\text { képzési } \\
\text { profilú főis- } \\
\text { kolák (10) }\end{array}$ & & $\begin{array}{l}\text { Duna- } \\
\text { újvárosi } \\
\text { Főiskola, } \\
\text { Kodolá- } \\
\text { nyi János } \\
\text { Főiskola }\end{array}$ & & $\begin{array}{l}\text { Kecs- } \\
\text { keméti } \\
\text { Főiskola }\end{array}$ & $\begin{array}{l}\text { Nyír- } \\
\text { egyházi } \\
\text { Főiskola }\end{array}$ & $\begin{array}{l}\text { Eszterhá- } \\
\text { zy Károly } \\
\text { Főiskola }\end{array}$ & \\
\hline $\begin{array}{l}\text { 5. Klaszter } \\
\text { Széles } \\
\text { profilú, de a } \\
\text { klasszikus- } \\
\text { tól eltérő } \\
\text { összetételü } \\
\text { egyetemek } \\
(12)\end{array}$ & $\begin{array}{l}\text { Kapos- } \\
\text { vári } \\
\text { Egyetem }\end{array}$ & & $\begin{array}{l}\text { Nyugat- } \\
\text {-Magyar- } \\
\text { országi } \\
\text { Egyetem, } \\
\text { Széchenyi } \\
\text { István } \\
\text { Egyetem }\end{array}$ & & & $\begin{array}{l}\text { Miskolci } \\
\text { Egyetem }\end{array}$ & $\begin{array}{l}\text { BME } \\
\text { PPKE }\end{array}$ \\
\hline $\begin{array}{l}\text { 7. Klaszter } \\
\text { Klasszikus } \\
\text { egyetemek } \\
\text { (4) }\end{array}$ & $\begin{array}{l}\text { Pécsi Tu- } \\
\text { domány- } \\
\text { egyetem }\end{array}$ & & & $\begin{array}{l}\text { Szegedi } \\
\text { Tudo- } \\
\text { mányegye- } \\
\text { tem }\end{array}$ & $\begin{array}{l}\text { Debreceni } \\
\text { Egyetem }\end{array}$ & & ELTE \\
\hline $\begin{array}{l}\text { 8. Klaszter } \\
\text { Nemzetközi } \\
\text { egyetemek } \\
\text { (2) }\end{array}$ & & & & & & & CEU \\
\hline
\end{tabular}

A U-Map típusba sorolás mögött sok-sok indikátor van, amelyek továbbiakkal bővíthetők (pl. a nemzetközivé válás szempontjából) az intézményi esettanulmányok alapján is. Máshol bővebben kifejtettük ennek irányait (Berács 2012), most csak egy területre mutatunk rá a mobilitás szempontjából. Az 5. táb- 
lázatban összegyüjtöttük a vizsgált intézmények 2011/2012-es tanévre vonatkozó összes hallgatói létszáma mellett a külföldi diplomakredites hallgatók és az Erasmus be- és kiutazó hallgatók számát. A számok önmagukért beszélnek, és segítséget nyújtanak az olvasónak az intézmények megkülönböztetésében.

A külföldi hallgatók száma, illetve az összes hallgatón belüli aránya általában szoros kapcsolatban van az Erasmus mobilitásban érintett hallgatók számával és arányával, de mindig vannak kivételek, mint pl. az említett Debreceni Egyetem, amely vezeti a külföldi hallgatók száma alapján képzett országos rangsort, míg a beutazó Erasmus hallgatók száma alapján nincs az első öt egyetemben. Az országosan megfigyelt trend, miszerint a beutazó Erasmus hallgatók száma kb. 30\%-kal, de csökkenő mértékben, elmarad a kiutazó hallgatók száma mögött, két intézmény esetében nem teljesül. A Dunaújvárosi Főiskola mellett a Közép-európai Egyetem az, ahol a kiutazók száma elmarad a beutazók száma mögött. A U-Map szerint egy klaszterbe kerülő Kaposvári Egyetem alacsony, de kiegyensúlyozott mérleget mutat (21 beutazó mellett 23 kiutazó), míg a Nyugat-Magyarországi Egyetemen a legnagyobb az „import olló”, mivel 29 beutazó Erasmus hallgatóra 144 kiutazó hallgató jut.

5. táblázat: Az összes hallgató, a külföldi hallgató, illetve a be-és kiutazó Erasmus hallgatók létszáma a kiválasztott 16 intézményben, 2011-2012

\begin{tabular}{|c|c|c|c|c|}
\hline Intézmény & $\begin{array}{l}\text { Összes hallgató } \\
\text { száma } \\
2011 / 2012\end{array}$ & $\begin{array}{l}\text { Külföldi hall- } \\
\text { gatók száma } \\
\text { 2011/2012 }\end{array}$ & \begin{tabular}{|l} 
Beutazó \\
Erasmus \\
hallgatók \\
száma \\
$2011 / 12$
\end{tabular} & $\begin{array}{l}\text { Kiutazó } \\
\text { Erasmus } \\
\text { hallgatók } \\
\text { száma } \\
2011 / 12\end{array}$ \\
\hline $\begin{array}{l}\text { Budapesti Műszaki és } \\
\text { Gazdaságtudományi } \\
\text { Egyetem }\end{array}$ & 24000 & 964 & 276 & 330 \\
\hline Debreceni Egyetem & 32359 & 3336 & 173 & 226 \\
\hline Dunaújvárosi Főiskola & 3755 & 61 & 28 & 15 \\
\hline $\begin{array}{l}\text { Eötvös Loránd } \\
\text { Tudományegyetem }\end{array}$ & 29850 & 1134 & 429 & 518 \\
\hline $\begin{array}{l}\text { Eszterházy Károly } \\
\text { Főiskola }\end{array}$ & 8476 & 111 & 34 & 50 \\
\hline Kaposvári Egyetem & 3026 & 35 & 21 & 23 \\
\hline Kecskeméti Főiskola & 4700 & 68 & 15 & 23 \\
\hline $\begin{array}{l}\text { Kodolányi János } \\
\text { Főiskola }\end{array}$ & 6000 & 236 & 104 & 129 \\
\hline
\end{tabular}




\begin{tabular}{|c|c|c|c|c|}
\hline $\begin{array}{l}\text { Közép-európai } \\
\text { Egyetem }\end{array}$ & 243 & 176 & 37 & 13 \\
\hline Miskolci Egyetem & 13207 & 180 & 50 & 88 \\
\hline Nyíregyházi Főiskola & 7300 & 241 & 18 & 43 \\
\hline $\begin{array}{l}\text { Nyugat-magyarországi } \\
\text { Egyetem }\end{array}$ & 13246 & 307 & 29 & 144 \\
\hline $\begin{array}{l}\text { Pázmány Péter } \\
\text { Katolikus Egyetem }\end{array}$ & 8094 & 359 & 95 & 171 \\
\hline $\begin{array}{l}\text { Pécsi } \\
\text { Tudományegyetem }\end{array}$ & 26699 & 1764 & 210 & 318 \\
\hline $\begin{array}{l}\text { Széchenyi István } \\
\text { Egyetem }\end{array}$ & 11371 & 442 & 38 & 56 \\
\hline $\begin{array}{l}\text { Szegedi } \\
\text { Tudományegyetem }\end{array}$ & 27046 & 2282 & 210 & 369 \\
\hline
\end{tabular}

Forrás: TKA adatközlés, EMMI

Az Erasmus mobilitásban a 2011/2012-es tanévben 4361 kiutazó hallgató vett részt, akik közül 3472 fő tanulmányi célból és 889 fő szakmai gyakorlat céljából utazott külföldre. A képzési szintek szerinti megoszlást tekintve, felsőfokú szakirányú képzésben senki sem ment külföldre (2009-ben még 129 fö), alapképzésben, első ciklusban 2464 fo, második ciklusban 1803 fo, míg a harmadik, PhD ciklusban 94 fö. Az oktatói mobilitásban 1070 fö, a dolgozói mobilitásban 395 fö vett részt. Ez utóbbiak döntően egy hetes vagy még rövidebb programok, és emiatt a munkaidőalapot tekintve csak ezrelékekben fejezhetők ki.

Az Erasmus kiutazó hallgatók számát a külföldi diplomakredites hallgatók száma és az összes hallgató száma alapján képzett koordinátarendszerben ábrázolva szemléletes vizuális képet kapunk az egyes intézmények nagyságáról. A marketingben márkatérképnek, vagy pozícionálási térképnek is nevezett ábrán a buborék nagysága, területe a kiutazó Erasmus hallgatók számával arányos. Jól látható, hogy a négy klasszikus egyetem kiemelkedik a listából, akikhez felzárkózott a Budapesti Műszaki Egyetem. Az ábra legalsó tartományában szereplő két intézmény, a Kaposvári Egyetem és a Közép-európai Egyetem egészen más okok miatt került közel egymáshoz. A CEU nemzetközi egyetemként, ahol a hallgatók nagy része külföldi és döntően mesterképzésben vesz részt, nem érdekelt a kiutaztatásban, de az arány (5,35\%) még így is itt a legmagasabb. Ezzel szemben a Kaposvári Egyetem a nemzetközi orientáció alacsony szintje miatt $(0,76 \%)$ került ebbe a pozícióba. 
1. ábra: A vizsgált intézmények kiutazó Erasmus hallgatóinak a száma (buborék nagysága) az összes és a külföldi hallgatók számának függvényében

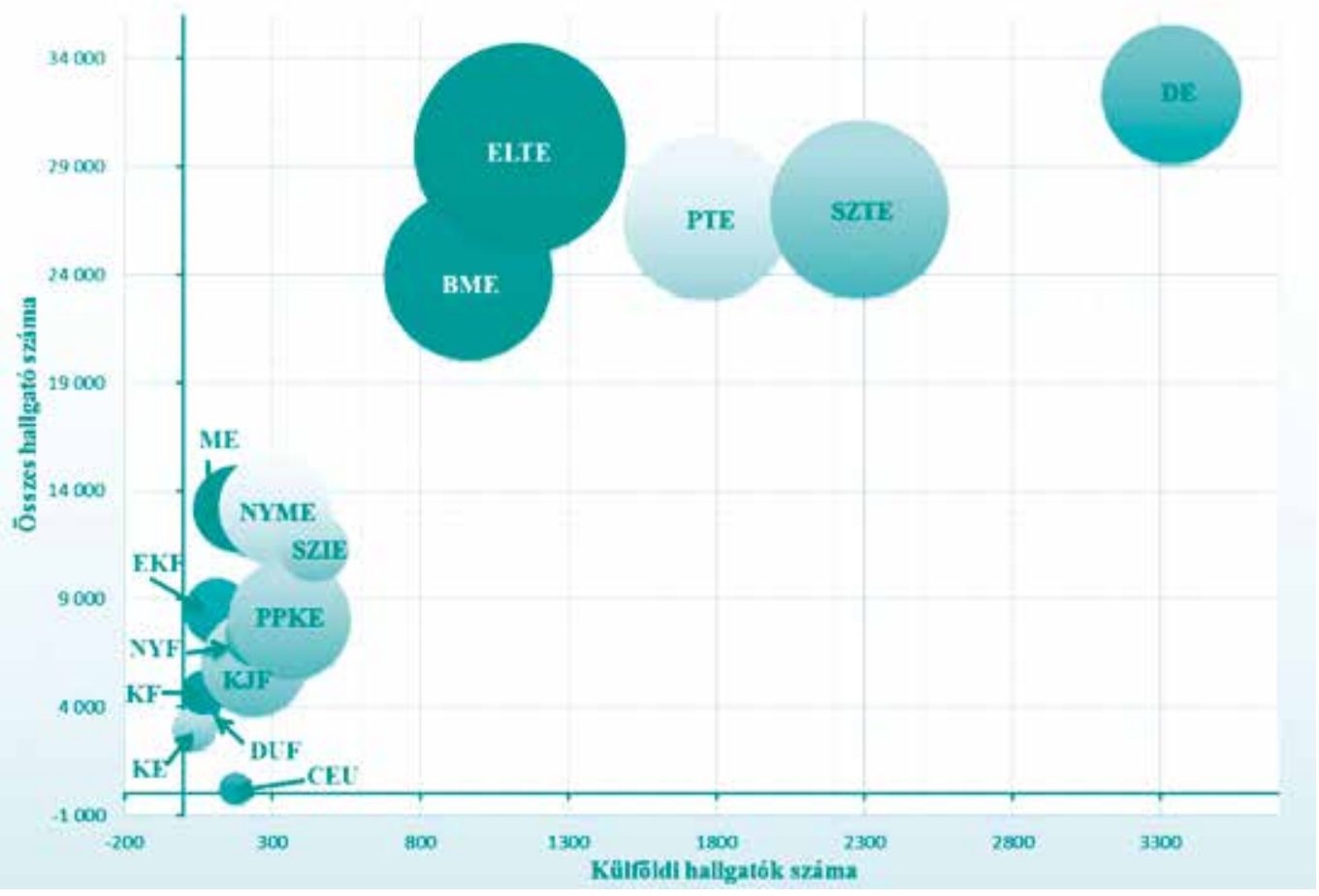

Forrás: EMMI és TKA adatközlés

Ha a beutazó hallgatók száma alapján képezzük az intézmények pozícionálási térképét (2. ábra), akkor látunk hangsúlybeli eltéréseket, de az alapvető pozíciók nem változnak. Az alapvető pozíciókat pedig a méretek határozzák meg. Egy pontosítást kell tenni az ábrához. A Közép-európai Egyetemnél 243 hallgató szerepelt a központi statisztikákban, holott valójában 1500 hallgatója van. (Lásd később az intézményi alfejezetnél.) Ezzel persze még mindig a legkisebb intézmény az „összes hallgató száma” alapján, ha azonban a tényleges 1200 külföldi hallgatóját nézzük, akkor viszont már csak a három nagy univerzitás (DE, SZTE, PTE) előzi meg. Ez a tény rávilágít egy általános problémára, miszerint a magyar hivatalos (EMMI) statisztikákból hiányoznak a külföldön bejegyzett, akkreditált intézmények Magyarországi telephelyén tanuló külföldi hallgatói. Erre is visszavezethető, hogy a Bevándorlási Hivatal több tanulmányi célú vízumkiadásról tud, számol be, mint ami a hivatalos felsőoktatási statisztikákban megjelenik². 
2. ábra: A vizsgált intézmények beutazó Erasmus hallgatóinak a száma (buborék nagysága) az összes és a külföldi hallgatók számának függvényében

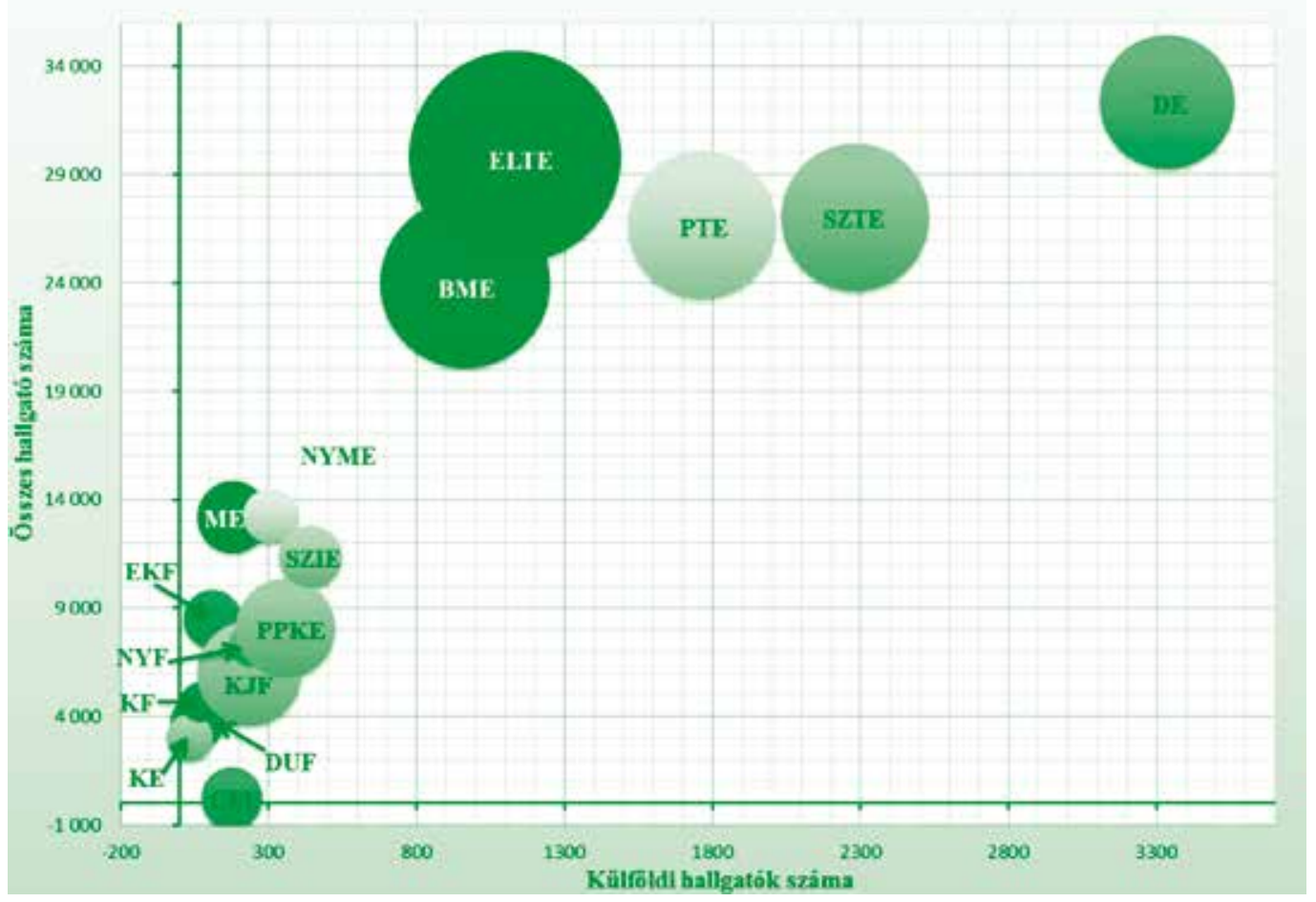

Forrás: EMMI és TKA adatközlés

\subsection{A mobilitást befolyásoló intézményi tényezők rendszerezése}

A korábbi kutatások döntően a hallgatók, kisebb mértékben az oktatók (Rédei-Telbisz-Nemes-Nagy 2007), illetve az adminisztratív dolgozók szempontjából értékelték a mobilitást befolyásoló tényezőket. Miután a hallgató a kulcsszereplője a mobilitásnak, ez továbbra is így lesz, ugyanakkor ha változást akarunk elérni, akkor az intézményi, szervezeti kérdések válnak meghatározóvá. Ezeknek a kutatása viszont sokkal bonyolultabb, minthogy a szervezet számtalan jellemzőjének ismerete nélkül nehéz értékelni a mobilitásra vonatkozó jellemzőket.

A kutatást az intézmények átfogó elemzésére, a 2013-as esztendő sajátosságaira, a honlapok és egyéb dokumentumok szelektív információira és egy holisztikus megközelítésre alapoztuk. Minden intézménynél, néhány kivételtől eltekintve, egy-egy oktatói hátterű felsővezetővel (rektor, rektorhelyettes, dékán), valamint egy-egy nemzetközi ügyekért felelős adminisztratív vezetővel (nemzetközi osztály-, csoportvezető, külügyi referens, mobilitási koordinátor, stb.) készítettünk interjút. Az interjú vezérfonala egy két oldalas dokumentum (5.1. melléklet), amelyet maximalista módon, a TKA munkatársainak a közremüködésével állítottunk össze. A kérdések átfogóak, amelyekre adott válaszok személytől, szakterülettől és beosztástól függően meglehetősen szubjektívek és terjedelmesek lehetnek. Emiatt nem az interjúk 
leírására, visszaadására törekedtünk, hanem az adott intézmény jellegzetességeinek a megrajzolására. Az egységességet az intézményfejlesztési tervekből vett mobilitási adatok (táblázatok) szolgáltatták.
Az interjú vezérfonal hét nagy témakört ölelt fel, amelyek a következők:
1/ Az intézmény néhány számszerü jellemzője a mobilitás szempontjából
2/ Intézményirányítás, vezetői elköteleződés
3/ Intézményi folyamatok, szabályzatok, információáramlás
4/ Finanszírozás a nemzetközi tevékenységben
5/ Minőségbiztosítás, nemzetközi elismerések, akkreditáció
6/ Oktatásszervezés, a nemzetközi hallgatók elkülönülése
7/ Emberi erőforrások menedzselése, ellátottság

A megkérdezettek szabadon fejtették ki a véleményüket, amelyek gyakran kritikusak, máskor nagyon „elnézőek” voltak, és emiatt elsősorban nem a mini esettanulmányokban jelenítettük meg, hanem az öszszefoglaló következtetésekben. Az esettanulmányokban a pozitív részekre helyeztük a hangsúlyt, mert az a véleményünk, hogy mindenkitől lehet tanulni, illetve az élenjáróknak is van tanulnivalójuk, ha a céljaikat magasabb szinten tűzik ki. Megközelítésünk a szervezetelmélet kontingencia elméleti irányzatát tekinti alapnak, amely szerint a konkrét szervezeti megoldások (konfigurációk), a szabályozottság vagy a specializáció mértéke nem általában, hanem konkrétan, az adott intézmény kontextuális jellemzőitől függően határozható meg. Más szóval pl. a nemzetközivé válás szempontjából alacsony mobilitási adatot ugyan kritizálhatjuk kívülről, de ha az intézmény más prioritásokat sikeresen követ, akkor az egyedi esetben nem marasztalható el. Nem kívánunk tehát direkten tanácsot adni egyetlen intézménynek sem, ugyanakkor a kérdéseinkre adott bizonytalan válaszok gyakran elgondolkodtatták őket, ami ígéretes attitűdváltozást is jelenthet.

A tanulmányban gyakran építünk a honlapokról vett idézetekre, amelyek olyan témákat érintenek, amelyek megjelentek az interjúkban is, de az idézetek szakszerűbben tájékoztatnak arról, hogy miben is áll a jelenség, probléma vagy megoldás lényege. Tanulmányunk egyik célja, hogy a mobilitást ösztönző pozitív példákat mutassunk be, és felhívjuk rá a figyelmet, hogy mások is tanuljanak belőle. Szolgáljon itt például az Erasmus Diák Hálózat (ESN) egyik legutóbbi felhívása a Corvinus Egyetem gyakorlatából, amely 2013. augusztus 14-én jelent meg a honlapon: „Az ESN Corvinus egy non-profit diákszervezet, melynek elsődleges célja az egyetemen tanuló külföldi cserediákok közösségbe való integrációjának támogatása. Ennek érdekében közös programokat, kirándulásokat, kulturális eseményeket szervezünk a külföldről érkező cserediákoknak, emellett a tandemprogramért is mi vagyunk a felelősök. És hogy miért érdemes belépni? Mert tagja lehetsz egy nagyon jó csapatnak, megismerkedhetsz több kultúrával, mert nagyon jó szervezőkészség-fejlesztési és nyelvgyakorlási lehetőség, valamint mert egy nagyon nagy buli az egész, sok jó fej emberrel! A bevonótábor ideje: Augusztus 18-19. További információkat találhattok a facebook eseményen: https:/www.facebook.com/events/ 499215r76827563."

Végezetül utalunk arra, hogy a nemzetközi ügyekért felelös rektor és dékán helyettesek megnevezése nagy változatosságot mutat a magyar felsőoktatásban. Kováts (2012) kutatásai kimutatták, hogy 28 felsőoktatási intézményből 11 esetben volt megnevezve „nemzetközi rektor helyettes”, míg a 150 karra kiterjedő vizsgálatnál 14\%-ban jelent meg a nemzetközi terület a dékán helyettes nevében. 


\section{A vizsgálatba bevont intézmények mobilitási jellemzői és akadályozó, ösztönző tényezői - intézményi esetek}

A mobilitást akadályozó és ösztönző intézményi tényezők témakörében folytatott interjúk elején nagyvonalakban áttekintettük a felsőoktatási intézmény mobilitását jellemző fő statisztikai adatokat. Minél nagyobb intézményről van szó, annál inkább szerteágazó és esetleges azoknak az információknak a köre, amellyel az egyes személyek rendelkeznek. Az interjúra való felkészülést szolgálta az intézmény mobilitási jellemzőinek összegyüjtése a FEMIP honlapon található intézményfejlesztési tervek adatbázisa segítségével. Minden egyes intézményi esetet a szervezeti egységek (karok, intézetek, stb.) hat mobilitási jellemzőjének bemutatásával kezdünk. Az interjú folyamatossága érdekében, a megkérdezett személyt nem kényszerítettük arra, hogy emlékezzen ezekre a statisztikákra, de alapul szolgáltak ahhoz, hogy a kérdések célirányosak lehessenek, illetve a mobilitási kontextus (az 1. fejezetben tárgyalt témakörökkel együtt) az olvasó számára is egyértelmű legyen. Az itt következő táblázatok hat sorához a következő megjegyzéseket füzzük:

1. A külföldi hallgatók arányát tekintve nagyon eltérő statisztikák jelennek meg a közbeszédben. Gyakran csak a legjelentősebb „tételt” jelentő nappali, diplomát nyújtó képzésen tanuló külföldi hallgatókról beszélnek. Máskor minden képzési program megjelenik, illetve bekapcsolódik a csere illetve a részképzés is. Természetesen minden megoszlás számbavételének van értelme, de a mi kutatásunk szempontjából a minél átfogóbb, a teljes sokaságot jellemző fajlagos és abszolút számok a relevánsak. Emiatt a külföldi hallgatók aránya jelenti az összes rész- vagy teljes idejű képzésben tanuló külföldi hallgató arányát az összes hallgatóhoz képest, a tanév október 15-én mért állapota alapján.

2. A külföldi részképzésben részt vevő hallgatók aránya az összes hallgatóhoz képest szintén egy adott időpontra vonatkozik. Amennyiben a tavaszi szemeszterben is annyi hallgató tanul külföldön, mint ősszel, továbbá mindenki csak egy félévet tölt külföldön, akkor ennek a százalékos értéknek a kétszerese az, ahány hallgató megfordult külföldön az adott évben.

3. A kiutazó alkalmazottak aránya együttesen tartalmazza a kiutazó oktatók és személyzet (nem oktatói státuszban dolgozó alkalmazottak) arányát a teljes alkalmazotti létszámhoz képest. Ezek a számok csak részlegesen fejezik ki a „nemzetközi kitettséget”, ahhoz képest, ahogyan azt az első fejezetben (a teljes munkaidőre vonatkoztatva) definiáltuk. Itt egybeolvadnak a rövid (2-5 napos) és a hosszabb (több hetes, hónapos) külföldi tartózkodások, mert a kiutazásban érintettek számbavételén van a hangsúly.

4. Az idegen nyelven meghirdetett szakok száma kifejezi azt a képességet, hogy egy kar, egyetem mennyire képes integrálódni a globális mobilitásba. Szakok híján nincs lehetőség fizetős hallgatók fogadására, továbbá egyéni erőfeszítéseken múlik, hogy milyen kiszolgálásban részesülnek a cserehallgatók.

5. A joint degree jellegü, közös képzési együttmüködések száma is nagyon nagy változatosságot mutat, ahol az együttműködés tartalma is igen eltérő lehet. Itt szerepelnek a kettős diplomát (double degree) nyújtó programok, amelyek létrehozása és szenátus által történő elfogadtatása egyszerübb, mint a közös diplomáé. Az intézményfejlesztési tervek sem a múltra, sem a jövőre vonatkozóan nem tartalmaznak bőséges adatokat ezen a téren. Az ilyen tartalmú statisztikák összesítése (Berács et al. 2013: 63. o. 4.3. ábra) is meglehetősen bizonytalan, mert a laza megnevezés miatt 
(,joint degree jellegű képzés”) az intézmények szubjektív besorolást végeztek. Ezen a helyzeten változást az alapján várhatunk, ha nő ennek a formának az intenzitása és a sikeres példák szélesebb körben terjednek, amihez nagyban hozzájárulhat a JOIMAN projektről megjelent kiadvány olvasása. $^{3}$

6. A nemzetközi intézményi partnerkapcsolatok száma nagyon heterogén mutató és feltehetőleg sok szubjektív elemet is tartalmaz ahhoz képest, hogy pl. hány Erasmus vagy CEEPUS együttműködési szerződéssel rendelkezik az intézmény. A nagyságrendek azonban eligazítanak abban, hogy milyen mértékű a nemzetközi orientáció a szervezetben.

Az interjú korlátozott időtartamára tekintettel, az interjú vezérfonalául meghatározott hét témakört, illetve a mobilitást jellemző hat jellemzőt egyféle mátrixként fogtuk fel és hagytuk, hogy az interjúalanyok a maguk szempontjából fejtsék ki véleményüket. Az IFT-ben szereplő adatok egyáltalán nem közismertek a felsővezetők számára. Gyakori válasz volt, hogy ha pontos adatra van szükség, akkor majd utánanéznek, és tájékoztatnak róla. Számunkra viszont éppen az volt a lényeges, hogy maguktól mit mondanak az interjúalanyok, mindenféle előzetes felkészülés nélkül. (Leszámítva a felkérő levelet, amelyben vázoltuk a kutatási feladatot, illetve az interjú vezérfonalában szereplő hét témakört.) Éppen ezért a nagy egyetemek esetében nem tekinthető feltétlenül reprezentatívnak, amit kiemeltek.

A megkérdezettek eltérő szakmai tapasztalattal rendelkeztek. Voltak, akik most vették át a pozíciójukat, és sokkal inkább a terveikről, mint a tényleges folyamatokról beszéltek. Mások több évtizedes gyakorlati munka után, a feladatukkal azonosulva, az elért eredményeket egyben az életművük megkoronázásaként is tekintve, negatívan élik meg a jelenlegi költségmegszorításokat, amelyek a nemzetközi területen is pénzügyi, illetve státuszcsökkenéshez vezettek. Ez utóbbi azt is jelenti, hogy a megnövekedett külföldi hallgatókra kisebb figyelem fordítódik, holott a szándék ennek éppen az ellenkezője. Az eltérő helyzetek miatt egy ilyen rövid interjú nem alkalmas arra, hogy az egyes munkatársak munkaidő kihasználását, hatékonyságát megítéljük.

\subsection{Pécsi Tudományegyetem}

A Pécsi Tudományegyetem a három nagy vidéki univerzitás tagjaként, valamikor 33000 hallgatóval is rendelkezett, amely létszám mára 26000 före csökkent. Egyidejűleg a külföldi hallgatók száma töretlenül növekedett és a 2012/2013-as tanévben elérte a 2500 főt (ebből 1900 fö az Általános Orvostudományi Karon tanult), azaz az összes hallgató közel 10\%-át. Az ÁOK minden második hallgatója külföldi, míg a bölcsész (BTK) és a közgazdász (KTK) karokon minden 20. hallgató jött külföldről. Ezen a három karon van idegen nyelven meghirdetett szak. A többi kar hallgatói csak elvétve találkoznak külföldi diákkal (arányuk az 1\% körül szóródik).

\footnotetext{
3 A közös képzések iránti érdeklődést nagyban felerősítette az Erasmus Mundus program 2004-2008 között megvalósuló első fázisa. Ennek hatására alakult meg 2008-ban a Bolognai Egyetem szervezésében 15 európai egyetem, illetve három Erasmus Mundus nemzeti iroda közreműködésével a JOIMAN hálózat. A hálózat célja a közös képzések szervezésével kapcsolatos kérdések megoldása. A tevékenységükről megjelent beszámoló a témakör iránt érdeklődők számára nyújt elengedhetetlen segítséget, fogalmi tisztánlátást, illetve tevékenységi útmutatást. (JOIMAN 2013, szerk. Jánosik Orsolya - Dobos Gábor, Tempus Közalapítvány)
} 
6. táblázat: A Pécsi Tudományegyetem nemzetközi mobilitását jellemzö fö adatok szervezeti egységek szerint (2010/2011)

\begin{tabular}{|c|c|c|c|c|c|c|c|c|c|c|}
\hline Jellemzők & ÁJK & ÁOK & BTK & ETK & FEEK & IGYK & KTK & MK & PMMK & TTK \\
\hline $\begin{array}{l}\text { Külföldi hallgatók } \\
\text { aránya (\%) }\end{array}$ & 0,71 & 51,53 & 5,13 & 1,11 & 1,06 & 0,08 & 4,69 & 4,47 & 1,44 & 0,79 \\
\hline $\begin{array}{l}\text { Külföldi részkép- } \\
\text { zésben részt vevo" } \\
\text { hallgatók aránya } \\
(\%)\end{array}$ & 1,37 & 0,95 & 3,00 & 1,07 & 0,87 & 0,92 & 2,72 & 2,63 & 0,90 & 1,06 \\
\hline $\begin{array}{l}\text { Kiutazó alkalma- } \\
\text { zottak aránya (\%) }\end{array}$ & 20,18 & 0,78 & 7,12 & 1,29 & 18,06 & 16,26 & 14,29 & 7,05 & 3,11 & 6,74 \\
\hline $\begin{array}{l}\text { Idegen nyelven } \\
\text { meghirdetett } \\
\text { szakok száma }\end{array}$ & 0 & 6 & 4 & 0 & 0 & 0 & 4 & 0 & 0 & 0 \\
\hline $\begin{array}{l}\text { Joint degree } \\
\text { jellegü, közös kép- } \\
\text { zési együttműkö- } \\
\text { dések száma }\end{array}$ & 2 & $\mathbf{0}$ & 1 & 0 & 1 & 0 & 3 & 0 & 0 & 0 \\
\hline $\begin{array}{l}\text { Nemzetközi } \\
\text { intézményi part- } \\
\text { nerkapcsolatok } \\
\text { száma }\end{array}$ & 62 & 352 & 198 & 27 & 5 & 18 & 29 & 15 & 3 & 618 \\
\hline
\end{tabular}

Forrás: www.femip.hu Intézményfejlesztési tervek TABL_17 és TABL_27

Az egyetemi vezetés elkötelezett a nemzetközivé válás iránt, ami megjelenik a küldetésnyilatkozatukban is, de a mobilitásra vonatkozóan nem tűztek ki konkrét stratégiai célokat, amit egyetemi illetve kari szinten el kellene érniük. A Szentágothai János Kutató Központ ${ }^{4}$ jeleníti meg legplasztikusabban a tudományos elköteleződést, a Nemzetközi Tudományos Tanácsadó Testület megalakítása pedig a folyamatos külső kontroll igényét. A diplomáért tanuló külföldi hallgatók létszámát évről évre 300 fővel, azaz több mint 10\%-kal kívánják növelni. A csökkenő egyetemi bevételekből (amely nagysága a 2011-es esztendőben még közel 60 milliárd volt az IFT szerint: femip.hu, TABL_29) becslés szerint 3,3 milliárd forintot tett ki 2012-ben a külföldi hallgatóktól származó bevétel.

4 „A Pécsi Tudományegyetem a mintegy hétmilliárd forintos európai uniós támogatásból megvalósult, az építése során átmenetileg Science Building névre hallgató kutatóközponttal a természettudományi, orvostudományi és műszaki oktatás, kutatás és innováció számos területének fejlesztését célozta meg. A projekt révén olyan új laboratóriumok, kutatóműhelyek jöttek létre, amelyek infrastrukturálisan az európai élvonalba tartoznak, és amelyekhez hasonló - néhány szakmában - jelenleg nincs Magyarországon." (2012. október 29.) Forrás: www.szkk.pte.hu/index.php?r=media/new\&id=37 
A külföldi diplomakredites hallgatók legtöbben Németországból (571), Norvégiából (225) és Iránból (135) érkeztek a 2011/2012-es tanévben. A szomszédos országok magyar anyanyelvű hallgatói, a földrajzi elhelyezkedés miatt, alulreprezentáltak más nagy egyetemekhez képest. A legtöbben (82) Szerbiából érkeztek, de tízszer kevesebben, mint amennyi szerb állampolgár Szegedet választotta. Erasmus keretében 400 magyar hallgató ment külföldre, és 300 külföldi érkezett a PTE-re, ahol a negatív egyenleg mérséklődött, elsősorban amiatt, hogy az anyagi gondok miatt kevesebben választották a külföldi tanulmányokat. Jelentős siker, hogy a 197 jelentkezőből 192 fő nyert el Campus Hungary ösztöndíjat az elmúlt tanévben, ami lényegesen megemelte az összességében külföldön tanuló hallgatók számát és arányát. Az egyetem 6 CEEPUS programban érintett, amelyben 60 fő vett részt. Megnőtt az oktatók mellett a nem oktató személyzet kiutazása is (a FEEK, azaz a Felnőttképzési és Emberi Erőforrás Fejlesztési Kar vezeti a karok listáját 18\%-kal), amely alapja lehet az idegen nyelvű képzés fejlesztésének. A nem oktatói, adminisztratív személyzet mobilitását segítette, hogy nyelvkurzusra is lehetett jelentkezni külföldre, így kitágult a potenciális résztvevők köre, hiszen a megfelelő szintű nyelvtudás sok területen hiányzik.

Állami ösztöndíj és magánfinanszírozás áll a döntően művészeti és építészeti területre koncentráló, Dél-Koreát, Japánt és Vietnámot megcélzó, évente 25 hallgató ki- és beutazását lehetővé tevő mobilitási program mögött. Dél-Koreából 2011/12-ben a PTE fogadta a legtöbb hallgatót (85 fö) Magyarországon, míg Vietnámból akkor egyetlen hallgató sem érkezett diplomaszerzésre. Mérsékelt létszámban az USA csereprogramok is jelen vannak, amelyek presztízsértékűek, de túl sok energiát kötnek le, így a lassú növekedés a cél.

Az intézményi folyamatok, a központ és a szervezeti egységek közötti információáramlás összehangolása a programok mérete és történelmi kialakulása folyamán is heterogén. Az egységesítés irányába mutat, hogy az Erasmus program bonyolítása az Oktatási Igazgatósághoz került, ilyen módon mind a hazai, mind a külföldi hallgató az Elektronikus Tanulmányi Rendszer (ETR) keretében azonos felületen tud tárgyakat felvenni és választani. Ennek következtében megnyílt a lehetősége a karok közötti áthallgatásnak is, amelyre pl. a kreditszám kitöltése miatt is szükség lehet, ha egy-egy tárgy, az alacsony létszám miatt nem indul el. Becslés szerint a 600 részidős külföldi hallgatóból kb. 50 fó élt ezzel a lehetőséggel, hogy más karon is vett fel kurzust, mint amihez tartozik. Magyar hallgatók számára, akik nem idegen nyelven tanulnak, nincs annak szervezett és kötelező rendszere, hogy bizonyos tárgyakat, kreditszámot idegen nyelven hallgassanak. Ugyan létezik a karok közötti áthallgatás, de ennek adatai, költségei nem köztudottak.

A nemzetközivé válás eltérő szintjein elhelyezkedő szervezeti egységek, karok tájékoztatását szolgálja a belső marketing akció (,belső roadshow”) amelynek keretében a központi nemzetközi iroda munkatársai tájékoztatást, konzultációt tartanak a társszervezeteknek. Meggyőzésre van szükség a kredit mobilitás rugalmas érvényesítésére, a hallgatói szolgáltatások fejlesztésére.

Ugyancsak nagyobb meggyözésre van szükség a hallgatók irányában, hogy a külföldi tapasztalatszerzés mellett döntsenek. A legnagyobb korlátozó tényező a diákok által is hangoztatott anyagi oldal, és a költségvetési megszorítások miatt csökkent az egyetem, a karok áldozatvállalása is ilyen célokra. Bizonyos szakokon (pl. közgazdasági, jogi, gazdálkodási, stb.) a képzés döntően fizetőssé vált, emiatt a családok kevésbé tehetik meg, hogy még külföldre is küldjék gyerekeiket. A diákok egyre nagyobb része folyamatosan dolgozik a finanszírozási forrás elöteremtése érdekében, ami szintén a mobilitás ellen hat. A kreditelismertetés bonyodalmai, valamint a kétszintű, rövidebb bolognai képzés további rendszerszintű korlátozó tényezők, amelyeket a humán erőforrásnak kell ellensúlyoznia.

Egyetemi központi szervezetben jelenleg 4 főt foglalkoztatnak a nemzetközi irodán, és 3 főt az Oktatási Igazgatósághoz tartozó Erasmus irodában. Egy új TÁMOP keretében lehetőség lesz 1 fővel bővíteni a központi szervezetet, akinek a feladata az értékesítés elősegítése lesz. A karokon 1-3 fő (átlago- 
san 2 fö) foglalkozik fóállásban, nemzetközi tevékenységgel, adminisztratív területen. Mindösszesen 28 fös adminisztratív munkaerő áll rendelkezésre a 2500 külföldi hallgató, a kb. 800 kiutazó magyar hallgató és az 1000 főre tehető ki- és beutazó alkalmazott kiszolgálására.

\subsection{Kaposvári Egyetem}

A 2000-ben két kar és két intézet integrációjával megalakult új egyetem ma négy karral működik. Fénykorában, 2005-ben közel 5000 hallgató folytatott itt tanulmányokat, akik száma mára, a megújult és közel 15000 négyzetméter új infrastruktúrával bővült impozáns campuson, 3000 főt közelíti. Ez is jelzi, hogy nincs könnyü helyzetben az egyetem vezetése. A honlapon 2013. augusztus elején ingyenes nyelvi tanfolyamokat hirdetnek azok számára, akiknek még nincs nyelvvizsgájuk és emiatt nem tudják a diplomájukat átvenni. Ez utóbbiak aránya országos rekordot döntött 50\%-kal, ami jelzi, hogy az ide kerülő hallgatók szociális háttere sem lehet túlságosan kedvező.

7. táblázat: A Kaposvári Egyetem nemzetközi mobilitását jellemzö fó adatok szervezeti egységek szerint (2010/2011)

\begin{tabular}{|c|c|c|c|c|}
\hline Jellemzők & $\begin{array}{l}\text { Állattudományi } \\
\text { Kar }\end{array}$ & $\begin{array}{l}\text { Gazdaságtudomá- } \\
\text { nyi Kar }\end{array}$ & $\begin{array}{l}\text { Pedagógiai } \\
\text { Kar }\end{array}$ & $\begin{array}{l}\text { Művészeti } \\
\text { Kar }\end{array}$ \\
\hline $\begin{array}{l}\text { Külföldi hallgatók } \\
\text { aránya (\%) }\end{array}$ & 2,0 & 0,7 & 0,2 & 0,5 \\
\hline $\begin{array}{l}\text { Külföldi részképzés- } \\
\text { ben részt vevő hallga- } \\
\text { tók aránya (\%) }\end{array}$ & 0,3 & 0,4 & 0,3 & 2,9 \\
\hline $\begin{array}{l}\text { Kiutazó alkalmazottak } \\
\text { aránya (\%) }\end{array}$ & \multicolumn{4}{|c|}{1,7} \\
\hline $\begin{array}{l}\text { Idegen nyelven meg- } \\
\text { hirdetett szakok száma }\end{array}$ & 1 & 1 & 0 & 0 \\
\hline $\begin{array}{l}\text { Joint degree jellegü, } \\
\text { közös képzési együtt- } \\
\text { működések száma }\end{array}$ & 0 & 0 & 0 & 0 \\
\hline $\begin{array}{l}\text { Nemzetközi intézmé- } \\
\text { nyi partnerkapcsola- } \\
\text { tok száma }\end{array}$ & \multicolumn{4}{|c|}{76} \\
\hline
\end{tabular}

Forrás: www.femip.hu Intézményfejlesztési tervek TABL_17 és TABL_27

A rész- vagy teljes idejű képzésben tanuló külföldi diákok aránya az összes hallgatóhoz képest egyetemi szinten 0,7\%, amelyből az Állattudományi Kar emelkedik ki 2\%-kal. Évente tehát néhány tucat 
külföldi diák jelenik meg a két idegen nyelven meghirdetett mester szakon, amelyek közül eddig az Állattudományi karon indult el a képzés, és két év után 9 fó végzett is az állati táplálkozással és élelmiszerbiztonsággal foglalkozó szakon. A hallgatók elsősorban a fejlődő, az ún. harmadik országokból jöttek, akiknek a tandíját a FAO, a magyar kormány, illetve a saját nemzeti kormánya fizette. Ennek hiányában egy éve nem indult el a képzés, de remélik, hogy 2013-ban újra el tudják indítani.

A Gazdálkodástudományi Kar által akkreditált, a környezetvédelemmel foglalkozó mesterképzésre még nem sikerült elegendő számú hallgatót toborozni. Új lendületet adhat a programnak is, hogy erre támaszkodva, egy közép-európai konzorcium részeként, egy új joint degree programot dolgoztak ki, a konzorciumot vezető szerb magánegyetem kezdeményezésére. Az Alliance of Central-Eastern European Universities $\left(A C E U^{5}\right)$ öt kisebb, részben magán egyetem társulása (Újvidék, Bukarest, Eperjes, Kaposvár, Szkopje helyszínnel). A „Green MBA”-nek is nevezett közös szak hallgatóinak legalább három egyetemen kell egy-egy szemesztert eltölteni, mielőtt megírják a diplomamunkájukat az anyaintézményben. A társulás célul tűzte azt is, hogy a kormányzatokat segítik, illetve tanáccsal látják el az oktatáspolitika alakítása érdekében, hogy a közepes méretű, magán és vidéki egyetemek számára is releváns irányokat határozzanak meg. A honlapukon (http://www.aceu-edu.org) részletesen kifejtik, hogy miként kívánnak értéket teremteni a partneri kapcsolatok fejlesztésével, hogy az oktatás és kutatás területén hozzájáruljanak az innovatív tudás alapú gazdaság megteremtéséhez. Az öt alapító tag mellett már újabb 6 egyetem is társult a konzorciumhoz Albániából, Bosznia-Hercegovinából, Bulgáriából, Montenegróból, illetve Szlovéniából.

Az egyetem három évvel ezelőtt indította el a nemzetközi nyári egyetemét (International Summmer School - ISS), amelyen évente más és más tematika alapján, külföldi tanárok bevonásával kínált angol nyelven (egyszer orosz nyelven is) két hetes programot a világ bármely részéről ide érkező diákoknak, akik a tanulmányokért 6-8 kreditet is kaphatnak, ha eleget tesznek a számonkérési követelményeknek. (http://iss.ke.hu) A magas tandíj, illetve a korlátozott ösztöndíj/támogatás miatt magyarok csak elvétve vesznek részt a programban. Az első évben a Voronyezsi Egyetem 20 hallgatója töltötte meg a padokat. Az idei program a"zöld gazdaság” címszava alatt a szeptemberben induló ACEU MBA program számára is kedvcsináló akart lenni. Azerbajdzsánból vártak egy nagyobb hallgatói kontingenst, de végül elmaradtak. Az idei esztendő fontos volt a Művészeti Kar számára, mert Vidnyánszky Attila a Színházi Intézet igazgatója (a Nemzeti Színház új igazgatója) meghívta a 2 hetes nemzetközi mesterkurzusra a világhírü orosz Rizsakov rendezőt, aki hozott magával 25 orosz színházi hallgatót is.

A tanterv összeállitásánál egyelőre elválik a magyar és az idegen nyelvű képzés. Alacsony szintű (becslés szerint csak 10\% rendelkezik ilyen nyelvtudással) a magyar hallgatók kurzusfelvételi hajlandósága. Hatékony viszont a hallgatói tutori rendszer az Erasmus programban, amely hatására nő a jelentkezők száma. Így pl. a török hallgatók mellé rendelt magyar tutorok a következő esztendőben jelentkeztek török egyetemekre, a személyes kapcsolatok hatására.

Az SZMSZ-ben is rögzített szervezet, a Nemzetközi Kapcsolatok Bizottság, amelynek a vezetője a Nemzetközi Kapcsolatok Iroda igazgatója, tagjai a négy kar, három független intézmény és a hallgatók képviselője mellett az egyetem főtitkára. A bizottság feladata javaslatok készítése az egyetem vezetése és a szenátus számára a nemzetközi kapcsolatok fejlesztése érdekében. Értékeli és összehangolja az intézmények nemzetközi munkáját, meghatározza a nemzetközi kapcsolatok, a hallgatói és alkalmazotti

5 ,The Alliance of Central-Eastern European Universities is made up of universities, service providers and other key stakeholders in the region. Members work together to enhance the quality of higher education, to facilitate high-level cooperative research, and to strengthen the region's knowledge-based economy. These goals are accomplished by sharing resources and expertise, collaborating on workshops and publications, organizing programs of mutual interest, and promoting intra-ACEU mobility of students and staff. Members of the ACEU also mutually support one another's applications and proposals to third-party institutions and often apply jointly." http://english.ke.hu 
mobilitás prioritásait, a partneri kapcsolatok irányait. A két éves múlttal rendelkező szervezet még nem tudja teljesíteni a számára kitűzött célokat. Az ISO minősítéssel is rendelkező egyetem információs folyamatai szabályozottak, amelyben a nemzetközi aspektus a jelenlegi szerepének megfelelő súlyt kap.

A Nemzetközi Kapcsolatok Irodában két fóállású adminisztratív munkatárs dolgozik akiket részidőben vezet a széleskörű nemzetközi kapcsolatokkal és tapasztalatokkal rendelkező igazgató, egyetemi docens. A karokon oktatói Erasmus felelősök vannak. Az új vezetés felismerte a nemzetközi tevékenység fontosságát, a keleti és a közép-európai nyitás jelentőségét, de az egész egyetemi humán infrastruktúra (az oktatóktól az adminisztratív munkatársakig) még nem felkészült nagyobb ütemű fejlődésre. Sokat kell tenni a külföldieket elválasztó kulturális távolság leküzdésére.

Az egyetem valaha 7 milliárd forint körüli költségvetése 2,5 milliárd forintra apadt, amelyben nincs külön kerete a nemzetközi tevékenységnek. A nyári egyetemeknek van önálló költségvetése, saját számlája. A fizetős programok között említésre méltó a két angol nyelven is meghirdetett $\mathrm{PhD}$ program, amelyen 3 német hallgató is van a Gazdálkodástudományi Karon, míg a brazil program keretében egy hallgató érkezik szeptemberben az Állattudományi Karra.

\subsection{Kodolányi János Főiskola}

Az elmúlt néhány év egyik legnagyobb vesztese, ami a hallgatói létszámot illeti, a nagyon ambiciózus célokat ${ }^{6}$ maga elé tűző Kodolányi János Főiskola, amely mint magániskola próbál meg új stratégia alapján szervezetileg és hallgatói létszámot tekintve is konszolidálódni. A 2004/2005-ös tanévben még 10 712 hallgatót regisztráló főiskola a 2013/14-es tanévben már csak 4000 fő alatti felsőoktatási diákkal számol. (Stratégiai szempontból is fontos a tanárképzési szakkal is rendelkező főiskola számára, hogy egy 1200 fős gimnáziumot is működtet Székesfehérváron, amely a nyelv, az EU-s ismeretek mellett a sport és életpálya ismeretekre is szakosodik.) A több telephellyel rendelkező intézmény hallgatóinak többsége ma már Budapesten tanul. Ebben nagy része van annak is, hogy gyakorlatilag megszűnt az állami támogatás.

A csúcsra járatás időszakában még 4,5 milliárd forintos költségvetéssel dolgozó intézmény mára 2,4 milliárd forinttal kalkulálhat. Ebből kell a korábbi magas minőségi célokat megvalósítani, mint például, hogy a fokozattal rendelkező tanárok aránya továbbra is $90 \%$ maradjon vagy, hogy a székesfehérvári helyszínen is folyó képzésekért megítélt minőségi díjakra, amelyeket büszkén hirdetnek, továbbra is rászolgáljanak.

„Az Intézet nemzetközi mobilitás területén nyújtott munkáját a 2006-os évben az E-Quality Európai Minőségi Díjjal, míg 2010-ben Nemzetközi együttműködési kultúráért nívódíjjal ismerték el. Az épületnek ugyanebben a szárnyában működik a Kommunikációs Központ, valamint az e-learning alapú tananyagok fejlesztésért és a távoktatásban induló képzések koordinációjáért felelős Nemzetközi Képzési Központ. Az intézet több mint 600 diák oktatását koordinálja. Kiemelkedő minőségű elektronikus oktatási anyagainak köszönhetően elnyerte a Magyar Minőség e-oktatás 2006 Díjat.” www.kodolányi.hu/helyszinek/szekesfehervar

\footnotetext{
6 „A Kodolányi János Főiskola a hazai felsőoktatás innovatív, minőségorientált, vezető non-profit intézményeként regionális, országos humán erőforrás fejlesztési és innovációs funkciót tölt be. A hazai felsőoktatás vezető non-profit intézményeként országos szerepkörü, nemzetközi képzési orientáltságú, alkalmazott kutatással foglalkozó intézményként, oktatási - kutatási - szakmai tanácsadási kiválóságközpontként kíván tevékenykedni.

Küldetése, hogy hozzájáruljon az európai felsöoktatás versenyképességéhez, a magyar felsőoktatás nemzetközi integrációjához, Székesfehérvár Megyei Jogú Város regionális központ szerepének erősítéséhez, Orosháza térségében a turisztikai és rekreációs szolgáltatásokban innovációs centrumszerepkör megvalósításához, Budapest várostérségében a fóváros nemzetközi regionális központtá válásának segítéséhez. Tevékenységének célja a társadalmi minőség, mint érték érvényre juttatásának elősegítése.” www.kodolanyi.hu/foiskolarol/kuldetes
} 
Az intézményt már 2002-től vezető rektor nemzetközi elkötelezettsége kétségtelen. Arra készül, hogy a 3000 fő körül stabilizálódó hallgatói létszám mellett, folytatva a minden képzésre kiterjedő minőségi pedagógiai modellt, az intézmény bevételének 50\%-a már a nemzetközi tevékenységből fog származni 2020-ban. Ilyen kijelentést csak egy magánegyetem vezetőjétől hallottunk. Ehhez lényegesen meg kell növelni a fizetős részidős és diplomakredites hallgatók számát. Az 5\%, azaz 200 körüli külföldi hallgatóból (8. táblázat) ma még 180 fó a beutazó Erasmus hallgató. Évente 20 fö körül ingadozik a fizetős diplomakredites hallgató. A kimenő 140 hallgatóból az elmúlt tanévben már többen vettek részt szakmai gyakorlaton, mint egyetemi képzésen. A pozitív egyenleg a külföldi hallgatók javára, tükrözi a nemzetközi elköteleződést.

8. táblázat: A Kodolányi János Főiskola nemzetközi mobilitását jellemzőfő adatok (2010/2011)

\begin{tabular}{|l|l|}
\hline Jellemzők & \\
\hline Külföldi hallgatók aránya (\%) & 5,1 \\
\hline Külföldi részképzésben részt vevő hallgatók aránya (\%) & 3,3 \\
\hline Kiutazó alkalmazottak aránya (\%) & 12,5 \\
\hline Idegen nyelven meghirdetett szakok száma & 7 \\
\hline Joint degree jellegü, közös képzési együttműködések száma & 4 \\
\hline Nemzetközi intézményi partnerkapcsolatok száma & 400 \\
\hline
\end{tabular}

Forrás: www.femip.hu Intézményfejlesztési tervek TABL_17 és TABL_27

Az idegen nyelven meghirdetett 7 szakhoz képest is nagyon alacsony a fizetős hallgatók száma. Ennek megváltoztatására a keleti nyitás politikáját alkalmazták, de még nem sok sikerrel. Intenzív nemzetközi diplomáciai erőfeszítések, ügynöki szerződések hatására, 100 kinai és 80 indiai diák számára szerveztek egy éves előkészitő tanfolyamot, hogy majd elkezdhessék a főiskolai tanulmányaikat. Sajnos egy-két kivételtől eltekintve ezek a hallgatók eltűntek a rendszerből. Ugyanakkor azzal a problémával is szembesültek, hogy több odafigyelés kell a kulturális különbségek megértésére, illetve a város, a rendőrség, a Bevándorlási Hivatal nagyobb fogadó készségének az elérésére. Ezek a nem kívánatos események, a külföldiek nem megfelelő színben való feltűnése is hozzájárult a kudarchoz. A tanulság: fokozatosság a hallgatószámban, nagyobb körültekintés az ügynökök megválasztásában.

Jelenleg is sikeresen (nyereségesen) működik egy ukrán egyetemmel közös orosz nyelvű kihelyezett program Lembergtől $200 \mathrm{~km}$-re keletre. Egy másik ukrán egyetemmel a turizmus és a gazdálkodás és menedzsment mester szakokat távoktatási formában szeretnék kínálni. Jelenleg a piackutatás folyik. Kazahsztán és Azerbajdzsán is ígéretes piacnak tűnik, de megbízható együttműködő partner nélkül nem lehet belevágni. A kormányzat, a diplomáciai testület többet tehetne a siker érdekében. Nagy valószínüséggel itt is követtünk el hibát, hogy Nazarbajev kazah elnök magyarországi látogatása ellenére, nem sikerült bekerülnünk a kazah fiatalok külföldi tanulását segítő „Balasak” programba.

Külföldi telephelyként egy osztrák kisváros, Fürstenfeld jelenik meg, amely a nyugati stratégiai irányt hivatott megjeleníteni, egy 35000 lakosú városban, ahol nincs egyetemi szintű képzés. Másrészt 
folyik egy stratégiai egyetemi partner keresése is a nyugati világban, akinek a közreműködése révén a főiskola tulajdoni, irányítási rendszere is megváltozna.7 A minőségi pedagógiai elvekhez hozzátartozik a rendszeres mérés és folyamatos számonkérés. Régen minden hallgatónak a tanulmányai 30\%-át idegen nyelven kellett folytatnia, amire aztán nem figyeltek (megszüntették a nyelvi lektorátust) és most újra elő kell venni, mert romlott a nyelvtudás, a végzettek 20\%-a ennek hiánya miatt később kapja meg a diplomáját.

Minden tavaszi szemeszterben egy hét a nemzetközi hét, ahol pályázat alapján a partnerintézmények tanárai tartanak döntően órákat. Erre a hétre koncentrálják az Erasmus oktatói és adminisztratív személyzeti meghívásokat. A népszerűségét jelzi, hogy tavaly a 30 fő kiutazással szemben 40 fő volt a beutazó külföldi oktató és személyzet. Azok a hallgatók, akik nem vesznek fel idegen nyelven tárgyat, a szakhoz kötődően ún. „olvasási hetet” tartanak, amikor szakirodalmat olvasnak, és arról számolnak be. Az intenzív, 30 kontakt órát is tartalmazó héten a készségfejlesztésre helyezik a hangsúlyt.

A Nemzetközi Képzési és Szolgáltató Központ elnevezés már sejteti, hogy itt nem szokványos nemzetközi iroda működik, hanem egy szolgáltatást nyújtó intézmény. Az igazgató vezetése mellett 2 fö Székesfehérváron és 2 fó Budapesten tevékenykedik. Ha ehhez hozzávesszük a tanszékeken és az oktatási központokban tevékenykedők nemzetközi vonatkozású adminisztratív munkáját, akkor kb. 10 fővel számolhatunk. Ezek képzése, továbbképzése is fontos feladat, egyben kockázatos is, hiszen a versenytársak elcsábíthatják a legjobb munkatársakat.

\subsection{Dunaújvárosi Főiskola}

A Dunai Vasmű árnyékában felnövő, kohászati és gépészeti képzést nyújtó, a Miskolci Egyetem főiskolai karaként működő intézmény már régen a múlté. A piaci igények valamint az intézményi túlélés törekvése 2000-től önállóságot eredményezett, aminek következményeként 11 intézmény jött létre és a széles profil hatására, a fénykorában 5000 hallgató látogatta a PPP finanszírozásban korszerűsített infrastruktúrával rendelkező intézményt. Jelenleg 3500 hallgatóból 100 alatt van a külföldiek száma, akiknek a növelése stratégiai cél. Az IFT szerint 2016-ban évente 50-60 költségtérítéses külföldi hallgató felvételével számolnak. Erasmus keretében évente 20-30 fő utazik ki és be, érdekes módon a külföldi beutazók többletével.

Stratégiai elhatározást tükröz, hogy az intézmények átszervezésével, a profil fókuszálásával nem hoztak létre új karokat, hanem négy intézménybe szervezték a tanszékeket, és minden intézet idegen nyelven is meghirdet egy-egy szakot (9. táblázat).

Kettős diplomát a hollandiai Saxion Alkalmazott Tudományok Egyetemével ${ }^{8}$ közös programon szerezhetnek a hallgatók. A Gazdálkodástudományi Intézet által szervezett programon jelenleg két szakon lehet végezni, amit 2016-ra négy szakra kívánnak bővíteni. Három éves előkészítő munka előzte meg a szerződéskötést. A három éves BA képzésből egy évet kell a holland intézményben tölteni, ami a holland állami támogatás mellett is fizetendő évi 1781 eurós tandíj, valamint az utazási, szállás és megélhetési költségek, továbbá a gyenge nyelvtudás miatt nem eléggé vonzó a magyar hallgatók számára.

\footnotetext{
7 A Közép-európai Egyetem és az Andrássy Gyula Német nyelvű Egyetem mellett az IBS jelenik meg harmadik egyetemként Magyarországon (a külföldi egyetemek leányait nem számítva), ahol már a hallgatók többsége külföldi. Ez a stratégia az elmúlt két esztendőben térült meg igazán az IBS számára, amikor drasztikusan csökkent az újonnan felvett magyar hallgatók száma, különösen a főiskolákban.

8 „A Saxion Alkalmazott Tudományok Egyeteme az egyik legnagyobb felsőoktatási intézmény Hollandiában, amelynek több mint 22000 hallgatója van, közöttük 2500 külföldi. Hosszú felsőoktatási múlttal rendelkezik, - történelme 1875-ig vezethető vissza. A Saxion Egyetem három campus-on működik Hollandia keleti részén: Deventer, Enschede és Apeldoorn városaiban. A Saxion a különböző szintű képzések széles választékát kínálja hallgatói részére, beleértve számos nemzetközi képzési programot is. A Saxion Egyetem oktatásának minőségét a Holland Oktatási, Kulturális és Tudományos Minisztérium felügyeli, ezenfelül több nemzetközi testület akkreditációja is garantálja a hallgatóknak a választott területen oktatott képzési programok magas színvonalát." (www.duf. hu/képzesek/kettosdiplomas-kepzes/Saxion-egyetem)
} 
A végzős hallgatók 20-30\%-a a nyelvvizsga hiánya miatt nem veheti át a diplomáját. Ezzel a problémával a jövőben többet kell foglalkozni. Már most is minden beiskolázott hallgató vehet fel angol kurzust (amit a HÖK is többletponttal jutalmaz az ösztöndíj odaítélésénél), de ezt nem tették számukra kötelezővé, részben a törvényi korlátozások miatt. A gyenge nyelvtudás és a családi háttér miatt sem eléggé mobilak a hallgatók.

9. táblázat: A Dunaújvárosi Fơiskola nemzetközi mobilitását jellemző fó adatok szervezeti egységek szerint (2010/2011)

\begin{tabular}{|c|c|c|c|c|}
\hline Jellemzők & $\begin{array}{l}\text { Müszaki } \\
\text { Intézet }\end{array}$ & $\begin{array}{l}\text { Kommunikációtudo- } \\
\text { mányi és Tanárképző } \\
\text { Intézet }\end{array}$ & $\begin{array}{l}\text { Informatika } \\
\text { Intézet }\end{array}$ & $\begin{array}{l}\text { Gazdálkodástudo- } \\
\text { mányi Intézet }\end{array}$ \\
\hline $\begin{array}{l}\text { Külföldi hallgatók } \\
\text { aránya (\%) }\end{array}$ & \multicolumn{4}{|c|}{$2 \%$} \\
\hline $\begin{array}{l}\text { Külföldi részképzés- } \\
\text { ben részt vevő hallga- } \\
\text { tók aránya (\%) }\end{array}$ & \multicolumn{4}{|c|}{$0,5 \%$} \\
\hline $\begin{array}{l}\text { Kiutazó alkalmazot- } \\
\text { tak aránya (\%) }\end{array}$ & \multicolumn{4}{|c|}{$3 \%$} \\
\hline $\begin{array}{l}\text { Idegen nyelven } \\
\text { meghirdetett szakok } \\
\text { száma }\end{array}$ & 1 & 1 & 1 & 1 \\
\hline $\begin{array}{l}\text { Joint degree jellegü, } \\
\text { közös képzési együtt- } \\
\text { működések száma }\end{array}$ & 0 & 0 & 0 & 1 \\
\hline $\begin{array}{l}\text { Nemzetközi intézmé- } \\
\text { nyi partnerkapcsola- } \\
\text { tok száma }\end{array}$ & 8 & 6 & 5 & 3 \\
\hline
\end{tabular}

Forrás: www.femip.hu Intézményfejlesztési tervek TABL_17 és TABL_27

A brazil állam által támogatott Tudomány Határok Nélkül ösztöndíjprogram keretében természettudományos, mérnöki, egészség- és informatika tudományok területén, 2012 és 2015 között, 100 ezer brazil alap- és doktori képzésben tanuló diáknak nyílik lehetősége, hogy egy évet külföldi egyetemen töltsön. A hallgatók teljes képzési költségét és kiadásait a brazil kormány fedezi. A programot a Brazilian Federal Agency for Support and Evaluation of Graduate Education (CAPES), a program szervezéséért és lebonyolításáért felelős brazil állami ügynökség és a Magyar Rektori Konferencia koordinálja. A Dunaújvárosi Főiskola szeptembertől 20 hallgatót fogad az egy éves képzésre, akik közül 17 fő már el is kezdte a nyelvi előkészítőt. Ez már érzékelhető változást hoz a főiskola életében. A nagy kérdés, hogy 
fenntartható-e ez a viszonylag magas (a Magyarországra érkező 450 hallgatóból 4,4\%-os) részvétel, illetve hosszabb távon lesz-e hatása a diplomás képzésre.

A Főiskola 2010-ben nekiindult kihelyezett képzést szervezni Kinában. Hamar rájöttek azonban, hogy nehéz megfelelni a helyi kínai akkreditációnak. (Egyébként ezzel szembesültek a vezető angol egyetemek is, pl. a Nottinghami Egyetem, miként Ennew-Fujia (2009) beszámol róla, fontos a helyi partner szerepe.) Korábbi, időszakos sikerek voltak már 2006-ban is, amelyről a honlap is beszámol ${ }^{9}$, de igazi, tartós partneri (ügynöki) kapcsolatot a SQA-HND ígér. A skót SQA-HND rendszer (Scottish Qualification Award - Higher National Diploma) keretében a kínai diákok a skótok által Kínában szervezett egy éves nyelvi előkészítő, két éves szakmai képzés után egy évet, az alapképzés 3. évét Dunaújvárosban töltik, és itt kapnak diplomát. Mindezidáig 15 kínai diák érkezett ebben a formában a főiskolára, akik közül 9 fő szerzett diplomát. Erről a diplomaszerzési formáról, amely általános az angolszász területeken, a Wikipédia is beszámol ${ }^{10}$. Hosszútávon, a fejlődő világ fiataljainak korlátozott pénzügyi lehetőségeit ismerve, az ilyen „Szendvics programnak” is nevezhető rendszerek nagy piaci potenciállal rendelkeznek.

Az intézményi vezetés elköteleződése a nemzetközivé válás iránt a kiválasztott vezetők ilyen jellegü hátterének is a függvénye. Az oktatási rektor helyettes, aki a nemzetközi ügyeket is felügyeli, rendelkezik mind amerikai, mind kínai tanulmányi tapasztalatokkal, ami megkönnyíti, hogy a munkatársak kezdeményezéseit értően támogassa. Ezt jelzi, hogy már korán felismerték a műszaki területen is, hogy csak akkor indulhatnak jó eséllyel a nemzetközi mobilitásban, ha teljes programokat kínálnak angol nyelven. Ugyanakkor úgy látják, hogy nehéz eladni a „terméket”, részben azért is mert nincs megfelelő magyar nemzeti stratégia. Intenzívebb vásári, kiállítási részvételre lenne szükség.

Az ügynökökkel való szorosabb kapcsolatot az ICEF berlini rendezvényén próbálják megteremteni, amelyen 2 fővel vettek részt. Jelenleg 40 ügynöki szerződésük van (3 török, 2 kínai és kameruni, stb.) amelyek közül 12 az, amely komolynak tekinthető, azaz hallgató is származik belőle. Ezeket az eredményeket gyakran korlátozza a Bevándorlási Hivatal Székesfehérváron, amely nagyon kritikus, különösen az afrikai diákokkal. A vízumkiadástól függ, hogy szeptembertől 40 vagy 60 külföldi új hallgató kezdi meg a tanulmányait Dunaújvárosban. Egyébként elég jelentős a lemorzsolódás a következő esztendőben, részben Budapest, illetve más vidéki város elszívó hatása miatt. Mindezidáig becslés szerint 45 külföldi hallgató szerzett diplomát a Dunaújvárosi Főiskolán.

A minőségbiztositás vállalati filozófiáját követve a Dunaújvárosi Főiskola élenjáró intézmény Magyarországon, hiszen 2003-ban elsóként szerezte meg az ISO 9001-2000 szabványt, amit a norvég Det Norske Veritas Ltd. tanúsított. A Minőségirányítási Iroda 1996-ban alakult, és a vezetés mellett a munkatársak is elkötelezettek az ügy mellett. A tevékenységet részletesebben az 5.3. melléklet mutatja be. Az Iroda által végzett többkörös és időszakos hallgatói felmérések között még nem jelenik meg külön a külföldi hallgatók vagy a külföldön tanuló hallgatók felmérése. Az ISO filozófia biztosítja, hogy szervezett

9 A korai partnerkeresésről számol be a DF honlapja is. „2006-ban egy kínai ügynökségen keresztül Quingdao tartományból 26 kínai, a Donbass Ipari Szövetség Dunaferr Zrt., a Donbass Állami Műszaki Egyetem és a DF hármas együttműködésének köszönhetően 20 ukrán, interneten keresztül pedig három malajziai, egy kameruni és egy magyar hallgató jelentkezett a meghirdetett angol nyelvú képzéseinkre."

10 A Higher National Diploma (HND) is a higher education qualification of the United Kingdom. A qualification of the same title is also offered in Malta, Nigeria, and some other countries with British ties. This qualification can be used to gain entry into universities at an advanced level, and is considered equivalent to the second year of a three year university degree course. Edexcel describes an HND as „A vocational qualification, usually studied full-time, but can be studied part-time. It is roughly equivalent to the first two years of a 3 year degree (with honours), or to the Diploma of Higher Education". In England, Wales, and Northern Ireland, the HND is a BTEC qualification awarded by Edexcel. In Scotland, a Higher National is awarded by the Scottish Qualifications Authority (SQA). The attainment level is roughly equivalent to second year of university, a Diploma of Higher Education, but in some cases may be marginally below that of a bachelor's degree. An HND takes two years of full-time study, or one year full-time following successful completion of a Higher National Certificate; part-time study takes longer. Forrás:http:/en.wikipedia.org/ wiki/Higher_National_Diploma 
az információáramlás a szervezeti egységek között. Az egy karú szervezeti forma is a rugalmasságot és a konfliktusmentességet biztosítja ebből a szempontból.

Az egyetemi finanszírozásban a külföldi hallgatóktól származó bevétel még nem játszik jelentős szerepet, de nem is ez az elsődleges elvárás. Az éves költségvetés 3,5 milliárd forint, amelyből 800 millió forint az állami támogatás. A 100 millió forintra becsült bevétel nagyjából összhangban van a feladatra fordított kiadásokkal. Például a tanárok óraszámában az angol nyelvű képzés 1,5-ös szorzóval szerepel. Az oktatókat ösztönzik arra, hogy vegyenek részt külföldi konferenciákon és erre külső forrásokból pályázzanak. (A felső vezetés is Campus Hungary támogatással volt külföldön.) A hallgatók útiköltség támogatásért a DF Alapítványhoz is fordulhatnak.

Az oktatási rektorhelyetteshez tartozó Nemzetközi Kapcsolatok Iroda 1 vezetővel és 3 alkalmazottal látja el a nemzetközi feladatokat. A tanulmányi hivatalban és a kollégiumban további 1-1 fö, valamint 3 demonstrátor hallgató munkája jelenti még az adminisztratív munkaerőt. Tanári oldalról 15 fő érintett még a szervezési munkában. A rugalmas szervezeti forma biztosítja, hogy szükség esetén nagyobb humán erőforrást vonjanak be a nemzetközi tevékenységbe. Szükség van a szakmai, nyelvi továbbképzésükre.

\subsection{Nyugat-magyarországi Egyetem}

A Nyugat-magyarországi Egyetem 10 kara a Nyugat-Dunántúl régió teljes területére kiterjed, így például Győrött, a régió másik, meghatározó egyetemének, a Széchenyi István Egyetemnek a székhelyén található a legnagyobb hallgatói létszámot (2011-ben 2798 főt) felvonultató Apáczai Csere János Kar (AK). Egyidejűleg a Közép-Dunántúl régióhoz tartozó Székesfehérváron működik a legkisebb létszámú Geoinformatikai Kar (GEO). Ez a területi szétaprózottság tulajdonképpen két nagyobb intézményi öszszevonás eredményeként jött létre 2000-ben és 2008-ban, amikor még 16000 körüli hallgatói létszámról beszélhettünk. Az újonnan felvett hallgatók száma tavaly 30\%-kal, idén pedig nagy valószínűséggel további 20\%-kal fog csökkenni, és a teljes létszám 11000 körül várható. Az egyetem (PPP beruházások miatt is) megrendült finanszírozási helyzetén a kormány struktúra átalakító alapjából megszerzett 1,5 milliárd forintért az egyetem vállalta, hogy „oldja” a korábbi erős kari struktúrát, ami részben a párhuzamos képzések felszámolását jelenti. (A 2012-es év 7,3 milliárdos állami támogatása 2013-ban 5,1 milliárdra csökkent, és az így keletkezett hiányt sikerült részben betömni a külön forrásból.)

Az 5 városban székelő 10 kar (Sopron 4 kar, Szombathely 3 kar, Győr, Mosonmagyaróvár, Székesfehérvár 1-1 kar) közül, a hallgatói mobilitást illetően, a történelmileg legpatinásabb Mezőgazdaság- és Élelmiszertudományi Kar (MÉK) tekinthető a leginkább nemzetközinek ${ }^{11}$ (10. táblázat). Jóllehet idegen nyelven meghirdetett szakkal nem rendelkeznek, de a külföldi hallgatók 6,9\%-os arányával magasan vezetnek, hisz az egyetemi átlag csak $1,11 \%$. Ha a külföldi hallgatók nemzeti megoszlását tekintjük, akkor a szlovákiai (döntően magyar anyanyelvü) hallgatók vezetik a rangsort, több mint $60 \%$-kal. Románia áll a második helyen, és csak ezután következnek ,igazi” külföldi hallgatók Németországból és Törökországból. Az elkövetkező tanévben várhatóan Kínából és Brazíliából 8 illetve 7 hallgató kezdheti meg a tanulmányait, akik láthatóan színesítik majd a hallgatói mezőnyt.

11 A Pozsonytól 30, Bécstől 60 kilométerre található, 30000 lélekszámú kisváros, Mosonmagyaróvár büszke arra, hogy ott alakult meg Európában az első agráregyetem, 1818-ban. (Ezt ugyan vitatja a keszthelyi Georgikon, amely korábban jött létre, de középfokú intézményként, hangzik az itteni érvelés.) Történelmi érdekesség, hogy Ausztria legnagyobb (egyetlen) agráregyeteme az Universitaet für Bodenkultur (BOKU) 1872-ben, azután jött létre, hogy Mosonmagyaróváron előzőleg a képzés nyelve németről magyarra változott és emiatt sok tanár állás nélkül maradt.

12 Ez az IFT-ben közölt arány alacsonyabb a más forrásokban (Berács et al. 2013) fellelhető 2,3\%-nál, aminek számbavételi okai lehetnek, amire most nem térünk ki. 
10. táblázat: A Nyugat-magyarországi Egyetem nemzetközi mobilitását jellemzö fó adatok szervezeti egységek szerint (2010/2011)

\begin{tabular}{|c|c|c|c|c|c|c|c|c|c|c|}
\hline Jellemzők & $\mathrm{AK}$ & BPK & BTK & EMK & FMK & GEO & KTK & MÉK & MNSK & TTK \\
\hline $\begin{array}{l}\text { Külföldi } \\
\text { hallgatók/ } \\
\text { összes hallgató }\end{array}$ & $\begin{array}{l}6 / \\
2798\end{array}$ & $\begin{array}{l}11 / \\
1093\end{array}$ & $\begin{array}{l}27 / \\
1192\end{array}$ & $\begin{array}{l}0 / \\
965\end{array}$ & $\begin{array}{l}4 / \\
942\end{array}$ & $\begin{array}{l}8 / \\
480\end{array}$ & $\begin{array}{l}9 / \\
1258\end{array}$ & $\begin{array}{l}57 / \\
828\end{array}$ & $\begin{array}{l}9 / \\
1138\end{array}$ & $\begin{array}{l}5 / \\
1538\end{array}$ \\
\hline $\begin{array}{l}\text { Külföldi } \\
\text { részképzésben } \\
\text { részt vevő } \\
\text { hallgatók } \\
\text { aránya }(\%)\end{array}$ & 1,32 & 0,82 & 1,43 & 1,87 & 1,38 & 1,88 & 0,48 & 3,02 & 0,53 & 0,13 \\
\hline $\begin{array}{l}\text { Kiutazó } \\
\text { alkalmazot- } \\
\text { tak/ összes } \\
\text { alkalmazott }\end{array}$ & $\begin{array}{l}6 / \\
151\end{array}$ & $\begin{array}{l}12 / \\
74\end{array}$ & $\begin{array}{l}9 / \\
105\end{array}$ & $\begin{array}{l}2 / \\
164\end{array}$ & $\begin{array}{l}11 / \\
140\end{array}$ & $\begin{array}{l}5 / \\
42\end{array}$ & $\begin{array}{l}3 / \\
97\end{array}$ & $\begin{array}{l}2 / \\
63\end{array}$ & $\begin{array}{l}22 / \\
79\end{array}$ & $\begin{array}{l}4 / \\
84\end{array}$ \\
\hline $\begin{array}{l}\text { Idegen nyel- } \\
\text { ven meghir- } \\
\text { detett szakok } \\
\text { száma }\end{array}$ & 0 & 0 & 0 & 0 & 1 & 0 & 1 & $\mathbf{0}$ & 0 & 0 \\
\hline $\begin{array}{l}\text { Joint degree } \\
\text { jellegű, } \\
\text { közös képzési } \\
\text { együttműkö- } \\
\text { dések száma }\end{array}$ & 0 & 0 & 0 & 0 & $\mathbf{0}$ & 0 & 1 & $\mathbf{0}$ & 0 & 0 \\
\hline $\begin{array}{l}\text { Nemzetközi } \\
\text { intézményi } \\
\text { partner- } \\
\text { kapcsolatok } \\
\text { száma }\end{array}$ & 41 & 36 & 54 & 35 & 34 & 20 & 17 & 58 & 26 & 13 \\
\hline
\end{tabular}

Forrás: www.femip.hu Intézményfejlesztési tervek TABL_17 és TABL_27

Külföldi részképzésen is a Mezőgazdaság- és Élelmiszertudományi Kar hallgatói vesznek részt a legnagyobb arányban, 3,02\%-kal, míg az egyetemi átlag 1,16\%. A legkisebb érdeklődést a Természettudományi és Műszaki Kar (TTK) hallgatói mutatják, ahol ez az arány csak 0,13\%. A jövő szempontjából ígéretes, hogy minden kar rendelkezik nemzetközi intézményi kapcsolatokkal, valamint a 999 alkalmazottból (oktató és nem oktatói státuszban dolgozó személyzetből) 76 fö, azaz 7,6\% vett részt külföldi mobilitásban. Összességében azonban az mondható el, hogy a külföldi hallgató ide vonzása még nem tartozik a 
legfontosabb prioritások közé, és a nagyfokú kari önállóság, területi elkülönülés miatt csak halvány jelei látszanak annak, hogy ez egyetemi szinten meg fog változni. Nincsenek olyan kiemelt nemzetközi mutatószámok, amelyek elérése mozgósító erővel bírna.

Az idegen nyelven meghirdetetett mindhárom szak Sopronban található. A Faipari Mérnöki Kar (FMK) rendelkezik angol nyelvü alapképzéssel. A brazil program keretében Sopront választó mind a 7 diák az Erdőmérnöki Karon (EMK) fog tanulni, ami lökést adhat egy teljes szak angol nyelven való kifejlesztésére. Valószínűleg nem véletlen, hogy a Közgazdaságtudományi Kar (KTK) jár az élen két szak, egy német (Betriebswirtschaftslehre und Management 2007-től) és egy angol nyelvű alapszak meghirdetésével. A nemzetközi gazdaság és menedzsment mester szakon is kínálnak egy német nyelvű modult. A doktori programot német és angol nyelven is fel lehet venni.

Az egyetlen kettős diplomát (double degree) nyújtó programot is a Közgazdaságtudományi Kar hirdeti meg $^{13}$ a Seinäjoki University of Applied Sciences, Finland egyetemmel közösen. Ebben egy évi külföldi tanulmány után lehet megkapni a másik egyetem diplomáját is. A közös program kialakulásához nagyrészt a Sopron és Seinäjoki testvérvárosi kapcsolata vezetett. További stratégiai partneri kapcsolat alakult ki az alabamai Auborg Egyetemmel, valamint a Nyitrai Egyetemmel.

A keleti nyitás érdekében 2009-ben egy kinai ügynökkel kötöttek szerződést (mindezidáig az egyetlen ügynöki szerződés az egyetemen), aki vállalta, hogy a magyar nyelvű programra hoz kínai diákokat. A 2012/13-as tanévben sikerült 15 kínai diákkal elindítani az 1 éves előkészítő, magyar nyelvtanulási programot. Közülük 8 fő adta be a jelentkezését valamelyik szakra. Jelenleg az Oktatási Hivatal állásfoglalását várják a felvételi eljárást illetően. A gondot a magyar nyelvű program okozza, amelyre a normál felvételi rendszert kellene követni, nem az egyetemi hatáskörbe tartozót, mint az angol nyelvű programnál. Emiatt kezdték tanulmányozni az iskolai végzettségeket tanúsító oklevelek elismerését a két ország között. ${ }^{14}$

Az intézményi folyamatok, az információáramlás a központi adminisztráció korlátozott száma miatt kevésbé centralizált. A tudományos és nemzetközi rektorhelyettest két főállású munkatárs segíti. A karokon is a három dékánhelyettes modellt valósították meg, akik közül egy fő a tudományos és nemzetközi ügyeket vitte. A költségmegtakarítás miatt ezt a modellt fokozatosan felváltja a két dékánhelyettes modell, amikor a nemzetközi ügy a dékánhoz, vagy az egyik helyetteshez kerül. A jelenlegi intenzitás mellett ez az út követhető, az informális kapcsolatok konfliktusmentesek, de a trend mindenképpen kedvezőtlen, ha a nemzetközi mobilitásban fordulatot kívánna elérni az egyetem.

A finanszírozási kérdések nem állnak a középpontban. Az Erasmus program keretében évi 350000 euro körüli támogatással számolnak, de további bevételi adatok a külföldi hallgatóktól egyetemi szinten nem ismertek. A Campus Hungary programban részt vesznek. Csak néhány kar képes a külföldre utazó hallgatóknak kiegészítő, szimbolikus támogatást nyújtani.

A minőségbiztositást a szakokra vonatkozóan a MAB garantálja. Az egyetem, oktatóinak nemzetközi publikációi alapján, a magyar egyetemek között a 12. helyet foglalja el, jóllehet a karok fele főiskolai

13 A kar angol nyelvű honlapján a július 23-i kereséskor még a 2012 októberében frissített, 2012/2013-as tanév adatai szerepeltek. Az őszi félévben 10, míg a tavaszi félévben 9 angol nyelven hirdetett tárgyra lehetett jelentkezni. A közös diplomáról szóló honlap nehezen felfedezhető, ezért nem mindenki számára hozzáférhető az információ. A német nyelvű honlap mindhárom képzési szintről részletes információkat tartalmaz. Arról viszont, hogy hányan vannak a programban, illetve kik végezték el, semmilyen nyelven sem találunk adatot. A kar újonnan megválasztott dékánja Fábián Attila, a Kisalföldnek adott interjúban az első feladatai között a nemzetközi tevékenységet emelte ki. „Tervem, hogy a környező országok felsőoktatási intézményeinek hálózattá való alakításával még hatékonyabbá és szorosabbá tegyük az együttműködést. E témakörbe tartozik még, hogy a kar német és angol nyelvű oktatására is nagyobb hangsúlyt fektessünk. Ez nemcsak hazai diákjaink nyelvtudásának tökéletesítését, hanem a hozzánk érkező külföldi hallgatók tanulását, a mobilitás fokozását is szolgálja.” (Kisalföld, 2013. július 11.)

14 A 176/1998. (X.30.) Korm. rendelet a Magyar Köztársaság Kormánya és a Kínai Népköztársaság Kormánya között az iskolai végzettségeket és tudományos fokozatokat tanúsító okiratok kölcsönös elismeréséről szóló Egyezmény kihirdetéséről. Ez a dokumentum kölcsönösen elismeri a küldő állam által elismert okleveleket a fogadó államban is. 
háttérrel rendelkezett. A ki- és beutazó diákok, alkalmazottak visszajelzéseit csak részlegesen értékelik, elsősorban a külső (pl. Erasmus) elvárásoknak megfelelve.

Az oktatásszervezésben a külföldi hallgatók kezelése elkülönülten folyik. Az alacsony létszám, és a földrajzi elkülönültség miatt nincs is túl nagy igény a folyamatok központosítására. Egységes egyetemi katalógussal nem rendelkeznek. (Ebbe az irányba vezet az MRK brazíliai programja, valamint a Campus Hungary idegen nyelvü kurzusok leírásainak bekérése.)

A humán erőforrás fejlesztése szükséges és el is indult mind az Erasmus személyzeti mobilitás, mind a nyelvi továbbképzés terén. Ugyancsak pozitív fogadtatásra talált a szeptemberi EAIE konferencián és vásáron való részvétel Campus Hungary által történő támogatása. A nyelvtanári diplomával rendelkező munkatársak számára a TKA által hirdetett nemzetközi marketing és kultúraközi kommunikáció továbbképzések is népszerűek. Becslés alapján a nemzetközi ügyekkel foglalkozó adminisztratív munkaerő teljes idős egyenértéke (FTE) 11 fö, míg az oktatók ilyen irányú tevékenysége 20 fővel egyenértékű.

\subsection{Széchenyi István Egyetem}

A 2000-ben megalakult Széchenyi István Egyetem egy ambiciózus főiskola és város együttműködésének a terméke, amely arra a történelmi tényre épít, hogy Győr már a 18. századtól egyetemi város volt és ezt a hagyományt a dinamikusan fejlődő iparral rendelkező, gazdag kulturális háttért felmutató város folytatni kívánja. A szándékot tett követte és 1990-ben, a rendszerváltás után 8 alapító, az akkori főiskola, a város, a Gazdasági és Közlekedési Minisztérium, a MÁV Zrt, a Magyar Posta Zrt, a Rába Járműipari Holding Nyrt, Antenna Hungária Zrt, Magyar Telekom Nyrt 6 millió forinttal létrehozta az Universitas Győr Alapítványt. Az alapítvány honlapján szereplő történeti leírás ${ }^{15}$, valamint a 2012-es közhasznúsági jelentés tanulmányozása hasznos lehet, abból a szempontból is, hogy egy ilyen alapítványt miként lehet működtetni, illetve felhasználni a nemzetközi célok érdekében.

Az Alapítvány vagyona időközben 128 millió forintra emelkedett, ami azért következett be, mert az évente befolyt támogatási összegeket nem osztották ki. Így például 2012-ben az előző évi 55 millió forintos támogatással szemben csak 33 millió forintot osztottak ki, de közben 6 millió forinttal emelték az alapítványi vagyont. A 2010-2012 közötti időszakban a nemzetközi (TÁMOP) támogatásból befolyt 37 millió forintot az egyetem oktatói számára „nemzetközi vendégoktatói ösztöndíjak” formájában nyújtották. Ennek keretében egy féléven keresztül, a fizetést megtartva, 3 millió forintból gazdálkodva, lehetett neves külföldi egyetemen kutatni, kapcsolatokat építeni, angol vagy német nyelvű oktatásra felkészülni ${ }^{16}$.

Ezek az ösztöndíjak is hozzájárultak ahhoz, hogy a Széchenyi Egyetemen a legmagasabb a kiutazó oktatók és személyzet aránya (88\%) a teljes alkalmazotti létszámhoz képest. (11. táblázat). Leginkább azonban azért magas ez az arány, mert az egyetem központilag minden munkatársának a külföldi útját számon tartja, függetlenül attól, hogy milyen forrásból utazik. A „külföldi kiutazási szabályzat” előírja,

15 „Mi alapítók, attól az óhajtól vezérelve, hogy a Széchenyi István Főiskola egyetemi rangra emelkedjék, ezáltal Győr városa az egyetemi városok sorába lépjen, nemkülönben, hogy a megalakult egyetem működését és fejlődését ezáltal támogassuk, UNIVERSITASGYŐR névvel Alapítványt hoztunk létre....» Az alapító dokumentum 1990. június 6-án született. Az elmúlt 18 évben 770 millió Fttal gazdálkodhatott az Alapítvány. Különösen jelentős volt Győr városának 270 millió Ft-os támogatása, és az a 90 millió Ft, amit a céljainkkal egyetértő adózó állampolgárok ajánlottak fel személyi jövedelemadójuk 1\%-ából. Ezen túlmenően kiemelkednek az Alapítvány programjaihoz kapcsolódó céltámogatások, amelyeket egyrészt győri cégek, másrészt országos hatáskörű nagyvállalatok ajánlottak fel összesen több mint 100 millió Ft összegben.

16 „Az alapítvány céljának eléréséhez a 2012. évben is kívánatosnak tartotta a Széchenyi István Egyetem (SZE) oktatóinak támogatását a világ legértékesebb felsőoktatási tapasztalatainak megismeréséhez, a legújabb tudományos eredmények átvételéhez és alkotó továbbfejlesztéséhez, ezzel is biztosítva a nemzetközi kapcsolatok kiépítését, új szakmai kapcsolatok, technológiák meghonosítását, az idegen nyelvű oktatási tevékenység fejlesztését, a tudományos fokozatok megszerzését. Kiemelt fontosságúnak tekintette a SZE hallgatók szakmai, tanulmányi és tudományos tevékenységének támogatását és elismerését - kiemelve a tudományos diákköri szervezet és a szakkollégiumok eredményes működésének támogatását.” UNIVERSITAS-GYŐR Alapítvány 2012. évi közhasznúsági jelentése. 
hogy minden alkalmazottnak utazási határozattal kell rendelkeznie, mielőtt külföldre megy, amit a tanszékvezető és/vagy a dékán aláírásával a Tudásmenedzsment és Nemzetközi Kapcsolatok Központhoz kell eljuttatni, ahol a rektorhoz közvetlenül tartozó igazgató aláírásával válik érvényessé. A korábban független Nemzetközi Iroda, International Project Center (IPC) névre hallgatott és a honlapján (http:// ipc.sze.hu) megtalálható minden információ az utazással, elszámolással és a beszámoló elkészítésével kapcsolatban. Ez utóbbit külön kiemeljük, mert kevés helyen található ilyen szisztematikus rendszer.

A Széchenyi Egyetemen 11000 körül alakul a hallgatók száma (12000 volt a csúcs), ami 2013 szeptemberétől kissé csökkenni fog, mert az újonnan felvettek száma, az országos átlaggal megegyezően, 10\%-kal csökkent. Stabil pénzügyi gazdálkodás jellemzi az intézményt, a 7-8 milliárd forint közötti éves költségvetés fele származik állami támogatásból. Az elmúlt években jelentős infrastrukturális fejlesztést hajtottak végre (nem PPP konstrukcióban), amelyek csökkentették a zsúfoltságot, a nemzetközi igényeknek inkább megfelelő fogadó tereket, laborokat, inkubációs oktatási központokat és egyéb új funkcionális tereket alakítottak ki. Így például rendelkeznek aulával mint az egyetemi lét egyik szimbolikus létesítményével. Az újonnan alakult doktori iskolák szintén méltó elhelyezést kaptak.

11. táblázat: A Széchenyi István Egyetem nemzetközi mobilitását jellemző fö adatok szervezeti egységek szerint (2010/2011)

\begin{tabular}{|c|c|c|c|c|c|c|}
\hline Jellemzők & $\begin{array}{l}\text { Müszaki } \\
\text { Tud. Kar }\end{array}$ & $\begin{array}{l}\text { Kautz } \\
\text { Gyula } \\
\text { Gazda- } \\
\text { ságtu- } \\
\text { dományi } \\
\text { Kar }\end{array}$ & $\begin{array}{l}\text { Deák } \\
\text { Ferenc } \\
\text { Állam- } \\
\text { és Jog } \\
\text { Tud Kar }\end{array}$ & $\begin{array}{l}\text { Petz } \\
\text { Lajos } \\
\text { Egész- } \\
\text { ségtudo- } \\
\text { mányi } \\
\text { és Szoc. } \\
\text { Int. }\end{array}$ & \begin{tabular}{|l} 
VT \\
Zene- \\
tudo- \\
mányi \\
Intézet
\end{tabular} & Együtt \\
\hline Külföldi hallgatók aránya (\%) & 4 & 7 & 5 & 4 & 3 & 5 \\
\hline $\begin{array}{l}\text { Külföldi részképzésben részt } \\
\text { vevő hallgatók aránya (\%) }\end{array}$ & 0,4 & 0,8 & 1,0 & 0,0 & 1,4 & 0,5 \\
\hline $\begin{array}{l}\text { Kiutazó alkalmazottak aránya } \\
(\%)\end{array}$ & 100 & 181 & 14 & 17 & 13 & 88 \\
\hline $\begin{array}{l}\text { Idegen nyelven meghirdetett } \\
\text { szakok száma }\end{array}$ & 1 & 1 & 0 & 0 & 0 & 2 \\
\hline $\begin{array}{l}\text { Joint degree jellegü, közös } \\
\text { képzési együttműködések } \\
\text { száma }\end{array}$ & 0 & 0 & 0 & 0 & 0 & 0 \\
\hline $\begin{array}{l}\text { Nemzetközi intézményi part- } \\
\text { nerkapcsolatok száma }\end{array}$ & 56 & 9 & 1 & 0 & 0 & 66 \\
\hline
\end{tabular}

Forrás: www.femip.hu Intézményfejlesztési tervek TABL_17 és TABL_27 
A felső vezetés elköteleződése a nemzetközi orientációra a küldetésnyilatkozatban (követve az Erasmus Charter célkitűzéseit is) tetten érhető, de eddig sokkal inkább a kutatási vonalra összpontosított, mintsem a mobilitásra. A három karból és két intézetből álló egyetem az országos átlaghoz közeli 5\%-os arányt mutat fel a külföldi hallgatók arányában (11. táblázat), de ez megtévesztő, mert a külföldiek közel 90\%-a határon túli (elsősorban szlovákiai) magyar, akik csak a statisztikákban külföldiek. Az Erasmus, CEEPUS és néhány kétoldalú csere keretében érkező hallgatók aránya $1 \%$ alatt van, ami alig észrevehető. A külföldi részképzésben részt vevő hallgatók aránya $0,5 \%$, amelyre vonatkozóan nincsenek stratégiai irányszámok 2020-ig. Miként arra sem, hogy el akarja-e érni az egyetem a kormányzati célt, a végzettek 20\%-ának külföldi tapasztalatszerzését.

A Műszaki Tudományi Kar németül és a Kautz Gyula Gazdaságtudományi Kar angolul hirdetett meg egy-egy mesterszakot, amelyen csak elvétve fordul elő külföldi hallgató, és a szak nem is tud mindig elindulni magyar hallgatók hiányában. Az egyetem nem látta értelmét alapszinten idegen nyelvű programok meghirdetésének, feltételezve, hogy a nemzetközi mozgásban a nagyobb, híresebb egyetemek viszik el a hallgatókat, akikkel nem akarnak versenyezni. A műszaki területen az Audival való együttműködés adhat speciális vonzerőt a szaknak, amit távlatilag angolul is kifejlesztenének. Ezen gondolatmenet alapján inkább a $\mathrm{PhD}$ program angol nyelvü változata szerepel a tervekben. A fő akadályt azonban abban látják, hogy az idősebb generáció nyelvileg nincs felkészülve az idegen nyelvű oktatásra. A korábban jelzett ösztöndíjak segítségével 4-5 éven belül lesz olyan tömegü fiatal oktatói gárda, akire támaszkodva áttörést lehet végrehajtani.

A nemzetközi intézményi partnerkapcsolatok száma az IFT-ben alulbecsült, mert döntően az általános, nem európai partnereket tartalmazza. Az IPC portálon részletesen felsorolt 126 Erasmus partner között a legtöbb Németországból és Ausztriából származik. A legerőteljesebb nyomás Törökországból érkezik az intézmények részéről kapcsolatfelvételre, ahol már önmérsékletet kell tanúsítani, mert kevés magyar hallgató jelentkezik ebbe a relációba, és nem akarják egyoldalúvá tenni az együttműködést.

Látványosan 155 idegen nyelvü tárgyat találunk a honlapon a külföldi és magyar hallgatók számára. Ennek csak egy része indul el a jelentkezések alacsony száma miatt. A magyar hallgatók tanulmányaik végén mennek külföldre, ezért viszonylag kevés tárgyat számítanak be a diplomába, de a Diploma Supplementben azokat is megjelenítik.

Jelenleg a hallgatók kb. 15\%-a nem tudja megkapni a diplomát a nyelvvizsga hiánya miatt. Ezen változtatni szeretnének, és az Idegen Nyelvü Oktatási Központ rektor közvetlen hatáskörbe kerül. Az oktatók kiscsoportos képzésére is nagyobb hangsúlyt helyeznek.

\subsection{Szegedi Tudományegyetem}

„Százhuszonnegyedik helyezés az európai egyetemek tudományos ranglistáján (ARWU), az Európai Unió 7. K+F Keretprogramjában 21 nyertes pályázat, több mint ezer külföldi hallgató, 61 testvéregyetem - ez a néhány adat jól mutatja, hogy a Szegedi Tudományegyetem egyike hazánk vezető felsőoktatási intézményeinek." Így kezdődik az SZTE bemutatkozása a honlapon. (letöltve: 2013. július 1.) Ez a néhány sor még visszafogottabb, mint a valóság, hiszen a jelenlegi 27000 egyetemi hallgatóból 2200 a diplomakredites és 400 körül van a szemeszterkredites külföldi hallgató.

Az IFT-ben található mobilitási adatok (12. táblázat) 12 karra vonatkoznak, és helyenként meglehetősen hiányosak. Joint degree jellegű közös képzést csak az Állam- és Jogtudományi Kar (ÁJTK) tüntetett fel, és öt karnál nem szerepel nemzetközi intézményi partnerkapcsolat, ami szintén csak kitöltési probléma lehetett. Az első sorban a külföldi hallgatók arányánál minden bizonnyal csak a résztanulmányokat folytató hallgatókat vették számba, amelyek aránya 0 és $1 \%$ között szóródott, átlagosan 0,59\% volt. 
A 2011/12-es tanév 2282 külföldi diplomakredites hallgatójából 1111 fö az orvosi karokon tanult (akiknek több mint fele Németországból, Izraelből és Iránból érkezett), és 850 fö, döntően magyar anyanyelvű hallgató pedig Szerbiából érkezett. A küldő országok között ötödik helyen Románia szerepel, ahonnan több mint 100 fó érkezett.

Az idegen nyelven meghirdetett szakok számában a Bölcsésztudományi Kar (BTK) vezeti a rangsort 20 szakkal, akit az Állam- és Jogtudományi Kar (ÁJTK), majd az Általános Orvosi Kar (ÁOK) követ. Ilyen környezetben is található 5 kar a 12-böl, ahol még nem fejlesztettek ki teljes szakot idegen nyelven, ahol a vendéghallgatók egyéni kurzuskínálatból választanak, ahol ennek következtében is alacsonyabb a ki- és beutazó hallgatók száma. Ugyanez nem mondható el a kiutazó alkalmazottakról, hiszen ott a Mezőgazdasági Kar (MGK) vezet 21\%-os aránnyal, miközben a hallgatói mobilitásban nem jeleskednek.

12. táblázat: A Szegedi Tudományegyetem nemzetközi mobilitását jellemzö fó adatok szervezeti egységek szerint (2010/2011)

\begin{tabular}{|c|c|c|c|c|c|c|c|c|c|c|c|c|}
\hline Jellemzők & $\begin{array}{l}\text { 己. } \\
\text { 泾 }\end{array}$ & 完 & 㖼 & 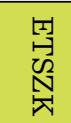 & 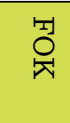 & 里 & 胥 & 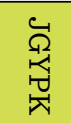 & 泰 & 穴 & 曷 & 爸 \\
\hline $\begin{array}{l}\text { Külföldi } \\
\text { hallgatók } \\
\text { aránya (\%) }\end{array}$ & 0,35 & 0,88 & 1,00 & 0,53 & 0,66 & 0,66 & 0,47 & 0,64 & 0 & 0,58 & 0,33 & 0 \\
\hline $\begin{array}{l}\text { Külföldi } \\
\text { részkép- } \\
\text { zésben } \\
\text { részt vevő } \\
\text { hallgatók } \\
\text { aránya (\%) }\end{array}$ & 1,08 & 0,88 & 1,55 & 0,18 & 1,99 & 1,61 & 0,47 & 0,48 & 0 & 0,19 & 0,73 & 1,25 \\
\hline $\begin{array}{l}\text { Kiutazó al- } \\
\text { kalmazot- } \\
\text { tak aránya } \\
(\%)\end{array}$ & 1,10 & 0,22 & 11,28 & 1,03 & 0 & 10,19 & 0,60 & 9,41 & 20,93 & 13,79 & 1,74 & 0 \\
\hline $\begin{array}{l}\text { Idegen } \\
\text { nyelven } \\
\text { meghirde- } \\
\text { tett szakok } \\
\text { száma }\end{array}$ & 6 & 4 & 20 & 0 & 1 & 0 & 1 & 0 & 0 & 0 & 3 & 3 \\
\hline
\end{tabular}




\begin{tabular}{|l|l|l|l|l|l|l|l|l|l|l|l|l|}
\hline $\begin{array}{l}\text { Joint } \\
\text { degree jel- } \\
\text { legü, közös } \\
\text { képzési } \\
\text { együttmü- } \\
\text { ködések } \\
\text { száma }\end{array}$ & 1 & n.a & n.a & n.a & n.a & n.a & n.a & n.a & n.a & n.a & n.a & n.a \\
\hline $\begin{array}{l}\text { Nem- } \\
\text { zetközi } \\
\text { intézményi } \\
\text { partner- } \\
\text { kapcsola- } \\
\text { tok száma }\end{array}$ & n.a & $\mathbf{5}$ & n.a & 12 & 2 & n.a & n.a & 1 & 57 & 31 & 438 & n.a \\
\hline
\end{tabular}

Forrás: www.femip.hu Intézményfejlesztési tervek TABL_17 és TABL_27

Az IFT adatok hiányosságai ellenére a Szegedi Tudományegyetem élen jár a nemzetközivé válásban és a különböző mobilitási programokban. ${ }^{17}$ A kezdetektől (1998-tól) részt vesz az Erasmus programban, aminek elismerése a 2006-ban a kormánytól kapott „Európai Minőségi Díj”, illetve hogy 2008 után 2010ben is bekerültek az európai sikertörténeteket felvonultató Erasmus kiadványba. A nemzetközi aspektus markánsan megjelent a kiválósági pályázatban is, amely alapján az ország három kiemelt egyeteme közé sorolták őket. Ennek a forrásából 3 új adminisztratív nemzetközi munkatárs felvételére is sor kerül. A dél-alföldi régió iránti nemzetközi elkötelezettséget jelzi, hogy együttműködnek a régióba tartozó Kecskeméti és Szolnoki Főiskolával is.

A vezetöi elköteleződés sok más területen is tetten érhető. Így például az erős francia kapcsolatokat jelzi, hogy három kar is érdekelt a frankofon egyetemek világszövetségének a munkájában. Francia mintára a $P h D$ programban kettős, illetve közös témavezetésre is sor kerül külföldi partnerintézményekkel, amely keretében már kb. 10 doktorandusz kapott diplomát. Az ÁJTK Európai Tanulmányok Központja a francia Lille Grand Ecole intézménnyel közös diplomát ad ki. Sok más hálózat mellett kiemelten kezelik a Fulbright és a DAAD kapcsolatokat. Közvetlenül a rektorhoz rendelve működik az SZTE Konfuciusz Intézet ${ }^{18}$, amely társszervezőként közreműködött 50 szecsuáni árvízkárosult gyermek magyarországi nyári üdültetésében is. Várható, hogy az intézet tevékenységének hatására nőni fog a kínai diákok száma is a Szegedi Tudományegyetemen.

17 Az Erasmus program számon tartja a sikeres történeteket. Ezek között 2008-ban a Szegedi Tudományegyetem bekerült egy előkelő top 10 listába a tanári mobilitás alapján. Egy részletes kritériumlistának kellett megfelelni, mint pl. a tanári mobilitás hatásaként az intézményben szemléletváltozás következett be az egyetem stratégiájában, a mobilitás integráns részévé vált a szakmai programoknak. Érdemes összehasonlítani a kiválasztott 10 egyetem tanári létszám alapján legnagyobb Szegedi Tudományegyetem egyes adatait a második helyen következő Humboldt Egyetem adataival. Zárójelben a Humboldt egyetem adatai. A 2006/2007-es tanév: tanári létszáma 2243 (2162), kétoldalú együttműködések száma 226(185). A 2000-2006-os időszakban: kimenő tanári mobilitás 545(648), bejövő tanári mobilitás 200(340), teljes tanári mobilitás 745(988). Forrás: Mobility creates opportunities, European Success Stories, Erasmus, Lifelong Learning Programme, Education and Culture DG,European Communities, 2008.

18 A szegedi Konfuciusz Intézet 2012 őszén nyitotta meg kapuit a Szegedi Tudományegyetem és a Shanghai Nemzetközi Tanulmányok Egyetem együttműködésével, a Kínai Nyelvoktatási Tanács (Hanban) támogatása mellett. Az Intézetben az érdeklődők szakképzett kínai tanároktól tanulhatják meg a kínai nyelvet. A tanórák a Konfuciusz Intézetben és az Egyetem egyes karainak tantermeiben zajlanak. Az Intézet a nyelvoktatás mellett nagy hangsúlyt fektet a kínai kultúra megismertetésére is: hétről hétre színes és izgalmas programokkal várja az érdeklődőket. www.konfuciuszintezet.u-szeged.hu 
Az Erasmus-Mundus programokban is élen jár az SZTE amit a sikeres „Choremundus” konzorcium ${ }^{19}$ a tánctudás, gyakorlat és hagyomány mesteri programba ültetésével igazol. A Nemzetközi Mobilitási Iroda által kezelt angol nyelvű honlapon részletes információk találhatók a tevékenységükről, illetve a partnerintézmények listája mellett szemléletes térképek is segítik az eligazodást. Ilyen az itt következő 3. ábra, amely az Európán kívüli partnerek helyszíneit mutatja be.

\section{3. ábra: A Szegedi Tudományegyetem Európán kívüli partnereinek helyszínei}

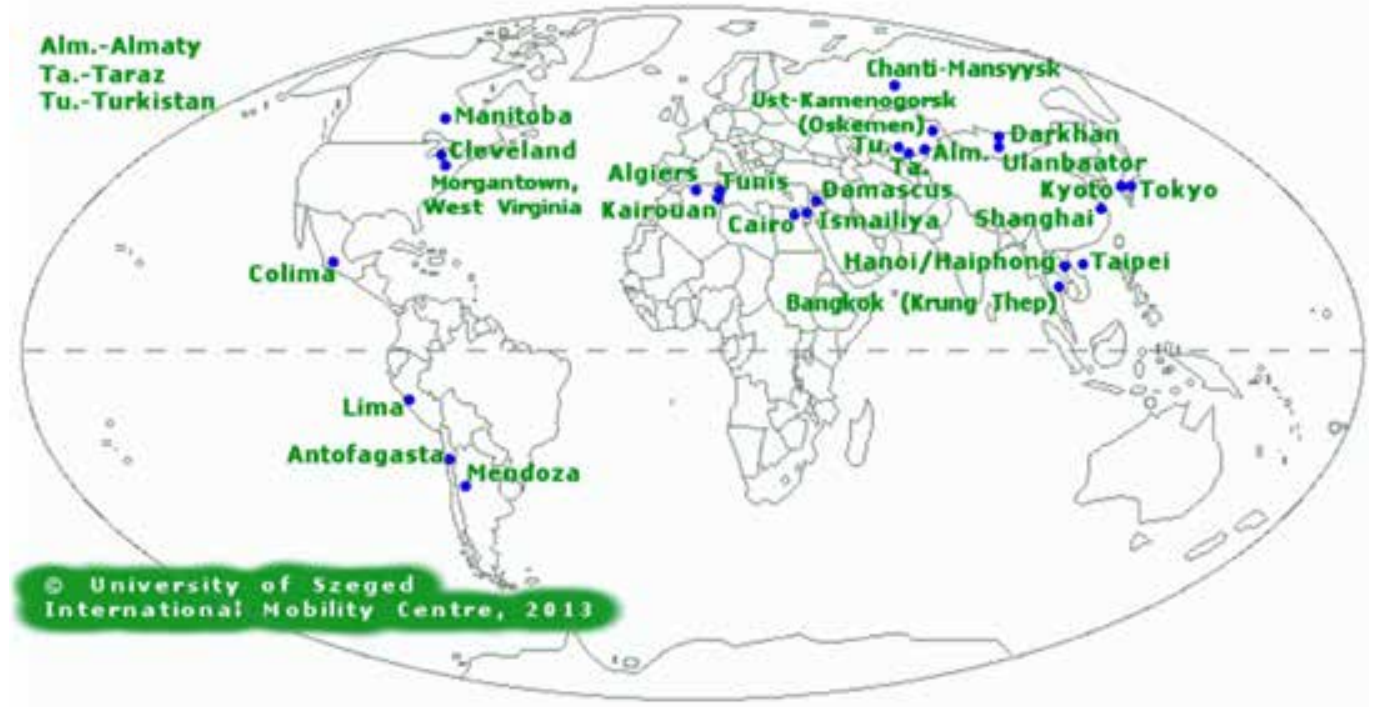

Forrás: www.internationalrelations.u-szeged.hu

A nemzetközi tevékenység szervezetileg a nemzetközi és közkapcsolati rektorhelyetteshez tartozik. Ezen belül a Nemzetközi és Közkapcsolati Igazgatóság foglalkozik általában a nemzetközi kapcsolatokkal, ahol a munkaidőt tekintve 3,5 fó érintett a nemzetközi ügyekben. A Marketing és Kommunikációs Igazgatóságon kb. 2 fővel egyenértékű nemzetközi munka folyik, míg a Nemzetközi Mobilitási Iroda 4 főállású munkatársa mellett 2 hallgató demonstrátor is tevékenykedik. Így mindösszesen jelenleg 10 fo" foglalkozik az egyetemi központban a nemzetközi tevékenységgel, amit a korábban jelzett fejlesztéssel együtt 15 főre kívánnak növelni. Ehhez jönnek a karokon a dékánhelyettesek, illetve a 3 orvosi kart kiszolgáló 3 fős szervezet, amely a stratégiai partnernek számító College International Budapest ügynökségre támaszkodva a fizetős programokra toboroz hallgatókat. A tágan értelmezett nemzetközi mobilitás területén közel 30 fő teljes idős adminisztratív munkaerővel lehet számolni, ha mindenkit számba veszünk az egyéb központi szervezetekben is.

19 Choreomundus - International Master Course in Dance Knowledge, Practice and Heritage has been selected by the European Commission for ERASMUS Mundus International Master Course Funded by the European Commission, Choreomundus will be offered by four internationally renowned academic institutions: Norwegian University of Science and Technology (Trondheim, as cooordinator), Blaise-Pascal University (Clermont-Ferrand), Roheampton University (London) and University of Szeged. www.internationalrelations.u-szeged.hu 
Az intézményi folyamatok szabályozottsága az eredmények tükrében működik ugyan, de különösen a külföldi hallgatók szempontjából további fejlesztésre van szükség az ETR-ben. (Egységes Tanulmányi Rendszer). A finanszírozásban az Erasmus keretek teljes kihasználására törekednek, amely kb. 270 millió forintot jelent a 2013/2014-es tanévben. (Hallgatói mobilitásra 786900 euro, oktatói mobilitásra 119000 euro.) Az egyetemi megtakarítások terhére a szenátusi döntés alapján évente változó összegü hallgatói mobilitási alapot is képeznek (ami legutóbb 12 millió forint volt), amellyel ösztönzik a hallgatói kiutazást. Szegeden is érzékelhető, hogy a hallgatók motiváltsága csökken a nemzetközi útra, nyelvtudás megszerzésére, emiatt az adminisztrációnak a tanárokkal együttműködve nagyobb erőfeszítést kell tenni a meggyőzésre, az eddigi vezető szerep fenntartására. Ezt szolgálja a rendszeres „Ösztöndíjas börze”, amelyre legutóbb 2013. február 19-én került sor. (Szegedi Egyetem Magazin, 2013. februári száma részletesen beszámol a rendezvényről.)

\subsection{Kecskeméti Főiskola}

„Most 835-en örülhetnek, hogy felvételt nyertek a Kecskeméti Főiskolára, tavaly ilyenkor ez a szám 740 volt. Ez $12 \%$-os emelkedést jelent, ami különösen jó eredmény, mert a felvettek száma országosan mintegy $10 \%$-kal csökkent az előző évhez képest, a főiskolák többsége pedig még ennél is nagyobb csökkenést könyvelhet el.”(http://kefoportal.kefo.hu/cimlap, letöltve 2013. július 29.) Az újonnan felvett hallgatók többsége (535 fö) a műszaki karon fog tanulni, őket a tanítóképző (180) követi és hallgatói létszámban a legkisebb a kertészeti képzés (132). A főiskola 2000-ben jött létre két önálló főiskola és egy egyetemi főiskolai kar összevonásából. A város három pontján található képzés kulturálisan is eltérő hagyományokra épül, amit az elmúlt közel másfél évtizedben nem sikerült lényegesen összehangolni. Az integráció vélelmezett pozitív hatásainak a kiaknázása még várat magára. (Egyedül a nyelvi képzést sikerült eddig összevonni és egységesen kezelni.) A 4000 hallgatót 150 oktatóval kiszolgáló, 2,5 milliárd forint költségvetésből gazdálkodó főiskola a nemzetközivé válásnak nagyon a kezdetén tart (13. táblázat).

Mind a beutazó, mind a kiutazó hallgatók száma 1\% körül van, azaz a mindennapokban alig észrevehető. Vezetői szándék van a változtatásra, de a hiányos hallgatói nyelvtudás (a végzettek közel egy negyede nyelvvizsgára vár, hogy átvehesse a diplomáját), az idegen nyelven történő oktatásra képes tanárok alacsony száma, a családi háttér nem kellő motivációja és más tényezők miatt kevés hallgató jelentkezik külföldi útra, illetve kevesen vállalják, hogy idehaza idegen nyelven tanulják a szaktárgyakat. Mindezek mellett a tanárok is kevésbé rugalmasak a külföldön szerzett kreditek elszámolásában, különösen a műszaki területen. Egyelőre nem tervezik, hogy teljes szakot hirdessenek meg idegen nyelven. Az oktatásszervezésnél döntően egyedi módon kezelik a külföldi hallgatókat.

13. táblázat: A Kecskeméti Fơiskola nemzetközi mobilitását jellemző fö adatok szervezeti egységek szerint (2010/2011)

\begin{tabular}{|l|l|l|l|}
\hline & $\begin{array}{l}\text { Gépipari és } \\
\text { Automatizálási Müszaki } \\
\text { F. Kar (GAMF) }\end{array}$ & $\begin{array}{l}\text { Kertészeti F. Kar } \\
\text { (KFK) }\end{array}$ & $\begin{array}{l}\text { Tanítóképző } \\
\text { F. Kar } \\
\text { (TFK) }\end{array}$ \\
\hline Külföldi hallgatók aránya (\%) & 1 & 1 & 1 \\
\hline $\begin{array}{l}\text { Külföldi részképzésben részt } \\
\text { vevő hallgatók aránya (\%) }\end{array}$ & 1 & 1 & 1 \\
\hline
\end{tabular}


Mobilitást akadályozó és ösztönzô intézményi tényezők

\begin{tabular}{|l|l|l|l|}
\hline $\begin{array}{l}\text { Kiutazó alkalmazottak aránya } \\
(\%)\end{array}$ & 16 & 3 & 21 \\
\hline $\begin{array}{l}\text { Idegen nyelven meghirdetett } \\
\text { szakok száma }\end{array}$ & 0 & 0 & 0 \\
\hline $\begin{array}{l}\text { Joint degree jellegü, közös kép- } \\
\text { zési együttműködések száma }\end{array}$ & 0 & 0 & 0 \\
\hline $\begin{array}{l}\text { Nemzetközi intézményi part- } \\
\text { nerkapcsolatok száma }\end{array}$ & 18 & 11 & 10 \\
\hline
\end{tabular}

Forrás: www.femip.hu Intézményfejlesztési tervek TABL_17 és TABL_27

Szervezetileg a rektorhoz rendelten egy fó foglalkozik a külföldi hallgatókkal, a nemzetközi kapcsolatok adminisztratív teendőivel. A karokon oktatói Erasmus felelősök vannak, és az oktatók menedzselik a nemzetközi partneri együttműködéseket is. A gyakorlatorientált képzés megköveteli, hogy sok vállalattal vegyék fel a kapcsolatot, amelyek döntő része a térségbe települt multinacionális cég. Legjelentősebb közöttük a Mercedes, amely a telephely kiválasztásánál stratégiai partnerként kezelte és kezeli most is a főiskolát.

Ennek az együttműködésnek az eredménye az ún. duális szakképzés, amely Németországban általában, de a Mercedes hazájában, Baden-Württembergben különösen népszerü. Ennek a lényege, hogy az érettségizett diákokat a cégek alkalmazzák, és a főiskolán párhuzamosan végzik a tanulmányaikat. Több éves előkészítő munka után 2012 szeptemberében a GAMF Karon 25 hallgató kezdte el a tanulmányait, akik közül 11 fő a Mercedesnél és 14 fő a Knorr Bremse cégnél helyezkedett el. Az 52 hét felosztása a következő: 12 hét tanulás, 8 hét munka, 12 hét tanulás, 16 hét munka, 4 hét szabadság (nyári szünet). A 12 hét alatt, amely szeptemberben és februárban kezdődik, együtt a többi hallgatóval, a 30-30 tanulmányi kredithez szükséges kontaktóraszámot kapnak a hallgatók. Az első év sikeresen zárult, és 2013 szeptemberétől már 30 fö iratkozhat be ebbe a programba, 3 alapszakon és 10 vállalati munkahelyről érkezve. Miután a munkahelyen erős a német nyelv elsajátítására való kényszer, ezért a programban megjelenhet az idegen nyelvű tanítás is, és alapja lehet egy teljes szak idegen nyelven való kifejlesztésének. ${ }^{20}$

„Az első helyen végzett és a legjobb tervezésért és kiváló minőségű kivitelezésért járó díjat is elhozta a Kecskeméti Főiskola GAMF csapata az energiatakarékos jármüvek Valenciában megrendezett versenyéről, amelyre 23 csapat nevezett 5 országból. A csapat itt „vetette be” először a saját fejlesztésű járművezérlő elektronikát. A versenyt, amelyet először hirdettek meg, a valenciai MotoGP versenypályán rendezték meg GreenPrix elnevezéssel. A kecskemétiek eddigi kiemelkedő eredményeik alapján kaptak meghívást." (http://gamf.kefo.hu/cimlap/ismet-nyert-a-gamf-csapat-a-megameterrel-spanyolorszagban) Az ilyen és ehhez hasonló hírek is hozzájárulnak a Főiskola nemzetközi hírnevéhez, valamint alapul szolgálhatnak a nemzetközivé váláshoz.

20 Mint minden ilyen új vállalkozásnak, ennek is személyi feltételei vannak. Ígéretes, hogy a főiskola új rektora, aki 3 éve csatlakozott a Kecskeméti Főiskolához, személyében megtestesíti a gyakorlati és az elméleti orientációt, multinacionális vállalati gyakorlatra támaszkodva. Dolgozott a katonaságnál, a Budapesti Műszaki és Gazdaságtudományi Egyetemen és a Knorr Bremsénél. 


\subsection{Debreceni Egyetem}

A Szegedi Tudományegyetem és az ELTE mellett harmadik intézményként a Debreceni Egyetem nyerte el a pénzügyi forrással is járó „Kiemelt Felsőoktatási Intézmény” (University of Excellence) címet. Ez már jelzi, hogy a konvergencia régióban található legnagyobb vidéki egyetem sok szempontból az országos „legek” csoportjába tartozik. Például a legrégebbi magyarországi, folyamatosan működő egyetem, ${ }^{21}$ miként azt az egyetemről szóló bemutatkozó levélből is megtudhatjuk. Itt van a legtöbb külföldi hallgató, akik száma az elmúlt évtizedben megháromszorozódott.

A nemzetközi egyetem címet joggal magának kiosztó egyetem 30000 hallgatójából a 2012/13-as tanévben 3600 fö jött külföldről, akiknek a kétharmada angol nyelven tanult. Az előzetes kalkuláció szerint 2013 szeptemberében 820 külföldi hallgató kezdi tanulmányait, aminek nagy szerepe van abban, hogy összességében várhatóan nem csökken a hallgatói létszám. A három centrumba szervezve 15 kar tevékenykedik, akik nagy szórást mutatnak a külföldi hallgatók arányát illetően (14/ a. és b. táblázat). A három orvosi kar kiemelkedik a 47, 53 és 19\%-os aránnyal. Őket a Mezőgazdaság-, Élelmiszer-tudományi és Környezetgazdálkodási Kar (MÉK) követi 12\%-kal. A 7,25 \%-ot produkáló Informatikai Kar van még az országos átlag felett. Az ennél kisebb arányt képviselő karok is előkelő helyen vannak a szakterületük szerinti országos rangsorban.

14/a. táblázat: A Debreceni Egyetem nemzetközi mobilitását jellemzőfó adatok szervezeti egységek szerint (2010/2011)

\begin{tabular}{|l|l|l|l|l|l|l|l|l|}
\hline & ÁJK & ÁOK & BTK & EK & FOK & GVK & GYFK & GYTK \\
\hline $\begin{array}{l}\text { Külföldi hallgatók aránya } \\
(\%)\end{array}$ & 0,3 & 47,1 & 3,1 & 2,2 & 52,6 & 2,0 & 0 & 19,4 \\
\hline $\begin{array}{l}\text { Külföldi részképzésben részt } \\
\text { vevő hallgatók aránya (\%) }\end{array}$ & 0,53 & 1,05 & 2,08 & 0,05 & 0,17 & 0,50 & 14,0 & 0,44 \\
\hline $\begin{array}{l}\text { Kiutazó alkalmazottak } \\
\text { aránya (\%) }\end{array}$ & n.a & n.a. & n.a. & n.a. & n.a & n.a & n.a & n.a \\
\hline $\begin{array}{l}\text { Idegen nyelven meghirdetett } \\
\text { szakok száma }\end{array}$ & 0 & 2 & 0 & 0 & 1 & 2 & 0 & 1 \\
\hline
\end{tabular}

21 „A Debreceni Egyetem addig önállóan működő intézmények (újra) egyesítésével és jogutódlásával 2000. január 1-jével alakult meg. Történelmi gyökerei visszanyúlnak a Debreceni Református Kollégium alapításáig (1538), amelynek később kialakult három akadémiai tagozatára alapozva jött létre a Debreceni Magyar Királyi Tudományegyetem az 1912. évi XXXVI. Törvénycikk alapján. Ezzel a négy és fél évszázados, megszakítás nélküli múlttal a Debreceni Egyetem az ország legrégebbi, folyamatosan ugyanabban a városban működő felsőoktatási intézménye. Harmincezret meghaladó hallgatói létszámával, 15 karával és 25 doktori iskolájával a legszélesebb képzési és kutatási kínálatot nyújtja Magyarországon. Az egyetem 1500 oktatójának kétharmada tudományos fokozattal rendelkezik, köztük 30 professzor a Magyar Tudományos Akadémia tagja. Az intézmény kutatási eredményeivel az országos teljesítmény mintegy 14-15\%-át tudhatja magáénak." www.unideb.hu 


\begin{tabular}{|l|l|l|l|l|l|l|l|l|}
\hline $\begin{array}{l}\text { Joint degree jellegü, közös } \\
\text { képzési együttműködések } \\
\text { száma }\end{array}$ & 0 & 0 & 1 & 1 & 0 & 1 & 0 & 1 \\
\hline $\begin{array}{l}\text { Nemzetközi intézményi } \\
\text { partnerkapcsolatok száma }\end{array}$ & 10 & 96 & 138 & 7 & 34 & 85 & 11 & 3 \\
\hline
\end{tabular}

Forrás: www.femip.hu Intézményfejlesztési tervek TABL_17 és TABL_27

14/b. táblázat. A Debreceni Egyetem nemzetközi mobilitását jellemző fó adatok szervezeti egységek szerint (2010/2011)

\begin{tabular}{|l|l|l|l|l|l|l|l|}
\hline Jellemzők & IK & KTK & MK & MÉK & NK & TTK & ZK \\
\hline $\begin{array}{l}\text { Külföldi hallgatók aránya } \\
\text { (\%) }\end{array}$ & 7,3 & 4,6 & 2 & 12 & 5 & 4 & 7 \\
\hline $\begin{array}{l}\text { Külföldi részképzésben részt } \\
\text { vevö hallgatók aránya (\%) }\end{array}$ & 0,37 & 1,2 & 2,0 & 0,5 & 0,6 & 0,06 & 1,23 \\
\hline $\begin{array}{l}\text { Kiutazó alkalmazottak ará- } \\
\text { nya (\%) }\end{array}$ & n.a. & n.a. & n.a. & n.a. & n.a. & n.a. & n.a. \\
\hline $\begin{array}{l}\text { Idegen nyelven meghirdetett } \\
\text { szakok száma }\end{array}$ & 4 & 2 & 1 & 3 & 3 & 4 & 0 \\
\hline $\begin{array}{l}\text { Joint degree jellegü, közös } \\
\text { képzési együttműködések } \\
\text { száma }\end{array}$ & 2 & 0 & 0 & 0 & 0 & 0 & 0 \\
\hline $\begin{array}{l}\text { Nemzetközi intézményi } \\
\text { partnerkapcsolatok száma }\end{array}$ & 30 & 40 & 104 & 60 & 27 & 222 & 18 \\
\hline
\end{tabular}

Forrás: www.femip.hu Intézményfejlesztési tervek TABL_17 és TABL_27

Mi a titka a debreceni sikernek? A vezetői elköteleződést kell megemlíteni elsősorban, amely párosul a város befogadó atmoszférájával. Nagyon fontos tényező a megfelelő szervezeti forma. A 2000-ben született egyetemi integráció, a három tudományterületi centrum együttműködése eredményeként, egységes az Orvos- és Egészségtudományi Centrum (OEC) keretében működő Nemzetközi Oktatási Központot (NOK) hozott létre. Az oktató igazgató által vezetett szervezetben 13 fóállású munkatárs dolgozik. Az angolul International Education Center névre keresztelt szervezet foglalkozik részben a 32 idegen nyelven meghirdetett szak nemzetközi promóciójával, marketingjével is. Itt már érvényesül a gazdaságos méretnagyság és a szinergia. A másik két nagy vidéki egyetemhez képest, itt az egyetem központilag foglalkozik a márkaépítéssel, a nemzetközi ügynöki hálózat fejlesztésével, az országstratégiákkal. Emellett létezik a rektorhoz rendelten is egy Nemzetközi Kapcsolatok osztály 4 fövel.

A honlapon, egy globális térképen minden olyan ügynök és irodával rendelkező képviselő fel van tüntetve, aki szerződéses kapcsolatban áll az egyetemmel. Ezáltal a potenciális hallgatók könnyen kapcsolatba léphetnek velük, és elindulhat a felvételi eljárás. A honlapon külön fülön található a Campus-Korea előkészítő program. A BMC-KOREA (Basic Medical Campus-Korea) a Debreceni Egyetem által elismert oktatási központ, és kizárólagos ügynök a koreai állampolgárok vonatkozásában, amely a DE által akkreditált, 6 hónapos vagy 1 éves előkészítő tanfolyamot biztosít az általános orvosi képzés számára. A ki- 
helyezett tagozatként (branch school) működő szervezetben szerezhető oklevélről az 5.4. melléklet ad részletesebb tájékoztatást.

A nemzetközi hírnév számtalan formában megjelenik, elég, ha csak az elnyert nemzetközi kutatási projekteket vagy díjakat nézzük. A Debreceni Egyetem Orvos- és Egészségtudományi Centruma (DEOEC) 2007-ben felkerült a legdinamikusabban fejlődő kis és közepes vállalkozásokat díjazó „Europe’s 500” lista 224. helyére, a biotechnológia és az egészség kategóriában az egyetlen hazai szervezetként. Ez jelzi, hogy egy egyetemi szervezet működési paraméterei összevethetők az üzleti élet bármilyen vállalkozásaival, árbevétel, termékfejlesztés, innovációs képesség és egyéb kategóriákban is.

Az egyetem 1300 nemzetközi intézményi partnerkapcsolata közül 300 érintett az Erasmus cserében. Az utóbbi időben relatíve kevesebb diák ment ki ennek keretében. Míg a 13 évet átfogó időszakot tekintve a DE az 5. helyen állt az országos rangsorban, 2010-ben már csak a \%. helyen. Érdekes módon a Gyermeknevelési és Felnőttképzési Kar (GYFK) vezeti a kari rangsort a külföldi részképzésben részt vevő hallgatók arányát az összes hallgatóhoz viszonyítva 14\%-kal, miközben ők nem fogadnak külföldi hallgatót (2.9. táblázat).

A CEEPUS program keretében kilenc hálózathoz kapcsolódik az egyetem. Az International Student Exchange Program az Amerikai Egyesült Államok több mint száz egyeteme és más kontinensek egyetemei között szervez hallgatói cserét. A kétoldalú együttműködések közül kiemelkedik a finnországi Jyväskyläi Egyetemmel, a francia Champagne-Ardenne Régióval, az amerikai Indiana Egyetemmel (Bloomington), a japán Hirosaki Egyetemmel, a Chiba Egyetemmel és a Wuhan Egyetemmel kialakított ösztöndíjas cserekapcsolat. A több mint kétezer az Orvos- és Egészségtudományi Centrum angol nyelvű képzéseiben részt vevő hallgatóból legtöbben Izraelből, Iránból, Nigériából, Szaúd-Arábiából, Norvégiából, Svédországból jelentkeznek.

A nemzetközi mobilitáshoz kapcsolódó folyamatok és az információáramlás megfelelően szabályozott. Ennek garanciája az ISO minősítési rendszer. A több mint 80 milliárd forintos költségvetésből 2012-ben 6,8 milliárd forint származott a külföldi hallgatóktól. Ennek 90\%-át az orvosi képzés adta. Ha ezt az összeget a 2013-as 14 milliárdos minisztériumi oktatási támogatáshoz hasonlítjuk, akkor látjuk, hogy nem elhanyagolható összegről van szó. Az elosztást, felhasználást illetően vannak viták a központ és a szervezeti egységek között, de mindig találnak megoldást.

\subsection{Nyíregyházi Főiskola}

A Nyíregyházi Főiskola 2000-ben jött létre a Bessenyei György Tanárképző Főiskola és a Gödöllői Agrártudományi Egyetem - Mezőgazdasági Főiskolai Kar fúziójával. Az idők folyamán további három karral bővült a profil és a 2004/05-ös tanévben érte el csúcspontját, amikor 13800 hallgatót regisztrált. Jelenleg 6500 hallgatója van, de az Intézményfejlesztési Tervben hosszabb távon 5000 hallgatóra számítanak. Ehhez kell a működést, a most még 6 milliárd forint körüli költségvetést is igazítani.

A statisztikákban szereplő 240 külföldi hallgató itt döntően határon túli (kárpátaljai) magyar, így a mindennapi életben a nemzetköziség csak elvétve jelenik meg. Uniós országból 43 fö, nem uniós országból (főleg Ukrajnából) 197 hallgató érkezett a 2012/13-as tanévben. A 4\% körüli külföldi hallgatói arány karonként nagy szórást mutat. Külföldi hallgatótól tandíjas bevétel nincs, idegen nyelven egyik kar sem hirdet szakot (15. táblázat). A Főiskola 10 szabadon választható tárgyat hirdet angolul a bejövő cserehallgatóknak, míg az egyes karok további 20 tárgyat kínálnak, döntően egyedi módon. 6 CEEPUS hálózatban vesznek részt, és 53 Erasmus partner intézménnyel tartják a kapcsolatot.

A bejövő Erasmus hallgatók száma 50-60 fö között alakul, míg évente 30-40 kiutazás történik. Nehézséget okoz a magyar hallgatók toborzása, amin most az könnyít, hogy több erdélyi, magyar nyelven 
is oktató egyetemmel vannak kapcsolatban. Az ide érkező és más nyelvet beszélő hallgatók döntően elkülönülnek, kivéve a gyakorlati jellegü képzéseket, mint a zene, sport, amit együtt is tudnak csinálni, és a tanárok megoldják a kétnyelvű kommunikációt. Néha érdekes párosítások alakulnak ki. Például az elmúlt esztendőben 6- 6 portugál és litván tanár szakos vendéghallgató az Apáczai János Gyakorló Iskolában a magyarul zajló hospitálást ülte végig, és az alapján írtak angol nyelvű beszámolót, egyéni tanári konzultáció segítségével.

15. táblázat: A Nyíregyházi Föiskola nemzetközi mobilitását jellemzófó adatok szervezeti egységek szerint (2010/2011)

\begin{tabular}{|c|c|c|c|c|c|}
\hline Jellemzők & $\begin{array}{l}\text { Bölcsészet- } \\
\text { tudományi } \\
\text { és Müvészeti } \\
\text { Kar }\end{array}$ & $\begin{array}{l}\text { Gazdasági } \\
\text { és Társa- } \\
\text { dalomtudo- } \\
\text { mányi Kar }\end{array}$ & $\begin{array}{l}\text { Müszaki és } \\
\text { Mezőgazda- } \\
\text { sági Kar }\end{array}$ & $\begin{array}{l}\text { Pedagógus- } \\
\text { képző Kar }\end{array}$ & $\begin{array}{l}\text { Természet- } \\
\text { tudományi } \\
\text { és Informa- } \\
\text { tikai Kar }\end{array}$ \\
\hline $\begin{array}{l}\text { Külföldi hallga- } \\
\text { tók aránya (\%) }\end{array}$ & 2,53 & 9,10 & 1,18 & 0,82 & 1,20 \\
\hline $\begin{array}{l}\text { Külföldi részkép- } \\
\text { zésben részt vevő } \\
\text { hallgatók aránya } \\
(\%)\end{array}$ & 1,39 & 0,30 & 1,10 & 0,13 & 0,60 \\
\hline $\begin{array}{l}\text { Kiutazó alkalma- } \\
\text { zottak aránya (\%) }\end{array}$ & 29,50 & & & & \\
\hline $\begin{array}{l}\text { Idegen nyelven } \\
\text { meghirdetett } \\
\text { szakok száma }\end{array}$ & 0 & 0 & 0 & 0 & 0 \\
\hline $\begin{array}{l}\text { Joint degree } \\
\text { jellegü, közös } \\
\text { képzési együtt- } \\
\text { működések } \\
\text { száma }\end{array}$ & 0 & 0 & 0 & 0 & 0 \\
\hline $\begin{array}{l}\text { Nemzetközi } \\
\text { intézményi part- } \\
\text { nerkapcsolatok } \\
\text { száma }\end{array}$ & 5 & 0 & 22 & 3 & 44 \\
\hline
\end{tabular}

Forrás: www.femip.hu Intézményfejlesztési tervek TABL_17 és TABL_27

Szervezetileg a nemzetközi tevékenység központilag jelenik meg a Nemzetközi Kapcsolatok Csoport vezetője és két munkatárs közreműködésével, akik közül egy fő most GYES-en van. Márciusban Erasmus 
napot szerveznek a programok népszerűsítésére. A magyar és angol nyelvű honlapon minden szükséges információ hozzáférhető, amit a ki és beutazó hallgatóknak, tanároknak, adminisztratív alkalmazottaknak tudni kell. Itt érhetők el a szükséges nyomtatványok, elszámolások, beszámolások, kérdőívek. A EURAXESS Hungary Mobilitási Központ honlapja (www.euraxess-hungary.hu) is itt érhető el, amely segíti a ki és beutazó kutatókat 37 országban a beilleszkedésben, álláslehetőség felkutatásában, az Európai Kutatási Térséghez való könnyebb csatlakozásban.

A kiutazó alkalmazottak aránya 29,5\%, növekvő tendenciát mutat. Ebben szerepet játszik, hogy a rövid programok egyre vonzóbbak, de nagyobb áttörést a jelenleginél nagyobb vezetői elköteleződés után várhatunk. Az idegen nyelven való tanításra kevesen vállalkoznak, de ez jelenleg nincs is kellően motiválva, pl. magasabb óraterhelési beszámítással. A Nemzetközi Kapcsolatok Csoport vezetője több évet töltött Angliában, és ezért arra is vállalkozott, hogy azon alkalmazottak számára, akik ezt igényelték, nyelvoktatást tartott.

A hallgatók beszervezése a külföldi útra külön feladatot jelent. A Campus Hungary program kínálata jó, de egyelőre csak a csoportos, rövid idejű programokat tudták igénybe venni. Sajnos a Főiskola nem tud anyagi támogatást, kiegészítést nyújtani a külföldi utakhoz. Nincs nemzetközi költségvetés; ha extra programot szerveznek, akkor úgy kell összevadászni a forrást. Az Erasmus programban 118000 eurós keretük van, míg a CEEPUS-ban 2 millió forint körül költenek évente.

Az oktatásszervezés teljesen el van választva a magyar és a külföldi hallgatók esetében. Ez utóbbiakat a Nemzetközi Csoport tartja nyilván. Bizonyos bölcsész szakokon (történelem, magyar) nem igazán van lehetőség nemzetközi mobilitásra. Ugyanakkor a művészeti képzésben több lehetőség lenne például féléves csomagok összeállítására, amit még nem használnak ki. Van egy 6 egyetemet magába foglaló nemzetközi konzorcium, amit a Liverpool Hope University, egy keresztény, magán egyetem vezet, amely keretében rotációs alapon, minden évben más egyetemen kerül sor egy két hetes intenzív zenei programra. Ennek kétszer már a Nyíregyházi Főiskola adott helyet.

A határon túli magyar képzésre beiratkozott hallgatók száma 2011-ben 179 fő volt az egyetlen külföldi telephelyen, a Beregszászi Főiskolán. Ide és más szomszédos országbeli egyetemekre (pl. Partiumi Keresztény Egyetem) is járnak a főiskola tanárai tanítani.

\subsection{Miskolci Egyetem}

A dicső múlt a Miskolci Egyetemet is körbelengi, hiszen világelső műszaki egyetemi felmenőkkel rendelkezik, miként azt a honlap bevezető oldalán, a 2013 nyarán leköszönő rektor üzenetéből ${ }^{22}$ mindenki megtudhatja. A jelenlegi helyzet viszont nem annyira kiszámítható, mint azt az egyetem oktatói, diákjai szeretnék. Ennek is köszönhető, hogy a Miskolci Egyetem értékeit, sokszínűségét és jövőjét féltő oktatók, hallgatók virrasztottak 2013. június 17-én, hétfőn este 8 órától az Egyetemvárosban. Az elnyúló rektorválasztás folyamata, a kormányzat bizalmatlansága, a rektor személyének a kijelölése a kétfordulós választásban sem növelte az önbizalmat.

Az egyetem hallgatóinak száma 15000 fös maximális létszám után 13000 före csökkent, 13 milliárdos költségvetés mellett. Jelentős fejlesztések valósultak meg, döntő részben PPP konstrukcióban, ami évente kb. 1,5 milliárd forinttal terheli az egyetemet. Ennek a tehernek az enyhítésére kormányzati támogatásra lenne szükség.

22 „A Miskolci Egyetem története több mint 275 évre tekint vissza. A világ első műszaki felsőoktatási intézménye, a Selmecbányai Bányászati Akadémia különleges tudást és értéket képviselt. Öröksége, ereklyéi a mai napig áthatják egyetemünk életét. Meggyőződésem, hogy ebben a fejlődésben a kiszámíthatóság és a stabilitás a legfontosabb szempont, az örökös megújulás képességének alapját hagyományaink, nagy formátumú oktatóink, vezető elődeink munkássága adja.” Prof. Dr. Patkó Gyula rektor, www.uni-miskolc.hu/public 
A külföldi hallgatók aránya jelentősen szóródik a kilenc karon. Legmagasabb, de még országos átlag alatti 4,9\%-kal a Comenius Főiskolai Kar, míg a legalacsonyabb részesedést, 0,72\%-ot, az Állam- és Jogtudományi Kar produkálja (16. táblázat). Ennek oka, hogy 2010-ben még csak két kar hirdetett meg idegen nyelven szakot, amire jöhetnének „,igazi” külföldi hallgatók. A diplomakredites hallgatók többsége határon túli magyar diák. Időközben a Gépészmérnöki és Informatikai Kar is kifejlesztett angol nyelvű mesterszakot. A műszaki karok dékánjai féltek alapszakot idegen nyelven meghirdetni, ami a brazil program esetében egyértelműen veszteséget jelentett (mindösszesen 4 diák választotta Miskolcot), mert Brazíliából elsősorban alapszakos hallgatók jelentkeztek.

16. táblázat: A Miskolci Egyetem nemzetközi mobilitását jellemző fó adatok szervezeti egységek szerint (2010/2011)

\begin{tabular}{|c|c|c|c|c|c|c|c|c|c|}
\hline $\begin{array}{l}\text { Jellem- } \\
\text { zők }\end{array}$ & $\begin{array}{l}\text { Müszaki } \\
\text { Földtud. } \\
\text { Kar }\end{array}$ & $\begin{array}{l}\text { Müszaki } \\
\text { Anyag- } \\
\text { tud Kar }\end{array}$ & $\begin{array}{l}\text { Gépész } \\
\text { Infor- } \\
\text { mati- } \\
\text { kai } \\
\text { Kar }\end{array}$ & ÁJTK & GTK & BTK & $\begin{array}{l}\text { Egész- } \\
\text { ségtu- } \\
\text { domá- } \\
\text { nyi } \\
\text { Kar }\end{array}$ & $\begin{array}{l}\text { Come- } \\
\text { nius } \\
\text { Főis- } \\
\text { kolai } \\
\text { Kar }\end{array}$ & $\begin{array}{l}\text { Bartók } \\
\text { B. } \\
\text { Zene } \\
\text { Int. }\end{array}$ \\
\hline $\begin{array}{l}\text { Külföldi } \\
\text { hallgatók } \\
\text { aránya } \\
(\%)\end{array}$ & 0,98 & 1,29 & 1,8 & 0,72 & 2.04 & 3,31 & 3,8 & 4,49 & 1,16 \\
\hline $\begin{array}{l}\text { Külföldi } \\
\text { részkép- } \\
\text { zésben } \\
\text { részt vevő } \\
\text { hallgatók } \\
\text { aránya } \\
(\%)\end{array}$ & 0,49 & 0,55 & 0,74 & 0,43 & 1,48 & 0,39 & 0 & 0,28 & 1,16 \\
\hline $\begin{array}{l}\text { Kiutazó } \\
\text { alkalma- } \\
\text { zottak } \\
\text { aránya } \\
(\%)\end{array}$ & 141 & 88,5 & 123,1 & 66,2 & 78,7 & 95,7 & 2,6 & 3,7 & 0 \\
\hline $\begin{array}{l}\text { Idegen } \\
\text { nyelven } \\
\text { meghir- } \\
\text { detett } \\
\text { szakok } \\
\text { száma }\end{array}$ & 3 & 0 & 0 & 0 & 1 & 0 & 0 & 0 & 0 \\
\hline
\end{tabular}




\begin{tabular}{|l|l|l|l|l|l|l|l|l|l|}
\hline $\begin{array}{l}\text { Joint } \\
\text { degree } \\
\text { jellegü, } \\
\text { közös } \\
\text { képzési } \\
\text { együtt- } \\
\text { mükö- } \\
\text { dések } \\
\text { száma }\end{array}$ & 1 & 0 & 0 & 1 & 0 & 0 & 0 & & \\
\hline $\begin{array}{l}\text { Nem- } \\
\text { zetközi } \\
\text { intézmé- } \\
\text { nyi part- } \\
\text { nerkap- } \\
\text { csolatok } \\
\text { száma }\end{array}$ & 28 & 34 & 76 & 31 & 50 & 73 & 2 & 0 & 0 \\
\hline
\end{tabular}

Forrás: www.femip.hu Intézményfejlesztési tervek TABL_17 és TABL_27

A külföldi részképzésben részt vevő hallgatók aránya a Gazdálkodástudományi Kart (GTK) és a Bartók Béla Zeneművészeti Intézetet leszámítva 1\% alatt van, ami meglehetősen alacsony. Ennek fő oka a hallgatók alacsony nyelvi felkészültsége, szociális háttere és a motiváció hiánya. A diákok többsége nem lehetőségként, hanem kényszerként fogja fel, hogy külföldre menjen tanulni. A kreditek teljesítése, az elégséges jegy megszerzése az alapvető cél.

Az alkalmazottak kiutazásainak számát tekintve korreláció van a nemzetközi intézményi kapcsolatokkal, ezen belül az Erasmus kapcsolatokkal. Habár a források szűkülése miatt itt is stagnálásra lehet számítani. Ebben a helyzetben jól jön a Campus Hungary programja, amely segíti a piacmegismerést. Tavasszal részt vettek 14 egyetem társaságában a kínai úton, amely során Xiam több egyetemét látogatták meg. Két éve müködik Kína Központ az egyetemen, közvetlen rektori irányítás alatt, ahol már 160 hallgató vette fel a kínai nyelvet, és amely központ hamarosan Konfucius Intézet lesz. (Van nyertes pályázatuk a nemzetközi stratégia kidolgozására, és az észak-magyarországi régió felsőoktatási intézményeivel való együttműködés fokozására).

A vezetői elköteleződés a számokból láthatóan, ha szavakban meg is van, a tettekben kevésbé nyilvánul meg. Hiányzik a célokhoz a megfelelő erőforrás. Ez vonatkozik a bérekre, az adminisztratív létszámra, a feladatok személyre szabására. Például a Campus Hungary részlegesen támogatja a 2013. szeptemberi EAIE konferencián való megjelenést Isztambulban. Szakmailag egyértelműen indokolt lenne részt venni, de nem tudják hozzátenni a saját részt a finanszírozáshoz.

A nemzetközi feladatokkal kapcsolatos szabályozás és információáramlás szerepel az SZMSZ-ben, de nem elégséges. Az érintett oktatók és adminisztratív dolgozók túlterheltek, emiatt az írásos, egyirányú kommunikáció nem elégséges. Személyes ráhatás kell, hogy megtörténjenek az események, a karokon nincs külön ember. A Tudományos és Nemzetközi Osztályon az oktatói státusú vezető mellett korábban 3+2 fő dolgozott. A nemzetközi ügyekkel foglalkozó 3 főből július 1-től 2 fő lett.

A nemzetközi tevékenység finanszírozásának az Erasmus támogatás a fö területe. Nincs egységes rálátás a kari folyamatokra, bevételekre, illetve a különböző pályázatokra. Régen működött egy arab iroda 2 fővel. A Rektori Hivatal utazási kerete 2,3 millió forint. 
Oktatásszervezési szempontból elkülönül a külföldi hallgató. Nemzetközi akkreditációval nem rendelkeznek. A távoktatás területén mérlegelik ennek lehetőségét. A Műszaki Földtudományi Kar joint degree jellegű közös képzési programja az Erasmus Mundus ${ }^{23}$ keretében zajlik, és hozzájárul a kar dolgozóinak és hallgatóinak intenzív utazásaihoz. A külföldi hallgatói toborzást segítő ügynöki szerződéssel nem rendelkezik az egyetem.

\subsection{Eszterházy Károly Főiskola}

„Nagy célokhoz könnyű út nem vezet” - kezdte a sajtótájékoztatót Dr. Liptai Kálmán, kinevezett rektor, kiemelve, hogy a föiskolával szeretne „nagyot alkotni”. Úgy látja, a jelenlegi csapatban benne rejlik az a lehetőség, hogy elérjék a távoli célokat. Mindehhez az alapok már megvannak - hangsúlyozta, majd hozzátette, „értelmes kompromisszumokkal és változtatásokkal valami egészen újat szeretnénk építeni”. A 2013. július 1-én hivatalba lépő új vezetés által július 15-én tartott sajtótájékoztatón az egri tanárképzés kiemelt szerepéről is beszélt Dr. Liptai Kálmán. Elmondta, hogy a főiskola új vezetése szeretné beilleszteni a 21. század valóságába a tanárképzést úgy, hogy mindebben kiemelt hangsúlyt fektetnek egyebek közt az emberi kapcsolatokra és az élményközpontúságra. Külön szólt arról is, hogy az új szemlélet kialakításához külföldi követendő példák megismerésén és integrálásán is dolgozik majd az intézmény; fontosnak tartja, hogy az EKF munkatársai lássák, milyen eredményekkel és módszerekkel rendelkeznek a legjobb külföldi intézmények. Ugyanakkor arra is felhívta a figyelmet, hogy a tanárképzésen kívüli szakok továbbra is fontos szerepet játszanak majd a főiskola működésében. Forrás: www.ekf.hu/ujweb/ index.php?page $=35 \&$ nid $=3942$

A nemzetköziség és a matematika tanításának élményközpontúsága jelenik meg az elsőként szervezett 2 hetes és 3 kreditet nyújtó nyári egyetemen, amelyre egyaránt vártak diákokat és tanárokat. ${ }^{24} \mathrm{~A}$ neves hazai és külföldi előadók között volt Szemerédi Endre Abel-díjas világhírü magyar matematikus is.

A Főiskola hallgatói létszáma évek óta stabilnak mondható, 6500-7000 között mozog, és az új tanévben, 2013 szeptemberében az előző évet meghaladó számú új hallgató iratkozhat be az intézménybe. Mindösszesen 100 külföldi diák, döntően cserediák, karonként eltérő arányban és számban tanul a föiskolán, akik közül kb. 10 fő az, aki ösztöndíjasként diplomaszerző kurzusokat látogat. Fizetős külföldi hallgató gyakorlatilag nincs. A Bölcsészettudományi Főiskolai Kar (BTK) vezeti a karok rangsorát, mind a 2\%-os beutazó, mind az 1\%-os kiutazó hallgatói arányt illetően (1\%. táblázat). A Gazdaság- és Társadalomtudományi Kar (GTK) két szakot is hirdet angol nyelven, alap- és mesterszintű „nemzetközi tanulmányok” témakörben. A harmadik angol nyelven meghirdetett szak a Tanárképzési és Tudástechnológiai Karon (TKTK) a mozgóképkultúra témakörében még nem tudott elindulni elegendő hallgató hiányában. Közös diplomát nem adnak ki más főiskolával, jóllehet a TKTK részéről volt ilyen irányú szándék.

23 „A Kar tagja a FEMP-nek (Federation of European Mineral Programs, Európai Bányászati Képzési programok Szövetsége) melynek keretében három EMC (European Mining Course), EMEC (European Mineral Engineering Course) EGEC (European Geotechnical and Environmental Course) képzési program érhető el, amely képzésekbe hallgatókat küldünk és hallgatókat fogadunk. A FEMP munkájában részt vevő mintegy 35, többségükben multinacionális cég mellett a következő egyetemeken folyik képzés: RWTH Aachen, a TU Delft, a HUT Helsinki, Exeter, TU Berlin, TU Wroclaw, TU Freiberg, TU Kosice, Uni. Miskolc MFK. A kurzusok angol nyelven folynak, egyeztetett program alapján. A képzés 2008-tól az EU „Erasmus Mundus” programja keretében angol nyelvü mesterképzés formájában folytatódik." www.mfk.uni-miskolc.hu/1_f.html

24 European Summer School for Visual Mathematics and Education July 13 - 25, 2013. in cooperation with University of Jyväskylä, Sint-Lucas School of Architecture, University of Applied Arts Vienna, ICT College of Vocational Studies, University of Novi Sad, Belgrad Metropolitan University, Mathematical Institute of the Serbian Academy of Sciences In the frame of the TEMPUS IV. project, Visuality \& Mathematics: Experiential Education of Mathematics through Visual Arts, Sciences and Playful Activities, this year we organize a Summer University for teachers, undergraduate students, mathematicians, artists and for all the inquiring people. 
17. táblázat: Az Eszterházy Károly Fơiskola nemzetközi mobilitását jellemzö fö adatok szervezeti egységek szerint (2010/2011)

\begin{tabular}{|l|l|l|l|l|}
\hline Jellemzők & BTK & GTK & TKTK & TTK \\
\hline Külföldi hallgatók aránya (\%) & 2,05 & 1,58 & 1,00 & 1,04 \\
\hline Külföldi részképzésben résst vevő hallgatók aránya (\%) & 1,06 & 0,90 & 0,31 & 0,22 \\
\hline Kiutazó alkalmazottak aránya (\%) & 0,52 & 1,18 & 6,67 & 2,90 \\
\hline Idegen nyelven meghirdetett szakok száma & & & & \\
\hline Joint degree jellegü, közös képzési együttműködések száma & 0 & 0 & 0 & 0 \\
\hline Nemzetközi intézményi partnerkapcsolatok száma & & & 6 & \\
\hline
\end{tabular}

Forrás: www.femip.hu Intézményfejlesztési tervek TABL_17 és TABL_27

A nemzetközi intézményi partneri kapcsolatokat intézményi szinten szervezik, jóllehet a szerződések többsége (90\%) karokhoz kötődik. A legerősebb partnereik Törökországban vannak, ahonnan tanári és diák csereprogramok keretében is van ki- és beutazás. Az alkalmazottak a Tanárképzési és Tudástechnológia Karon utaznak a legintenzívebben, de még ez a 7\%-hoz közelítő arány sem magas. Ugyanakkor a trend bíztató, és a vezetés tudatosan ösztönzi a munkatársakat a kapcsolatépítésre, külső források megpályázására. Az elkövetkező években itt is lényeges változásra lehet számítani. Ami a vezetés elkötelezettségét illeti, korábban nem volt igazán prioritás a nemzetközivé válás. Ez az, ami most markánsan megváltozott. Stratégiai szintű elköteleződés jelei mutatkoznak az új és fiatal vezetés részéről

A nemzetközi rektorhelyettesi pozíció önállóvá vált. Korábban a központi külügyi igazgató mellett 2 munkatárs dolgozott a nemzetközi területen. Az új rendszerben nagy hangsúlyt helyeznek a nyelvi képzésre, mivel a nyelvi tudás és vizsga hiánya korlátozza a külföldi programokra való jelentkezést, illetve a diploma kiadását is. Ennek érdekében a külügyi igazgató szervezetébe fog tartozni a Nyelvi Intézet (14 fö), a Mobilitási Központ (3 fö), az Intézményi Kapcsolatépítési Központ (3 fó) és egy újonnan létrehozandó Interkulturális Központ (3 fö). A karok és vezetőik megértették, hogy csak központi összefogással lehet lényegesen előrelépni, és ehhez koncentrálni kell az erőket. Az így létrehozandó 23 fós szervezet a meglévő állományt 3 fővel gyarapítja. Minden bekerülő hallgató nyelvi teszten esik át, és a tudásának megfelelő csoportba kerül. Heti 4, illetve 8 órás keretben lesz lehetőség nyelvet tanulni, hogy egy év után mindenki elérje legalább a B1 szintet, ami után legkésőbb 1 év múlva nyelvi vizsgát is képes tenni.

A szaknyelv elsajátítása és a külföldi útra való felkészítés két szinten történik. Egyrészt a magasabb, ún. C1-C2 szinten a társadalom- és természettudomány 12 szakterületén lesz lehetőség szaknyelvet tanulni. Másrészt az angolul meghirdetett szakokon a nyelvvizsgával rendelkező hallgatók ösztönözve lesznek, hogy legalább egy tárgyat idegen nyelven teljesítsenek. A nemzetközi tanulmányok szakon már ma is ez a gyakorlat. Ott azjelenti majd az előrelépést, hogy nem lehet a szakot elvégezni külföldi tapasztalat nélkül.

Ugyanezt az áttörést akarják elérni a tanárok és részben az adminisztratív területen dolgozók esetében is. A tanulmányi adminisztrációt ellátó Hallgatói Centrum vezetője ment legutóbb Pekingbe egy vásárra, és kapcsolatot építeni egy kínai egyetemmel. A docenseknek elvileg képesnek kellene lenni ide- 
gen nyelven is tárgyat meghirdetni és tanítani, de nem ez a helyzet. Augusztus folyamán a nemzetközi rektorhelyettes tervezi, hogy minden karral, tanszékkel konzultál (,roadshow-t tart”), ahol ismerteti a stratégiai koncepciót és az operatív teendőket. Az információáramlás személytelen, írásos vagy online formája nem elégséges ahhoz, hogy átmenjen az üzenet. A tanárok nyelvi és szakmai felkészítését 2 hónapos külföldi utakkal alapozzák meg, ahol a partneregyetemekkel szerződnek egyfajta „tutori” támogatás érdekében. Jelenleg 3-4 amerikai és 2-2 német illetve osztrák intézménnyel folyik a megállapodás előkészítése. Cél, hogy 1 év múlva minden szakon legyen olyan tanár, aki képes idegen nyelven tanítani.

A minőségbiztositást nemzetközi akkreditáció, illetve nemzetközi konzorciumokhoz való tartozás révén nem tudják ellenőrizni, mert eddig ilyenre nem volt példa, és egyelőre nincs is törekvés. A bejövő hallgatók integrálásában fontos szerepe van a tutori rendszernek, amelyet a hallgatói önkormányzat szervez, de nem elég hatékonyan. A jövőben ezt mind a bejövő, mind a kimenő hallgatók vonatkozásában az Interkulturális Központ fogja szervezni, támaszkodva a hallgatói közreműködésre.

Az oktatásszervezésben a nemzetközi aspektus eddig nem jelent meg, nem volt rá igény. A jövőben a nemzetközi kapcsolatokban jól hasznosítható, modulszerű, rövid programok (mint a korábban említett nyári egyetem) kínálatát kívánják erősíteni. A művészeti képzésben, mint rajz, ének, hangszer stb., különösen nagy tere lehet ennek, amihez ugyan fel kell készíteni a tanárokat, de kisebb szerepe van a verbális kommunikációnak, mint magának a produkciónak, tapasztalatnak. Ez is lehet az útja a fizetős programok beindításának.

A főiskola finanszírozása a nehézségek ellenére stabil. Jelentős infrastrukturális fejlesztést hajtottak végre, és emiatt 2011-ben még 10 milliárdos volt a költségvetés, ami 2012-ben 6 milliárd forint körül alakult. Nincs pontos kimutatás arról, hogy a nemzetközi tevékenység milyen összegbe kerül. Az önköltséges tandíjak a minisztériumi irányszámok alsó tartományában helyezkednek el (Nappali BA 158000 Ft/szemeszter, az MA képzés $183000 \mathrm{Ft} /$ szemeszter).

\subsection{Budapesti Müszaki és Gazdaságtudományi Egyetem}

„A Müegyetemre összesen felvettek száma változatlan maradt: idén 5152-en kezdhetik meg nálunk tanulmányaikat (2012-ben 5166-an). Ez a kitűnő eredmény nem járt együtt a felvettek pontszámának romlásával: csak magas felvételi pontszámmal lehetett hozzánk bekerülni. ${ }^{25}$ Az alapképzéseinkre felvettek átlagpontszáma 411!"www.bme.hu/hirek/20130724/a_BME_sok_szeretettel_-koszonti_hallgatoit

Ebben a létszámban nincs benne a külföldi hallgatók száma, akik a brazil programnak köszönhetöen kb. 50\%-kal növelik meg az újonnan felvett külföldi hallgatók számát. A BME jelentős erőfeszítéseket tett a számára kedvező, a műszaki képzést preferáló, és a Magyar Rektori Konferencia által szervezett programban való sikeres részvételért. A BME egyik tanára éppen egy brazil egyetemen tanított, és őt kérték fel, hogy reklámozza a BME szakjait Brazíliában. A terv szerint 460 brazil hallgatóból, aki egy éves részképzését Magyarországon tölti, kb. 240 fő 2013 szeptemberében a Műegyetemen kezdi meg a tanulmányait. Jelentős részük már meg is érkezett a nyár folyamán, és angol nyelvű képzésen vesz részt. Ezáltal megfordul egy negatív trend a külföldi hallgatóktól származó tandíjbevételt illetően. Ugyanis 2007 és 2011 között 600 millióról 450 millió forintra csökkent az idegen nyelven folyó képzés tandíjbevétele.A 9000 dolláros éves tandíjjal számolva a 240 brazil hallgatótól származó bevétel 220 forintos árfolyamon kalkulálva 475,2 millió forint árbevételt jelent a 2013/2014-es tanévben.

$25 \mathrm{Az}$ újonnan felvett hallgatókat a Villamosmérnöki és Informatikai Karon, a honlapon a Masat-1 névre keresztelt műholdról is üdvözölték. 2007 szeptemberében Magyarországon, egy lelkes BME hallgatókból és doktoranduszokból álló csoport elhatározta, hogy megtervez és megépít egy kisműholdat, amely a Masat-1 nevet kapta és már egy éve a föld körül kering. Az alkalmazás segítségével a kis mühold életét mindenki nyomon követheti. 
A BME összes hallgatóinak a száma az elmúlt 5 esztendőben 22000 főről 23000 före növekedett, miközben a külföldi hallgatók száma abszolút és relatív értékben is csökkent, 1050 főről 938 före, azaz 4,6\%ról 4,0\%-ra, amivel az országos átlag (5,6\%) alatt maradtak. A karok között nagy eltérések vannak, hiszen az Építészmérnöki Kar 9,3\%-ával szemben a Közlekedésmérnöki és Járműmérnöki Kar csak 1,6\%-ot fogad (18. táblázat). A külföldi részképzésben részt vevőhallgatók aránya szintén az Építészmérnöki karon a legmagasabb (3,4\%), míg a Természettudományi Kar (TTK) produkálja a legalacsonyabb (0,4\%) szintet. Ebben szerepet játszik, hogy a hallgatók nem elég ambiciózusak a külföldre menetelt illetően. Jóllehet a bekerülő hallgatók átlagosan 1-nél magasabb nyelvvizsgával rendelkeznek, nem elég magabiztosak a tudásukat illetően. Az angol nyelvü tárgyak felvételét az egyetem szorgalmazza, de nem teheti kötelezővé. Az Erasmus és a CEEPUS mellett a Karlsruhei és a Bécsi részképzés, valamint néhány további kétoldalú megállapodás keretében kiutazó hallgatók növelik ezt a mutatót.

18. táblázat: A Budapesti Müszaki és Gazdaságtudományi Egyetem nemzetközi mobilitását jellemzö fó adatok szervezeti egységek szerint (2010/2011)

\begin{tabular}{|c|c|c|c|c|c|c|c|c|}
\hline Jellemzők & $\begin{array}{l}\text { Építő } \\
\text { Kar }\end{array}$ & $\begin{array}{l}\text { Gépész } \\
\text { Kar }\end{array}$ & $\begin{array}{l}\text { Épi- } \\
\text { tész } \\
\text { Kar }\end{array}$ & $\begin{array}{l}\text { Vegyész } \\
\text { Bio } \\
\text { Kar }\end{array}$ & $\begin{array}{l}\text { Villamos } \\
\text { Inf } \\
\text { Kar }\end{array}$ & $\begin{array}{l}\text { Közlekedés } \\
\text { Jármü } \\
\text { Kar }\end{array}$ & $\begin{array}{l}\text { Gazdasági } \\
\text { Társtud } \\
\text { Kar }\end{array}$ & TTK \\
\hline $\begin{array}{l}\text { Külföldi } \\
\text { hallgatók } \\
\text { aránya (\%) }\end{array}$ & 5,6 & 3,8 & 9,3 & 3,0 & 4,7 & 1,6 & 2,0 & 4,2 \\
\hline $\begin{array}{l}\text { Külföldi } \\
\text { részkép- } \\
\text { zésben } \\
\text { részt vevő } \\
\text { hallgatók } \\
\text { aránya (\%) }\end{array}$ & 1,1 & 1,6 & 3,4 & 1,5 & 1,2 & 0,7 & 1,4 & 0,4 \\
\hline $\begin{array}{l}\text { Kiutazó } \\
\text { alkalmazot- } \\
\text { tak aránya } \\
(\%)\end{array}$ & 50 & 70 & 30 & 100 & 73 & 100 & 58 & 36 \\
\hline $\begin{array}{l}\text { Idegen } \\
\text { nyelven } \\
\text { meghirde- } \\
\text { tett szakok } \\
\text { száma }\end{array}$ & 3 & 4 & 3 & 2 & 6 & 3 & 1 & 1 \\
\hline
\end{tabular}




\begin{tabular}{|l|l|l|l|l|l|l|l|l|}
\hline $\begin{array}{l}\text { Joint } \\
\text { degree jel- } \\
\text { legü, közös } \\
\text { képzési } \\
\text { együttmű- } \\
\text { ködések } \\
\text { száma }\end{array}$ & 1 & 3 & 1 & 1 & 3 & 1 & & \\
\hline $\begin{array}{l}\text { Nem- } \\
\text { zetközi } \\
\text { intézményi } \\
\text { partner- } \\
\text { kapcsola- } \\
\text { tok száma }\end{array}$ & 47 & 118 & 46 & 65 & 134 & 129 & 53 & 2 \\
\hline
\end{tabular}

Forrás: www.femip.hu Intézményfejlesztési tervek TABL_17 és TABL_27

Az egyetemi vezetés a küldetésében is megfogalmazta a nemzetközi színvonalra való törekvést, de a mobilitásnál vannak magasabb prioritást jelentő területek. Az alkalmazottak nagy része utazik évente külföldre, de a tanárok jelentős része is inkább magyarul tanít, nem függetlenül a tanszékek profiljától, kormegoszlásától, tudásától. Az idegen nyelven meghirdetett szakok mind angol nyelvűek, amelyben a Villamosmérnöki és Informatikai Kar (VIK) vezet 6 szakkal. Minden kar rendelkezik joint degree jellegü, közös képzési együttműködéssel is. A „közös képzések” között a „Bécsi Részképzés” minden Kart érint, a Karlsruhei a VIK-et és a Gépészmérnöki Kart, míg az egyes karok francia nyelvű közös képzést folytatnak a Paristech-kel (VIK, TTK) és az Ensam CLUNY-val (Gépész Kar) és a Jean Moulin Lyon 3-mal. A Villamosmérnöki és Informatikai Kar az egyetlen, amelynek külföldi telephelye is van.

A BME működésében az elmúlt időszakban a költségvetési gazdálkodás átláthatósága miatt is a $k a-$ rokra mint diviziós egységekre helyeződött a hangsúly. A korábban központilag szervezett idegen nyelvü oktatási központ, a TANOK megszűnt, és feladatait az oktatási területen a karok vették át. Az oktatási rektorhelyettes (mint egyedüli szakterületi rektorhelyettes az általános rektorhelyettes mellett) felügyeli a Központi Tanulmányi Hivatalt, ahol mindösszesen 38 fóállású munkatárs dolgozik. Ezen belül található meg az Erasmus és Csereprogramok Irodája (3 fö), amely együttműködik a kari felelősökkel. A Nemzetközi Oktatási Iroda (4 fö) foglalkozik a külföldi diplomakredites hallgatókkal. A Nemzetközi és Tudományos Csoport ( 4 fö) fogja át az egyetemi nemzetközi kapcsolatokat, amelyek több kart is érintenek. A stratégiai cél a racionalizálás, kevesebb központi utazás, a kiválóságra való törekvés, mint a szelekció alapja, és a tanszéki, intézményi tartalmi kapcsolatépítés.

A korábban említett „Bécsi Részképzés” a regionális vezető szerepre törekvés egyik megnyilvánulása is, amelyben 4 műszaki egyetem (Bécsi, Prágai, Pozsonyi, Budapesti) egy-egy szemeszterre fogadja a társintézmény hallgatóit, amely megjelenik a diplomakiegészítésben. Az ilyen, illetve az ehhez hasonló, nagy horderejü programok, mint a brazil program, új megvilágításba helyezték a nemzetközi tevékenység szabályozását, a karok közötti információáramlást, amely a hatékony központi reagálóképességet csak korlátozottan szolgálja. Elindult a központi nemzetközi szervezetek összevonása, amely egyidejűleg szemléletváltozást is igényel a karok, illetve az érintett szervezeti egységek részéről.

Régebben, amikor a tudományos és nemzetközi rektorhelyettesi pozíció létezett és a portfóliójába 
tartozott a központi tudományszervezési és nemzetközi tanulmányszervezési részleg (TANOK), egyértelműen növekedési trend érvényesült a külföldi hallgatók számában is. Úgy tűnik, hogy a korábban jelzett negatív trend megváltoztatására született vezetői elhatározás szervezeti következményekkel is fog járni. Az oktatásszervezésben nem válik el a magyar és a külföldi hallgató, mindkettőt a Központi Tanulmányi Hivatal bonyolítja. A funkcionális rektorhelyettesi pozíciók 5 évvel ezelőtti megszüntetésével (egyetlen általános rektorhelyettes létezett csak) a dékánok munkaköri leírásában megjelentek bizonyos rektorhelyettesi feladatok is, mint pl. az innováció vagy a tehetséggondozás. Ennek a központi szervezet szempontjából takarékos megoldásnak, felemás struktúrának kétségtelenül voltak negatív következményei az információáramlásra nézve.

A BME rendelkezik egységes angol nyelvü Bulletinnel, amelyben a kurzusleírások kari bontásban szerepelnek. Vannak alaptantárgyak, mint pl. matematika, fizika, amelyeket minden kar számára a TTK oktat. A karok közötti „átoktatásnak” egyértelmü finanszírozási rendszere van, ami az idegen nyelvü képzésre is vonatkozik. Ha tartalmilag egybevonnánk az idegen nyelvü képzésekbe fektetett kari és egyetemi szintű tevékenységet, akkor kb. 1 milliárd forintos költségvetéssel kellene számolni a 33 milliárdos egyetemi összkiadásból.

Egyre fontosabbá válik a külföldi diákok számára nyújtott szolgáltatás színvonala. Ebben a hallgatók, illetve a hallgatói önkormányzatok is részt vesznek, esetenként pályázati rendszer alapján. Jelenleg többféle mentor program létezik (Erasmus, ún. harmadik országbeli hallgatók, brazil hallgatók stb.), amelyek nem mindig nyújtják a legmagasabb színvonalat, de tehermentesítik a fóállású munkatársakat, ezért szükség lenne a harmonizálásra.

\subsection{Central European University, Közép-európai Egyetem}

„Egyetemünk az Amerikai Egyesült Államokban és a Magyar Köztársaságban akkreditált budapesti székhelyü felsőoktatási intézmény, amely posztgraduális képzést nyújt a társadalomtudományok, a bölcsészettudományok, a közgazdaságtudomány és a jogtudomány terén. Intézményünk kiemelten foglalkozik a társadalmi változások interdiszciplináris és összehasonlító kutatásával, a nyílt társadalmakba történő átmenet modelljeinek tanulmányozásával, valamint a nem nyugati fejlődési típust követő demokráciák elemzésével. Egyetemünk nagy hangsúlyt fektet az Európai Unió intézményrendszerének és bővítési lehetőségeinek tanulmányozására is.” www.ceu.hu

A CEU-honlap kezdő mondatai rávilágítanak arra, hogy itt egy különleges, a Hrubos-Horváth (2012) U-Map klasszifikáció szerinti nemzetközi egyetemről van szó. Egy magánegyetem, amelyet nagyrészt a Soros Alapítvány finanszíroz. A nemzetközi mobilitás értelmezése problémát jelent, hiszen ez az egyetem nemzetközinek született, és annyiban magyar, hogy Magyarországra települt. Az egyetem 35 programjából 15 van Magyarországon akkreditálva. A $8 \mathrm{PhD}$ programjából $2 \mathrm{PhD}$ programot a MAB is akkreditált. A hallgatók száma 1500, akiknek több mint egyharmada $\mathrm{PhD}$ hallgató. Kutatóegyetem, ami azt jelenti, hogy az oktatók idejüknek több mint felét kutatásra fordítják, ami megnyilvánul az intenzív publikálásban. A 180 fóállású és kb. ugyanennyi részidős, vendégoktató 14 tanszék és két school keretében tevékenykedik. A tanárok 40\%-a magyar, és több mint 30 országot reprezentál. (A 20 tagú kuratóriumban viszont csak egy magyar található, Chikán Attila.)

A diákok 20\%-a magyar, 10\%-a amerikai, majd románok, horvátok, szerbek stb. következnek, akik 93 nemzetet jelenítenek meg. Az egyetem kb. 100 Erasmus partnerszerződés mellett több száz egyéb nemzetközi szerződéssel rendelkezik. Maga a „nemzetközi” jelző is vitatható, hiszen egy New York államban bejegyzett egyetemnek minden magyar partnerrel való szerződés definíció szerint nemzetközi. Az alapításkor még a közép-európai átmenetre koncentráló egyetem a jövőben a nyílt társadalom globális 
problémáit is kutatja. Így pl. az arab tavaszt vagy néhány ázsiai, afrikai ország helyzetét, ami hatással van a hallgatótoborzásra is.

Az egyetem működése az amerikai rendszert követi, ahol professzionális adminisztráció tevékenykedik az intézményfenntartástól, a kutatási pályázatok menedzselésén át a hallgatói toborzásig. Kiemelendő a volt diákok szervezete, amely már most is nagyban hozzájárul az új hallgatók ide irányításához. Jelenleg több mint 50 országban működik helyi szervezete (chapter). Fiatal szervezetként pénzügyi értelemben még nem jelentős a hozzájárulás a fenntartáshoz, de mentális értelemben igen, hiszen az itt végzettek jelentős pozíciókat töltenek be hazájukban. Sokan NGO-oknál dolgoznak, ahol nem a jó fizetés dominál, hanem a társadalmi megújuláshoz való hozzájárulás. A három rektorhelyettes (működésért, akadémiai ügyekért és magyar és európai ügyekért felelős) közül az akadémiai, oktatási ügyekért felelős rektorhelyettes természetszerűleg nemzetközi szinten gondolkodik, hisz az oktatás csak angol nyelven folyik és a kutatási eredmények megitélése is az angol nyelvű publikációk alapján történik. Az intézmény logikájából adódóan a magyar és európai ügyek számítanak „nemzetközinek”.

A minőségbiztositást az amerikai és MAB akkreditáció jelenti, nem törekednek más szervezetek elismerésére. A méretükből adódóan a nagy rangsorokban nem számíthatnak előkelő helyezésre, ha viszont az egy főre vetített mutatószámokat nézzük, akkor sok területen élen járnak. A hallgatói kurzusértékelés mellett minden hallgató a tanulmányai befejeztével is kitölt egy általános kérdőívet (exit survey). A tanárok évente készítenek önértékelést, amelyet a tanszék értékel. A 180 fóállású oktatóból 50 professzor. Az Európai Kutatási Tanács (ERC) által 2012-ben megítélt, egyenként 1,5-2 millió eurós, öt évre szóló kutatási projektekből a 10 közép-európai nyertesből 3 CEU-s professzor volt. Nagyon jól szerepeltek az FP6 és FP7 uniós projektek elnyerésében is.

Az emberi erőforrást illetően nagy előny, hogy minden pozíciót nemzetközi pályázatok alapján töltenek be. Ebből adódóan a legjobb nemzetközi gyakorlatok a személyek révén, a mindennapokban, mindenféle kampány nélkül épülnek be a szervezetek életébe, legyen szó oktatási vagy egyéb szervezetről. A 350 fő körüli adminisztratív dolgozónak 80\%-a helyi, azaz magyar, de a külföldiek itt is fontos vezetői posztokat töltenek be. A mindennapi kommunikációban nagy szerepe van az angol nyelvtudásnak. Vállalati és uniós kutatásokkal összhangban (Berács et al. 2013), úgy érzékelik, hogy a magyar diákok (jelentkezők) nyelvtudása elmarad a román, horvát vagy szerb diákokéhoz képest. Miután ide egyetemi alapdiplomával érkeznek a hallgatók, ebben a közoktatás mellett már az egyetemi oktatás is felelős.

\subsection{Eötvös Loránd Tudományegyetem}

„A 2013-as felvételi eljárásban is a legnépszerűbb magyar felsőoktatási intézmény az Eötvös Loránd Tudományegyetem, hiszen a legtöbben valamely általuk kínált képzést választották első helyen. Az ELTE arányaiban több hallgatót tudott felvenni, mint tavaly: bár a bekerülők abszolút létszáma kismértékben csökkent, az ELTE-re 2013-ban bejutó 8200 elsőéves hallgató az összes jelentkező közel 9\%-át jelenti, többet, mint 2012-ben. A hozzánk jelentkezők több mint negyven százalékát felvehettük.” www.elte.hu

„Az ELTE stratégiája a minőség stratégiája - az ELTE képzéseire jutottak be a legnagyobb arányban a legjobb továbbtanulók." A széles közvéleményt tájékoztató honlap vezércikke részletesen beszámol arról, hogy milyen pontszámokkal lehetett bejutni a következő ábrán szereplő nyolc karra, ahol a felvettek számát olvashatjuk.

A minőségi hallgatók érdeklődése miatt az első helyes jelentkezők az ELTE-n voltak a legtöbben, és jó eredményeket is értek el, ezért önköltséges helyekre a korábbi évek 44\%-os aránya helyett csupán 23\% jutott. A kormány finanszírozási politikája miatt ezt az örvendetes tényt az ELTE vezetése kockázati 
tényezőként értékeli, azaz aggódik, hogy az állam megtéríti-e a valóságos költségeket az egyetemnek. Külföldi hallgatók érkezéséről, nagyságáról, változásáról, esetleges kedvenc szakokról nem esik szó a honlapon.

4. ábra: A 2013-ban felvettek száma

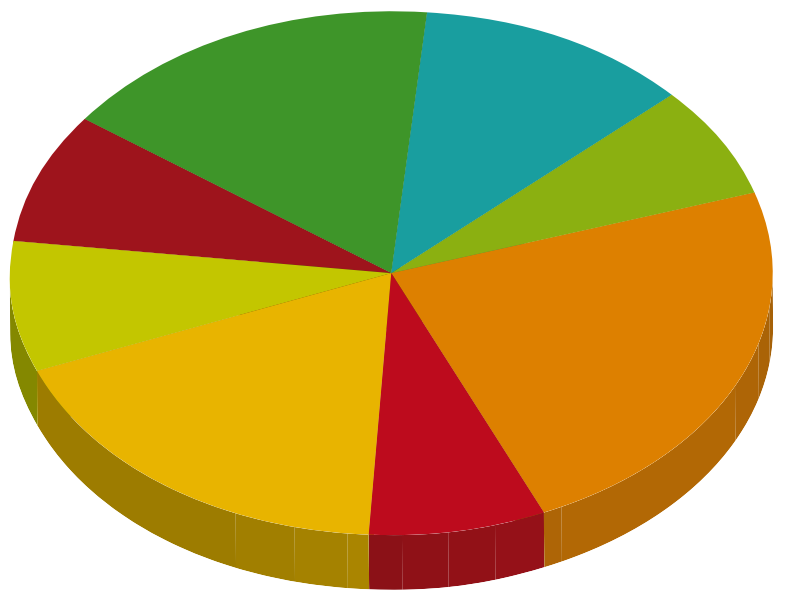

AJTK 970

BGGYK 577

BTK 1933

IK 632

PPK 1478

TATK 683

TOK 662

TTK 1338

Az ELTE 2012-es vagyonmérlegében 47,033 milliárd forint eszközállomány szerepel, amelyből 4,781 milliárd a forgóeszköz állomány. A kiadások között 395 millió forintot, az eredeti előirányzat kétszeresét teszi ki a külföldi kiküldetés. A felhalmozási kiadások 3,666 milliárd forintot tettek ki a 31,918 milliárdos összkiadásból. A működési bevételeken belül a „szolgáltatások ellenértéke” 3,620 milliárd forintot tett ki. Vélhetően ezen belül szerepel a külföldi hallgatók tandíjaiból származó bevétel is, de nem látható külön sorban. Becslést sem végeznek ennek meghatározására, mert a bevételek a karokon jelennek meg. Az egyetemen 3013 teljes munkaidőben foglalkoztatott közalkalmazott 9,849 milliárd forint, míg a 476 részmunkaidőben foglalkoztatott dolgozó 644 millió forint személyi juttatásban részesült. A nemzetközi funkciócsoportra engedélyezett költségvetési létszámkeret 1+7fó. A közszféra és a magánszféra együttműködésén (PPP) alapuló szerződéses konstrukció hosszú távú kötelezettségvállalásának állománya 9,707 milliárd forint. Forrás: www.elte.hu/file/ELTE_2012_eves_beszamolo.pdf

A külföldi diplomakredites hallgatók 3,6\%-os arányával az ELTE az állami felsőoktatási intézmények rangsorában a 12. helyet foglalja el, lényegesen elmaradva az 5,2\%-os országos átlagtól. Ha a külföldi hallgatóktól származó tandíjbevételeket néznénk, akkor még nagyobb a lemaradás. Az Erasmus és más csereprogramban beérkező külföldi hallgatókat együtt vizsgálva (19. táblázat) három kar, a Bölcsész, az Informatikai és a Társadalomtudományi Kar emelkedik ki, 6,5 és 6,8\%-os aránnyal. Itt vannak idegen nyelven meghirdetett szakok, amelyben a Bölcsész Kar jár az élen 20 szakkal. Az egyetem legnagyobb karát csak a Természettudományi Kar (TTK) előzi meg a nemzetközi intézményi kapcsolatokban és a kiutazó alkalmazottak arányában. A közös diplomák kiadásában is a Bölcsész Kar vezet az Informatikai Kar és a TTK előtt. 
19. táblázat: Az Eötvös Lóránd Tudományegyetem nemzetközi mobilitását jellemzö fö adatok szervezeti egységek szerint (2010/2011)

\begin{tabular}{|c|c|c|c|c|c|c|c|c|}
\hline Jellemzők & $\begin{array}{l}\text { Állam } \\
\text { és } \\
\text { Jogtud. } \\
\text { Kar }\end{array}$ & $\begin{array}{l}\text { Bárczi } \\
\text { G. } \\
\text { Gyógyp. } \\
\text { Kar }\end{array}$ & $\begin{array}{l}\text { Böl- } \\
\text { csész } \\
\text { Kar }\end{array}$ & $\begin{array}{l}\text { Infor- } \\
\text { matikai } \\
\text { Kar }\end{array}$ & PPK & $\begin{array}{l}\text { Tanító- } \\
\text { és Óvó- } \\
\text { képző } \\
\text { Kar }\end{array}$ & $\begin{array}{l}\text { Társ- } \\
\text { tud. } \\
\text { Kar }\end{array}$ & TTK \\
\hline $\begin{array}{l}\text { Külföldi hallga- } \\
\text { tók aránya (\%) }\end{array}$ & 1,80 & 3,38 & 6,00 & 5,00 & 3,69 & 0,74 & 6,80 & 1,50 \\
\hline $\begin{array}{l}\text { Külföldi részkép- } \\
\text { zésben részt vevő } \\
\text { hallgatók aránya } \\
(\%)\end{array}$ & 2,70 & 1,25 & 2,00 & 1,00 & 1,16 & 0,94 & 1,70 & 0,50 \\
\hline $\begin{array}{l}\text { Kiutazó alkalma- } \\
\text { zottak aránya (\%) }\end{array}$ & 7,30 & 6,50 & 27,00 & 10,00 & 3,85 & 7,14 & 5,40 & 37,12 \\
\hline $\begin{array}{l}\text { Idegen nyelven } \\
\text { meghirdetett } \\
\text { szakok száma }\end{array}$ & 0 & 0 & 20 & 1 & 2 & 0 & 1 & 0 \\
\hline $\begin{array}{l}\text { Joint degree } \\
\text { jellegü, közös } \\
\text { képzési együtt- } \\
\text { működések } \\
\text { száma }\end{array}$ & 0 & 0 & 3 & 2 & 0 & 0 & 0 & 2 \\
\hline $\begin{array}{l}\text { Nemzetközi } \\
\text { intézményi part- } \\
\text { nerkapcsolatok } \\
\text { száma }\end{array}$ & 126 & 93 & 145 & 64 & 52 & 32 & 140 & 210 \\
\hline
\end{tabular}

Forrás: www.femip.hu Intézményfejlesztési tervek TABL_17 és TABL_27

Az elmúlt két esztendőben jelentős növekedés következett be az idegen nyelven meghirdetett szakok számában. A honlap 2013 augusztusában már 46 szakról számol be (a 2010-ben megadott 31 szakkal szemben), amelyek megoszlása: PhD 26, MSC és MA 9, BSC és BA 11. Ezek a nagyságok a tudományos elkötelezettséget jelzik, de a piaci igényekhez kevésbé alkalmazkodnak. A Pedagógiai és Pszichológiai Kar (PPK) a két PhD és egy-egy MA valamint BA szakjával élen járt a fizetős hallgatók toborzásában. (850 Euro/félév tandíj mellett kb. 40 föt fogadnak évente). A Bölcsész Kar viszont 5 éve stratégiai irányként fogalmazta meg, hogy 2015-re 500 fő legyen a devizakülföldi hallgató. Ennek érdekében megerősítették a Tanulmányi Osztályon belül a nemzetközi ügyekkel foglalkozó adminisztratív szervezetet. 2013.szeptemberben várhatóan 252 ilyen hallgató kezdi el a tanulmányait. 
A honlapon a szabályzatok és dokumentumok címszó alatt az SZMSZ mellett 14 egyéb szabályzat jelenik meg, de egyik sem foglalkozik a nemzetközi tevékenységgel. A Nemzeti Felsőoktatásról szóló CCIV. Törvény szellemében aktualizált 83 oldalas SZMSZ tartalomjegyzékében nem szerepel a nemzetközi tevékenység. Az egyetem feladataként felsorolt 12 tevékenység (4.\$1. bekezdés) között sem jelenik meg a nemzetközi tevékenység. Az egyetemi szintű szolgáltató egységek között lenne lehetőség a nemzetközi tevékenységet professzionálisan űző, a diplomás illetve fizetős külföldi hallgatók menedzselésére. A 44.\$ kimondja, hogy „(3) Kari szintű funkcionális egységként titkárság, hivatal, osztály, csoport, iroda elnevezésű egységek hozhatók létre” Itt a tételes felsorolásban szerepel a „nemzetközi” megnevezés is. A Rektori Titkárság gondoskodik a rektor Nemzetközi kapcsolattartásáról. A szenátus által létrehozott 20 bizottságból a „Hallgatói és Oktatói Mobilitási Bizottság”26, valamint az „Idegen Nyelvű Képzést Koordináló Bizottság”"27 érintett közvetlenül is a nemzetközi tevékenységben.

Az ELTE-re a nagyfokú kari (tanszéki, intézeti) önállóság jellemző a nemzetközi tevékenységet illetően is. A vezetés elvileg elkötelezett ezen a téren, de ez nem jelenik meg praktikus, gyakorlati célokban sem az IFT-ben, sem az egyéb stratégiákban. Annak ellenére ez a helyzet, hogy az elmúlt években, részben az IFT készítése, részben az Erasmus Charter megfogalmazása kapcsán nőtt a tudatosság, illetve a bevezetőben említett kiválóság, vezető szerep több ponton tetten érhető. A kiutazó Erasmus hallgatók számában például 518 fővel a 2011/12-es tanévben magasan vezettek az országban (a BME és az SZTE előtt), de a fogadásban (350 fő) már elmaradnak, és sokat kell tenni, hogy a külkereskedelmi szempontból „import többletet” megszüntessék, azaz egyensúlyba kerüljön a két utazási irány. (A legutóbbi tanévben sajnos kevesebb pályázó volt, ezért az 1,2 millió euro-s éves költségvetési tervből kb. 54000 eurót nem használtak fel. A korábban a hallgatók számára nyújtott 50/75/110 ezer forintos szociális kiegészítő támogatás, amelynek legnagyobb éves kerete 12 millió forint volt, 2012-ben megszűnt. A Campus Hungary keretében 200 hallgatót tudtak mobilizálni az elmúlt esztendőben.)

Az SZMSZ-ben is rögzített 8 fős Nemzetközi Képzési és Mobilitási Osztály a Nemzetközi Rektor helyetteshez tartozik. Az osztály koncepciója a 2005-2009-es periódusban egy szerves fejlődés eredményeként jött létre. Korábban három központi területen voltak megtalálhatók. A Pályázati és Innovációs Központ foglalkozott az Erasmus és CEEPUS, pályázati pénzekből fenntartott csereprogramokkal. Az Oktatási Igazgatósághoz tartoztak a diplomás képzésben részt vevő külföldi hallgatók, míg az intézményi nemzetközi kapcsolatépítési feladatokat a Rektori Titkárság látta el. Az új osztály 2009, január 1-jével alakult meg 2,5 fővel, majd a feladatok átcsoportosításával, központosításával érte el jelenlegi létszámát. A nyolc karon önálló, vagy megosztott portfólióval rendelkező nemzetközi dékánhelyettesek vannak, akik mellett mindösszesen 15 adminisztratív státuszú személy dolgozik. Az oktatók nemzetközi tevékenységhez kapcsolódó adminisztratív, szervezési feladatai jelentősek, de teljes idejű munkaidőben való meghatározására nem vállalkoztak.

26 Hallgatói és Oktatói Mobilitási Bizottság 106. §

(1) A Socrates/Erasmus és CEEPUS programok egyetemi szintű feladatainak felügyeletére, a hallgatói és oktatói mobilitás végrehajtásával kapcsolatos döntések meghozatalára, valamint a programok hatékony szervezése érdekében a Szenátus ELTE Hallgatói és Oktatói Mobilitási Bizottságot hoz létre.

(2) Az ELTE Hallgatói és Oktatói Mobilitási Bizottság karonként egy oktatóból és az EHÖK által delegált egy főből áll, elnöke a tudományos rektorhelyettes. Hatáskörére és működésére rektori utasításban megállapított ügyrend vonatkozik.

27 Idegen Nyelvü Képzést Koordináló Bizottság 112. §

(1) Az Egyetem az idegen nyelvű képzés összehangolása, fejlesztése érdekében Idegen Nyelvü Képzést Koordináló Bizottságot hoz létre, amely az egyetemi vezetés számára véleményeket, javaslatokat fogalmaz meg az idegen nyelvü képzésekre vonatkozóan, különösen az ilyen képzésben részt vevő hallgatók számának növelése, új képzések indításának ösztönzése, valamint a külföldi szerepvállalás erősítése céljából.

(2) Az Idegen Nyelvű Képzést Koordináló Bizottság tagjai a rektor által felkért elnök és társelnök, a karok által delegált egy-egy tag, az EHÖK képviselője, továbbá a Gazdasági és Műszaki Főigazgatóság egy munkatársa, a Bizottság munkájában tanácskozási joggal részt vesz a Rektori Hivatal Oktatási Igazgatóságának, valamint Nemzetközi Képzési és Mobilitási Osztályának vezetője. 
Ami a finanszírozást, a költségeket és a bevételeket illeti, meglehetősen töredezett a kép. A központi osztály bérkerete 24 millió forint, dologi költségek 2 millió forintot tettek ki, a központi utazási keret 17 millió forint, amely kiegészítésre szorul a rektori tartalékból. A közbeszerzés kapcsán megbízott utazási iroda évente 1500 megrendeléssel dolgozik, ami 220 millió forintot jelent. A külföldi hallgatóktól származó bevétel lényegesen megnő és transzparensé válik a brazil programnál, amely keretében 41 fo" érkezik (TTK 32 fó, IK 9 fó). A 7800 dolláros éves tandíj mellett várhatóan 70 millió forint bevétel képződik, ami egyharmada a becsült 220 milliós eddigi árbevételnek. Ügynöki szerződésük jelenleg csak három van, aminek az is oka, hogy egy nagyon részletes, az 5/2012-es rektori utasításban szabályozott, 16 oldalas dokumentum, a közbeszerzési rendelkezések figyelembevételére hivatkozva, az éves maximális jutalék összegét is tartalmazza.

A nemzetközi minőségbiztositást illetően a közös képzések között kiemelkedik a két Erasmus Mundus program, a BTK és az ÁJTK karok szervezésében. A konzorciumi tagokkal való együttmüködés, a bonyolítás magas szakmai követelményt támaszt. A Heidelbergi Egyetemmel 30 éve fennálló csereprogramban évente 2 fö utazhat ki 10 hónapra, ahol németül és angolul kell tudni és a népszerüségét jelzi, hogy 20-25 jelentkezőből kell választani. Évente egy egyhetes nyári egyetemet is tartanak Budapesten 10-10 fö részvételével. A Konfucius Intézet 5 éve alakult és a kínai nyelv tanítása mellet a kínai diákok vonzása, gondozása is szerepel feladatai között. A ki- és beutazó hallgatók, oktatók véleményét az Erasmus előíráson túl, általában nem mérik. Rendszeres visszajelzést néhány nyári egyetemnél végeznek. A nemzetközi rangsorokban elfoglalt helyek szakterület specifikusak (pl. fizikában hetedikek Európában), központilag kevésbé tudják megítélni és nem is nagyon használják. A BTK is előkelő helyezést ért el a Financial Times rangsorában. Emellett fontos a szerepük a nemzetközi diplomáciában. A Kar ad helyszínt sok külföldi politikus magyarországi előadásának, amelyet megalapoz a Külügyi Intézettel való szerződés, illetve az évente a külföldi nagykövetek számára tartott rendezvény.

Ami az oktatásszervezést illeti, a külföldi hallgató jelenleg még csak akkor tud regisztrálni az ETR-ben illetve a Neptunban, ha megérkezik. Emiatt sok előzetes egyeztetésre van szükség a tanszékekkel, oktatókkal a tárgyak elfogadását illetően. Jelenleg nincs egyetemi katalógus, amit utoljára 2009-ben készítettek 150 angol és német nyelven futó tárgyat bemutatva. A karok eltérő gyakorlatot folytatnak a magyar hallgatók befogadását, a fizetős és nem fizetős hallgatók közötti átjárást, illetve a karok közötti átjárást illetően. A Társadalomtudományi Kar a leginkább nyitott, amit az is jelez, hogy 45 cserehallgatót fogad, miközben 20 hallgatót küld külföldre. A Bárczy Gusztáv Gyógypedagógiai Kar 30-50 kredites tantárgy csomagot állít össze, amit csak az egyik szemeszterben hirdet meg. Az Informatikai Karon népszerű az Erasmus intenzív egyhetes nyári egyetem, amelyet egy konzorcium tart 110 fő részére. A külföldi hallgatók a tutori rendszer ellenére eléggé izoláltak. Az oktatók terhelésébe az idegen nyelven tanított tárgy általában nem számít bele, mondván, hogy ez alapvető kötelesség, elvárás az ELTE-n, miközben egyértelműen több munka, és ha más motiváció nincs, a díjazás hiánya a vállalkozó kedvet lerontja.

A BTK karon folyó számtalan idegen nyelvű szak miatt is az idegen nyelven történő képzés természetes közeg ott is, ahol nincs a szak akkreditálva idegen nyelven. Az 550 oktató közel 100\%-a PhD-val rendelkezik, és 57 külföldi lektor is dolgozik a karon. Az alapszakok mellett számtalan szakirány (minor) felvételére is lehetőség van. Az összes szak-kombináció révén közel 3000 féle diplomát lehet a hallgatónak megszerezni. A piaci kereslet a hagyományos szakokról áttolódott az interdiszciplináris szakokra (pl. Közel-Kelet tanulmányok). 


\subsection{Pázmány Péter Katolikus Egyetem}

A Pázmány Péter Katolikus Egyetem legrégebbi karát a Hittudományi Kart (HTK) a névadó, 1635-ben alapította $^{28}$. Az önálló hittudományi intézményből 1992-ben, a Bölcsészet- és Társadalomtudományi Kar (BTK) megalapításával lett igazi egyetem, amelyen később Jog- és Államtudományi Kar (JÁK), valamint Információs Technológiai és Bionikai Kar (ITK) alakult. A korábban önálló Vitéz János Katolikus Tanítóképző Kar, amely Esztergomban található, 2013-tól Pedagógiai Központként a BTK kereteiben működik. A 8000 hallgatót számláló egyetem legnagyobb kara, a BTK Piliscsabán, a Makovecz Imre által tervezett campuson jött létre. A közel 3000 fős hallgatói létszám kisebb részét kitevő mester és doktori képzés 2013 szeptemberétől beköltözött Budapestre és velük együtt a Nemzetközi osztály is.

Az egyetem az Erasmus mobilitásban mindig az élmezőnyhöz tartozott. Már 2005-ben 100 fős kiutazó hallgatóval az 52 intézményből a 8. helyet foglalta el, míg a 2012/13-as tanévben kiutazó 150 fóvel, és a számukra nyújtott szolgáltatásokkal a TKA éves értékelésében az előkelő 9. helyet szerezték meg. A négy kar nagyfokú önállósággal dolgozik általában és a nemzetközi területen pedig kifejezetten. A BTK mellett a jogi kar jeleskedik még jelentős mobilitási adatokkal. Az ITK profiljából és vezetői szakmai rátermettségéből adódóan jelentős kutatási projektekkel rendelkezik, amely egyelőre még nem egészül ki intenzív hallgatói mobilitással. A vezetés elkötelezett a nemzetköziesítés irányában és megtette az első lépéseket az egyetemi szinten történő egységesítésre, a szinergiák kiaknázására. Mindezidáig elsősorban az egyének és a tanszékek, karok szintjén történt az aktivitás. Jóllehet az egyházi egyetemnek nem kellett intézményfejlesztési tervet készíteni, ők megtették (még ha nem is publikusak az adatok). Ebben önálló fejezet a „külügyi stratégia”, amely fö iránya a közös képzések erősítése.

Jelenleg egy közös képzésük van az ICES francia egyetemmel, de megszületett két újabb keretszerződés, francia és spanyol egyetemmel, amely a következő tanévtől indulhat be. Idegen nyelven jelenleg 3 nyelvszak van akkreditálva (anglisztika mesterszak angol nyelven, francia nyelv, irodalom és kultúra mesterszak francia nyelven, és olasz nyelv, irodalom és kultúra mesterszak olasz nyelven). Van törekvés, fejlesztés további szakok angol nyelvű indítására, de eddig még nem jártak sikerrel. Ez is hozzájárul ahhoz, hogy a bejövő kb. 130 Erasmus hallgató kiszolgálása több munkát igényel, mintha lenne központi egyetemi katalógus, illetve nagyobb mértékű áthallgatás az egyes karok hallgatói számára. Jelenleg nincs igazi fizetős hallgató, miként ügynöki szerződéssel sem rendelkeznek. Most kezdik bevezetni a kurzusdíjakat, illetve fejlesztenek féléves modult. Az oktatók kisebb része (kb. negyede) vállalkozik idegen nyelvü kurzusok tartására.

A nemzetközi tevékenység finanszírozása elsősorban a pályázatokon alapszik. Legjelentősebb tétel a 2013/14-es tanévre szerződött 330000 eurós Erasmus keret, amelyet ők maximálisan kihasználnak, sőt rendszeresen kiegészítő támogatást is igényelnek és kapnak. Ezzel tudják növelni a 330 euró/fö/hó hallgatói támogatást, amelyhez az egyetemnek nincs külön forrása. Van viszont utazási keret, amelyből évente 80000 forint/főre lehet pályázni, amit szükség esetén dékáni keretből egészítenek ki.

Az intézményi mobilitási folyamatok jól szabályozottak, a Tanulmányi és Vizsgaszabályzat (TVSZ) tartalmazza, központi mintatanterv alapján, a be- és kiutazó hallgatók kredit elismerési folyamatait, míg az Erasmus és CEEPUS programok külön eljárásrendben is rögzítve vannak. (A központi mintatantervben jelenik meg, hogy a kiutazó hallgatónak is kell 25 kreditet teljesíteni, amely alól csak kivételes esetben adnak felmentést.) Az egyetemi honlapon az „idegen nyelvü képzések” alatt csak a BTK jelenik meg, illetve az említett három idegen nyelvű szak. A Nemzetközi osztály is, ahova el lehet jutni az oldalról,

28 A három nagyszombati alapítású egyetem, a PPKE, az ELTE és a Semmelweis Egyetem 2012-ben stratégiai megállapodást kötött Nagyszombati Felsőoktatási és Kutatási Szövetség néven. Ennek keretében kiemelt partnerként kezelik egymást a nemzetközi színtéren is, amit megerősít a ELTE-PPKE-SE Nemzetközi Universitas Fórum. A szövetséget tovább erősíti, hogy a PPKE is „kiemelt egyetem" statust kapott.. 
a BTK-ra irányul. A kurzuslista a bölcsész sajátosságot tükrözi. Az 55 szabad kurzusból 38 angolul, 11 németül és 3-3 franciául, olaszul és spanyolul vehető fel. Emellett a teljes angol (66), francia (38) és olasz (40) képzés a saját nyelvén megy. (A zárójelben szereplő számok a meghirdetett előadás/szemináriumi csoportokat jelzik, amelynél kisebb a tényleges kurzusválaszték.)

Az egyetem 130 nemzetközi partnert tart számon a különböző kategóriákban, amelyek között átfedések vannak. Legjelentősebb az Erasmus (96), amit a CEEPUS (23) követ. Következik egy közös kutatásra létrejött hálózat, IRUN (8), amely közös képzéseket is szervez nyári egyetem formájában. (IRUN = International Research University Network). A tengeren túli (overseas) kategóriában egyelőre 3 egyetem (két USA és egy tajvani) található, de cél, hogy erősítik ezt a vonalat, amit kínai rektori utazás is megalapozott. A Genti Egyetem vezetésével dolgoznak egy Erasmus Mundus pályázaton, amely az indiai katolikus egyetemek platformján kísérel meg kaput nyitni erre a régióra. Ez is a minőségbiztosítás egyik formája, amit az egyetemi és kari pályázati csoportok aktivitása is fémjelez.

A nemzetközi területen dolgozók száma a bölcsész karon 1+3 fö alkalmazott, 2 gyakornok és a mentorok hálózata, akiket a HÖK is támogat. Most formálódik az egyetemi központi szervezet, az egyéb karokon fellelhető néhány fő bevonásával. A kérdés a feladatmegosztás a központ és a karok között, illetve a központi tanulmányi osztályok és a nemzetközi osztály között. A változtatások sikere az oktatók és az alkalmazottak attitűdjének a megváltozásán is múlik. Bíztató, hogy mind az oktatói, mind a dolgozói Erasmus mobilitás növekvő. Nagyobb hangsúlyt kell fektetni a nyelvi képzésre is, minden szinten.

\section{A kutatásból levont fő következtetések és ajánlások}

A kutatási programban illetve az interjú vezérfonalban (5.1. melléklet) megfogalmazott értékalapú kérdések többségére a 16 intézmény helyzetértékelése alapján, valamint az intézmények jól felfogott nemzetközi növekedési stratégiáját feltételezve, azt kell válaszolnunk, hogy „nincs”, „,nem eléggé”, „több is lehetne”, ,alacsony”, „közepes” és folytathatnánk a sort a megoldásokban a kérdésfeltevések függvényében. Az ajánlások pedig minden esetben a nagyobb mértéket kell, hogy megcélozzák. Ebből a szempontból nincs különbség a központi és a konvergencia régió között, csupán az utóbbiban a mértéket a relativ elmaradás miatt magasabbra kell emelni.

Így például az intézményirányítás, vezetői elköteleződés kérdéskörnél feltettük azt a kérdést is, hogy: „Van-e törekvés kettős diploma vagy közös képzések indítására BA, MA, vagy doktori szinten?” Az IFT alapján egy-két kivételtől eltekintve alacsony szinten valósulnak meg közös képzések. Nem véletlen, hogy az EU több projektet is támogat, amely erre készíti fel a kevésbé aktív egyetemeket. ${ }^{29}$ Általában nem egyetemi stratégiai döntés alapján születtek meg a sikeres példák sem, hanem egy-egy tanszék, vagy kar, illetve néhány lelkes személy érdeklődése kapcsán. Emiatt az intézményen belüli elterjedése is véletlenszerü. Még maga a vezetés is szigetként tekint rá, nem pedig követendő, terjesztendő példaként. A javaslat itt is, mint mindenütt, hogy:

29 A Tempus Közalapítvány több európai Erasmus Mundus Nemzeti Irodával együtt valósítja meg az EMAP 1.,2.,az ECCE Mundus és az INTERUV - Joint Programmes - facilitator for university internationalisation ( www.interuv.eu) projekteket. A program célja egyebek között, hogy népszerüsítse az Európai Unió és az EU-val szomszédos partnerországok intézményei közötti együttműködéseket, mindenekelőtt a közös képzéseket,támogatást nyújtson a felsőoktatási intézményeknek, hogy a közös képzéseket integrálni tudják a nemzetköziesítési stratégiájukba. 
a. növelni ajánlott a közös képzéseket,

b. növelni kell a közös képzésben végzett hallgatók számát.

\section{A legfontosabb akadályozó tényező a nemzetközi mobilitás területén a vezetôi elkötelező-} dés hiánya az intézményekben. A retorikában, a szavak szintjén, a deklarációkban is tetten érhető ez a hiányosság, de leginkább ott figyelhető meg, hogy sem a stratégiában, sem a mindennapi tevékenységben nem teljesítmény orientáltak, nem output vezéreltek. A nemzetközi tevékenységet jellemző indikátorok nem közismertek. Ennek néhány területe:

a. Az uniós céllal megegyezően a magyar kormány is célul tűzte, hogy 2020-ra a felsőoktatásban végzettek 20\%-a rendelkezzen legalább egy félévnyi külföldi tanulmányi vagy szakmai gyakorlatos tapasztalattal. Egyetlen intézményben sem tapasztaltuk, hogy erre vonatkozóan célszámot fogalmaztak volna meg, illetve a jelenlegi állapotot rögzítették, vagy figyelték volna. Az intézményfejlesztési tervekben is kötelezően megjelenő „külföldi részképzésben részt vevő hallgatói arány” sem olyan szám, amit az Erasmus felelősökön túlmenően a vezetők különösebben ismernének.

b. A mobilitás pénzügyi oldala homályba vész. Ösztöndíj kiegészítés, utazási költséghozzájárulás, konferencia-támogatás, vagy más címszó alatt nyújtott támogatások a központi finanszírozási megszorítások miatt visszaszorulóban vannak, de a nagyságrendjük olyan, hogy csak „nagyítóval” lehet megtalálni. A támogatás nagy részét kitevő pályázati pénzek (az Erasmus kivételével) számbavétele is inkább utólagos és nem proaktív módon tervezett. Azt a látszólag egyszerü kérdést, hogy mibe kerül a nemzetközi tevékenység az intézményeknek, nemhogy megválaszolni, de még értelmezni sem nagyon tudták a megkérdezettek.

c. A honlap nemzetközi oldalának tartalmi és aktualitás szempontjából való elemzése rávilágít arra, hogy a kisebb intézmények kevés hírről számolnak be, illetve azok is nehezen találhatók meg, valamint a frissítésre csak ritkán kerül sor. (Volt olyan intézmény, ahol a frissítés legutóbb 2012. október 15-én történt.) Miután a honlap a legtöbbet használt kommunikációs eszköz a potenciális külföldi hallgatók és minden érintett számára, ezért szükség van arra, hogy nagyobb vezetői figyelem háruljon rá és ne csupán mint egy technikai eszközt tekintsék.

A központi és a konvergencia régiók közötti különbség a vezetôi elköteleződés szempontjából is tetten érhető, de olyan mértékben, ahogyan a mobilitási számok is eltérnek. Egyébként pedig a kontextuális tényezők függvényében nagy változatosságot mutatnak. A nemzetközi indikátorok aktuális értékeinek a növelése útján lehet a kormányzatnak növelni a vezetői elköteleződést, amit célszerű lenne valamilyen ösztönzési rendszerbe illeszteni.

\section{A nemzetközi területen dolgozók száma, szervezeti elhelyezkedése, szakmai kompe-} tenciája, nagy változatosságot mutat még akkor is, ha megpróbáljuk az összes hallgatói létszámhoz, a külföldi hallgatók számához, vagy a nemzetközi kapcsolatok számához arányosítani a tapasztalt helyzetet. A fejlődés kulcskérdése az adminisztratív fóállású szakmai stáb és az oktatói, kutatói tevékenységet párhuzamosan ellátó választott vezetői garnitúra tevékenységének az öszszehangolása. Néhány kiemelendő terület:

a. Az egyetemek mérete és szervezeti konfigurációja meghatározza a nemzetközi területen dolgozók tevékenységét. A nagy állami, illetve a piachoz rugalmasan alkalmazkodó kisebb (esetleg magán) intézményekben hasonló megoldásokat találunk, amely a mátrix típusú szervezeti forma jegyeit mutatja, ahol a nemzetközi részleg egyre inkább szolgáltató tevékenységet lát el. 
b. A nemzetközi tevékenység korábban megfigyelhető decentralizációjával szemben egy egészséges centralizáció törekvéseit ismerhetjük fel, ahol a kari határok (birodalmak) lassan oldódnak. Ez azon a felismerésen alapul, hogy a felső vezetés egyre inkább érzékeli, hogy a globális piacon az esetleges kari, intézeti, tanszéki és egyéni ambícióktól függő döntések nem hoznak átütő sikert az intézmények számára. Ezt erősíti a kormányzati külgazdasági, külpolitikai nyitás stratégiája is, amelyhez kevésbé tud 170 kar alkalmazkodni. 2013 leglátványosabb akciója ebből a szempontból a Magyar Rektori Konferencia által menedzselt brazil program.

c. A nemzetközi területen dolgozó egyének szakmai múltjával és iskolai végzettségével is jellemezhető szakmai kompetenciája javuló tendenciát mutat. Egyrészt évtizedes gyakorlati tapasztalatokkal rendelkeznek, másrészt a nyelvtudás mellett egyéb szakmai ismeretek elsajátítására is törekednek. Egyre inkább eltűnik a nemzetközi utaztatást bonyolító szervezeti attitűd és helyébe a stratégiai gondolkodást is értő mentalitás kerül. Ezt jelzi az angol nyelvtanári diploma mellett sokféle más (pl. jogi, gazdasági, mérnöki) diploma megléte, illetve $\mathrm{PhD}$ fokozat megszerzése is. Igény van a szakmai továbbképzésre, amelyhez a helyi vezetők támogatását is meg kell szerezni, ha pénzügyi konzekvenciákkal jár.

d. A rendszeres vezetőváltás során bekövetkező átszervezés, egyesek kiemelése és mások leépítése, lefokozása, nem mentes a konfliktustól, sértődéstől. Az egyetemek finanszírozási gondjai miatt 2013-ban ezek az esetek megszaporodtak. A nemzetközi ügyeket felügyelő rektorhelyettesek, dékánhelyettesek mellett a rektorok és dékánok nemzetközi mobilitási látókörének bővítésére is szükség lenne a harmonikus együttműködés érdekében.

A központi és a konvergencia régiók között a nemzetközi területen dolgozók kompetenciája, felelősségi köre, szakmai képessége szempontjából nem tapasztaltunk lényeges különbséget. Ugyanakkor a hallgató szám (valamint a motiváció) csökkenéséből származó finanszírozási gondok a felsőoktatásban erőteljesebben érintették a konvergencia régió intézményeit, ezért ott nagyobb mértékű leépítésre, illetve stagnálásra rendezkedtek be, ami nem kedvez a mobilitás területén célul tűzött felzárkózásnak.

3. Az oktatásszervezés és a minőségbiztosítás lassan összekapcsolódik a nemzetközi mobilitás területén. A hagyományos folyamatszervezés (mint pl. az ISO rendszerek bevezetése), a piaci sikert jelző nemzetközi rangsoroknak (mint pl. a Financial Times, az ARWU, QS, Webometrics, stb.) való megfelelés, valamint a rangos nemzetközi konzorciumokba (mint pl. Erasmus Mundus, közös diplomát, képzést nyújtó programok, stb.) való bekerülés jelöli ki a kapcsolódás három legfontosabb területét. Részletesebben kifejtve:

a. A tanulmányi osztályok egyre inkább képesek a külföldi hallgatók ügyeit is kezelni a NEPTUN, az ETR vagy más rendszerek közreműködésével. Ez szakmai kompetencia (pl. nyelvtudás) növelési igényt támaszt az itt dolgozókkal szemben, egyidejűleg azonban a nemzetközi területen dolgozóknak is el kell sajátítani ezt az ismeretet, hogy az elkerülhetetlen személyes kapcsolatokban megfelelő tájékoztatást tudjanak nyújtani.

b. A nemzetközi rangsorokban egyre nagyobb súllyal veszik figyelembe a nemzetközi tevékenységet, azon belül a diák, tanár, alkalmazott és vezetői mobilitást. Egyelőre még csak a nagy egyetemek és azok is csak a sikeres szereplés esetén beszélnek a rangsorokról. Nem találkoztunk olyan törekvésekkel, amelyek a rangsorban való előrelépést, illetve az előrelépés érdekében teendő nemzetközi stratégiai törekvéseket együtt jelenítették volna meg. 
c. A nemzetközi konzorciumokban való részvétel, a közös diploma nyújtása ma még szigetszerüen jelenik meg az egyetemek gyakorlatában. Az Intézményfejlesztési Tervben kötelezően megadandó külföldi telephelyek pedig olyanok, mint a fehér holló, és azok is inkább kisebb intézmények kihelyezett tagozatai.

A központi és a konvergencia régiók között különbséget a tanulmányi osztályok nemzetközivé válása, valamint a nemzetközi konzorciumokban való részvételt illetően érzékeltünk a központi régió javára. Ennek oka elsősorban az, hogy a központi régióból a mintánkban szerepelt egy igazi nemzetközi egyetem, a CEU is. Nélküle már nem markánsak a különbségek.

\section{A hazai irányítású nemzetközi pályázatok egyértelmü nyertese a konvergencia régió, amely ez alapján is differenciálódott a nagy univerzitások javára.}

A felsőoktatás alulfinanszírozottsága kapcsán felmerülő vitákban gyakori probléma, hogy az intézmények vezetői (miként a Magyar Rektori Konferencia) az oktatási célra szánt források csökkenéséről beszélnek, míg a kormányzati emberek szívesen emlegetik a pályázatokból beáramló pénzeket is. Az egyik oldal példátlan pénzkivonásról, míg a másik oldal, jelentős pénzbeáramlásról szól. A 2007-2013 közötti európai uniós programozási időszak egyik kiemelt kedvezményezett körét a felsőoktatási intézmények alkották. A felsőoktatási intézmények együttesen 2012 augusztusáig legalább 250 milliárd forint értékü támogatást ${ }^{30}$ nyertek el és szerződtek le, amelynek 44\%-át a három nagy vidéki egyetem (PTE, SZTE, DE) nyerte el.

Javaslat: Célszerű lenne az elmúlt 7 éves időszak nemzetközi forrásból származó bevételeit intézményekre és témakörökre bontva kimutatni, illetve összevetni a következő 7 éves időszak (2014-2020) várható bevételeivel, majd összefüggésbe hozni a mobilitási adatokkal.

5. A megfelelő nyelvtudás hiánya korlátozó tényező a mobilitás minden területén és a végzett hallgatók hazai és európai munkaerő-piaci versenyképességének is korlátozó tényezője. Különösen a hátrányos konvergencia régióban fontos, hogy az intézmények és a kormányzat is tudatosan foglalkozzanak a hallgatók nyelvtudásának fejlesztésével. A nemzetköziesedést intézményen belül kell kezdeni, de egyidejűleg az egész magyar hallgatói állományt és annak idegen nyelvi kommunikációs képességét teljes körüen érdemes monitorozni. Ennek megvalósítására javasoljuk a mobilitási létra kidolgozását, amely egyben tükrözi a hallgatók nyelvi képességét is. A mobilitási létra hétfoka a következő:

Első fok: a felvett hallgatók nyelvtudásának monitorozása a nyelvvizsgák alapján és ennek előrehaladása a tanulmányaik során a diploma megszerzéséig.

Második fok: nemzetközi környezet megteremtése otthon, idegen nyelven hallgatott tárgyak kreditértékének követése, külföldi hallgatókkal közös kurzusok aránya a képzésben.

Harmadik fok: rövid tanulmányok, tanulmányutak szervezése külföldön. A Campus Hungary program ezt is beemelte a támogatások körébe.

Negyedik fok: a legtöbbet tárgyalt szakasz, amikor egy teljes félévet (30 kreditet), szakmai gyakorlatot teljesit a hallgató külföldön. Ez áll az Erasmus és a CEEPUS programok középpontjában, és az EU valamint a kormányzat 2020-ra kitűzött célrendszerében.

30 „Ebből 2011 végéig 2400 oktatót képeztek ki, $180 \mathrm{~K}+\mathrm{F}$ projektet támogattak, 1000 Bologna-konform tananyag készült, 40 szabadalmat és oltalmi kérelmet jegyeztek be, 1900 tudományos cikket publikáltak, $110000 \mathrm{~m}^{2}$ oktatási-kutatási célú teret építettek. A legnagyobb fejlesztések a Debreceni Egyetemen, a Szegedi Tudományegyetemen és a Pécsi Tudományegyetemen valósultak meg, amelyek a források 44\%-át nyerték el.” Forrás:http://hetfa.hu/2013/05/a-felsooktatast-celzo-programok-ertekelese, 4. o. 
Ötödik fok: a szendvics program, amikor a hallgató a magyarországi tanulmányai (legalább egy év) beszámításával egy külföldi egyetem diplomáját is megszerzi (pl. a Dunaújvárosi Főiskola által működtetett SQA-HND közös diploma).

Hatodik fok: amikor a hallgató egy nemzetközi hálózat közös diplomáját is megszerzi (pl. a Corvinus Egyetem CEMS diplomája).

Hetedik fok, amikor a hallgató külföldön szerez diplomát, függetlenül a magyarországi tanulmányaitól. A fizetőssé váló szakokon várható a hallgatók számának csökkenése és nagyobb mértékű külföldre áramlása. Az OECD és nemzeti statisztikákból utólag ismerhetjük meg a most 10000 före becsült létszámot.

Szükség van a fenti mobilitási létra minden fokának stratégiai szintű kezelésére. Míg az első fok a konvergencia régióban található főiskolák számára kulcskérdés a felzárkózást illetően, a hetedik fok az elvándorlás szempontjából nemzetpolitikai kérdés. Aki a teljes tanulmányát külföldön folytatja, az nehezebben tér haza, kevésbé integrálódik be a magyar munkaerőpiacba.

\section{Felhasznált irodalom}

Bander Katalin (2012): Vállalt küldetések az intézményi honlapok alapján, in: Hrubos (2012 szerk.): Elefántcsonttoronyból világítótorony, 72-102.

Berács József - Bander Katalin - Hubert József - Nagy Gábor (2013): „Összegzőtanulmány és piackutatás a magyar felsőoktatás versenyképességérôl, pozíciójáról a felsőoktatási mezőnyben” Kutatási tanulmány, BCE-NFKK, TÁMOP 4.2.4B/1-11/1-2012-0001 projekt a Tempus Közalapítvány megbízásából, 2013. március, 94.

Berács József (2012): Nemzetköziesedési trendek és intézményi megfelelés, in: Hrubos Ildikó (szerk.) Elefántcsonttoronyból világítótorony - a felsőoktatási intézmények misszióinak bővülése, átalakulása, Aula Kiadó, 135-179.

Berács József - Malota Erzsébet - Zsótér Boglárka (2011): A magyar felsőoktatás nemzetköziesedésének folyamata 2, Bologna Füzetek 8, Tempus Közalapítvány, 143.

„Campus Hungary K+F projektekhez és képzési programokhoz kapcsolódó nemzetközi hallgatói mobilitás személyi támogatási rendszerének fejlesztése országos program" - Nemzeti Kiválóság Program, TÁMOP 4.2.4.B/1-11/1, Petabyte Nonprofit Kft., Balassi Intézet, Kutatási beszámolók:

Fókuszcsoportos kutatás, 49.

Szakértői interjúk elemzése, 101.

Online kvantitatív kutatás, 224.

Ennew, Christine T. - Fujia, Yang (2009): Foreign Universities in China: a case study, European Journal of Education, 44(1), 21-36.

A felsőoktatást célzó programok értékelése - 7Hétfa - Revita Alapítvány - Új Széchenyi Terv, 2013. február 28. Tanulmányok:

Értékelési zárójelentés, 169.

Esettanulmányok, 322.

Hrubos Ildikó (2012) (szerk.) Elefántcsonttoronyból világítótorony - a felsőoktatási intézmények miszszióinak bővülése, átalakulása, Aula Kiadó

Hrubos Ildikó - Horváth Ákos (2012): Kísérlet a magyarországi felsőoktatási intézmények fó típusainak azonositására, in: Hrubos (2012) Elefántcsonttoronyból világítótorony, Aula Kiadó, 25-71.

„A konvergencia régiókban tanulmányokat folytató hallgatók mobilitási stratégiájának összeállítása. 
A mobilitási ösztöndíjakhoz kapcsolódó aktivitás elősegítését megalapozó helyzetfeltárások” Nemzeti Kiválóság Program, TÁMOP 4.2.4.B/2-1-11/1-2012-0001 projekt, Soreco Research Kft., Balassi Intézet, Kutatási tanulmányok:

Konvergencia régiós intézményekre vonatkozó statisztikai adatelemzés kialakitása, mobilitási ösztöndíjak megalapozását szolgáló adatbázisok kialakitása, elemzése, 77.

Szakértői interjúk a konvergencia régiók felsőoktatási intézményeinek munkatársaival a mobilitási trendek és stratégiák megismeréséhez kapcsolódóan, 31.

Kutatási projekt a konvergencia régiók felsőoktatási intézményeinek korábban mobilitási programban részt vett hallgatói körében a külföldi tapasztalatokról, illetve a mobilitási ösztönzés kialakitásáról, növelésérőll, 63.

Az oktatói és felsőoktatási munkatársi attitüd vizsgálata a nemzetközi mobilitás vonatkozásában, a konvergencia régiókban, 39.

A konvergencia régiókban tanuló hallgatók mobilitási programba történö bevonásának, lehetöségeinek modellezése az érintettek körében végzett kutatási tevékenységek alapján, 79.

A konvergencia régiókban tanuló külföldi hallgatók körében a mobilitási tapasztalatok feltérképezése - A három legnagyobb vidéki egyetem tanulmányozásán keresztül, Campus Hungary Program, Ketzal Kft., Balassi Intézet, 135.

Kováts Gergely (2012): Intézményirányítás - a stratégiai szemléletmód esélyei, in: Hrubos (2012 szerk.): Elefántcsonttoronyból világítótorony, Aula Kiadó, 243-292.

Kutatási Szimpózium (TAMOP 424/B1 és B2), 2013. március 21, Balassi intézet, Budapest

„A felsőoktatási hallgatói mobilitás és a felsőoktatás nemzetköziesítéshez kapcsolódó nemzetközi trendeket vizsgáló tevékenység”, Campus Hungary Program, Metaforum Központ Kft, Balassi Intézet, Tanulmányok:

Mobilitási ország-tanulmányok, 2012. augusztus, 259.

Külföldi nemzeti mobilitási rendszerek vizsgálata, 2012. október, 72.

Migráció a felsőoktatásban - Kutatási tanulmány a magyarországi felsőoktatásban tanuló harmadik országbeli állampolgárokról - Bevándorlási és Állampolgársági Hivatal, Danka Balázs, 2010. november, 35 .

Mobilitás - A jogszabályi környezet vizsgálata, Feltáró háttér-tanulmány a Campus Hungary projekthez, Budapest-Pécs, 2012, Kézirat, Balassi Intézet, 53.

RédeiMária-TelbiszErzsébet-Nemes-Nagy Anna(2007):Erasmus oktatóimobilitás-Magyarországról kiutazó oktatók jellemzése kérdőívek alapján (2005/2006, HOPPÁ, Disszeminációs füzetek 14., 37.

Temesi József (2012) (szerk.): Felsőoktatás-finanszírozás, Nemzetközi tendenciák és a hazai helyzet, Aula Kiadó

Veroszta Zsuzsanna (2012): A regionalitás szerepe - a Közép-Magyarország régió, in: Hrubos (2012): Elefántcsonttoronyból világítótorony, Aula Kiadó, 105-132. 


\section{Mellékletek}

\subsection{Interjú vezérfonal - A mobilitást akadályozó és ösztönző intézményi tényezők}

Az országos hatókörü, intézményi szintű vizsgálat célja a mobilitást akadályozó és ösztönző intézményi tényezők, valamint jó gyakorlatok általános összegyüjtése mintaszerűen, amely révén javaslatok tehetők a felsőoktatási intézmények nemzetközi működésére, mobilitási programokban való részvételükre, a mobilitásra felkészítő programok fejlesztésére, valamint a mobilitás ösztönzésére vonatkozóan.

Az intézményi szintű akadályozó és ösztönző tényezők vizsgálatában a célországok (Európai Unió és harmadik országok) szerinti különbségek megállapítása, a regionális sajátosságok kimutatása. Minden témakörnél, kérdésnél az akadályozó és ösztönző tényezők, jó gyakorlatok tudakolása.

1. Az Intézmény néhány számszerü jellemzője a mobilitás szempontjából:

Hallgató szám, külföldi hallgatószám, regionális megoszlás, diploma és részképzés

Az intézmény „nemzetközi kitettségi mutatója” a mobilitási számok alapján

Külföldi partnerek száma, megoszlása

\section{Intézményirányítás, vezetöi elkötelezödés}

Egyetemi küldetésben, misszióban miként jelenik meg a mobilitás?

Hogyan mérhető, értékelhető a vezetői elköteleződés?

Milyen kiemelt nemzetközi célokat tartalmaz az IFT? Van-e összefüggés az Erasmus Charter for Higher Education dokumentumban leírt stratégiával?

Van-e nemzetköziesítési víziója, stratégiája az intézménynek?

Képzési programok tervezésénél, indításánál van-e nemzetközi kitekintés, mobilitási szempontok (mobilitási ablakok) beépítése?

Van-e törekvés kettős diploma vagy közös képzések indítására BA, MA vagy doktori szinten?

Oktatói / személyzeti mobilitásnál érvényesülnek-e intézményi stratégiai szempontok?

Kurzusmeghirdetés (ECTS katalógus)

\section{Intézményi folyamatok, szabályzatok, információáramlás}

Mennyire áttekinthetőek a szervezeti egységeken átívelő, mobilitást érintő folyamatok?

Milyen dokumentumok szabályozzák a nemzetközi tevékenységet és mennyire hatékonyan?

Hozzáigazították-e a belső szabályzatokat, eljárásokat a nemzetközi együttműködésekből adódó kötelezettségekhez, elvárásokhoz?

Milyen az információáramlás, információ-megosztás a szervezeti egységek között?

Milyen előnyök és konfliktusok forrása a tanszéki/intézeti, kari és egyetemi szintű szervezeti tagozódás?

A nemzetközi ügyekkel foglalkozó egység helye és szerepe a szervezetben?

A mobilitást megalapozó nemzetközi tevékenységeknek vannak-e támogató szervezeti egységei (curriculumfejlesztés, nemzetközi pénzügyi vonatkozások, HR, hallgatói szolgáltatások) 


\section{Finanszírozás}

Az egyetemi költségvetéshez képest milyen nagyságrendet, arányt képvisel a nemzetközi tevékenység bevétele és kiadása?

Tudott-e saját forrásokat mozgósítani az intézmény a mobilitás támogatására? Van-e szándék intézményi források bevonására, ha a körülmények lehetővé teszik?

Milyen szerepet játszik a mobilitásban a finanszírozás?

\section{Minőségbiztosítás}

Milyen minőségbiztosítási rendszerrel, akkreditációval, nemzetközi elismeréssel rendelkeznek? Milyen terveik vannak?

Milyen közös diplomaadási tapasztalatuk, törekvésük van: Milyen képzési szinten, szakterületen? Az Erasmus Mundus, Ceepus és más programok felhasználása erre a célra?

A mobilitásra való felkészítésben, a bejövő hallgatók integrálásában milyen szerepet játszanak az egyes szervezeti egységek?

Értékelik-e módszeresen és rendszeresen a ki- és beutazók visszajelzéseit? Hallgatói/oktatói/személyzeti visszajelzések.

\section{Oktatásszervezés}

Mennyire különülnek el a külföldi hallgatók a magyar hallgatóktól és egymástól? Van-e átjárás a fizetős diplomát nyújtó és nem fizetős, csereprogramok között?

A magyar nyelven tanuló magyar hallgatók tanulmányaik (kreditjeik) hány százalékában tanulnak idegen nyelven?

Milyen arányban van lehetőség a külföldi (más intézményben) végzett tanulmányok beszámítására a diplomában?

Szakmai gyakorlatok esetében adnak-e kreditet?

A kurzusleírások mennyire illeszkednek a nemzetközi elvárásokhoz (learning outcomes központúság)?

\section{\%. HR szempontok}

Mennyire motiváló a tanárok/kutatók, alkalmazottak számára a külföldi utak lehetősége?

Van-e stratégia a személyzet külföldi képzésére?

Mennyien dolgoznak a nemzetközi területen (teljes állású egyenértékes mutatószám)? Ennek aránya az összes dolgozói szinthez viszonyítva? Hogyan változott ez az utóbbi 10 évben? Hány emberre lenne reálisan szükség?

Milyen képességekkel, kompetenciákkal rendelkeznek a nemzetközi területen dolgozók? Ez hogyan viszonylik az igényekhez?

Milyen mértékbentámaszkodnak ahallgatói toborzás során azügynökökre?Milyen akapcsolattartás?

Van-e kapcsolat a részképzéses mobilitást szervező egységek és a teljes programra érkező hallgatók szervezése között?

\subsection{Interjúalanyok}

Budapest Műszaki és Gazdaságtudományi Egyetem

Jobbágy Ákos, oktatási rektor helyettes

Dvorszki László, Nemzetközi és Tudományos Csoport, igazgató 


\section{Debreceni Egyetem}

Jávor András, általános és oktatási rektor helyettes

Dunaújvárosi Főiskola

Rajcsányi-Molnár Mónika, oktatási rektor helyettes

Gyöngyössy Katalin, Nemzetközi Iroda, vezető

Eötvös Lóránd Tudományegyetem

Dezső Tamás, Bölcsészettudományi Kar, dékán

Brenner Kolomann, BTK, stratégiai ügyek dékán helyettese

Bélik Márton, Nemzetközi Képzési és Mobilitási Osztály, vezető

Eszterházy Károly Főiskola

Ráczné, Dr Horváth Ágnes, nemzetközi rektor helyettes

Tóth-Dolenszky Réka, külügyi referens

\section{Kaposvári Egyetem}

Gál Zoltán, Nemzetközi Kapcsolatok, igazgató

Kecskeméti Főiskola

Ailer Piroska, rektor

Kodolányi János Főiskola

Szabó Péter, rektor

Horváti Éva, nemzetközi képzési igazgató

Közép-európai Egyetem

Farkas Katalin, Provost and Academic Pro-Rector

Miskolci Egyetem

Bikfalvi Péter, Tudományszervezési és Nemzetközi Osztály, vezető

Nyíregyházi Főiskola

Ferencziné Dr. Ács Ildikó, Bölcsészettudományi és Művészeti Kar, dékán

Máthé Katalin, Nemzetközi Kapcsolatok Csoport, vezető

Nyugat-Magyarországi Egyetem

Varga László, tudományos és külügyi rektor helyettes

Sándor Márta, külügyi előadó

Pázmány Péter Katolikus Egyetem

Dégi Nóra, Bölcsészet- és Társadalomtudományi Kar, Nemzetközi osztályvezető

Pécsi Tudományegyetem:

Komlósi László Imre, általános és nemzetközi rektor helyettes

Pozsgai Gyöngyi, Nemzetközi Iroda, vezető

Szegedi Tudományegyetem

Pál József, nemzetközi és közkapcsolati rektor helyettes

Pálfi György, nemzetközi és közkapcsolati igazgató

Balogné Molnár Gabriella, Nemzetközi Mobilitási Iroda vezetője

Széchenyi István Egyetem

Földesi Péter, rektor

Mészáros Márta, Tudománymenedzselési és Nemzetközi Iroda, ügyvivő-szakértő 


\subsection{A Dunaújvárosi Főiskola minőségügyi rendszerének leírása}

A magyar állami felsőoktatási intézmények közül elsőként, 2003 tavaszán kapta meg intézményünk minőségirányítási rendszere az ISO 9001:2000 rendszerszabvány szerinti tanúsítást. A tanúsítvány „Felsőfokú képzés és szaktanfolyamok tartás”-ra vonatkozik. Az Intézményt a norvég székhelyü Det Norske Veritas Ltd. független minőségügyi tanúsító szervezet tanúsította. 2007-ben a Dunaújvárosi Főiskola elnyerte a Felsőoktatási Minőségi Díj bronz-fokozatát és a Fejér Megyei és Közép-dunántúli Regionális Minőségi Díjat is.

\section{Minőségirányítási Iroda tevékenysége}

Minőségirányítási rendszer működtetése és fejlesztése

Minőségirányítási dokumentumok kidolgozása, naprakészen tartása

Minőségügyi oktatások megszervezése és lebonyolítása

Felmérések készítése

Önértékelések koordinálása, audit eljárások előkészítése

Minőségügyi szakirodalom gyüjtése

A Minőségirányítási Iroda által végzett felmérések

Többkörös hallgatói felmérések

Leendő hallgatóink általános felmérése

Elsőéves hallgatók általános felmérése

Hallgatók kurzusértékelése

Oktatói munka hallgatói véleményezése

Végzett hallgatók általános felmérése

Végzett hallgatók beválás vizsgálata

Időszakos felmérések

Középiskolák véleményének felmérése

Munkatársaink megelégedettségi vizsgálata

Partneri vélemények felmérése

Záróvizsgaelnökök véleményének felmérése

A 2012. évi szervezeti átalakítások kapcsán a Minőségirányítási Iroda helyett a főtitkár irányítása alatt álló Minőségirányítás szervezet működik, 1 főállású munkatárssal.

Forrás: www.duf.hu/szervezeti-egysegek/altalanos/minosegugyi-iroda 


\section{Kreditrendszerek és alkalmazásuk Európában és a felsőoktatás globális terében}

Helyeztfeltárás és javaslatok

\section{Készítette:}

Temesi József

ISC alapítvány

A kutatás a TÁMOP-4.2.4.B/1-11/1-2012-0001 projekt keretében valósult meg.

2013. augusztus 31 . 


\section{Bevezetés}

Ha össze akarnánk gyűjteni a felsőoktatás világának elméleti és gyakorlati tárgyú szakirodalmában előforduló legfontosabb kulcsszavakat, a kredit fogalma biztosan benne lenne az első tízben. Nincs ez másképpen Magyarországon sem. Az elmúlt 25 év magyar felsőoktatása többek között a kreditrendszer megismeréséről, bevezetéséről, az európai gyakorlattal történő harmonizációról, a kreditek sokoldalú alkalmazásáról szólt. Az új évezredben erősen felgyorsította ezt a folyamatot a Bolognarendszerű képzésre való áttérés és ezzel párhuzamosan - illetve már az előző évtizedben is - a hallgatói mobilitás expanziója.

Ez a tanulmány ugyan egy fejezet erejéig kitér a kreditrendszerek elméleti alapvetésére, azonban nem az a célja, hogy a könyvtárnyi szakirodalmat még egy művel gyarapítsa. Az Európában 2014ben kezdődő újabb hét éves stratégiai ciklus új célokat fogalmaz meg a felsőoktatás területén is. A mobilitás továbbra is a prioritások között marad, azonban a nemzetköziesedés átfogó céljának egyik megvalósítási eszközeként új, globális támogatási programok eleme lesz, földrajzilag is kiterjedtebbé válik. Ezáltal a kreditrendszerek jelentősége is megnő. Azok az országok kerülnek előnybe, ahol a nemzeti szabályozás és annak alkalmazása rugalmasan alkalmazkodni képes a nemzetközi színtéren kialakuló legjobb gyakorlatokhoz.

Ez a tanulmány tehát az Európában eddig kialakult helyzetet mutatja be a legutóbbi fejlemények tükrében, majd áttér a nem európai gyakorlatok áttekintésére. Láthatóvá válnak a kreditrendszerek különbségei és kitérünk azokra a projektekre, amelyek a harmonizáció legjobb példái. Mivel az új Erasmus+ programban a mobilitás az európai felsőoktatási térséget a felsőoktatás globális terével összekapcsolva valósul meg, erre a váltásra fel kell készülnünk. A tanulmány ezt a felkészülést szolgálja.

Másrészt viszont a kreditrendszerek alkalmazásának vannak olyan procedurális elemei is, amelyek kevéssé függenek a mobilitás térbeli megvalósulásának helyszíneitől. A nemzeti szabályozásnak és a felsőoktatási intézmények gyakorlatának olyanná kell válnia, hogy a kreditelismerés, a kredit akkumuláció gördülékenyen, hatékonyan működhessen. Megnézzük, hogy a nemzetközi és a hazai gyakorlatban hol vannak a kreditrendszer működését akadályozó kritikus pontok. Javaslatokat dolgozunk ki ezek elhárítására: ez tanulmányunk másik fő célja.

A továbbiakban tehát a második fejezetben először a kreditrendszerhez kapcsolódó fogalmakat tekintjük át röviden, bemutatva a kredit fogalmának többféle értelmezését, a jelenlegi felfogásokat, a kredit funkcióit. Itt kerül sor a nemzeti és nemzetközi kreditrendszerek kialakulásának, a kreditrendszerek a felsőoktatási mobilitásban játszott szerepének rövid leírására, valamint a magyar kreditrendszer fejlődési állomásainak, jelenlegi helyzetének bemutatására.

A harmadik fejezet első része a kreditrendszer európai alkalmazásáról szól. Leírja az ECTS nemzetközi mobilitásban játszott szerepét, egyes országok eltérő gyakorlatát és a harmonizációra törekvést, az európai mobilitások alapjául szolgáló kreditegyezmény keretet. A fejezet másik része a felsőoktatás globális terében tárgyalja a nemzetközi szintű kreditrendszereket, majd az európai kreditelfogadási gyakorlatot segítő néhány kiemelt projektet mutat be röviden.

A negyedik fejezet a tanulmány egyik központi fejezeteként nemzetközi és magyar felmérések alapján áttér a kreditelfogadás nemzetközi gyakorlatának problémáira, majd a magyar kreditelfogadás helyzetére, a jó gyakorlatokra.

A rövid ötödik fejezet néhány bekezdést szentel az eddig Európából kezdeményezett, de Európán túlnyúló mobilitások környezetére (pl. Tempus, Erasmus Mundus, Atlantis, Alfa), majd kitér a nemzetközi szervezetek szintjén a tanulmányok kölcsönös elfogadására irányuló kezdeményezésekre, illetve a kreditelfogadás megkönnyítésére szolgáló földrészek közötti projektek közül ismerteti a legjelentősebb 
hatásúakat. Ezután a 2014-től megváltozó európai uniós gondolkodásmódot mutatja be, az Erasmus + program célkitűzéseivel.

Az utolsó, hatodik fejezetben javaslatokat fogalmazunk meg az országos szintű szabályozás egyes elemeinek fejlesztésére, kreditegyezmény-rendszer kidolgozására, illetve a magyar felsőoktatási intézmények nemzetközi mobilitásokban alkalmazott kreditelfogadási gyakorlata kapcsán az egységesítés irányában történő elmozdulás módozataira.

\section{Fogalmak: áttekintés. Kreditrendszer Magyarországon}

\subsection{A kredit meghatározása}

A felsőoktatás céljai között mindig szerepelt valamilyen módon a diákok tapasztalatszerzése, ismerkedése az anyaintézményen kívüli világgal, a tudásanyag szélesítése, mélyítése. A modern korban az országokon belüli és a nemzetközi hallgatói mobilitás szolgál ennek az igénynek a kielégítésére. Minél nagyobb számban mozognak a diákok, minél szervezettebbé válik vándorlásuk, annál inkább szükség van arra, hogy megfelelő eszközökkel segíteni lehessen a különböző helyeken szerzett tudások integrálását.

A kredit olyan eszközként jelent meg, amelyik nem csak a mobilitás során szerzett tudás elismerésére, hanem egyéb célokra, például a korábban szerzett tudás beszámítására vagy tapasztalati úton szerzett ismeretek elismerésére is szolgál. Több, hasonló definíciót is adhatunk a kreditre. Nem akarunk ugyan elmerülni a részletekben, ám érdemes több meghatározást is megnézni és egy kicsit elidőzni a különbségeknél - annál is inkább, mert a legtöbb esetben ezeknek a részleteknek az értelmezésbeli különbségei vezethetnek az eltérő elismerési gyakorlatokhoz.

15 európai ország közös projektjében, amely a tananyagtervezéssel, harmonizációval, határokon átnyúló felsőoktatással foglalkozott (Tuning 2005) a fogalom a következőképpen jelenik meg:

„A kredit a hallgatói munkaterhelést azzal az eszmei időráfordítással méri, amely meghatározott tanulási eredmények eléréséhez szükséges.”

Ennek a rövid, elvontnak tűnő meghatározásnak három fő eleme van. A kredit „hallgatói munkaterhelést” mér. Ez európai sajátosság. A hallgatónak az osztályteremben eltöltött ideje mellett magában foglalja a tananyag elsajátításához szükséges tanórán kívüli időráfordítását is. A végeredmény ugyan órában kifejezhető, ám két okból is „eszmei időráfordításhoz” vezet. Egyrészt meg kell határozni és órákra lefordítva mérni kell azokat a tevékenységeket, amelyek a tanulási folyamatban előfordulnak, másrészt pedig ki kell szűrni belőle az egyedi eltéréseket (minden diák más), vagyis az „átlagos diák” absztrakciója révén a pontos meghatározás helyett egy becsült munkamennyiséghez jutunk. Ennek a munkaráfordításnak azonban „megfelelő tanulási eredmény” eléréséhez kell kötődnie. Ezáltal eredmény-orientált (ha nincs igazolt tanulási eredmény, nincs kredit), másrészt pedig tanulmányi programhoz és annak megtervezőjéhez kötött.

Az általunk az európai gyakorlatban használt ECTS (European Credit Transfer System) kézikönyve (ECTS Guide 2009) is ezt a meghatározást teszi magáévá, kifejtve a tanulási eredmény fogalmát is:

„Az ECTS kreditek azon a munkamennyiségen alapulnak, amelyet a hallgatónak a várható tanulási eredmény eléréséhez teljesítenie kell.

A tanulási eredmények azt írják le, hogy a tanulótól mit várunk el a tudás, a megértés és a készségek szintjén, miután sikeresen befejezte a tanulási folyamatot. 
A munkamennyiség azt az időráfordítást mutatja, amire a hallgatónak a várható tanulási eredmény eléréséhez az összes tanulási tevékenység elvégzésével (mint például az előadások, szemináriumok, projektmunkák, szakmai gyakorlatok, önálló tanulás és a vizsgázás) tipikus esetben szüksége van.”

Magyarországon az Országos Kredittanács honlapján a fogalmi meghatározások között a kredit az alábbiak szerint szerepel: „A kredit a tanulmányi kötelezettségek teljesítésére irányuló hallgatói tanulmányi munka mértékegysége, az összes hallgatói tanulmányi munkaidővel arányos relatív mérőszám; nemzetközi konvenciónak megfelelően egy kredithez harminc munkaórát rendelnek.”

Derényi András tanulmányában (Derényi 2006): „A hallgatói tanulmányok elismerésének alapegysége a kredit, amely a hallgatók befektetett munkájának mennyiségét órában kifejező általános egyenértékes."

Az OKT által meghatározott 30 munkaóra elnevezése nála a „kredittarifa”.

Ehhez a némileg szofisztikált kreditfogalomhoz képest pragmatikusabb hozzáállást tükröz azon országok gyakorlata (pl. USA), ahol a kredit a hallgatónak az osztályteremben eltöltött idejével (kontakt óra) arányos.

Bárhogyan is határozzuk meg a kreditet, sokféle funkció betöltésére képes. Ahogyan azt egy korábbi tanulmányomban kifejtem (Temesi 2007), a kredit nem csak arra szolgálhat, hogy egy adott hallgató adott tanulmányi programban elért tanulási eredménye elérését számszerűen kifejezze, vagyis nem kizárólag számszerüsitési tulajdonsággal bír. Maga a tanulmányi program (annak részei és összessége, valamint a belső arányok) is kifejezhetők kreditben: ez a hozzárendelési (allokációs) tulajdonság.

Visszatérve a hallgatóra, kreditben mérhető az ő tanulmányi programban történő előrehaladása is. A kreditszámlálás Európában abból a megközelítésből történik, hogy 60 kredit felel meg egy átlagos európai teljes tanulmányi évnek. Egyre több tantárgy elvégzésével (a formális tanulásban), egyre több tanulási eredmény elsajátításával (akár a nem-formális vagy informális tanulás révén) mérni tudjuk az előrehaladást, illetve felhalmozódnak (akkumulálódnak) a kreditek valamely képesítés eléréséhez. Egy tipikus első- vagy második ciklusbeli képesítés eléréséhez 180-210, illetve 90-120 kreditet kell teljesíteni, s ez a szemeszteres rendszerben 6-7, illetve 3-4 félévig tart.

A kredit számunkra leglényegesebb tulajdonsága, hogy alkalmassá válik a hallgatói mobilitás során szerzett ismeretek anyaintézménybeli elismerésére. Ha különböznek is a nemzeti elvek a kredit számszerüsítésében, megnyílt az út az átszámitás és ezáltal a máshová történő kreditátvitel előtt. Az Európai Felsőoktatási Térben javasolt módszer az ECTS alkalmazása, ahol a T éppen a transzfert jelenti. Az átvitel természetszerűen hozza magával az elismerés lehetőségét.

Lényeges a kreditek és a minőségbiztosítási mechanizmusok összekapcsolása. Mivel a kredit a tanulás elvárt eredményéhez köthető, ezért az oktatási/tanulási módszerekre vonatkozó értékelési kritériumok pontos meghatározásának rendkívüli jelentősége van bármely kreditrendszerben. A minőség megőrzésének szempontjából igen fontos e két elem összefüggésének vizsgálata és kifejezésre juttatása (ez egyben a kreditelismerés alapja). A kreditek tehát ilyen értelemben nem csupán a tanulás mennyiségének puszta megállapítására szolgálnak, hanem minőséget is jelentenek. A kreditek minősége iránti nemzetközi bizalom csak akkor erősödhet, ha a nemzeti minőségbiztosítási mechanizmusok szigorúak, nyitottak, átláthatóak és hatékonyak.

Utoljára hagytunk egy olyan tulajdonságot, ami azonban már az ECTS definícióban is megjelent. A két- majd háromciklusú Bologna-típusú felsőoktatási rendszer újabb dimenziót ad a krediteknek: azt is tudnunk kell, hogy egy adott kreditmennyiség a képzés melyik ciklusából származik. A „kreditszintek”a tanulás összetettségéről, kreativitásáról, főbb jellemzőiről és mélységéről nyújtanak információt. A képesítési keretrendszerek szintleírásai általános útmutatást adnak a tanulás azon jellemzőiről, amelyek az egyes szinteken számbavételre kerülnek (OKKR 2011). 


\subsection{A Tuning megközelítés}

Az ECTS rendszer gyökerei az 1990-es évekre nyúlnak vissza. A kezdeti kísérletek után igazi lendületet az Európai Felsőoktatási Tér kialakításakor kapott. A Bologna-folyamatban kulcsszerepet játszó elméleti indíttatású projektek közül a legnagyobb hatású a Tuning projekt lett. Ez az oktatásfejlesztési program 2000-ben egy átfogó kutatással indult, amelyben felsőoktatási kutatók, szakértők arra keresték a választ, hogy milyen munkaadói, alkalmazói elvárások fogalmazódnak meg a felsőoktatásból kilépők irányába. Ez a kutatás egyben az európai felsőoktatás megújítását célzó Bologna-folyamat egyik megalapozó elméleti programjává vált.

A TUNING projekt indításakor a képesítések jobb megértése és összehasonlíthatósága céljából közös referenciapontokat tartalmazó tananyagfejlesztési koncepciót dolgoztak ki. Ennek öt lényegi aspektusa van (Tuning 2005):

- általános kompetenciák meghatározása,

- területspecifikus kompetenciák meghatározása,

- az ECTS kreditakkumulációs szerepe,

- a tanulás, tanítás, értékelés megközelítése,

- a minőségfejlesztés szerepe az oktatási folyamatban.

A projekt az első fázisban az első három elemre koncentrált, majd a későbbi második fázisban a negyedik és ötödik elem kapott nagyobb hangsúlyt. Kidolgozták a tananyagfejlesztés tervezésének, bevezetésének és a folyamatos monitoring tevékenységnek azt a modelljét, amelyet egyedi intézményi programok, vagy közös programok kidolgozásánál követni ajánlottak. A Tuning 1. és 2. szakaszában az évezred első évtizedének közepére kilenc szakterületre dolgoztak ki specifikus leírásokat. Ebben az időszakban nagyon sok intézmény és egyéni szakértő dolgozott a projektben, ekkor vált ismertté és elismertté. Mára már 20 fölött van azoknak a szakterületi leírásoknak a száma, amelyek a Tuning módszertanát alkalmazzák. A program és az eredeti projektben résztvevő szakemberek sok új projektben vettek részt és a Tuning honlapon található dokumentumok és linkek azt jelzik, hogy mindezek beépültek a Tuning történetébe.

Az egyik legfontosabb módszertani „folytatás” a Competencies in Education and Recognition (CoRe 2010) projekt, amely szintén két lépcsőben zajlott 2005 és 2010 között. A képesítési profilok kidolgozására szolgáló általános útmutató kidolgozását ez a projekt 2010 végén fejezte be. Itt azért nem térünk ki rá, mert elsősorban teljes képesítések elismerésével foglalkozik és a keretrendszeren keresztül a nemzetközi foglalkoztathatóság van a középpontban, jelen tanulmányunk viszont a tantárgyak, modulok és részprogramok elismerésére koncentrál, a nemzetközi mobilitással a középpontban.

A Tuning módszertan elkezdte hódító útját más kontinenseken is. Az ALFA Tuning Latin America program 2004 és 2007 között futott le és nagyfokú érdeklődéssel kísérték azt a dél-amerikai országokban. A program a következő években önálló intézményi és konzorciális kezdeményezések révén élt tovább, majd 2011-ben újra elindult egy 2013-ig tervezett intézményes projekt „oktatási és társadalmi innováció” alcímmel. A Tuning Africa, Tuning Australia és Tuning Canada projektek 20102011-ben az előkészítés fázisában voltak. 2010-ben Bilbaóban, 2011-ben Groningenben nyílt Tuning Akadémia. Ezt a sort folytatja a Tuning Russia projekt, amelyet a Tempus finanszíroz. Az orosz felsőoktatásban is kijelöltek kilenc olyan területet (közgazdaságtani és üzleti képzés, jog, ökológia, neveléstudomány, mérnöki képzés, információtechnológia, nyelvek, turizmus és szociális munka), ahol a Tuning módszertant alkalmazni kívánják. Egyes egyetemeken Tuning központokat is létrehoznak.

A nemzetközi harmonizációt célul kitűző tanulmányi programok fejlesztésében központi szerepe van az ECTS-nek: ezáltal a Tuning lett az ECTS egyik legfontosabb felhasználója, hordozója és egy- 
ben továbbfejlesztője. Hogyan gondolkodik a Tuning a kreditrendszerről? A (Tuning 2005) a Bolognaciklusokkal együttes tárgyalásban így határozza meg az alapelveket:

- A tanulást nem az időráfordítással, hanem a tanulás eredményességéhez kötődő kreditekkel kell meghatározni.

- Európának egy egységes kreditkeretről kell megállapodnia: az ECTS (Európai kredit-átviteli és akkumulációs rendszer) az egyetlen Európa szerte tesztelt kreditrendszer.

- Az első és a második ciklusbeli fokozatokat önmagukban értékkel bíró, önálló egységekként kell kezelni.

- Minden egyes képesítést a tanulás eredményességének és a megszerzett képességeknek a függvényében kell meghatározni.

- Ugyanazon típusú képzési programok esetében az első és a második képzési szinten megszerzett fokozatoknak egész Európában összehasonlíthatóvá kell válniuk a tanulás eredményességét és a megszerzett képességeket/készségeket tekintve. Nyilvánvaló, hogy milyen nagy jelentősége van egy szintjelző rendszernek e tekintetben.

- A képesítési követelmények teljesítéséhez szükséges idő tekintetében bizonyos rugalmasságnak kell jellemeznie a tanulás eredményességét és a megszerzett képességeket kifejező fokozatokat.

- Jóllehet a fokozatszerzés alapját a tanulás eredményessége jelenti, az összehasonlíthatóság szempontjából az időtényező sem mellőzhető teljesen. Ezért az első ciklus hossza 180 és 240 kredit között legyen. A második ciklus hossza 90 és 120 kredit közötti skálán határozandó meg. Ezen értékek a megfelelő tanulmányi eredményességhez, valamint a szintjelzőkhöz/szakmodellekhez kapcsolódnak.

- Egy átlagos nappali szak 60 ECTS kredit/tanév hivatalos terhelést jelent. A krediteknek az eszmei tanulási időt kell kifejezniük, ami a tanuló által a meghatározott követelmények teljesítésére és ezzel a sikeres kreditszerzésre fordított átlagos óraszámot jelenti. Ez a 60 pont a viszonyítási alap az élethossziglani tanulás (beleértve a munkához kapcsolódó és a nem iskolarendszerű formákat is) és az informális tanulás (élettapasztalat), valamint az önálló kurzusok (pl. az élethossziglani tanulás részei) szempontjából.

- Az első szinten elért kreditpontok száma nem kapcsolható össze a második szinttel a második szint, illetve a posztgraduális fokozat követelményeinek meghatározása céljából, mivel a két szint a képzettség szempontjából is - teljesen elkülönítendő a Bologna Nyilatkozat értelmében.

- Elvileg egész Európában lehetőséget kell biztosítani a belépésre a második szintű programba ugyanazon intézménytípusban szerzett első fokozat alapján, további követelmények meghatározása nélkül. Természetesen ebben az esetben a második fokozat logikusan következik az elsőből. A tényleges befogadás a második szintű fokozatot kínáló intézmény felelőssége.

Jól látható - és a közös fejlesztői gárda miatt nem véletlen -, ahogyan a legfontosabb európai kezdeményezések: Bologna-ciklusú képzés, Tuning típusú oktatásfejlesztés, európai kreditátviteli rendszer, Európai Képesítési Keretrendszer összefüggenek egymással.

A víziót is jól megfogalmazzák a Tuning dokumentumok:

„Nyilvánvalóan egyetlen, világos szabályokkal rendelkező európai kredit akkumulációs és átviteli rendszerre van szükség. Az egységes európai felsőoktatási tér azt igényli, hogy jöjjön létre Európában konszenzus egy olyan egységes kreditrendszerről, amely egyaránt alkalmas a transzfer és az akkumuláció céljára. Az ECTS ilyen rendszer.”

„Az ECTS-t átfogó, pán-európai kredit akkumulációs és átviteli rendszerré kell fejleszteni. Az ECTS, mint összeurópai akkumulációs és átviteli rendszer, fontos eszköze más, rugalmasabb felsőoktatási formák kifejlesztésének: részidős tanulmányok, ismétlődő tanulmányi szakaszok (élethossziglani tanulás). 
Az európai akkumulációs és átviteli rendszer kiépítéséhez ki kell alakítani a szintjelző rendszert és a modell-szakok rendszerét."

„Amint az ECTS-t elfogadják nemzeti szinten hivatalos akkumulációs és átviteli rendszerként, a kreditek elveszítik relatív értéküket és csak abszolút értékük lesz majd.”

A nemzeti rendszerek a Bologna-folyamat kapcsán nagymértékben közeledtek egymáshoz, ám még mindig nem egységes a rendszer. Az elvek elfogadásával és a jelenlegi konvergencia-folyamatban (amelyet az Európai Bizottság kétévenkénti jelentéseiben monitoroznak) a mobilitások kezelése - legalábbis elvben - egyre egyszerűbbé válik. Hogy ez a valóságban mennyire van így, erre a 4. fejezetben fogunk visszatérni.

\subsection{Kreditrendszer - kreditelismerés Magyarországon}

Magyarországon gyakorlatilag a 200/2000 (XI.29.) Korm. rendelet a felsőfokú tanulmányi pontrendszer (kreditrendszer) bevezetéséről és az intézményi kreditrendszerek egységes nyilvántartásáról megjelenéséhez köthetjük a felsőoktatásban a kreditek általános és kötelező bevezetését. Mintegy 3-4 éves szakértői és minisztériumi munka előzte meg ezt a rendeletet, amit az is mutat, hogy az nem más, mint a 90/1998 (V.8.) azonos című Korm. rendelet átdolgozása, A kreditek ECTS-kompatibilisek (a magyar kreditfogalom is hallgatói tanulmányi munkamennyiségen alapul, amely a tanórákat és az egyéni hallgatói munkaráfordítást egyaránt tartalmazza), és a rendelet részletesen leírja a kreditátvitel, a kredit-egyenértékűség, kreditakkumuláció fogalmait, alkalmazását. A pontosított jogi kereteket a 79/2006. (IV.5.) Korm. rendeletet a felsőoktatásról szóló 2005. évi CXXXIX. törvény egyes rendelkezéseinek végrehajtásáról adta meg.

A 79/2006-os kreditrendelet a 2005-ös felsőoktatási törvénynek a kreditelismerés szempontjából legfontosabb szakaszát bontja ki:

„Egy adott ismeretanyag elsajátításáért egy alkalommal adható kredit. A kredittel elismert tanulmányi teljesítményt - ha annak előfeltétele fennáll - bármelyik felsőoktatási intézményben folytatott tanulmányok során el kell ismerni, függetlenül attól, hogy milyen felsőoktatási intézményben, milyen képzési szinten folytatott tanulmányok során szerezték azt. Az elismerés - tantárgyi program alapján - kizárólag a kredit megállapításának alapjául szolgáló ismeretek összevetésével történik. El kell ismerni a kreditet, ha az összevetett ismeretek legalább hetvenöt százalékban megegyeznek. Az ismeretanyag összevetését a felsőoktatási intézmény e célra létrehozott bizottsága, a kreditátviteli bizottság végzi. A kreditátviteli bizottság a korábbi tanulmányokat és munkatapasztalatokat tanulmányi követelmény teljesítéseként elismerheti. A munkatapasztalat alapján beszámítható kreditek száma legfeljebb harminc lehet."

A felsőoktatási törvények (amelyek a hivatkozott rendeleteket is életre hívták) az Országos Kredittanácsot bízták meg tanácsadási és elemzési feladatokkal (Kreditlap 2013). Az intézményekben kreditátviteli bizottságokat kezdtek működtetni. A 2005-ös felsőoktatási törvény módosítása ezen bizottságok hatáskörébe utalta a korábbi tanulmányok és munkatapasztalatok elismerését is.

Az Országos Kredittanács hosszú és eredményes működésének lenyomataként működött a www.kreditiroda.hu honlap, amely a Kredittanácsáltal szervezettkreditfórumokanyagait, aKredittanács által kezdeményezett kutatások eredményeit, fontosabb fogalmak magyarázatait, linkeket, javaslatokat és ajánlásokat tartalmazott. Tanulmányunkban két jelentős akcióra térünk ki a későbbiekben. Az egyik a 2005-2006-ban lebonyolított és publikált kreditmonitoring projekt. A másik a Kredittanács javaslata a kreditelismerésről. A Kredittanács a 2011-es új felsőoktatási törvényben már nem jelent meg, működését 2012 januárjával beszüntette. 


\section{A kreditrendszer alkalmazása Európában és a nemzetköziesedő felsőoktatás globális terében}

\subsection{ECTS és ECTS-kompatibilis rendszerek Európában}

A kreditrendszer alkalmazását tanulmányunkban leszűkítettük a kreditelismeréssel kapcsolatos kérdéskörre. Az eddigiekben vázolt munkamennyiségen és tanulási eredményeken alapuló „európai” típusú megközelítést a Bologna-rendszerű képzések bevezetése óta egyértelműen az ECTS képviseli. A Bologna-aláíró országok minisztereinek kétévente megrendezett találkozóin a fejlődést mérő egyik indikátor az ECTS implementálása a nemzeti törvénykezésben és gyakorlatban. A legutóbbi Bolognajelentés (Bologna 2012) a 2012-es helyzetet az 1. ábrán mutatja be.

\section{1. ábra:Az ECTS használata a nemzeti kreditrendszerekben}

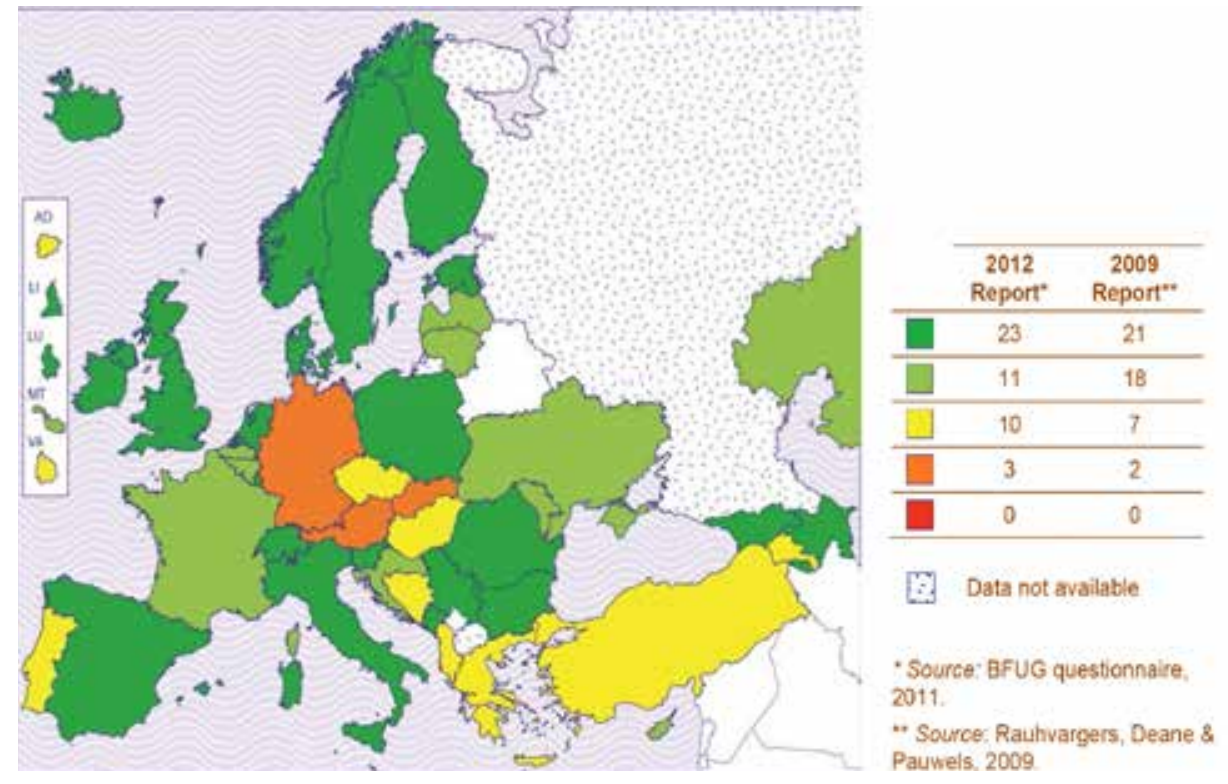

A színek erősségi sorrendet mutatnak.

- A sötétzölddel jelölt országokban az ECTS kreditek minden felsőoktatási programra kiterjedően adottak, ezzel lehetővé téve a transzfert és az akkumulációt egyaránt. A kreditek tényleges összefüggésben vannak a tanulási eredményekkel.

- A világoszölddel színezett országokban a programoknak legalább 75\%-ában használják az ECTS kreditet és azok tényleges összefüggésben vannak a tanulási eredményekkel VAGY az országban az ECTS rendszerrel teljes mértékben kompatibilis kreditrendszer van használatban tényleges öszszefüggésben a tanulási eredményekkel. 
- A sárga szín estében a programok 50-75\%-ára igaz, hogy minden komponense meg van adva tanulási eredményekkel összefüggö ECTS kreditben VAGY legalább 75\%-ban adottak a programelemek ECTS kreditjei, de még nincs meg a tényleges összekötés a tanulási eredményekkel (ide tartozik Magyarország).

- A világosabb pirossal jelölt esetben 50\% alatt van az ECTS-használat VAGY az ECTS kreditekkel nem teljesen kompatibilis nemzeti rendszer van érvényben.

- Végül a piros szín azt jelentené, hogy mintegy 50\%-ban használatos az ECTS VAGY használják ugyan az ECTS-t, de nem kredit transzferre - de ilyen ország már nincs.

Mivel a kreditelismerési eljáráshoz világos szabályoknak kell tartozniuk, az ECTS kialakítása során több eszközt is kifejlesztettek, amelyek a hallgatók tanulmányainak egyeztetését, az elért eredmények megismerését, a kreditek elismerését segítik elő. A részletekkel az intézményeket és a hallgatókat az ECTS Útmutató ismerteti meg, ahol a fogalmakon és eljárásokon túl fontos dokumentumokat is találunk. Ilyen a Tanulmányi Megállapodás (Learning Agreement) és az Eredményközlő Lap (Transcript of Records). A megállapodást a cserében résztvevő két intézmény koordinátorai és a hallgató írja alá és az egyik legfontosabb dokumentum. Kitöltésének hiányosságai nagymértékben hozzájárulhatnak az elismerési problémák létrejöttéhez. Az eredményközlő lap tanúsítja, hogy ténylegesen mit és milyen eredménnyel végzett el a hallgató külföldi tanulmányai alatt. Ez a dokumentum a konkrét elismerés alapja, eszerint ismeri el az anyaintézmény és írja jóvá a megszerzett krediteket, osztályzatokat.

Európa tehát a tisztán ECTS-t felhasználó vagy teljesen ECTS-kompatibilis nemzeti rendszerek felé halad.

Míg a Tuning program szakértői egy összeurópai kreditrendszerben látták az egységesség megoldását, s ezt az ECTS-kreditrendszer univerzális elterjesztésével vélték megvalósítani, az utóbbi években az angol példával illusztrálható nemzeti képesítési és kredit keretrendszer megközelítés jelent meg életerős alternatívaként.

Az angol kreditkeretben (Credit Framework 2008) kreditet akkor kap a hallgató, ha a megfelelő tanulási eredményt egy meghatározott szinten elérte. A kredit jellemzői a kreditszint és a kreditszám. A kreditszint a tanulmányok komplexitásának, követelményeinek és/vagy mélységének, valamint a tanuló autonómiájának relatív indikátora. Egy tanulmányi csomaghoz, meghatározott szinten, úgy rendelünk kreditszámot, hogy az kifejezze a becsült eszmei tanulási óraszámot: 1 kreditnek 10 eszmei tanóra felel meg.

Az egész Egyesült Királyságra kiterjedő ajánlás végső formát 2008-ban öltött és a bevezetést is ütemezte. A szigetország jó példa arra, hogyan lehet röviden, tisztán formába önteni a fogalmakat és egyben utat mutatni az alkalmazásra. A dokumentum elkészítését a képesítési keretrendszer bevezetése motiválta. Miközben maga a kredit mintegy 25 évvel ezelőtt vonult be az Egyesült Királyság felsőoktatásának gyakorlatába, a mérési-számszerűsítési elvek eltérőek voltak az egyes nemzeti keretek között. Párhuzamosan, ám azonos elvek mentén fejlesztették ki a kontinensen az ECTS kreditet. A mindennapi gyakorlatban 2 UK kredit1ECTS kreditnek feleltethető meg.

A kifejlesztett képesítési keretrendszerben egyszerre jelenik meg a kredit szintje és száma és együtt jellemzik a képesítést. Praktikusan ez azt jelenti, hogy önmagában az nem mond semmit, ha egy tanuló 60 kredittel rendelkezik, mindaddig, míg hozzá nem tesszük, hogy ez a kredit hányadik szinten keletkezett. Az angol fokozatok rendszere eléggé bonyolult, 19 felsőoktatási végzettséget soroltak be az EKKR 5 szintjére. Mivel tehát a képesítési keretrendszerbe történő beillesztést is elvégezték már, ezért egy végzettség megadásával automatikusan a szint is adódik.

A képesítési keretrendszer szintleírásai azért fontosak, mert segítségükkel olyan tanulási eredményeket is szintezni és kreditálni lehet, amelyek nem tartoznak bele a formális felsőoktatás 19 végzettségébe.

Az Európai Képesítési Keretrendszer megalkotása óta az ECTS még fontosabbá vált. Belátható, 
hogy ha egy ország felsőoktatása munkamennyiségen alapuló nemzeti kreditrendszerrel rendelkezik, s ebben a rendszerben minden képesítést tanulási eredményekkel írtak le, akkor egy átváltással bármely másik, hasonló felsőoktatással rendelkező országban szerzett képesítések összehasonlíthatóvá válnak, illetve a kreditek átszámolhatók. Az átváltás az Európai Képesítési Keretrendszeren és az ECTSkreditrendszeren keresztül történik.

Ha egy magyar cserehallgató tehát Angliában egy research master programban tanul, akkor az az angol keretrendszer \%. szintje. Ez ekvivalens a bolognai második ciklussal és az EKKR \%. szintjén van. Az ott szerzett 90 kreditet 45 ECTS kreditnek lehet megfeleltetni. Hazatértekor a hallgató a magyar képesítési keretrendszer megfelelő szintjén a 45 ECTS kreditnek megfelelő magyar kredittel rendelkezik (ebben az egyszerü példában ez 45), és kreditjeit pl. egy magyar mesterprogramban tudja elismertetni.

\section{2. Átfogó kreditrendszer kísérletek más kontinenseken}

\section{Ázsia}

Vessünk egy pillantást más kontinensekre is. A nem angolszász hagyományokkal rendelkező, jelentős fejlődést produkáló földrészek közül az ázsiai országok külügyminiszterei Thaiföldön 2002-ben 18 ország részvételével elindították azokat az együttműködési megbeszéléseket (Asia Cooperation Dialogue), amelyeknek \%. találkozóján 2008-ban Malajzia javaslatára megállapodás született egy ázsiai kreditátviteli rendszer önkéntes alapú kidolgozásáról. Az ACTS (Asian Credit Transfer System) ugyan nevében az európai kreditrendszerhez való hasonlóságra utal, ám sajátosságait a maláj minőségvédelmi ügynökség tapasztalataira alapozták. Az időközben megnövekedett taglétszámú találkozók kerekasztal megbeszélésekkel is kibővültek, és az ACTS fejleményeinek vizsgálata is napirendre került. Malajzia - mint kezdeményező és a 31 ország részvételével elindított Asia e-University (AeU) motorja - 2011 szeptemberében a 4. kerekasztal megbeszélésen előterjesztőként számolt be az ACTS állásáról (ACTS 2011) és javaslatokat tett a további teendőkre vonatkozóan.

31 ázsiai ország magas szintű kormányzati delegáltjai vállalták, hogy országaik részt vesznek a közös felsőoktatási kreditátviteli rendszer megvalósításában. Az országok között megtalálható többek között India, Irán, Korea, Oroszország, Pakisztán, Szaúd-Arábia, Szingapúr, Tajvan és Vietnám. Ausztrália az Európával történő mobilitásokban az ECTS használata mellett döntött. A rendszer célkitűzései erős hasonlóságot mutatnak az európai kreditátviteli rendszerrel, de fókusza először a távoktatásra irányult. A távoktatásban résztvevő hallgató számára lehetővé teszi, hogy megszerzett kreditjeit más országok megfelelő programjaiban elismerjék, s ezáltal nem kell kurzusokat ismételnie. Így felgyorsulhat a diploma megszerzésének folyamata és költségek is megtakaríthatók.

A távlati célokat illetően a rendszer teljes körűvé válik és mind a kreditátvitelt, mind a kreditakkumulációt támogatja. A közös átváltási szisztéma az akadémiai programok és a képesítések elismerésével könynyebbé teszi az ázsiai országok felsőoktatási mobilitását. Együttműködésre serkenti az ázsiai felsőoktatási intézményeket, elősegíti a közös programok tervezését és elfogadását, támogatja az előzetesen megszerzett tanulmányi eredmények elismerését és vonzóbbá teszi az ázsiai felsőoktatásban való részvételt más kontinensek hallgatói számára.

Az ACTS kreditfogalom az órában kifejezett hallgatói időráfordításra épül, amelynek két komponense a kontakt óra és az egyéni tanulás. A hallgatói időráfordítás azoknak az elismert hallgatói terhelési összetevőknek az időigénye, amelyeket a hallgatók különböző oktatási módszerek mellett (előadás, gyakorlat, laboratórium, stb.) különböző tanulási tevékenységekkel (házi dolgozatok, tantermi viták, praktikum, stb.) és számonkéréssel (írásos vagy szóbeli vizsga, szakmai gyakorlat beszámoló, projektfeladat, stb.) töltenek. 
Javaslat született egy ACTS Útmutató elkészítésére. Az ehhez szükséges ajánlások:

- egy kredit 40 óra névleges (átlagos) hallgatói időráfordítást jelentsen,

- a maximálisan átvihető kreditmennyiséget a program szintje határozza meg és intézményi döntésen múlik - de elérheti akár a 70\%-ot is,

- a minimálisan megszerzendő kredit alkalmazkodjon a programtípusokhoz:

Certificate Degree 60 kredit (2400 óra)

Diploma Degree 90 kredit (3600 óra)

Bachelor Degree 120 kredit (4800 óra)

- az értékelési skála egy lehetséges változatát is megadták, de természetesen a nemzeti sajátosságok ezt erősen befolyásolják,

- az alkalmazásnak ki kell terjednie az előzetesen megszerzett (informális és nem formális módon elsajátított) és a távoktatásban szerzett tanulási eredményekre is, elősegítve ezzel az élethosszig tartó tanulást.

Az ECTS európai benchmarkot felhasználva készülnek el az ACTS kézikönyv mellett a tanulmányi megállapodások, az eredményközlő adatlap és az előzetes tanulási eredmények elfogadásához szükséges nyomtatványok.

\section{Latin-Amerika}

A Tuning szakértői csoport 2013-ban jelentette meg a latin-amerikai referencia kreditről szóló ajánlását. A kidolgozásban 18 latin-amerikai ország mintegy százötven egyeteme vett részt. A gondolatmenet a következő.

Generikus és specifikus jellemzők szerint elkészülnek a képzési területenkénti tantervi profilok (a futó projektben 15 diszciplinában). Az így készült kompetencia-alapú tantervet összekapcsolják a reális hallgatói munkamennyiségekkel, ezáltal egy kölcsönös megfeleltetést létesítve a tanulási eredmények és a tanulói munkamennyiségek között. Megalkotják azt az oktatási és számonkérési környezetet, amelyben elérhetők a kitüzött tanulási eredmények.

Ezeket a lépéseket egy mérési (kalibrálási) szakasz követi, ahol a mért munkamennyiségekhez kreditet rendelnek.

Mint 2011-ben egy Latin Amerikát átfogó felmérés megállapította, a kontinens felsőoktatási intézményeinek nagy részében nem alkalmaznak kreditrendszert, vagy ahol ilyenek mégis léteznek, egymástól nagyon különbözőek. Uruguayban egy kredit 15 óra, Chilében (ahol alkalmazzák) egy kredit 25-30 óra, Mexikóban 15 elméleti óra 2 kredit, 15 gyakorlati óra egy kredit, Kolumbiában egy kredit 48 óra és itt az irányított és egyéni munkaórák kreditszámítása különböző, Brazíliában 15-20 elméleti óra, vagy 30-40 gyakorlati óra, vagy 60-80 önálló munkaóra jelent egy kreditet, és így tovább. Amennyiben a törvény meghatározza a minimális és maximális óraszámot egy félévre vonatkozóan, ebből kiszámolható az, hogy egy félévben hány kreditet kell a hallgatónak megszereznie - és ez nyilvánvalóan más és más lesz például Uruguayban és Brazíliában. A helyzetet - mint lájuk - bonyolítja, hogy Latin Amerikában nagyon alacsonyra értékelik az önálló tanulással töltött időt.

Mivel Latin-Amerika erősen érdekelt abban, hogy országai között és a kontinensen túl beinduljanak és megerősödjenek a hallgatói áramlások, ezért motiváltak abban (különösen a nemzetközileg is kiváló vagy arra törekvő intézmények), hogy kreditrendszert vezessenek be, ezzel segítve a mobilitást. Latin Amerikában azonban nem kizárólag technikai kérdésről van szó. Át kell alakítani a tanulásról vallott felfogást is, tanuló-központú oktatási formák felé fordítva a felsőoktatást. Ez a folyamat nem megy egyik napról a másikra, idő kell hozzá.

A fejlesztők a latin-amerikai egyetemekkel összefogva párhuzamosan szeretnék bevezetni és elter- 
jeszteni az új pedagógiai felfogást, a kompetencia-alapú tananyag tervezést és az ehhez kapcsolt munkamennyiség alapú kreditrendszert.

A latin-amerikai referencia kredit (CLAR) azon a munkamennyiségen alapul, amelyre a hallgatónak meghatározott tanulási eredmény elérésére és annak elsajátítása bizonyítására (vizsgával vagy adott tanulási időszak elvégzésével) szüksége van (CLAR 2013). A CLAR egy évnyi teljes idejű hallgatói munkaterhelést 60 kredittel ismer el.

A konkrét időbeosztás országonként eltérő lehet. Ha valahol egy tanév 36 hétből áll, ahol minden hétre 45 órát számolnak (amiben a kontakt órák, gyakorlatok, önálló munka mind benne van), akkor a teljes óraszám 1620, s ha ezt elosztjuk 60-nal, akkor azt kapjuk, hogy az adott országban egy kreditnek 27 munkaóra felel meg.

Mivel a felmérések szerint Latin-Amerikában egy tanév 32 és 40 hét között váltakozik, ezért a referencia kredithez 36 hetet rögzítettek. A becsült óraszámok hetente 40 és 55 között váltakoznak LatinAmerikában. Ezekkel számolva a 36 hetes referencia időszakra az éves óraszám 1440 és 1980 között van, vagyis a kredit időmennyisége 24 és 33 munkaóra között van. Mindezek az értékek a jelenlegi gyakorlatokat tekintve elvileg bármely ország számára elfogadhatóak.

\subsection{Jó gyakorlatokra koncentráló globális projektek}

Az Európából kiinduló más kontinensekre kiterjedő csereprogramok legtöbbje az Erasmus Mundus keretében zajlik. Az Unió olyan elemző projekteket is indít ezen a kezdeményezésen belül, amelyek a jó gyakorlatokat térképezik fel és elősegítik az együttműködést.

Az ASEMUNDUS projekt 2009-ben indult, a DAAD vezetésével, résztvevői Ausztria, Belgium, Ciprus, Észtország, Magyarország, Lettország, Hollandia és Lengyelország: minisztériumok, felsőoktatás-fejlesztési alapítványok, minőségbiztosítási szervezetek (ASEMUNDUS 2009). 2009-ben az Erasmus Mundus projekteknek csak 7,7\%-ában volt ázsiai partner. A projekt az ázsiai országok erőteljesebb bevonását célozta meg, három országgal a fókuszban: Indonézia, Korea és Thaiföld. A projekt a hálózati szemináriumok módszerét alkalmazta, azonban 2010-11-ben a térséget sújtó természeti katasztrófák miatt a tevékenység zöme áttolódott a 2012-es évre. Az európai partnerekkel együttes szemináriumokon az ázsiai résztvevők száma elérte a százat - ez aránylag magas érték, tekintve az ázsiai országok addigi alacsony reprezentációját. A három említett országon kívül japán, kínai és vietnámi ASEMUNDUS promóterek kezdték el tevékenységüket 2012-ben a szemináriumok után.

A három éves projekt lezárultával nem csak annak felsőoktatási, de politikai hatásait is értékelték. A közös programok a mesterképzésen kívül a doktori képzésben is megjelentek, magukkal hozva a kutatási együttműködéseket is. Továbbra is nagy hangsúlyt fektetnek a jó gyakorlatok megőrzésére és bemutatására.

A MIND és a LOTUS I-II-III projektekben 9 európai és 11 ázsiai országból nagy számú hallgatót mozgattak meg a két kontinens között közös mester- és doktori programokban az ipari ökológia témakörében.

Az ACCESS projekt célkitűzése az európai és dél-kelet ázsiai országok stratégiai együttműködésének erősítése a felsőoktatás területén (ACCESS 2010). Diagnózisa szerint többféle kezdeményezés született, amelyek motorja a dél-kelet ázsiai miniszteri találkozók által kezdeményezet EU-Ázsia találkozók rendszere, illetve az Európa-Ázsia Alapítvány, ám áttörést egyik kezdeményezés sem ért el. Ennek egyik fő okát az ACCESS jelentés abban látja, hogy az EU-Ázsia együttműködések magas szintű találkozóin a felsőoktatás nem kiemelt terület. Az is igaz, hogy a régió törékeny, politikailag instabil országai értelemszerűen nehezen tudnak felsőoktatási projektekbe bekapcsolódni. Az ACCESS által végzett hallgatói 
felmérés viszont kimutat mobilitási igényeket - azok (főleg pénzügyi) korlátaival együtt. A projekt javaslatai célzott akciókat tartalmaznak. Ezek részben a már meglévő kapcsolatokat tágítanák.

Ezekben a projektekben a kreditelismerés témaköre önmagában kevés alkalommal jelenik meg. Ennek oka az, hogy az Erasmus Mundus bilaterális és multilaterális intézményi kapcsolatai még nagyobb számosságú konzorciumok esetében is lehetővé teszik a közös tanterv kidolgozása során egyedi, automatikus elismerési sémák alkalmazását.

A JOIMAN (Joint Degree Management and Administration Network) projekt 15 egyetem konzorciumaként működött 2008 és 2010 között. Olyan közös diplomával végződő programokat vizsgáltak, ahol az egyik fél EU-EFTA tag, a másik nem (JOIMAN 2011). 94 programból 17-et vizsgáltak meg tüzetesebben. Ezek között finanszírozás szempontjából voltak Erasmus Mundus master programok (5), EU-US Atlantis programok (3), Tempusban kifejlesztett program (1) és egyéb, nem EU-finanszírozta programok (8). 11 programot nagyobb konzorciumok kínáltak, 6-ot kétoldalú kezdeményezés révén fejlesztettek ki.

A vizsgált programok rendkívül sokszínűek voltak abból a szempontból, hogy milyen előélettel rendelkeztek. Egyes esetekben egy régebbi együttműködés és cserekapcsolat „ért be”, más esetben új volt a partnerek közötti kapcsolat. Olyan is volt, amely két ország bilaterális egyezménye alapján valamely fontos ipari területet célzott meg. Európai szemszögből a programokban való részvétel motivációja legtöbbször a nemzetköziesítés erősítése (több nem-európai diák jelenléte az egyetemen) és ezzel együtt a program bevételképző szerepe volt. A nem-európai intézményekben a pénzügyi motiváció mellett megjelent a presztízs szempont is: az európai partnerek elismerést jelentettek az adott ország felsőoktatásában.

A projekt eredményeiből azokat emeljük ki, amelyek az eltérő kreditrendszerekkel, a kreditek alkalmazásával kapcsolatosak. A programok tervezésekor dönteni kellett arról, hogy mekkora legyen a mobilitási időtartam (amikor a hallgatók fizikailag is más intézményben tartózkodnak). Ez általában egykét szemeszter volt. Példák: az első szemeszter otthon, a második egy partnernél, majd a diplomamunka megírása és védése is a partnernél; első szemeszter egy európai intézményben, a második egy másik európai intézményben, a harmadik az Egyesült Államokban. Magától értetődően merült fel a kérdés: melyik ország kreditrendszerében számoljanak el?

A példák több jó gyakorlatot is bemutatnak. A lényeg mindenütt az alapos előkészítés és az írásos megegyezés. A hallgatóknak minden információt meg kell adni. Olyan esetekben, amikor a két ország gyakorlata nem állt messze egymástól és az ECTS koncepciótól, a közös megoldás az ECTS kredit használata volt. Ahol a partnerek egyike munkamennyiségben, a másik kontakt órákban szokott számolni, megegyeztek a konverzióban. Például az egyik double degree programban 1 US kreditnek 2 ECTS kredit felelt meg - a kalkuláció minden különösebb túlbonyolítása helyett. Egy sokszereplős programban abban egyeztek meg, hogy minden partner a saját rendszerében fogadja a hallgatókat és az átszámítás a küldő partnerek feladata (a hallgatók egyéni tanterveinek alapos értékelésével). Voltak olyan közös programokat finanszírozó projektek is, amelyek eleve kikötnek egy elszámoló kreditrendszert és ennek alkalmazása a közös tanterv kidolgozóinak feladata.

Mint a leírásokból kiviláglik, a közös programok oly sok buktatót rejtenek, hogy ezek többségében valamilyen pragmatikus kompromisszum a legbölcsebb megoldás. A kreditelszámolás és kreditelismerés ezekben az erősen szabályozott programokban nem szokott nehézséget okozni, s ha mégis problémák merülnének fel, az egymást jól ismerő partnerek ezeket hamar elsimítják.

Külön érdekessége volt a nagyobb (94 elemű) felmérésnek, hogy az egyik legérzékenyebb pont az osztályozási rendszerek különbözősége volt. Nem véletlen, hiszen ezt a kérdést az Európán belüli mobilitásoknál is csak nehezen tudják kezelni (lásd a PRIME hallgatói felmérés eredményeit). 


\section{A kreditelismerés gyakorlatának problé- mái a világban és Magyarországon}

\subsection{Az Erasmus Diákhálózat felmérése (2010)}

Az Erasmus Diákhálózat (Erasmus Student Network) kiemelt figyelemmel kíséri a diákmobilitás eredményességének egyik fő mutatóját, a külföldi tanulmányok elismerését. 2010-ben kiadott jelentésük (PPRIME, 2010) a második a sorban és a 2009-2010-es eredményeket dolgozza fel (az előző jelentés 2008-2009-ről szólt). A 25 évvel ezelőtt elindult Erasmus csereprogram a Bologna-folyamatnak is egyik „ékköve” lett. 1987-től 2010 közepéig 2.2 millió hallgató vett részt a cserékben. A mobilitás jelentősége nem változik, sőt éppenséggel nő: a 2020-ra vizionált érték ennek a számnak sokszorosa.

De vajon azokon a célokon túl, amelyek az európai identitás kibontakozását segítik, a kultúrák megismerésére, az együttélés mindennapjaira vonatkoznak, teljesülnek-e az akadémiai célkitűzések is? Igaz-e az, hogy a cserehallgató nem „veszít” félévet vagy tanévet? Sikerült-e a tanulmányok beszámítását, elismerését megfelelő adminisztratív eszközökkel is biztosítani? Ebben a kérdéskörben a kredit kulcsfogalom volt és az is maradt. Az ECTS és a vele együtt megjelent tanulmányi megállapodások mellé időközben felsorakoztak egyéb támogató eszközök is: a diplomamelléklet, az ösztöndíjak hordozhatósága vagy az Erasmus Charter, az ECTS Label megjelenése.

500 felsőoktatási intézmény mintegy 9000 hallgatója vett részt a felmérésben. A PRIME jelentések elődjének tekinthető Trend felmérésekben is megjelent a diákok és a tanulmányok elismerésének kérdésköre. Míg azonban a Trend riportok mintegy mellékesen és elsősorban az intézmények szemszögéből foglalkoztak a kérdéssel, az Erasmus hálózat vezetői úgy látták, ennél alaposabb elemzésre van szükség. A Trend V például úgy látta (Trends V, 2007), hogy bár vannak - akár jelentősnek is mondható - problémák a tanulmányok elismerésével, azok 2003 óta nem változtak és főleg jogi és pénzügyi okokra vezethetők vissza. A miniszteri találkozók jelentéseiben hasonló kijelentések fogalmazódtak meg.

Az Erasmus Hálózat 35 országban 370 felsőoktatási intézményben rendelkezvén szekciókkal elég erősnek érezte jelenlétét a nemzetközi diákmobilitásban ahhoz, hogy statisztikailag is megfelelő számosságú mintából levonható releváns következtetések érdekében önálló felméréseket indítson. A Problems of Recognition In Making Ersamus (PRIME) elnevezésű projekt eredményei ma ebben a tárgykörben a legmegbízhatóbbak és legtöbbet idézettek (bár a magyar felsőoktatási intézmények többségében keveset vagy egyáltalán nem hallottak erről a kutatásról).

Érdemes részleteiben is megismerkedni ezzel a fontos elemző anyaggal. A kutatás a következő főbb elemekre fókuszált:

- a küldő és fogadó intézmény által nyújtott információk,

- a tanulmányi megállapodás folyamata, aláírása,

- az ECTS használata és szerepe az elismerésben,

- osztályozási (értékelési) rendszerek, azok átvitele, konverziója,

- az Erasmus ösztöndíjak és egyéb pénzbeli támogatások, valamint azok hordozhatósága.

Témánk szempontjából a középső három elemnek van fontossága, az ezekre vonatkozó eredményekből mutatunk be néhányat. A kutatásban - amelyben a diákokon kívül a nemzeti ügynökségek és néhány egyetem is projektrésztvevő volt - külön kérdőíveket kaptak a diákok, a felsőoktatási intézmények és a nemzeti ügynökségek. Az utóbbiakkal interjúkat is lefolytattak. 48 ország diákjai válaszoltak a kérdő- 
ívekre. A többség $(96,4 \%)$ Erasmus cserehallgató volt, tapasztalataik nagy része (néhány specifikumot kivéve, pl. a megállapodások aláírása) azonban általánosítható, különösen akkor, ha az egyéb cserék is valamilyen intézményes keretben folytak (pl. CEEPUS, Basileus).

Az elemzésekben csak azok az országok szerepelnek, ahol a válaszolók létszáma megfelelően nagy, ezért végül a fö táblázatokban általában 27 ország szerepel 8500 fővel. Országonként eltérő lehet az is, hogy milyen a kiutazó és beérkező hallgatók aránya. Ez kevés országban kiegyensúlyozott. A minta 55,5\%-a első ciklusban és 37,8\%-a második ciklusban tanuló hallgató, 4,6\% tanul integrált képzésben. A 2. ábra mutatja be a képzési területek arányait a kiutazó hallgatók otthoni tanulmányaira vonatkoztatva. Látható, hogy a mérnöki, üzleti és közgazdasági területek az összes cserékből mintegy 30\%-ot képviselnek - ezeken a területeken a legmozgékonyabbak a hallgatók.

\section{2. ábra: Cserehallgatók megoszlása képzési területek szerint}

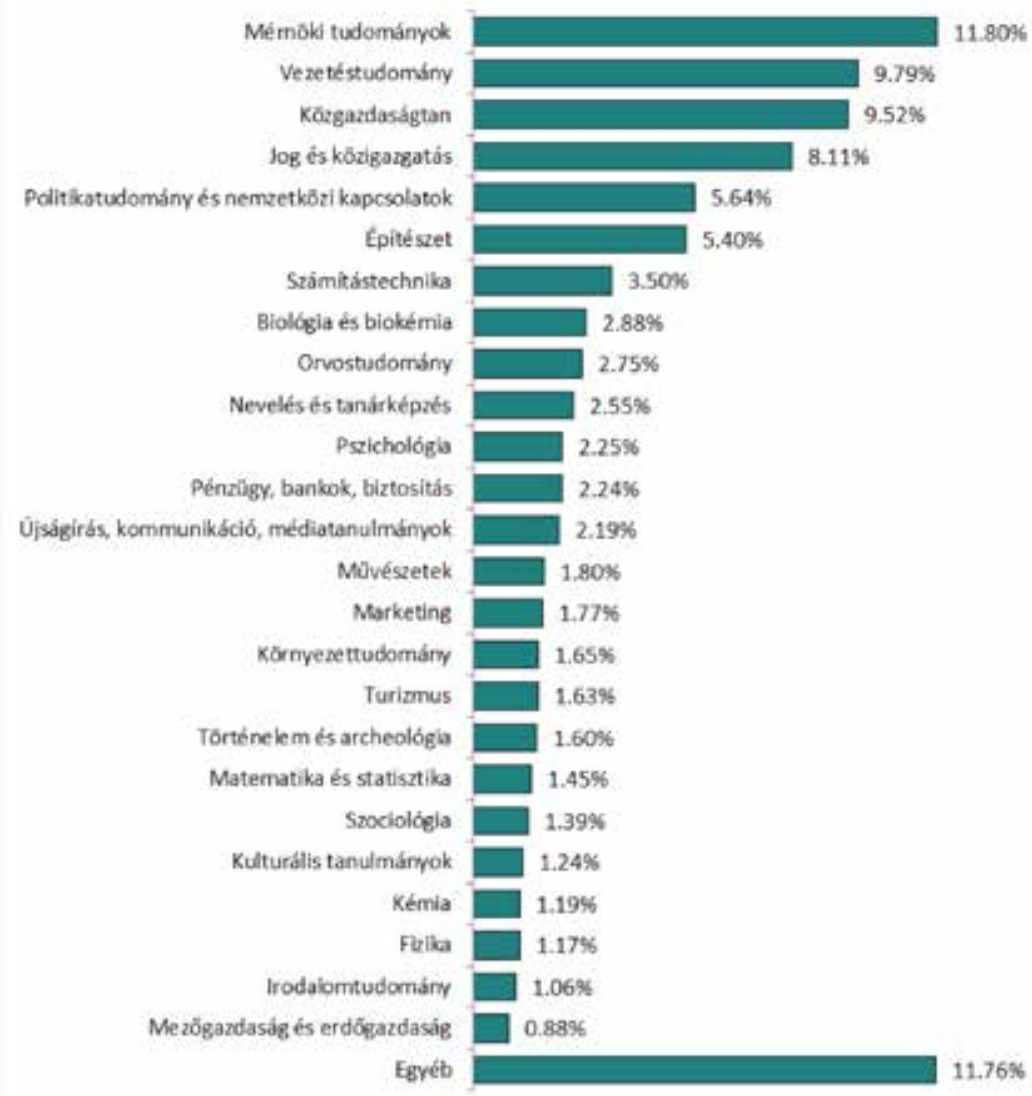

A cserében a hallgatók 18,7\%-a tanult az otthonitól eltérő képzési területen. $60 \%$ egy félévet, $38 \%$ két félévet töltött külföldön, míg 2\%-a válaszadóknak 3 hónapnál kevesebb ideig volt cserehallgató. 
Intézményi szinten 400-an válaszoltak a kérdőívre 31 országból (lásd a 3. ábrát).

3. ábra: Intézményi válaszolók aránya országok szerint

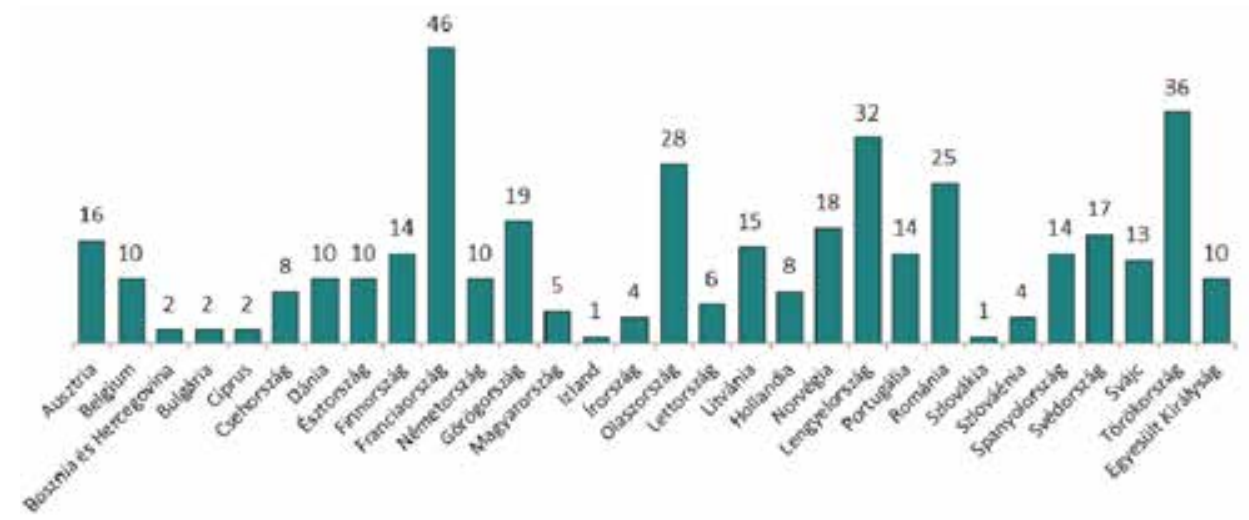

Elvileg mind a hallgatók, mind az intézmények esetében hatással kellett lennie az eredményekre az Erasmus Charter aláírásával vállalt kötelezettségeknek. A 4. ábra azt mutatja be, hogy az adott ország összes felsőoktatási intézményéből hány százalék írta alá ezt a fontos okmányt. Magyarországon 70 intézményből 53 rendelkezik érvényes szerződéssel (76\%). Látjuk, hogy Spanyolországban például 42\%, míg Finnországban vagy Görögországban $100 \%$ ez az arány.

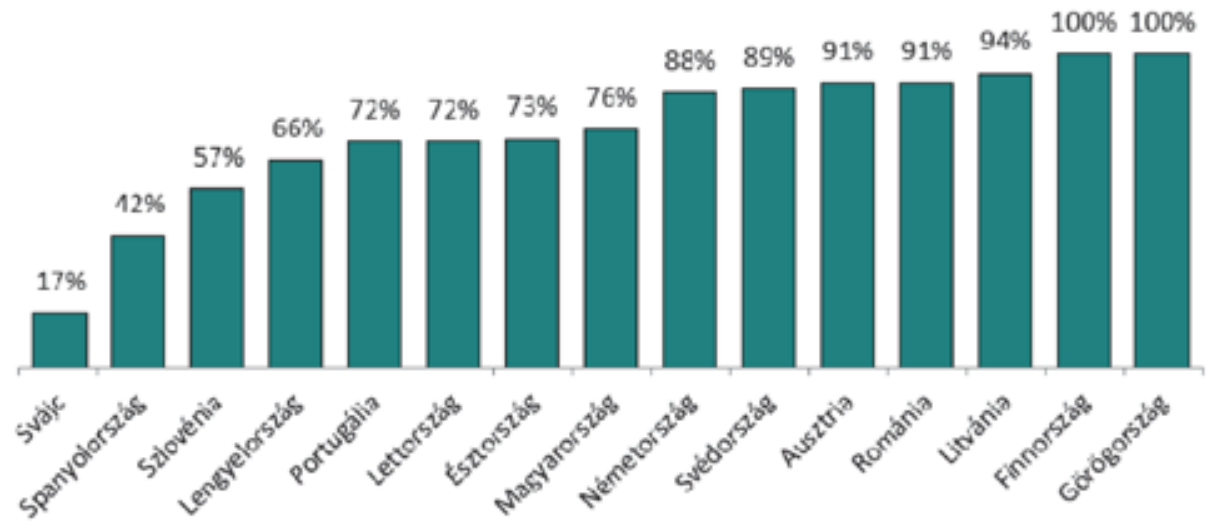

\section{4. ábra: Az Erasmus Charter aláíróinak aránya egyes országokban}

A továbbiakban a bemutatott adatok a mintára vonatkoznak. Milyen torzítások lehetségesek? A kérdőívekre nyilván nem mindenki válaszolt, hanem csak a legaktívabb hallgatók. Ahol van Erasmus szekciója a hálózatnak, ott általában többen válaszoltak. Az intézmények esetében is valószínű, hogy azok vonakodtak válaszolni, ahol éppen problémák lelhetők fel. A kérdőívek nyelve angol volt. Mindezek mellett - és más megbízható adatok hiányában - érdemes az eredményeket megnézni és ezek mentén gondolkodni a teendőkről, javaslatokról Magyarországon is. 
Honnan származnak a hallgatók információi az Erasmus különböző dimenzióiról? A nemzetközi irodákon és a kari vagy intézményi Erasmus koordinátorokon kívül a legfontosabb forrást a volt cserehallgatók jelentik (5. ábra).

\section{5. ábra: A hallgatói információk forrásai}

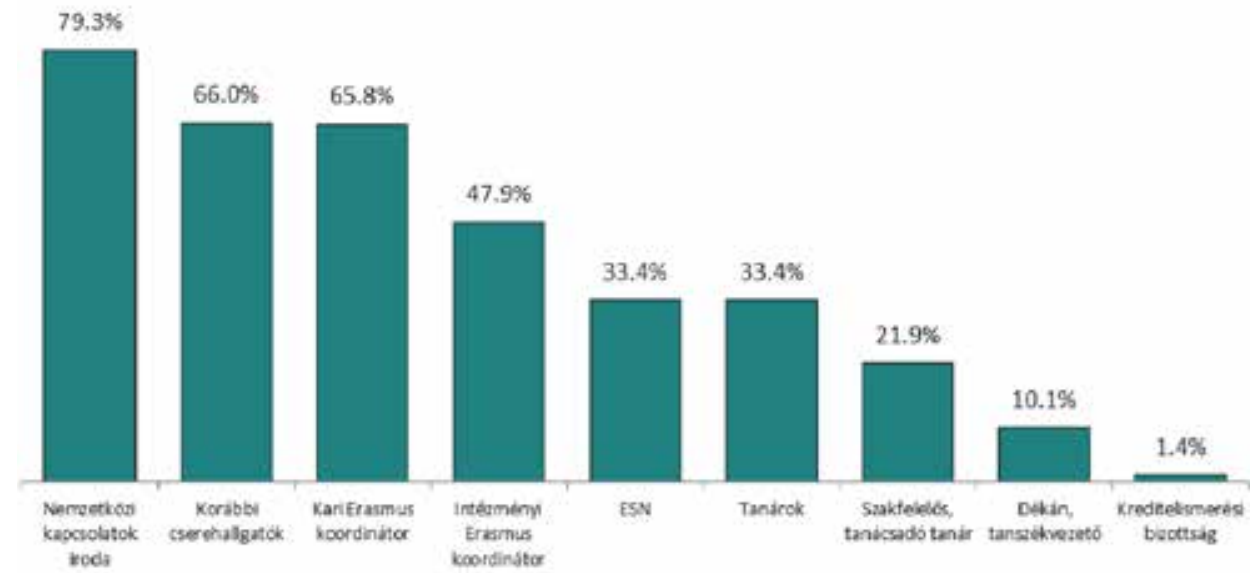

Ha kiemeljük a kreditrendszerre, az értékelési rendszerre vagy az elismerésre vonatkozó forrásokat, a kép árnyaltabbá válik. A 6. ábra alapján tanulságos például az, hogy a hallgatók 26\%-a saját maga tájékozódik a kreditrendszerről. Egy másik érdekesség a felmérésből, hogy az elismerésre vonatkozó arány a legkisebb minden forrás esetén (az ESN szekciók kivételével persze). 
6. ábra: Kiemelt témák információs forrásainak arányai
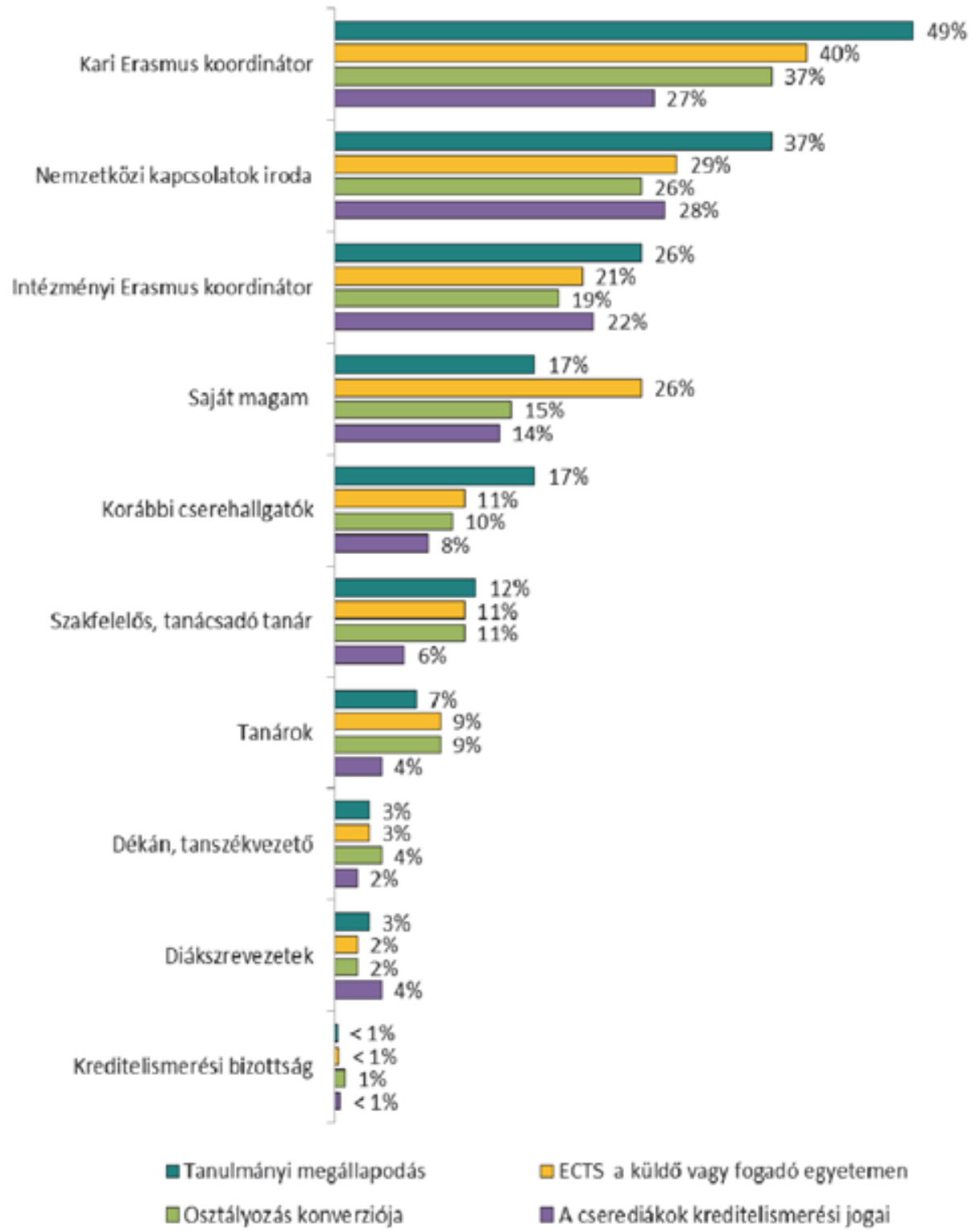

A \%. ábrán azt láthatjuk, hogy a kiutazás előtt a hallgatóknak csak 75,8\%-a tájékozódott (bármilyen forrásból) a kreditrendszerről és kb. 50\%-a az elismerési lehetőségekről. A hallgatók csak 2,3\%-a nem kapott semmilyen forrásból információt az ECTS-ről, az viszont megdöbbentő, hogy állításuk szerint 25,5\% nem kapott az egész folyamat során semmilyen tájékoztatást a kreditek elismeréséről. 
7. ábra: Mikor szereznek a diákok tudomást egyes elemekről

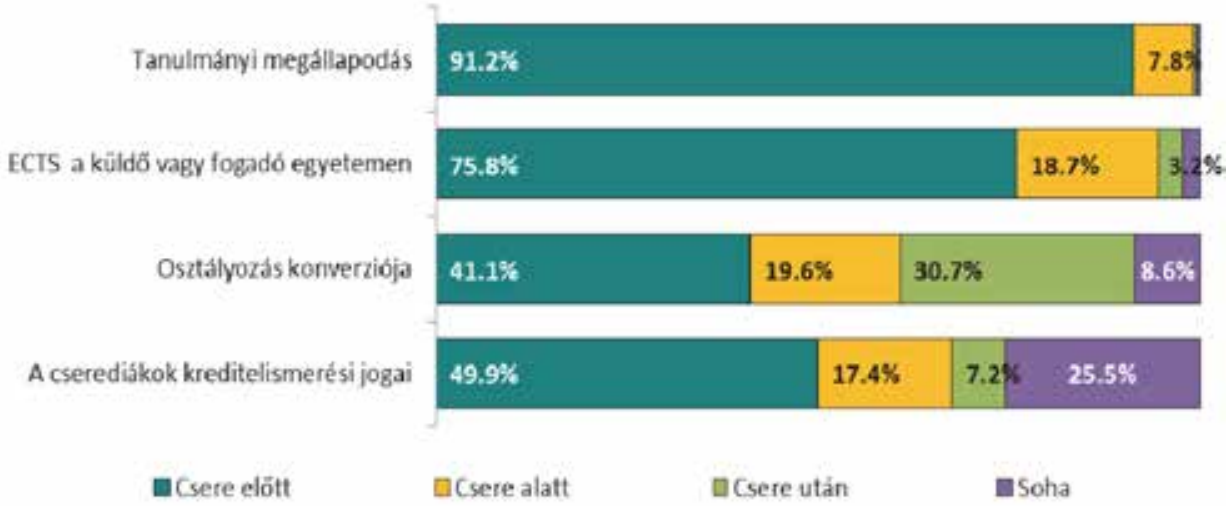

Akikhez végül eljutottak az információk, azok mely forrásokat használták és hogyan értékelték azok hasznosságát? Ezekre a kérdésekre ad választ a 8. ábra. Láthatóan az egyéni konzultációk a leghasznosabbak, de szorosan mögéjük zárkóznak fel a weblapok (ezeket szinte mindenki használja). A papíralapú tájékoztatás láthatóan egyre kevesebb hallgatót ér el, egyre kisebb hatékonysággal.

8. ábra: Információforrások és értékelésük

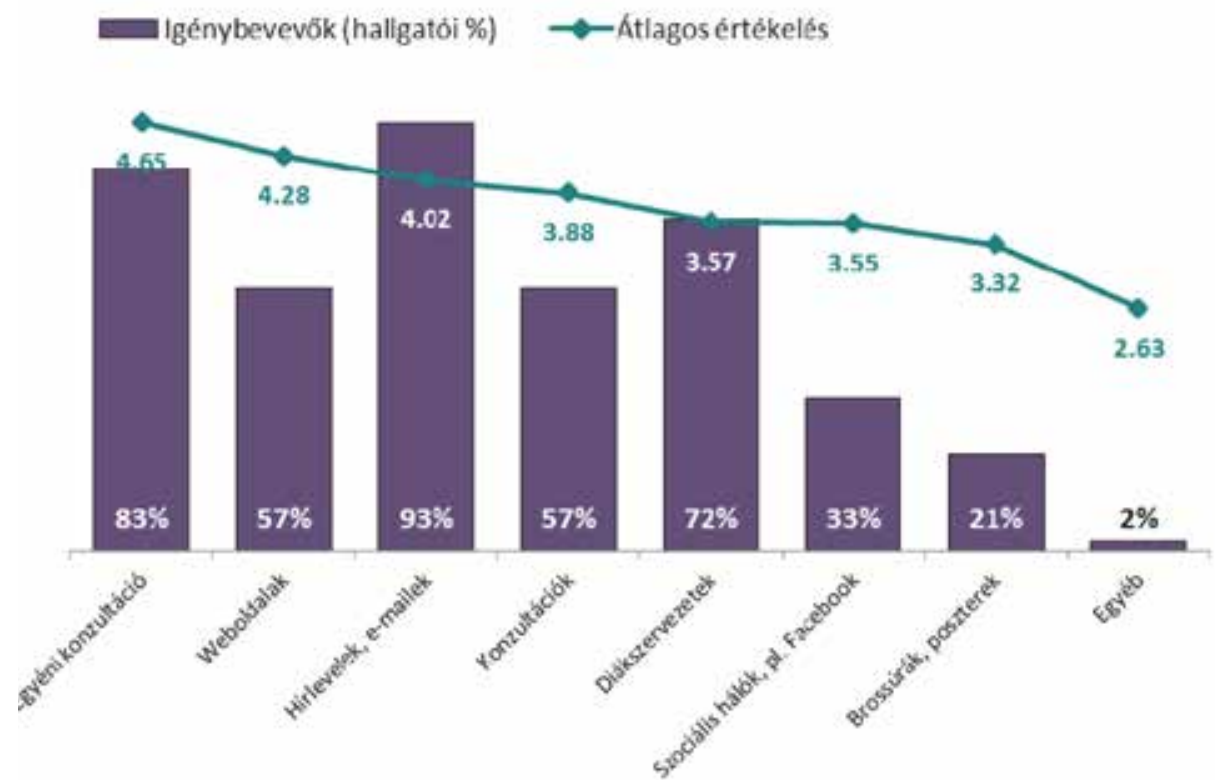

A csere egyik fontos jogi dokumentuma és az elismerés záloga a tanulmányi megállapodás (Learning Agreement). A felmérés szerint a hallgatóknak mintegy 73\%-a írja azt alá előzetesen, 23\% menet közben és vannak, akik utólag írják alá (vagy $2 \%$-ban nem is emlékeznek rá). A tapasztalatok szerint azonban a 
hallgatók 75\%-a a csereidőszak során megváltoztatja a megállapodás tartalmát. Ennek oka 60\%-ban az, hogy az érdeklődése megváltozott, 50\%-ban pedig az, hogy az aláírt kurzus nem indult, 16\%-ban a fogadó intézmény kérte a változtatást, 13\%-ban hosszabbítás miatt történt változtatás (több eset egyszerre is előfordulhatott).

Az intézményi kérdőív alapján is az egyik fő indok az volt, hogy az előzőleg egyeztetett kurzus végül nem indult a fogadó egyetemen.

Az elismerés lényegi technikai eszköze a kreditrendszer. A megkérdezett felsőoktatási intézmények 59\%-ban csak ECTS-t használnak, 37\% együtt használja azt a nemzeti kreditrendszerrel és csak $4 \%$ jelezte azt, hogy egyáltalán nem használja az ECTS-t. A hallgatókat megkérdezve a válasz hasonló: 93\% szerint használták az ő esetében az ECTS rendszert. Az ECTS használatában két tendencia volt kitapintható. Az egyik szerint az ECTS-t a hallgatói terhelés megállapítására használják, itt 25 és 30 óra között van a szokásos elszámolás. A másik tendencia az, hogy a kurzus típusa is számít az átváltásnál (előadás, szeminárium). A válaszokból szemmel látható, hogy a nemzeti rendszerek hiába ECTS-alapúak, eltérések bőven léteznek és az átváltások eltérőek, nincs még igazi harmonizáció.

A kutatás egyik legfontosabb célja az elismerés feltérképezése volt. Kitüntetett szerepe volt a „teljes elismerésnek" (full recognition). Ez a fogalom sem volt azonban egységesen értelmezhető. 72\% tekintette teljes elismerésnek azt, ha a hazaérkező diák minden kurzusát és vizsgáját további követelmények támasztása nélkül elfogadják. $11 \%$ azt is teljes elismerésnek tekintette, ha néhány pótlólagos órára kötelezték hazajövetele után a hallgatót. Ugyancsak $11 \%$ még azt is teljes elismerésnek tekintette, ha a hallgatónak néhány extra számonkérést is előírtak. $6 \%$ egyéb, hasonló definíciókat fogad el teljes elismerésnek.

A kutatásban azt tekintették teljes elismerésnek, ha a hazaérkező diák elfogadott kreditjeinek száma megegyezett a tanulmányi megállapodás kreditjeinek számával, vagy megegyezett a kint megszerzett kreditek számával (függetlenül attól, hogy mi volt a megállapodásban). Ezek szerint a válaszolók 73,1\%-a részesült teljes elismerésben (ezek közül 6\% még több kreditet is kapott). $54 \%$ volt az, aki a megállapodás szerinti teljes elismerést kapta.

Részleges elismerést kapott 24\%, nem ismerték el a kreditjeit 3\%-nak.

\section{9. ábra: A kiváltott kurzusok típusai}

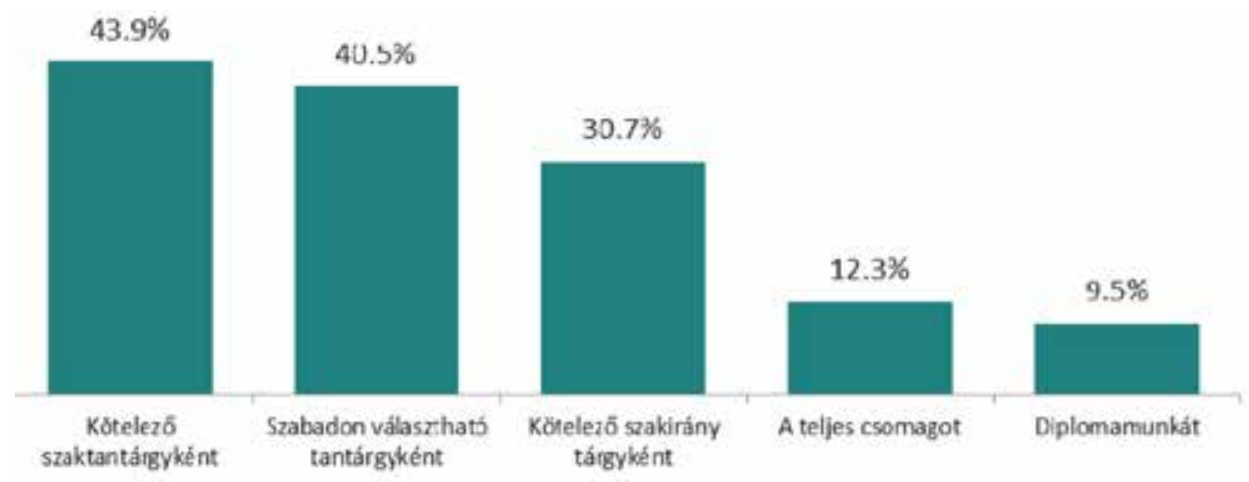

Ha az intézményeket kérték meg, hogy becsüljék meg a teljes elismerést kapott hazatérő diákjaikat, ők a felmérésbeli diákok válaszainál rosszabb arányt mondtak, 60\%-ot.

A kiváltott kurzusok típusát mutatja a 9. ábra. 
Kik játszanak szerepet az elismerési döntésben? Az elemzés szerint itt is az Erasmus koordinátoroknak nagy a szerepe. Érdekesség, hogy a speciális kreditátviteli bizottságokat csak 6,6\%-ban említik.

Amikor a diákokat arról is kérdezték, vajon szükség volt-e arra, hogy (minden vagy néhány kurzus esetében) a professzorokkal egyeztessenek, 51\%-ban volt a válasz igenlő, 38\%-ban minden kinti kurzusra vonatkozóan.

Mint láttuk, mintegy 26\%-a a hazatérő hallgatóknak elismerési problémákkal küzd. A fő okokat a 10. ábra szemlélteti. Látjuk, hogy a legnagyobb arányban a tartalmi problémák dominálnak, majd kreditszámítási és egyéb adminisztratív okok következnek. Az intézményi válaszok megerősítik ezt a sorrendet.

\section{0. ábra:Azelismerésiproblémákokai}

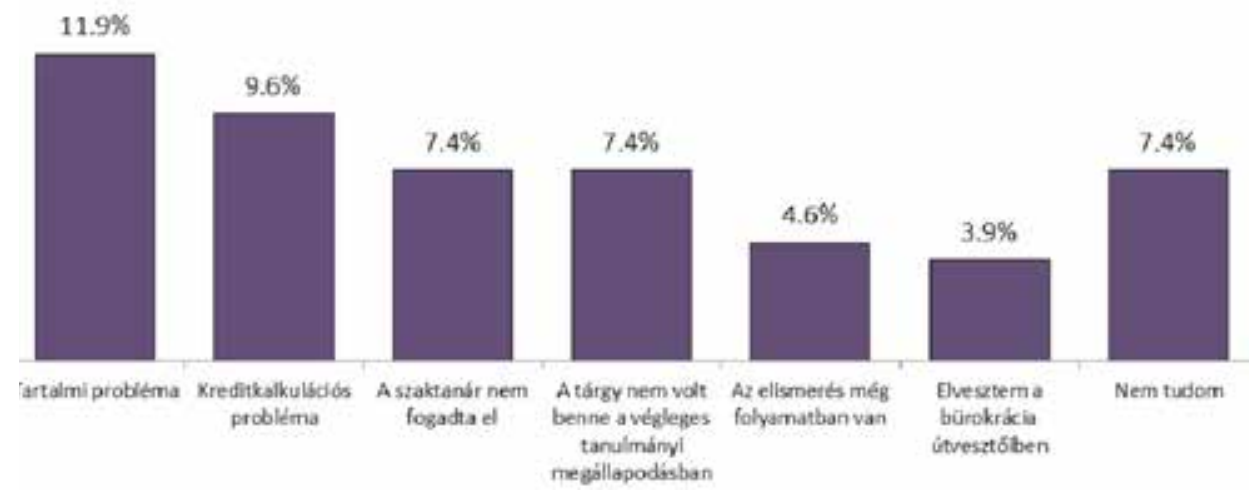

A teljes elismerés fogalmának különbözőségei és a nem elfogadott kurzusok együttesen vezethettek oda, hogy a válaszoló diákok $21 \%$-a ismételt kurzust vagy vizsgát hazatérése után a kint elvégzett tárgyból. Ebbe azonban az is közrejátszott - egy erre vonatkozó kérdés szerint - hogy egyes tárgyakból a professzor a teljes elismerés mellett is bekérte a hallgatót vizsgázni, illetve olyan esetek is voltak, amikor a hallgató jobb jegyért ismételt otthon.

Izgalmas kérdés, hogy az Erasmus hallgatók hány százaléka hosszabbítja meg kényszerűen a tanulmányait a csereidőszak miatt. $77 \%$ ezt nem teszi, $13 \%$ biztosan hosszabbít, míg $10 \%$ még nem tudja, mi lesz a helyzet.

Mit javasolnak a nemzeti ügynökségek?

- Javítani kell a kommunikáción: egyrészt jobban kell informálni a hallgatókat jogaikról és kötelezettségeikről, másrészt az oktatók felkészítése és informálása is fontos, éppen és főleg az elismerések tárgyában.

- Erősíteni kell az intézmények közötti együttműködéseket: érdemes bilaterális kreditegyezményeket kötni.

- Minden szereplőnek tudnia kell a szerepét, felelősségét a folyamatban. Fontos, hogy a kari, tanszéki részvétel is megjelenjen.

- Törekedni kell arra, hogy a tanulmányi megállapodásokat a hallgató kiutazása előtt véglegesítsék.

A jegyek konverziója nem megoldott kérdés. Az intézmények több mint 30\%-a saját konverziós táblákkal dolgozik. Máshol egyáltalán nem is foglakoznak a jegyek átvételével. A káoszt jól mutatja a 11. ábra. 
11. ábra: Az osztályzatok átváltásának módjai

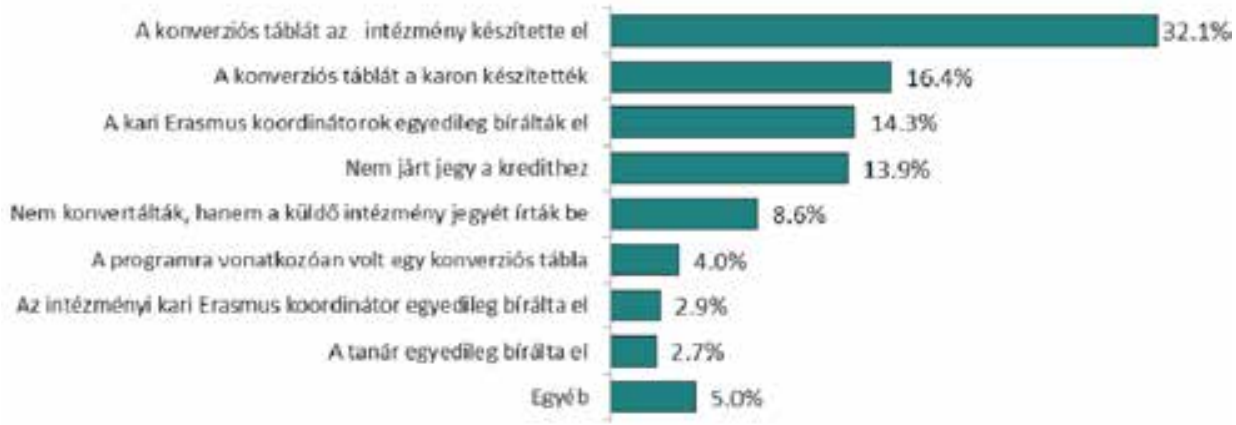

12. ábra: Teljes és részleges elismerés képzési területenként

\begin{tabular}{|c|c|c|}
\hline Orvostudomány & 858 & 158 \\
\hline Müvéscetek & EOS & $20 \%$ \\
\hline Számitástechnika & $79 \%$ & $21 \%$ \\
\hline Pseicholdoga & 773 & $23 \%$ \\
\hline Biológja és biokémia & 775 & $23 \%$ \\
\hline Turizmes & 765 & $24 \%$ \\
\hline Kémia & 768 & $24 \%$ \\
\hline Újșđàirás, kommunikáció, médiatanulmányok & $75 \times$ & $25 \%$ \\
\hline Mènōkè tudományok & $75 \times$ i & $25 \%$ \\
\hline Marketing & $74 E^{2}$ & $26 \%$ \\
\hline Köagazdaságtan & 745 & $26 \%$ \\
\hline Környezettudomány & 733 & $27 \%$ \\
\hline Pénzūgy, bankok, biztositás & 725 & 288 \\
\hline Történelem és archeolögia & $72 \times$ & $28 \%$ \\
\hline Jog és kŏzigargatástan & 718 & $29 \%$ \\
\hline Matematika is statisatika & 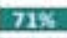 & $29 \%$ \\
\hline Novelés és tanár kêpzés. & $71 \mathrm{R}$ & $29 \%$ \\
\hline Politikatudomány ès nemzetközi kapcsolatok & 715 & $29 \%$ \\
\hline Vezetestudomány & $71 \%$ & 2926 \\
\hline Idegen nyelvek & $70 x$ & $30 x$ \\
\hline Epitesset & $70 x$ & $30 \%$ \\
\hline Kulturalis tanulmámyok & 683 & $32 \%$ \\
\hline Stociológia & 678 & $33 x$ \\
\hline Fizika & 665 & $34 x$ \\
\hline
\end{tabular}

Teljes elismerés aRészleges elismerés

A cserék egyik fontos akadálya a gyökeresen eltérő osztályozási skálák és módszerek használata Európában. A hazaérkező hallgatók 20\%-a érzi úgy, hogy otthon alulértékelték a kinti jegyét és mindössze $42 \%$ elégedett.

A kutatás összefoglalója kritikusan említi, hogy még mindig - a csereprogramok hosszú története ellenére - mintegy 25\%-a a hallgatóknak elismerési problémákkal küzd. Mint említettük, az egyik ok magának a teljes elismerés fogalmának nem egységes értelmezése. A jelentés írói amellett teszik le a voksot, hogy a hazaérkező diáknak sehol és semmilyen tárgyból ne kelljen pótlólagos órákon vagy vizsgákon részt vennie. 
Vannak-e diszciplináris eltérések? Az elemzés kimutatta, hogy vannak (12. ábra).

Kiderült, hogy az is fontos szempont, hogy a kiutazó diák mikor kapja meg a szükséges információkat. Minél később, annál nagyobb a valószínűsége annak, hogy problémái lesznek az elismeréssel.

Egyértelmű, hogy a hazai - hasonló vagy azonos tárgyat oktató - professzor bevonása a folyamatba hátráltató tényező. Ezért lennének fontosak az átfogó bilaterális intézményi egyezmények.

A PRIME elemzők a tanulmányok elismerésének akadályait hat jellemző köré csoportosították. Ezek felsorolása mellett érdemes megjegyezni, hogy mivel ezek a következtetések a diákok és az intézmények által kitöltött kérdőíveken alapulnak, s nagyrészt a volt cserehallgatók véleményét tükrözik, ezért a kialakuló képet árnyalhatja a diákok hozzáállása, teljesítménye is. A felmérés hátterében az is látszik, hogy a diákok egy része nem fordít elég figyelmet külföldi tanulmányaira, nem koncentrál a külföldi tanulmányok sikeres elsajátítására és hamar meghátrál, ha adminisztratív akadályokkal találkozik. Ennek ellenére az eredmények érvényessége - ütköztetve azokat az intézményi véleményekkel és a nemzeti ügynökségek tapasztalataival - az ajánlások megtételére mindenképpen megfelelő.

1. Az egyik legfontosabb probléma a hazai és külföldi tanulmányok elfogadásában a tárgyak inkompatibilitása. Ez nyilván természetesen fakad a különböző felsőoktatási intézmények oktatóinak eltérő szemléletéből is, ám ha ez párosul a hazai (elfogadó) fél rugalmatlan hozzáállásával - amint az gyakran megtörténik - akkor a teljes elfogadás nehezen megvalósítható. A hallgatók egyes esetekben szinte reménytelennek látják egy-egy kötelező tárgy elfogadtatását, ha az nem azonos könyvből, azonos óraszámban, azonos kreditért történt.

A kutatók és a nemzeti ügynökségek a tanulmányi megállapodások komolyabban vételét, az abban foglaltak kötelező érvényesítését látják egy lehetséges kiútnak. Sajnálatos tény az is, hogy maguk a tanulmányi programok is egyre inkább veszítenek rugalmasságukból, egyre kevesebb a szabadon választható tárgy (itt lehetne némely vitatott, „kilógó” tárgyat elismerni a cserediák tanulmányi csomagjában).

Az Erasmus Diákhálózat megfontolásra javasolja egy rugalmas tárgycsomagból felépülo” „mobilitási ablak" (mobility window) beépítését a tanulmányi programokba: ezek tantervi szinten biztosíthatnák az elfogadást.

2. Egy másik lényegi probléma az eltérő kreditkalkuláció. Ez még akkor is létezik, ha a nemzeti rendszer az ECTS-re épül, mivel nincs európai szintű harmonizáció. Az olykor intézményi szinten is folytatott egyedi konverziós gyakorlat zűrzavaros helyzeteket teremthet.

A kreditek tanulmányi órában számolt terhelése változó és gondokat okoz a teljes elfogadásban. A tanterven belüli, a tárgyakhoz rendelt kreditek eltérése is probléma. Mint egy magyar diák írja: „Olaszországban a kurzusok rendszerint 6-9 kreditesek. Magyarországon 2-3 kreditet ér egy kurzus. Hiába tettem vizsgát Olaszországban egy 6 kredites kurzus anyagából, a beszámítás Magyarországon csak 2 kredit. Ha 3 év alatt be akarom fejezni itthoni tanulmányaimat, akkor többlet krediteket kell szereznem extra kurzusok felvételével."

Az ESN javaslata az, hogy az ECTS legyen az elfogadás alapja. Ehhez erőteljesebben kell propagálni és elfogadtatni az ECTS Label kezdeményezéshez való csatlakozást: ez ugyanis minőségi garanciát jelent a kreditek beszámíthatóságára vonatkozóan.

3. A jegyek elfogadása nagymértékben megoldatlan. Az esetek többségében ezt egy-egy oktatóra bízzák, nagyfokú a szubjektivizmus. Mivel a jegyek konverziója európai szinten megoldatlan és az egységesítés irányába tett lépések nem váltak be, az ESN javaslata az, hogy legalább intézményi szinten legyen nagyobb a transzparencia, ismert az eljárás.

4. Egyes országokban, intézményekben a lassú és átláthatatlan bürokrácia gördít akadályokat a teljes elismerés elé. Egész lánc foglalkozik az elismeréssel: bizottság, koordinátor, szakfelelős, tárgyfelelős. Egyes diákok 3-6 hónapokat várnak a döntésre. 
Az ESN fontosnak tartja, hogy az intézményi kreditelismerési rendszer gyors és átlátható legyen. Az információk és a döntések kommunikációja is lényeges.

5. A diákok által említett akadályok közül az egyik leggyakoribb az, hogy az adott tárgyért otthon felelős professzor nem adja meg a teljes elismerést. Olykor a tanulmányi megállapodásban aláírt tárgyakat sem hajlandók elismerni. Az áldatlan helyzeteken egyrészt a tanárok jobb informálása is segíthet (gyakran nem rendelkeznek elegendő információval a cseréről és annak körülményeiről), másrészt pedig érdemes erőteljesebb adminisztratív nyomást is kifejteni annak érdekében, hogy az intézmény által kötött szerződések teljesülését ne akadályozzák.

Nyilvánvaló persze, hogy nagyobb rugalmasságra és bizalomra is szükség van.

6. Az információhiány, illetve a túl későn szerzett információk is gondot okoznak. A küldő és a fogadó intézmény egyaránt sokat tehet a hallgatók jobb és időben történő informálása érdekében.

\subsection{Magyarország: Kreditmonitoring (2005)}

Mit mondanak a magyar tapasztalatok? Az Országos Kredittanács megalakulása óta foglalkozott a kreditelismerés kérdéseivel. Igyekezett a jó és rossz tapasztalatokat egyaránt feltárni és javaslatokat megfogalmazni az intézmények számára. A PRIME felméréssel összevethető (bár nem teljesen azonos célú) felmérést az Oktatási Minisztérium megbízásából, az Országos Kredittanács tagjaiból alakult Szakértői Testület szakmai felügyelete mellett a Magyar Gallup Intézet végezte 2005-ben. 1500 nappali tagozatos hallgató és 665 oktató vett részt a reprezentatív felmérésben 31 felsőoktatási intézményből. A Kreditmonitoring projekt eredményeit folyamatosan közölték (Kreditmonitoring 2005) és visszacsatolták az intézményekhez is.

2005-ben (ne feledjük, ez a Bologna-rendszer hazai bevezetésének éve):

- a tanulmányi előadók érezték magukat a legtájékozottabbaknak, majd az oktatók és legkevésbé a hallgatók,

- a hallgatóknak csak mintegy tizede volt tisztában a kredit által jelzett hallgatói munkaórák számával,

- egyelőre nem terjedt el a kreditrendszer mögött rejlő elvek és gyakorlat ismerete, kevés volt a tudatosság a kreditrendszer előnyeinek kihasználásában.

Mivel (az igen alapos, tudományos igényű) felmérés magának a kreditrendszernek a működésére koncentrált, itt nem részletezzük az eredményeket. Témánk szempontjából az az érdekes, hogy már ekkor megjelent az a kritika, amely szerint az áthallgatás, a kreditelismerés nehézségeket jelent a hallgatók számára. A lehetőségek ismeretének hiánya, az ügyintézés nehézkessége már ekkor is felmerült. Hiányoztak a kreditátviteli bizottságok, a hallgatók egyénileg intézték az elismertetést - elképzelhető bonyodalmakkal. Nem véletlen, hogy az elismerés arányát kevésnek találták.

A fentiek nyilván közrejátszottak - bár számos más ok is volt (nyelvismeret hiánya, költségek, stb., lásd (Kasza 2010) -, hogy a hallgatóknak csak 20-25\%-a gondolkodott egyáltalán külföldi tanulmányokról. A megkérdezettek 4\%-a végzett külföldi tanulmányokat. Közülük $70 \%$ (!) nem kívánta elismertetni a külföldön szerzett krediteket. Azok közül, akik ezt meg kívánták tenni, ez 36\%-nak nem sikerült. Ugyancsak 36\% részben, $21 \%$ teljesen el tudta ismertetni a külföldön szerzett krediteket. Derényi András átfogó tanulmánya a kreditrendszer bevezetésének első évtizedéről nagyban támaszkodik a Kreditmonitoring projektek eredményeire (Derényi 2006). Az európai és a hazai helyzetet összevetve meglehetősen sötét képet fest:

„Európa a hallgatói mobilitás mindenekelőtti prioritását hangsúlyozza és egyre növekvő mértékű forrásokat allokál ennek támogatására. E szemléletmód alapján egyes államok hallgatóik számára kö- 
telező külföldi részképzést is előírnak a diploma feltételéül. A folyamatos pénzügyi és szakmai támogatás eredményeképp elmondható, hogy mára a vándorhallgatók tanulmányai elismerésének lehetősége Európa-szerte adott, körülményei szabályozottak, eszközei bejáratottak. Idehaza eközben szinte „zavaró körülménynek” tekinti a felsőoktatás, ha a hallgatók elhagyják az anyaintézményt külföldi tapasztalatszerzés, tanulmányvégzés céljából. Ez a mentalitás eredményezheti a magyar hallgatók alacsonynak tekinthető mobilitási szintjét és a rendkívül alacsony kreditelismerési arányt. A javuló körülmények ellenére sem kielégítő a magyar gyakorlat sem hazai, sem külföldi relációban. Ez nemcsak az egyéni hallgatói vándorlást, de a külföldi és hazai intézmények közösen folytatott képzéseinek kialakítását, elterjedését - végső soron a hazai felsőoktatás nemzetközi integrációját - nehezíti. A nagymértékű mobilitás egyéb járulékos előnyeitől való megfosztottságról nem is beszélve.”

\section{Magyarország: Tempus felmérések eredményei (2010)}

Az egyik legszélesebb körű kutatás, amely a közelmúltban történt és kitért a kreditelismerés kérdéseire is, 2010-ben készült a Szegedi Tudományegyetem Neveléstudományi Doktori Iskolájában Csapó Benő vezetésével (Tempus 2012). Az adatok 2007-2009 közöttiek, a kreditelismerés intézményi elismerésére kihegyezve, a Tempus Közalapítvány előző vizsgálataiból is merítve. Mintegy 1000 hallgató kérdőíveit dolgozták fel, 20 intézményi mélyinterjút készítettek. Az előző felmérésekkel dolgozva az adatszám jelentősen megnőtt. Javult-e a helyzet a Bologna-rendszerű képzés első öt évében Magyarországon?

Emeljünk ki néhány elemet a kutatási jelentés összefoglalójából:

„A tanulmányi megállapodásoknak csak mintegy kétharmada készül el a külföldi tanulmányok megkezdése előtt, és sok esetben nem tekinthető kielégítőnek az előzetes kurzusekvivalencia dokumentálása sem. A mobilitásban részt vevő kiutazó fiatalok partnerintézményekben teljesített kurzusait az esetek körülbelül felében nem ismerik el teljes körüen a hazai egyetemek és főiskolák, illetve csak 27\% azoknak a tantárgyaknak az aránya, amelyeket a hallgatók a kötelező szaktárgyi kurzusblokkon belül fogadtatnak el. A kreditbeszámítás helyzetére jellemző, hogy a hallgatók 73\%-ának saját bevallása szerint nem volt problémája a külföldön szerzett kreditek elismertetésével, és emellett csak 38\%-uk nyilatkozott úgy, hogy a részképzésben kapott kreditpontok hazai képzésbe történő beszámítása nagyon fontos volt számára.”

„Az intézmények jellemzően abban az esetben tekintenek ekvivalensnek két tantárgyat, és számolnak el krediteket a partnerintézmény kurzusának teljesítésért, ha a tantárgyak sillabuszai, pontosabban azok tartalma, tematikája legalább 75\%-ban megegyezik. Fontos azonban kiemelni, hogy a felsőoktatási törvényben foglalt vonatkozó szabályozás azt írja elő, hogy a tanulási eredmények 75\%-os egyezésekor a két kurzust egyenértékűnek kell tekinteni, de lehetőséget ad arra, hogy ennél kisebb arányú egyezés esetén is megfeleltessenek egymásnak különböző intézményekben teljesített tárgyakat, illetve a törvény alapján a kurzusekvivalenciáról való döntést nem elsősorban a tematikus egyezésnek kellene meghatároznia, hanem a tárgyak teljesítése révén jelentkező tanulási eredményeknek.”

A kutatás a Tempus adatok másodlagos elemzéséből is bemutat néhány jellemző adatot. 2009-ben országos szinten, összesen 3029 hallgató válaszai alapján, a mobilitásban résztvevők 39\%-ának teljes mértékben, 45\%-ának részben számították be külföldön szerzett kreditjeit hazai tanulmányaikba. Azoknak a magyar hallgatóknak az aránya, akiknek a külföldi félévekben teljesített kurzusaiért járó krediteket egyáltalán nem számították be itthon képzésükbe, 2009-ben 16\% volt. 
13. ábra: Kreditbeszámítási arányok Magyarországon

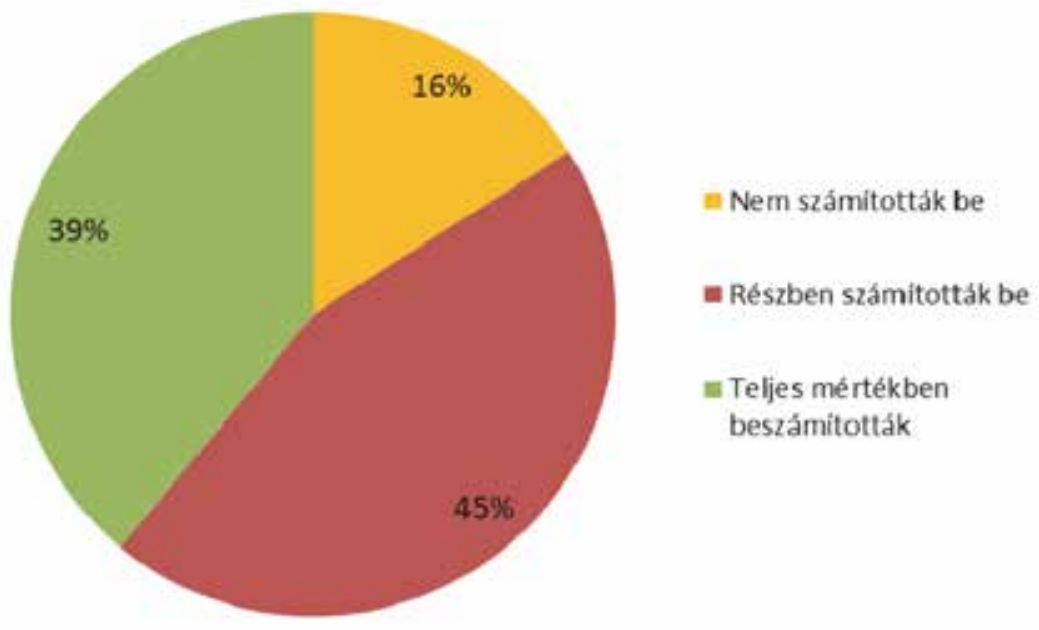

14. ábra: Kreditbeszámítás a vizsgált intézményekben

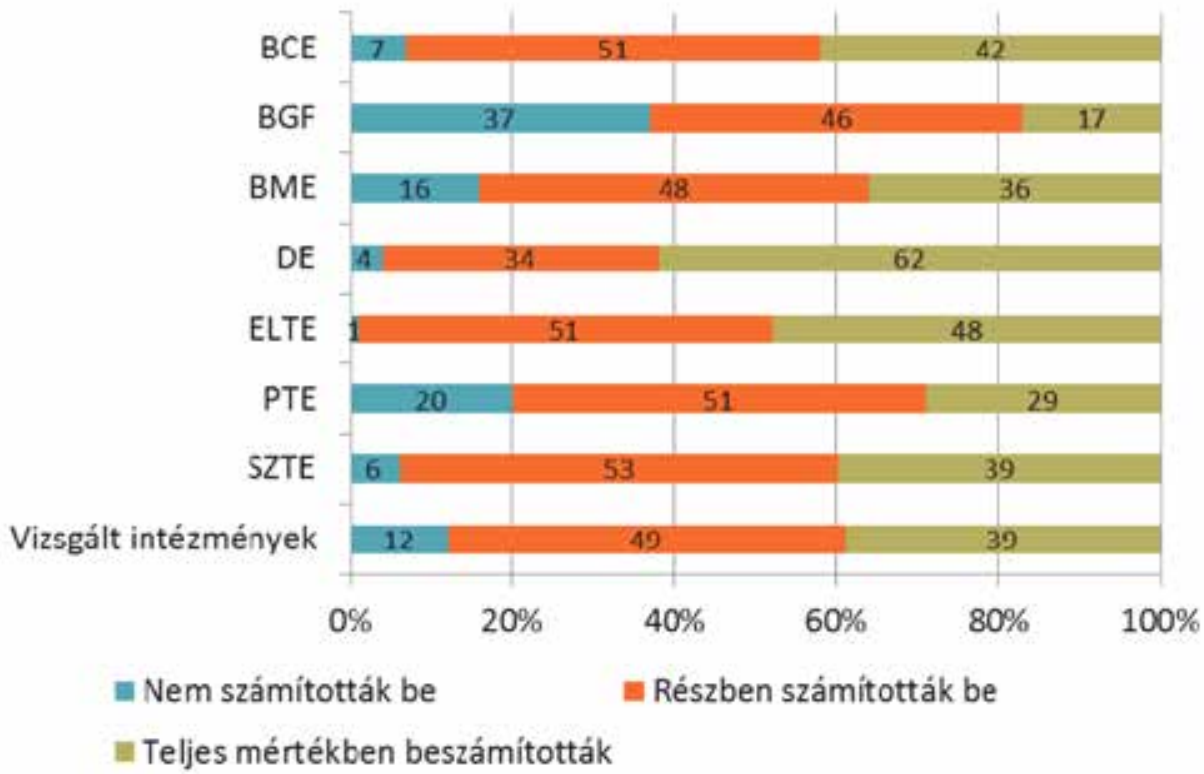

Az intézményi szóródásra is vannak adatok. 2009-ben 7 nagy intézményből összesen 2042 hallgató utazott külföldre, akiknek 88\%-a, összesen 1782 fö szolgáltatott adatot arra vonatkozóan, hogy a mobilitási program során megszerzett kreditjeit az anyaintézmény miként számította be hazai tanulmányaikba (az intézményi mintaelem hasonló: 172 és 332 között változik). A 14. ábráról látjuk, hogy a beszámítási arányok igen különbözőek, a teljes beszámítás két véglete pl. 17 és $62 \%$. 


\section{A kutatási jelentés konklúziói:}

1. A külföldi és hazai tantervek valamint kurzustartalmak eltérése a hallgatók kurzusválasztását, tantárgyak megfeleltetését és a kreditelismerést egyaránt érintik. A probléma kezelését a vizsgált intézményi gyakorlatok egy része a partnerintézmények közötti képzésharmonizációval, más része jellemzően a megfeleltetendő kurzusok tematikus egyezésének rugalmas kezelésével, vagy egy külföldi tanegység több hazai tárgyként való elismerésével kezeli.

2. A hazai és külföldi tanegységek kreditszáma olykor szélsőségesen eltérő az ECTS-rendszer egységes hazai alkalmazásának ellenére is, és gyakran előfordul, hogy a hallgatók a külföldön teljesített kurzusaikért nagyobb számú kreditet kapnak, mint amennyit a megfeleltetett hazai kurzus ér. A teljes körü elismerés megvalósítását elősegíti a fent említett több tantárgynak történő megfeleltetés mellett az az intézményi gyakorlat is, amely megkülönböztetve a kötelező és választható tárgyak kreditelismerésének szabályozását a meg nem feleltethető külföldi kurzusokat a szabadon választható blokkba rendeli, és automatikus tárgybefogadást, valamint kreditbeszámítást tesz lehetővé.

3. A harmadik jellemző problémát az Erasmus-hallgatók nagy kreditértékű tárgyai miatt jelentkező kredittúllépés jelenti. Fontos megemlíteni, hogy az intézmények feltehetően a felsőoktatási törvény kredittúllépésre vonatkozó rendelkezései alapján viszonyulnak az Erasmus-program keretében külföldi tanulmányokat folytató hallgatók esetén is a többletkreditek elbírálásához. A vonatkozó szabályozás szerint a hallgató számára biztosítani kell, hogy képzési programjának teljes kreditszámát 10\%-kal meghaladó kreditértékű kurzust felvegyen és teljesítsen, e kreditszám felett pedig lehetőség van arra, hogy az intézmény a többletkreditekért költségtérítést kérjen tőle. Ennek értelmében van olyan intézmény, ahol az Erasmus-program során szerzett kreditek befogadása nyomán jelentkező többletért is bírságot állapítanak meg. Azonban fontos megemlíteni, hogy a jelenlegi felsőoktatási törvény szerint 58. § (4) „Államilag támogatott képzésben biztosítani kell, hogy a hallgató egyéni tanulmányi rendjében - költségtérítés fizetése nélkül - az összes előírt kreditet tíz százalékkal meghaladó kreditértékű tárgyat vehessen fel." De ez nem jelenti azt, hogy a 10\%-ot meghaladó többletkreditekért az intézmény köteles költségtérítést fizettetni a hallgatóval. Emellett kiemeljük azt is, hogy az Erasmus-program során szerzett kreditek mögött az anyaintézményben oktatói többlettevékenység nem áll, így az emiatt jelentkező többletkreditekért nem feltétlenül jogos költségtérítést fizettetni.

4. Az alanyok említették, hogy az Erasmus-ügyintézésben időnként problémát jelent az, hogy a hazai és külföldi akadémiai év rendje eltér egymástól, illetve nehézségek származhatnak abból, hogy a hallgatói mobilitást megelőző dokumentálás nem minden esetben kielégítő. A vizsgált intézmények gyakorlatai között e problémák megoldására rendszeresített módszer a kurzusok ekvivalenciájának előzetes megállapítása szakmai döntéshozó szerv bevonásával, és ennek rögzítése a Learning Agreementeken vagy egyéb kurzusmegfeleltetési dokumentációban. Az eltérő képzési struktúra, a félévek és trimeszterek különbözőségeiből adódó nehézségek elhárítását a folyamatos intézményközi kommunikáció biztosítja.

5. További, elsősorban a pályáztatásban jelentkező, problémaként/nehézségként észleli az interjúalanyok egy része a bolognai rendszer bevezetését, amely a két képzési szint között hiátust képez a hallgatói jogviszonyban, így a korábbinál kevesebb félév áll a hallgatók rendelkezésére, hogy Erasmus ösztöndíjat szerezzenek. A kapott válaszok alapján a hallgatók teljes körü tájékoztatása és a szemeszterenkénti pályázati rend segítségével ez a hatás mérsékelhető, ezt támasztja alá az is, hogy a kétszintű képzés bevezetését követően is folyamatosan növekszik a mobilitásban részt vevő hallgatók száma hazánkban és a vizsgált intézményekben egyaránt.

6. Az Erasmus kreditelismerési és kurzusmegfeleltetési folyamat központi szabályozása nem ad elég támpontot a gyakorlati megvalósításhoz az intézmények számára. Ugyanakkor a megkérdezettek jellemzően nem szorgalmazzák egységes eljárási rend bevezetését, viszont egy olyan irányadó, köz- 
ponti dokumentum közzétételét szívesen fogadnák, amely a részletes helyi szabályzatok kidolgozásához nyújtana segítséget.

Figyeljük meg, hogy - azon a véletlen egyezésen kívül, hogy itt is hat pont van - az eredmények mennyire egybevágnak a PRIME vizsgálat elemzésével. Természetesen itt azonban már megjelennek a hazai sajátosságok is.

\section{Európa: a várható változások}

Az Európai Unió az új évezredben egyre nagyobb hangsúlyt fektetett az Európán kívüli országokkal történő együttműködésekre, s ezek hangsúlyos eleme volt a hallgatói mobilitás. A legrégebbi kezdeményezések Kanada és az USA irányában indultak el az 1990-es évek elején, erőteljesebb támogatással az ezredforduló után. Az EU-USA együttműködések például a felsőoktatás területén három terminusban folytak, ezek közül volt az utolsó a 2007-2013 között lebonyolított Atlantis program (ATLANTIS 2010). Célja a felsőoktatás (beleértve a felsőfokú szakképzést is) területén innovatív együttműködések támogatása. A fö tevékenységek: „transatlantic degree” programok támogatása; rövidebb hallgatói és oktatói mobilitások szervezése; együttműködési projektek finanszírozása.

Érdekesség, hogy még az igen eltérő kreditfelfogás mellett is kísérlet indult a Tuning módszertan megismertetésére az Egyesült Államokban (EAC 2011). Hasonlóképpen hosszú múltra tekinthet vissza a dél-amerikai program, az ALFA. Mint láttuk, itt a Tuning nagyobb sikert könyvelhet el a CLAR kialakítása révén. A TEMPUS program új, 2000-es évekbeli változata is az Unión kívüli országokkal történő együttműködéseket támogatja. Újabb programok is indultak: Új-Zéland (2004), Japán (2008), DélKorea (2008), ám ezek intenzitása alacsony.

Az Európai Uniós döntéshozók szerint azonban ez az extenzív fejlődés fordulópontjához érkezett. Egyszerűbb, jobban átlátható struktúrára van szükség. Egy példa a jelenlegi bonyolult szervezeti megoldásokra: az élethosszig tartó tanulás (LLL) programja 6 alprogramra bomlott, több mint 50 célkitűzéssel és 60 tevékenységgel. Mára egyértelművé vált: meg kell szüntetni az átfedéseket. A Youth in Action program például 80\%-os átfedésben volt az LLL programmal. Hasonló célokkal, csak földrajzilag változó helyeken szinte azonos programok futottak: az Erasmus Mundus, a Tempus, az Alfa és az edulink, valamint az iparosodott országokkal folytatott együttműködések. Ez a széttöredezettség már a programok hatékonyságát is fenyegette.

A Bizottság úgy döntött, hogy a 2014-2020-as időszakra egyetlen Education, Training, Youth and Sport programot hirdet meg (Erasmus For All 2011). Ez a program Erasmus + néven egyesíti az oktatásra és képzésre, az ifjúságra vonatkozó 2020-ig terjedő programcélokat mind Európán belül, mind pedig a külső partnerekkel. Három kulcstevékenység (Key Action) lesz a továbbiakban: tanulási célú mobilitás, együttműködés és stratégiai reformok. A harmadik féllel történő öt eddigi együttműködési program beolvad a három kulcstevékenységbe. A prioritás mindenütt a mobilitásé.

Mindezen kívül két akció lesz még: a kutatásban elkülönül a Jean Monnet Initiative, és megjelenik egy külön Sport program is.

Az egyéni mobilitásban a hét év alatt nagyjából 5 millió tanulónak kívánnak lehetőséget adni (összehasonlításul: jelenleg mintegy 400 ezer hallgató mobilitását támogatják évente). A felsőoktatási hallgatók célszáma 2165 000, a szakképzési mobilitás tervszáma 765000 fo". 
2020-ig 330000 Erasmus Master hallgató támogatása várható. Külső partnerekkel történő közös programokban 34000 hallgatót fognak támogatni. Az oktatói és adminisztratív személyzet várhatóan 1 millió utazást kap. A nem formális tanulás támogatására is terveznek 540000 helyet.

Az együttműködéseknek négy fő területe lesz: stratégiai partnerség (23000 partnerség / 115000 intézmény; tudásra és készségekre épülő szövetségek (intézmények és vállalatok: 400 / 4000); IT platformok és virtuális mobilitás (3 platform); kapacitásépítés (1000 projekt).

A stratégiai projektek fő irányai: a nyílt koordináció módszere és az európai szemeszter; EU eszközök; stratégiai párbeszéd.

A rendelkezésre álló költségvetés megoszlása a három tevékenységcsoport között: 66,26 és 5\%. A nemzeti ügynökségek működtetésére $3 \%$.jut. Ez a megosztás nem tartalmazza az adminisztrációs költségeket és a Jean Monnet, valamint a Sport akciókat. Ha azokat is bevesszük, akkor az előző felosztás a költségvetés 95\%-ára lesz igaz, a Jean Monnet 2, a Sport 1\%-ot kap a teljes költségvetésből.

A mindenkit érdeklő másik irányú felosztás a szektorok közötti. Itt a legnagyobb növekedést a felsőoktatásnál tervezik. Végleges számok még nincsenek, ezért a becsült összegeket nem érdemes közölni - a lényeg, hogy a teljes (7 éves) költségvetés növekedésével számolnak az előző 7 évvel összevetve.

A kreditelismerés terepe a hallgatói mobilitás. Ha az Európai Unió eddigi felsőoktatási programokkal foglalkozó szervezeti és támogatási felállása gyökeresen megváltozik, akkor az intézményeknek ezekre a változásokra fel kell készülniük. Minden változás kockázatokkal és lehetőségekkel jár. A 2014-2020-as időszakot a magyar felsőoktatási intézményeknek kihasználásra váró fontos esélynek kell tekinteniük. Meg kell azonban érteni, hogy a nemzetköziesedés szerteágazó stratégiai elemei mellett lényeges szerep lesz a technikai felkészülésnek is. Ahogyan a gazdasági versenyben és együttműködésekben azok az országok kerülnek előnybe, ahol stabil infrastruktúra, bankrendszer, jogi környezet várja a befektetőket, a felsőoktatási versenyben és együttműködésben is csak akkor lehet sikerre számítani, ha megfelelő oktatási környezet, nemzetközi sztenderdeken alapuló programok és minőségbiztosítás várja a hallgatókat.

Ennek a tágabb versenykörnyezetnek fontos eleme a kreditelismerés megteremtése. Törvényi szinten már „csak” a képesítési keretrendszer, majd annak implementációja van hátra. A kreditrendszerünk elvileg megfelelő. Intézményi szinten viszont még nagyon sok tennivaló van mind a bejövő hallgatók kiszolgálása érdekében (hatékony adminisztráció, tanulási eredményeket használó tantervek és számonkérési módszerek), mind kimenő hallgatóink tekintetében. Az utóbbi esetben a kreditelismerés hiányosságainak megszüntetése elsőrendű prioritás.

\section{Javaslatok}

Mivel a kreditelismerést - mint többször kifejtettük - a nemzetközi mobilitás elősegítésében kulcselemnek tekintjük, a magyar gyakorlat javítására vonatkozó elveket és módszereket több oldalról fogjuk megközelíteni. A harmadik fejezetben a PRIME szerzőinek javaslatait részletesen ismertettük, ezekre nem térünk ki. Bár sok a hasonlóság a nemzetközi és a hazai problémák között, javaslatainkban elsősorban most már a magyar sajátosságokra kell figyelnünk. 


\subsection{A 2009-es elemzés javaslatai a külföldi résztanulmányok beszámításának eredményesebbé tételére}

A magyar felmérések speciális elemeket is tartalmaztak: a 2009-es vizsgálat (Tempus 2012) például kitért a hallgatói nyilvántartási rendszerek (pl. Neptun) problémáira. „Hazai abszurdként” említette meg a kettős terhelés jelenlétét: sok hallgatónak gyakorlatilag még egy félévet kell a cserefélév melléletennie - ez a tanulmányok meghosszabbodását és időnként fizetési-elszámolási gondokat is okoz. Izgalmas kérdés a hallgatói stratégiák elemzése: mindig érdeke-e a hallgatónak a kreditek elismertetése, beszámítása? (Emlékezzünk rá, hogy 2005-ben még nagyon magas volt azok aránya, akiket ez „nem érdekelt”, 2009-ben már nehezen kimutatható, de még meglévő a jelenség.) A magyar hallgató kevéssé ismeri jogait, a kreditelismerési eljárásban hamar „kedvét veszti”, a tanárral nem harcol, inkább többletterheket vállal.

Szükségesnek látszik, hogy mind a hallgatók, mind pedig az Erasmus-programot gondozó intézményi felelősök munkájának, valamint együttműködésének hatékonyabbá tétele érdekében

1. készüljenek olyan dokumentumok, amelyek az egyes egyetemekre és főiskolákra vonatkozóan egy szabályzatba foglalva, részletesen tárgyalják a kreditelismerés és kurzusbefogadás Erasmusmobilitásra vonatkozó szabályait, valamint valósuljon meg a hallgatók teljes körű, körültekintő tájékoztatása.

A kurzusmegfeleltetés és kreditelismerés előzetes dokumentálásának megújítása, és hatékonyabb alkalmazása érdekében javasolják

2. olyan Learning Agreement használatát a felsőoktatási intézményekben, amelyben a külföldi és hazai tárgyak megnevezése és azok kreditértéke is szerepel.

Az intézményekben a tematikus egyezés helyett a kurzusekvivalencia megállapításakor a

3. tanulási eredményekre alapozott összehasonlítás kerüljön előtérbe, ezáltal növekedhet a kötelező szaktárgyi kurzusokként való tantárgybefogadás az Erasmus-program során.

A hazai intézmények jellemzően a megfeleltetett hazai kurzusok kreditértékén számolnak el krediteket az Erasmus-kurzusokért. Az egyetemek és főiskolák biztosítsanak lehetőséget arra, hogy a külföldön teljesített nagyobb tartalmat lefedő, magasabb kreditet érő tárgyakat az intézmények

4. több hazai tárgynak feleltessenek meg, továbbá

5. új, a képzési programokban eredetileg nem szereplő tárgyakat hozzanak létre a kötelezően és a szabadon választható kurzusblokkok terhére a teljes körű kreditelismerés érdekében.

\subsection{Az Országos Kredittanács javaslatai}

Ugyancsak megszívlelendő de aránylag szűk körhöz jutott el az a dokumentum, amit az Országos Kredittanács 2009-ben készített: Az Országos Kredittanács ajánlása a kreditelismerés folyamatára (OKT 2009). Mivel magam is a dokumentum szerzői között vagyok, különösen szívügyemnek érzem, hogy az anyagban megfogalmazottak eljussanak az intézmények kreditelismerésben résztvevő oktatóihoz, adminisztrátoraihoz, ezért néhány lényegi részt átemelek ide mint jelenleg is abszolút aktuális értelmezést és javaslatot. (A fogalmi magyarázatok fölöslegesen terhelnék ennek a tanulmánynak a terjedelmét, az ajánlás teljes szövege jelenleg is elérhető az OKT honlapján, és egybecsengenek a második fejezetben leírtakkal.)

\section{A kreditelismerés egysége - mit ismerünk el?}

A kreditelismeréskor a hallgató aktuális képzési programjának (tanterv) egy részét teljesítettnek ismerik el a képzési programon kívül elért tanulási eredménye alapján. A magyar felsőoktatásban a képzési 
program jellemzően tantárgyakból áll, ezért a jelen ajánlásban a képzési program elismertetni kívánt részét tantárgyként (elismerni kért tantárgy) értelmezzük. Más tantervi alapegységet használó intézmények a tantárgy helyett ennek megfelelően más egységet használnak, pl. elismerni kért modul, programegység, stb.

Amennyiben nincs a jelenlegi képzési programban olyan tantárgy, amely alkalmas lehet a kreditelismerésben elismerni kért tantárgynak, úgy javasoljuk, hogy helyette egy virtuális tantárgy szerepeljen, amely beilleszthető a megfelelő képzési program követelményének keretébe. Virtuális tantárgy alatt a hallgató képzési programjában egy olyan tantárgyat értünk, amelynek kreditszáma megfelel az elismertetni kívánt kreditértéknek, a tantárgy leírása (különösen a neve) pedig tükrözi azt, hogy ez a tantárgy a kreditelismerés nyomán került bele a hallgató tanulmányi előmenetelébe.

Az elismerni kért tantárgy (mint minden tantárgy) a képzési programban kötöttségét tekintve az alábbi három típusba sorolható.

Ha kötelező tantárgy, akkor az mindig egy konkrét tantervben szereplő tantárgy, amelynek tematikája, követelményei jól meghatározott szakmai ismeretanyagot fednek le.

Kötelezöen választható tantárgy, akkor

- ha létezik a kötelezően választható keretben olyan tantárgy, amely elismerni kért tantárgyként szerepelhet, akkor az elismerni kért tantárgy egy konkrét tantárgy, amelynek tematikája, követelményei meghatározott szakmai ismeretanyagot fednek le;

- ha nincs olyan tantárgy a kötelezően választható keretben, amely elismerni kért tantárgyként szerepelhet, és az intézmény illetékes bizottsága ehhez hozzájárul, akkor az elismerni kért tantárgy egy virtuális tantárgy lesz.

Ha szabadon választható tantárgy, akkor ez a kreditelismerés a szabadon választható követelmény teljesítését szolgálja. Az elismerni kért tantárgy ebben az esetben virtuális tantárgyként kezelhető, melynek nincs adott tematikája és előre meghatározott kreditértéke.

Ha az elismerni kért tantárgy egy virtuális tantárgy, úgy a kreditelismerés ennek a tantárgynak a besorolásából (melyik választható csoportba tartozik) és kreditálásából (hány kreditet ismer el az intézmény) áll. A virtuális tantárgynál ismeretek összevetésére nem kerül sor, csak annyiban, hogy kötelezően választható csoport esetén az elért tanulási eredmény valóban beleillik-e a kötelezően választható csoport által lefedett témakörbe (ha van ilyen). A virtuális tantárgy bevezetése fontos technikai kérdés, de ettől eltérő konzisztens megoldások is alkalmazhatóak.

\section{Ismeretek összevetése}

$\mathrm{Az}$ ismeretek összevetésének tárgyalásakor csak azzal az esettel foglalkozunk, amelyben az elismerni kért tantárgy nem virtuális tantárgy, és részletesen leírt követelményekkel rendelkezik. Az elismerés folyamata abból áll, hogy a kreditátviteli bizottság az elért tanulási eredményt összeveti az elismerni kért tantárgy ismeretanyagával. Ha az ismeretek (elért tanulási eredmények) egyezése legalább hetvenöt százalékos, a korábbi tanulmányi teljesítményt el kell ismerni, de a bizottságnak lehetősége van kisebb mértékü egyezés esetén is elfogadni az elért tanulási eredményt.

Az ismeretek (elért tanulási eredmények) megfeleltetése egy sajátos érvényesítési (validálási) folyamat keretében történik, legtöbbször egy összetett, nem teljesen szabatos összehasonlítással. A különböző képzési programok miatt valószínű, hogy az elért tanulási eredményhez és az elismerni kért tantárgyhoz más-más kreditérték, tantárgyi program, illetve ezekhez eltérő tanulmányi segédanyag tartozik. A tantárgyak leírásában több olyan információ található, amely árnyaltabb és pontosabb képet ad a tantárgy által lefedett ismeretekről (elért tanulási eredményekről).

A legkézenfekvőbb módszer az, ha a tantárgyprogramot, illetve a megszerzendő ismeretek, elsajátí- 
tandó alkalmazási (rész)készségek és (rész)kompetenciák (együtt: elért tanulási eredmények) leírását vesszük alapul, nevezetesen a tantárgyi tematika összehasonlítását végezzük el, de ez nem feltétlenül ad megfelelő információt az ismeretek meghatározásához.

- Felmerül a kérdés, hogy egy ugyanolyan tantárgyi programot tartalmazó tantárgy ugyanazt az ismeretet fedi-e le, ha az egyik tantárgy 3 kredit értékü hallgatói munkaórával számol, a másik pedig 5 kredittel?

- Vajon egy idegen nyelv tanulásakor befolyásolja-e az ismeretek megszerzését pl. a létszám vagy a tanulási módszer? Adhat-e pl. egy 2 kredites spanyol nyelv tantárgy ugyanolyan ismeretet, ha csak hárman vannak egy csoportban, mint egy 4 kredites spanyol nyelv tantárgy, amelynek a csoportlétszáma húsz fö?

- Egyes tanulási eredményeknek elévülési ideje is lehet. Vannak tudományok, amelyek fejlődése anynyira gyors, hogy a megszerzett tudás pár év alatt elévül (pl. informatika).

- Az ismeretek alkalmazásának gyakorlása is az ismerethez tartozik. A fenti kérdések rávilágítanak arra, hogy az ismeretek (elért tanulási eredmények) minőségéhez, belső összetételéhez az elért tananyagon túl más is hozzájárulhat, pl. az oktatási módszer, a számonkérési rendszer, a gyakorlat/elmélet aránya, az elsajátított tudás alkalmazása, a tanulmányi segédanyag (tankönyv, jegyzet), illetve a ráfordított munkaidő. Mindezekről a tantárgyleírás más jellemzői nyújtanak bővebb információt: a kredit, a kontaktóra, a tantárgyi szakmai tartalom elsajátításának célja, a rövid tantárgyprogram, a megszerzendő ismeretek, elsajátítandó alkalmazási (rész)készségek és (rész)kompetenciák (együtt: elért tanulási eredmények) leírása, a tanulásszervezés módjai, az évközi tanulmányi követelmények, az értékelés módszere, az ismeretek, készségek és kompetenciák elsajátításához rendelkezésre álló tanulmányi segédanyagok, az ajánlott irodalom, stb.

Ezzel a megközelítéssel a törvényben meghatározott, ismeretekre vonatkozó hetvenöt százalékos egyezés eldöntése a tantárgyleírás alapján kifinomultabb lehet, és lehetőséget ad arra, hogy a kredit vagy a tantárgy programjának azonosságán vagy eltérésén túl más szempontok is megjelenjenek és befolyásolják a lefedett ismeretek (elért tanulási eredmények) azonosítását és értékelését.

\section{Az elismert tantárgy beszámítása: tanulmányi előmenetel és tanulmányi teljesítmény}

Az elismert tantárgy a hallgató tanulmányi előmenetelébe mindig beszámít. Az elismert tantárgyat a megfelelő kreditértékkel teljesítettként kell elismerni az intézményi tanterv teljesítésének ellenőrzésekor. A kreditelismeréssel beszámított tantárgyaknál a kreditelismerés tényét nyilván kell tartani.

Az elismert tantárgynak a hallgató tanulmányi teljesítményébe (kreditindex, korrigált kreditindex) történő beszámítására a következő szabályok érvényesítését ajánljuk:

1. Az aktuális képzési időszakot megelőzően elért tanulási eredmény alapján elismert tantárgy nem számítható be a hallgató tanulmányi teljesítményébe.

2.Az aktuális képzési időszakban (pl. félév) elért tanulási eredmény alapján az elismert tantárgy csak akkor számítható be a hallgató tanulmányi teljesítményébe, ha ezt a szándékot a képzési időszak elején (regisztrációs időszak végét megelőzően) az intézmény és a hallgató előre rögzítette (pl. Erasmus „Learning Agreement”-ben). A képzési időszak elején a regisztrációs (tantárgyfelvételi) időszakot értjük. A tanulmányi teljesítményhez az elért tanulási eredmény magyar rendszerbe konvertált érdemjegyét kell figyelembe venni. Ebben az esetben a hallgató képzési időszaka az elismerést folytató intézményben aktívnak számít, akkor is, ha ebben az intézményben nem vett fel tantárgyakat.

Nagyon tanulságos az OKT által kidolgozott példák áttekintése. Ezeket a függelékben közöljük, csakúgy, mint a kidolgozott kreditelismerési lapot, amelynek elterjedése egységesítő hatással lehetne a magyar felsőoktatási intézményekre. 


\section{3. Összefoglaló javaslatok}

\section{Az országos szintü szabályozás egyes elemeinek fejlesztése}

1. Magyarországnak 2013-as határidővel nemzetközi kötelezettsége volt az országos képesítési keretrendszer implementálása és illesztése az európai keretrendszerhez. Egy rendelet a teendőket meghatározta ugyan, de azóta kevés előrehaladás történt. Kívánatos lenne, hogy a magyar keretrendszer törvénybe iktatásával párhuzamosan a kreditrendszer fejlesztése is megtörténjen. Vagy a keretrendszert életbe léptető törvényszövegben, vagy önálló rendeletként fogalmazhatók meg az új elemek, pl.:

- a kreditek összekapcsolása a tanulási eredményekkel,

- a kreditek beépítése a keretrendszerbe,

- az adminisztráció és dokumentáció új formái.

2. Az előző ponttal összefüggésben megvalósuló új szervezeti felállásban (a keretrendszerhez kapcsolódó tanácsadás, fejlesztés, hatósági feladatok) szükség van egy olyan szakmai stáb felállítására is, amelyik a kreditrendszerrel kapcsolatos kérdésekben foglal állást, nyújt az intézményeknek segítséget. Nem a Kredittanács újraélesztéséről lenne szó, hanem egy olyan szakértői csapatról, akik már nem a kredit megismertetésével és bevezetésével foglalkoznak, hanem elsősorban az alkalmazás, s ezen belül is a nemzetközi kreditelismerés problémáira keresik a válaszokat.

3. Érdemes lehet a hazai és nemzetközi kreditelismerés formai és tartalmi szabályozására is kísérletet tenni. A jelenlegi gyakorlatban az intézmények sokféleképpen, egyes esetekben akár egészen eltérő módon értelmezik a törvényi és rendeleti passzusokat, az ajánlásokat vagy nem ismerik vagy nem fogadják el. Az egységesítés irányában történő elmozdulás érdekében szükség lenne egy rugalmas, de alapelveiben kényszerítő elemeket és útvonalat tartalmazó útmutatóra. A Kredittanács kredielismerési adatlapja egy lehetséges megvalósítást tükröz, ám aktualizálandó.

\section{Kreditegyezmény-rendszer kidolgozása}

4. A magyar kreditrendszer kialakításának hőskorában sok szó esett arról, hogy a magyar hallgatók hazai áramlását, áthallgatását, annak bővítését a kreditrendszernek is segítenie kell. Különösen fontos a különböző hazai intézmények azonos akkreditált szakjain tanultak elfogadása. Viszont mint tanulmányunkban is láttuk, mivel a kreditelismerést sok helyen a szaktanárokra bízták, az eljárás általában nehézkessé vált, egyesek a minőség védelmének örve alatt saját tárgyaikat „védték”. Érdemes tehát egy olyan intézményi láncot kialakítani, ahol az azonos vagy hasonló akkreditált programok szakfelelősei a tantervek, tantárgyak, tartalmak, tanulási eredmények, számonkérési módszerek alapos vizsgálatával tárgyakra, tárgycsoportokra mondanak ki ekvivalenciát, s amely lánc egy-egy bilaterális egyezményből újabb tagok bevételével egyre bővülhet. A szakokra épülő kreditegyezmények megléte esetén egy informatika szakos hallgató tehát biztonsággal tud például Győrből Debrecenbe látogatni akár egy félévre is - nem lesz kreditelismerési problémája, ha létezik a két intézmény informatikai szakjaira vonatkozóan az egyezmény. Az egyezményrendszer önkéntességen alapulhat, ám a felsőoktatás irányítói gondoskodhatnak megfelelő ösztönzőkről (pályázat).

5. Ugyanez a gondolat a nemzetközi cserékben is megvalósítható. Mivel a nemzetközi hallgatói mozgások zöme szervezett formában zajlik s az intézmények általában országonként kiemelt partnerekkel dolgoznak, ezért egy-egy kar ezekkel a kiemelt partnerekkel (a legnagyobb csereforgalmat lebonyolító szakokra vonatkozóan) elvégezhet egy olyan tantervi elemzést, ami egy kreditegyezmény alapjául szolgálhat. Ez a vizsgálat 3-5 évenként frissíthető (de folyamatos karbantartás is lehetséges). Ha az intézmények tanárai 
vállalják az előkészítő munka terhét, az a továbbiakban a kvázi-automatikus kreditelismerés révén megtérül. A hallgatók ekkor a tanulmányi megállapodást könnyen tudják megkötni és biztonságos hazatérést garantál számukra az egyezmény.

\section{A felsőoktatási intézmények nemzetközi kreditelfogadási gyakorlatában az egységesítés irá- nyában történő elmozdulás módozatai}

6. Az intézmények kreditelismerési szabályzatait frissíteni érdemes. A frissítésnek tartalmaznia kell:

- a kreditelismerés súlypontjának áttolódását a formális 75\%-os tartalmi megfeleltetésről a tanulási eredmények megfeleltetésére,

- az intézmény kreditelismerési folyamatának leírását, annak szereplőivel, feladataival, jogosítványaival és a folyamat egyes elemeinek határidőzésével,

- a kreditelismeréshez szükséges dokumentumokat.

A frissítéshez használják fel a Kredittanács ajánlásait.

7. Az intézmény alakítsa ki az osztályzatok átvételére vonatkozó elveit és azt világosan közölje a kiutazó hallgatókkal.

8. A nemzetközi mobilitásért felelős intézményi szervezetek, koordinátorok, tanárok munkájában nagyobbhangsúlyt kell adni abe-és kiutazó hallgatók előzetes (utazás, illetvefogadás előtti) informálásának.

9. A kreditelismerési folyamat átláthatóságát biztosítani kell.

10. Az intézmény tekintse át szerződéses portfolióját és a kiemelt partnerekkel kezdjen kreditegyezmények megkötését célzó tárgyalásokat.

\section{Felhasznált irodalom}

ACCESS 2010 Strategies to strengthen collaboration in Higher Education between Europe and South East Asia, September 2010, EC-Erasmus Mundus ACCESS project, White paper http://www.seaairweb.info/Collaborations/2010ACCESSWhitePaper.pdf

ACTS 2011 A Base Paper on Asian Credit Transfer Systems (ACTS) 13 September 2011, Le Meridien, Kuala Lumpur, Malaysia http://acts.aeu.edu.my/sites/default/files/BasePaperOnACTS.pdf

ASEMUNDUS 2009 Succeeding in European-Asian Higher Education Cooperation, ASEMUNDUSGood Practice Report, Erasmus Mundus Project, 2009-2013, http://www.asem-education-secretariat.org/en/12184/

ATLANTIS 2010 EU-US Cooperation programme in higher education and vocational training ATLANTIS: Actions for Transatlantic Links and Academic Networks in Training and Integrated Studies Programme Guide

http://eacea.ec.europa.eu/bilateral_cooperation/eu_us/funding/docs/2010/guidelines_en.pdf Bologna 2012 The European Higher Education Area in 2012: Bologna ProcessImplementation Report CLAR 2013 CLAR Latin American Reference Credit, Tuning Latin America Project, 2013, University of Deusto, Bilbao, 
http://www.tuningal.org/en/publicaciones/cat_view/47-publicaciones-libros

CoRe 2010 A Tuning Guide to Formulating Degree Programme Profiles Including Programme

Competences and Programme Learning Outcomes, Competences in Education and Recognition Project (CoRe), (Jenneke Lokhoff and Bas Wegewijs (Nuffic), Katja Durkin (UK NARIC), Robert Wagenaar, Julia González, Ann Katherine Isaacs, Luigi F. Dona dalle Rose and Mary Gobbi (TUNING) (eds.) Bilbao, Groningen and The Hague, 2010, http://www.core-project.eu/

Credit Framework 2008 Higher education credit framework for England: guidance on academic credit arrangements in higher education in England, August 2008, The Quality Assurance Agency for Higher Education 2008 http://www.qaa.ac.uk/Publications/InformationAndGuidance/Pages/Higher-education-creditframework-for-England-guidance-on-academic-credit-arrangements-in-higher-education-inEngland-Augu.aspx

Development and Management of Joint Programmes with Non-European Partners, JOIMAN Network, 2011, https://www.joiman.eu/ProjectResults/default.aspx

Derényi 2006 A tanulmányok elismerésének hazai környezete és gyakorlata. A máshol szerzett kreditek kezelésének problémái (Derényi András)

http://www.scholarship.hu/LinkClick.aspx?fileticket=Yzpo-OAjcg\%3D\&tabid=144\&language=hu-HU

EAC 2010 Co-operation in Higher Education between the United States of America and the European Union to produce a robust methodology to evaluate the application of the Tuning approach Negotiated procedure EAC/59/2010, European Commission DG Education and Culture, Contract number EAC-2010-1243, Final report

http://ec.europa.eu/education/eu-usa/doc/tuningreport_en.pdf

EAR 2012 European Area of Recognition Manual, Practical guidelines for fair recognition of qualifications, Nuffic, 2012 http://www.eurorecognition.eu/

ECTS Guide 2009 European Commission (2009): ECTS User Guide: http://ec.europa.eu/education/ lifelong-learning-policy/ects_en.htm

Erasmus For All 2011 Communication from the Commission to the European Parliament, the Council, the European Economic and Social Committee and the Committee of the Regions ERASMUS FOR ALL: The EU Programme for Education, Training, Youth and Sport, Brussels, 23.11.2011 COM(2011) 787 final, http://ec.europa.eu/education/erasmus-for-all/doc/com_en.pdf

JOIMAN 2011 Good Practice Report for the Management and Administration of Joint Programmes, JOIMAN Network, 2011

Kasza 2010 Helyzetkép a nemzetközi hallgatói mobilitásról - Jellegzetességek és problémák a Diplomás kutatás 2010 eredményeihez kapcsolódva (Kasza Georgina)

http://www.felvi.hu/pub_bin/dload/DPR/dprfuzet4/Pages177_192_Kasza.pdf

http://www.kreditiroda.hu/

Kreditlap 2013 A kreditrendszer kialakulása Magyarországon. http://www.kreditlap.hu/kredit/mo.asp

Kreditmonitoring 2005 „Országos Kreditmonitoring Projekt”, 2005.

A vizsgálatok részletei, eredményei elérhetők:

http://www.kreditlap.hu/kredit/jelenleg/default.asp

OKKR 2011 Az Országos képesitési keretrendszer kialakitása Magyarországon: nemzetközi háttér, elvi megfontolások, megvalósítási javaslatok (szerk. Temesi József), Oktatáskutató és Fejlesztő Intézet, Budapest, 2011 http://tamop413.ofi.hu/okkr-orszagos-kepesitesi-keretrendszer 
OKT 2009 Az Országos Kredittanács (OKT) ajánlása a kreditelismerés folyamatára, 2009 http://www.kreditiroda.hu/doc/ajanlas_kreditelismeres_3.7.pdf

PRIME 2010 Problems of Recognition in Making Erasmus, ESN Report (Eren Dicle, Julia Fellinger, Luyedan Huang, Igor Kalinic, Justyna Pisera, Julia Trawińska, Edona Vinca), ESN, 2010 http://prime.esn.org/final-report

Tuning 2005 Tuning Educational Structure in Europe- Final reports Phase 1 and 2 (2005), http://tuning.unideusto.org/

Temesi 2007 A felsőoktatási kreditrendszer, a képesitési keretrendszer és az ekvivalencia összefüggései (Temesi József), Educatio, 16. évf., 2. sz., 2007. nyár, 217-230 pp.

Tempus 2012 Az Erasmus program keretében külföldön szerzett kreditek beszámitása itthon: helyzetképelemzés és jó gyakorlatok feltérképezése, Szegedi Tudományegyetem Neveléstudományi Doktori Iskola, Bologna füzetek 9, Tempus Közalapítvány, 2012, Csapó Benő, Nagy Zsuzsanna, Pásztor Attila, Hódi Ágnes, Tóth Edit, Hülber László http://www.tpf.hu/pages/books/index.php?books_id=261

Trends V 2007 Trends V: Universities shaping the European Higher Education Area. An EUA report (David Crosier. Lewis Purser, Hanne Smidt)

UNESCO 2009 Trends in Global Higher Education: Tracking an Academic Revolution, A Report Prepared for the UNESCO 2009 World Conference on Higher Education (Philip G. Altbach, Liz Reisberg, Laura E. Rumbley) http://unesdoc.unesco.org/images/0018/001831/183168e.pdf 


\section{Mellékletek}

\subsection{Kreditelimerési lap}

\begin{tabular}{|l|l|}
\hline \multicolumn{2}{|l|}{ A hallgató azonosító adatai } \\
\hline Név: & \\
\hline Tanulmányi rendszer azonosító: & \\
\hline $\begin{array}{l}\text { Intézmény/Kar } \\
\text { (ahol a kreditelismerést kéri): }\end{array}$ & \\
\hline $\begin{array}{l}\text { Szak, szakirány } \\
\text { (ahol a kreditelismerést kéri): }\end{array}$ & \\
\hline \begin{tabular}{l} 
Értesítési cím, telefonszám: \\
\hline
\end{tabular}
\end{tabular}

Korábbi tanulmányi teljesítmény / Elért tanulási eredmény

Megszerzésének módja:

\tanulmány $\square$ munkatapasztalat

¿ egyéb:

Megszerzésének helye (intézmény/képzés, munkahely):

Megszerzésének ideje:

Elért tanulási eredmény leírása (korábban teljesített tantár-

gy(ak) neve, kreditértékkel, eredménnyel,

vagy munkahelyi beosztás, feladat, egyéb eredmény):

Jelenlegi képzésében az eddig elismert kreditek száma:

korábbi tanulmányokból:

korábbi munkatapasztalatból:

korábbi egyéb forrásból:

Kérjük, csatolja az elért tanulási eredményét igazoló és leiró dokumentumokat!

Tanulmányi eredményhez a leckekönyvi másolatot és részletes tárgyleírást, munkahelyi tapasztalathoz a munkaköri leírást, értékelést kérjük mellékelni. 


\begin{tabular}{|l|l|}
\hline Elismerni kért tantárgy \\
\hline $\begin{array}{l}\text { Q Jelenlegi képzés konkrét tantárgya } \\
\text { Tantárgy kódja, neve: }\end{array}$ \\
\hline Tantárgy kreditértéke: & \\
\hline Tantárgyfelelős: & \\
\hline \begin{tabular}{l} 
Q Nincs konkrét tantárgy a tantervben (virtuális tantárgy) \\
\hline
\end{tabular} & \\
\hline Választható keret neve, azonosítója: & \\
\hline Kreditérték: & (kreditátviteli bizottság határozza meg) \\
\hline $\begin{array}{l}\text { Az elismerni kért tantárgy konkrét tantárgy, vagy egy kötelezően választható, illetve szabadon választ- } \\
\text { ható keretbe tartozó virtuális tantárgy lehet. }\end{array}$ \\
\hline
\end{tabular}

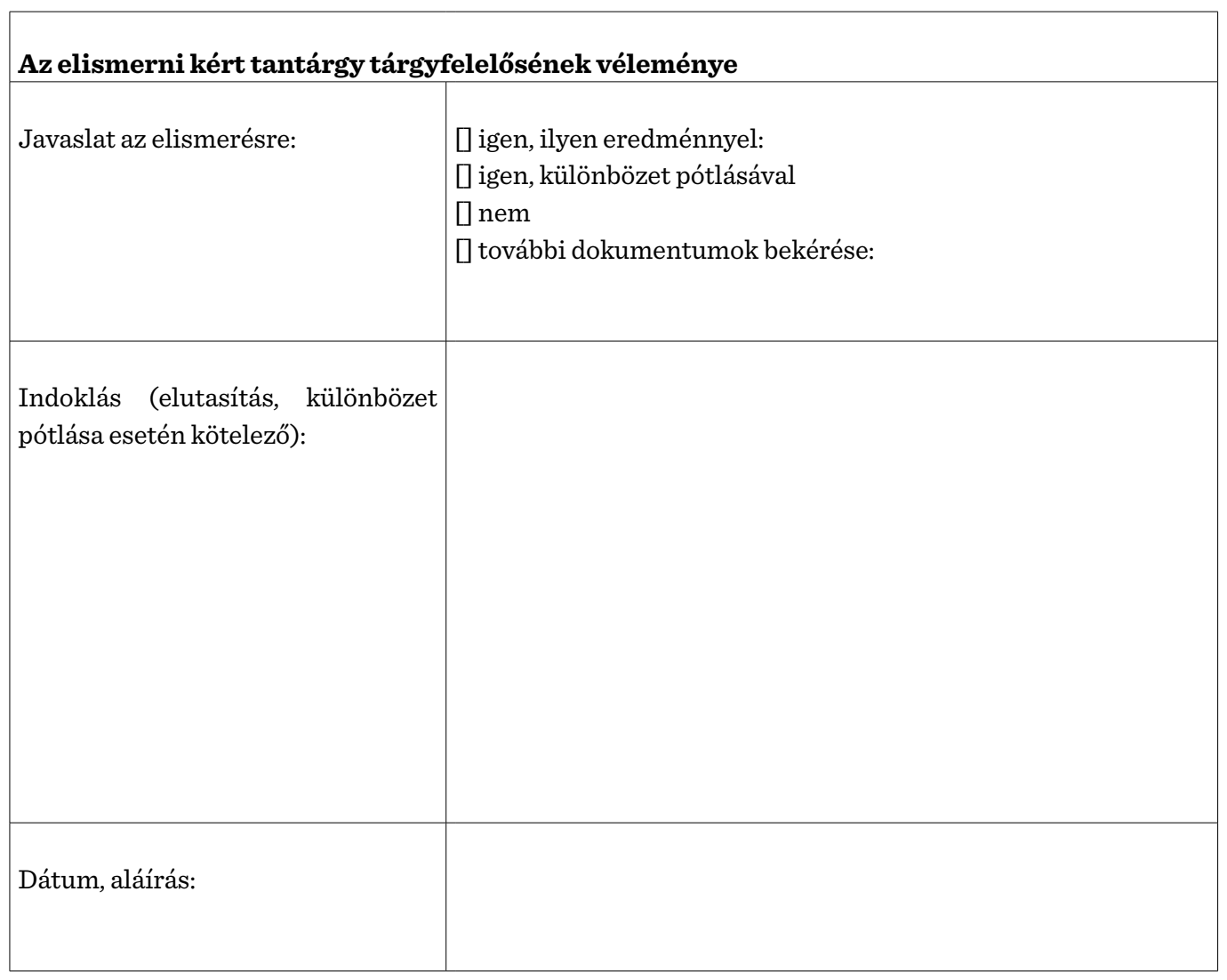




\begin{tabular}{|c|c|}
\hline \multicolumn{2}{|l|}{ A kreditátviteli bizottság döntése } \\
\hline Döntés: & $\begin{array}{l}\square \text { elfogadva } \\
\square \text { sikeres különbözeti pótlással elfogadva } \\
\text { \elutasítva }\end{array}$ \\
\hline Eredmény: & \\
\hline Tanulmányi teljesítménybe: & \ beszámít $\square$ nem számít be \\
\hline $\begin{array}{l}\text { Indoklás (elutasítás, különbözet pót- } \\
\text { lása esetén kötelező): }\end{array}$ & \\
\hline Dátum, aláírás (elnök): & \\
\hline
\end{tabular}

Az Országos Kredittanács

ajánlása a kreditelismerés folyamatára

\subsection{Példák kreditelismerésre}

1. Egy agrármérnöki mesterszakos hallgató egy másik intézményben „Biokémia” tantárgyat (2 kredit) teljesített, amelynek ismerete szinte teljesen azonos az aktuális képzési program elismerni kért tantárgyával („Biokémia”, 3 kredit), kivéve, hogy a saját intézményében az elismerni kért tantárgynak előfeltétele a „Bevezetés a biológiába” kötelező tantárgy, amelyet még nem teljesített a hallgató. A tantárgyfelelős megállapítja, hogy a hallgató által elsajátított tanulási eredmény megfelel az elismerni kért tantárgy követelményeivel. A kreditátviteli bizottság elismeri a tantárgyat (a tantárgy előfeltételének jelölt tantárgyat később kell a hallgatónak teljesíteni).

2. Egy szabad bölcsész alapszakos hallgató szeretné elismertetni a „Modern idegennyelvi szakszövegolvasás” tantárgyat (3 kredit), amelynek keretében különböző angol nyelvű filozófiai szakcikkeket olvasnak a hallgatók. A hallgató korábban egy másik intézményben teljesített egy „Kortárs filozófusok müvei angolul” tantárgyat, ahol bizonyos filozófusok (Ch. Nelson, J. Speaks) angol nyelvű szakcikkeit 
olvasták. Ch. Nelson és J. Speaks írásai egyáltalán nem szerepelnek az elismerni kért tantárgy programjában, segédanyagában vagy ajánlott irodalmában. A két tantárgy szigorú tartalmi összevetésének eredménye lényegében 0\%. A tantárgyfelelős javaslatára azonban a hallgatónak elismerik a „Modern idegennyelvi szakszövegolvasás” tantárgyát, hiszen a képzési programban megjelenő „Modern idegenynyelvi szakszövegolvasás” tantárgy célja az, hogy bepillantást adjon a modern idegennyelvű szakszövegek fordítási kérdéseibe, és megismertesse a hallgatókat a szaknyelvi terminusokkal, amelyet a hallgató elsajátított tanulási eredménye megfelelően kielégít.

3. Egy hallgató informatikus könyvtáros mesterszakon tanul, ahol szeretné elismertetni az „Bevezetés az adatbázis-kezelésbe” tantárgyat (3 kredit). Korábban programtervező informatikus alapképzésben 2 féléven keresztül „Relációs adatbázisok 1-2” tantárgyakat (tárgyanként 2 kredit) teljesítette, gyakorlatokkal és vizsgával. Ugyan alacsonyabb szintről (alapképzésről) származik az elsajátított tanulási eredmény, de teljesítettnek ismerik el a „Bevezetés az adatbázis-kezelésbe” tantárgyat, mert a korábban megszerzett ismerete lefedi és meg is haladja az elismerendő tantárgy követelményét.

4. Erasmus ösztöndíjról visszatért francia nyelv alapszakos hallgató „Középkori francia irodalom” tantárgyat teljesített külföldön a magyar értékelési rendszer szerint elégséges (2) eredménnyel. A hallgató kimenetele előtt rögzítették (Learning Agreement), hogy ezt a tantárgyat sikeres teljesítés esetén a hazai intézmény elismeri, és tanulmányi teljesítményébe beszámítja. A gyengébb eredménytől függetlenül a tanulmányi teljesítménybe való beszámítás meg is történik, a hallgató féléve aktív.

5. Egy had- és biztonságtechnikai mérnöki alapképzésben tanuló hallgató ugyanebben az intézményben, ugyanezen a szakon már tanult 2 félévet, csak egyéni okokból három évvel ezelőtt befejezte a tanulmányait. Újra felvételt nyert, és el kívánja ismertetni többek között a „Katonai számítógépes hálózatok” tantárgyat (4 kredit), amelyet ugyanezzel a névvel és kredittel már tanult és sikeresen teljesített három évvel ezelőtt. A tárgyfelelős javaslata a kreditelismerés elutasítása, mert a katonai informatika annyit fejlődött három év alatt, hogy a korábban teljesített tantárgy tartalma szakmailag teljesen elavult, és már gyökeresen más ismereteken nyújt az elismerni kért tantárgy. A kreditátviteli bizottság elutasítja a kérelmet.

6. Egy hallgató tanár-biológiatanár mesterképzésben vesz részt, és korábban a Magyar Természettudományi Múzeum egyik kutatócsoportjában dolgozott, akik a Duna-Ipoly Nemzeti Park területén élő legyeket tanulmányozták és osztályozták. Erről megfelelő igazolása van a kutatócsoport vezetőjétől. A mesterképzésben nincs olyan konkrét tantárgy, amely kifejezetten a legyekkel foglalkozna, de a képzési programban létezik egy olyan kötelezően választható tantárgycsoport, amelynek a témaköre a rovarok. A tantárgycsoportért felelős oktató (szakfelelős) véleménye az, hogy a komoly munkatapasztalat beleillik a tantárgycsoport témakörébe, ezért javasolja 3 kredittel való elismerését. A kreditátviteli bizottság a megfelelő testület jóváhagyásával egy virtuális tantárgy (KÖV-ROV-000 Rovarok - kreditelismerés, 3 kredit) beiktatásával 3 kredit értékben elfogadja a kreditelismerési kérelmet.

7. Egy amerikanisztika alapszakon tanuló hallgató szeretné a képzésében szereplő „19. századi amerikai történelem" tantárgyat ( 2 kredit) elismertetni az alapján, hogy sportösztöndíjas korában a UCLA-n hasonló tantárgyat tanult. A tantárgyat sikeresen teljesítette 14 kreditet szerezve, amelyről igazolása is van, ám a kaliforniai egyetemen nem ECTS alapú kreditrendszerben történik az oktatás. A tantárgyfelelős véleménye az, hogy az amerikai egyetemen elsajátított tanulási eredmény lefedi az elismerni kért tantárgy követelményeit. A kreditátviteli bizottság elfogadja a kérelmet és elismeri a „XIX. századi amerikai történelem" tantárgyat.

8. Egy teológia alapszakon tanuló hallgató szeretné elismertetni a „Középkori egyháztörténet” című tantárgyat (3 kredit). Egy német főiskolán korábban teljesített egy ezzel azonos nevü tantárgyat. A tantárgyfelelős véleménye az, hogy az egyház egyetemes történetéből megfelelő ismereteket szerzett a hallgató, viszont a speciális és az itthoni képzésben hangsúlyos magyar egyháztörténetből hiányossága van. 

